\title{
Organizational fit or failure : competitive environments, generic and specific strategies in Great Britain and the Netherlands
}

Citation for published version (APA):

Heijltjes, M. G. (1995). Organizational fit or failure : competitive environments, generic and specific strategies in Great Britain and the Netherlands. [Doctoral Thesis, Maastricht University]. Datawyse / Universitaire Pers Maastricht. https://doi.org/10.26481/dis.19950929mh

Document status and date:

Published: 01/01/1995

DOI:

10.26481/dis.19950929mh

Document Version:

Publisher's PDF, also known as Version of record

Please check the document version of this publication:

- A submitted manuscript is the version of the article upon submission and before peer-review. There can be important differences between the submitted version and the official published version of record.

People interested in the research are advised to contact the author for the final version of the publication, or visit the DOI to the publisher's website.

- The final author version and the galley proof are versions of the publication after peer review.

- The final published version features the final layout of the paper including the volume, issue and page numbers.

Link to publication

\footnotetext{
General rights rights.

- You may freely distribute the URL identifying the publication in the public portal. please follow below link for the End User Agreement:

www.umlib.nl/taverne-license

Take down policy

If you believe that this document breaches copyright please contact us at:

repository@maastrichtuniversity.nl

providing details and we will investigate your claim.
}

Copyright and moral rights for the publications made accessible in the public portal are retained by the authors and/or other copyright owners and it is a condition of accessing publications that users recognise and abide by the legal requirements associated with these

- Users may download and print one copy of any publication from the public portal for the purpose of private study or research.

- You may not further distribute the material or use it for any profit-making activity or commercial gain

If the publication is distributed under the terms of Article $25 \mathrm{fa}$ of the Dutch Copyright Act, indicated by the "Taverne" license above, 


\section{ORGANIZATIONAL FIT OR FAILURE}

Competitive environments, generic and specific strategies in Great Britain and the Netherlands 



\section{ORGANIZATIONAL FIT OR FAILURE}

Competitive Environments, Generic and Specific Strategies in Great Britain and the Netherlands

\section{PROEFSCHRIFT}

ter verkrijging van de graad van doctor

aan de Rijksuniversiteit Limburg te Maastricht, op gezag van de Rector Magnificus, Prof. mr M.J. Cohen, volgens het besluit van het College van Dekanen, in het openbaar te verdedigen op vrijdag 29 september 1995 om 16.00 uur

door

Maria Gertrudis Heijlties

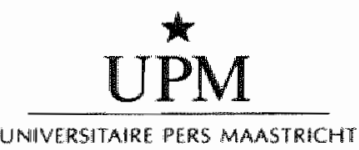




\section{Promotoren:}

Prof. dr A.M. Sorge

Prof. dr A. van Witteloostuijn

\section{Beoordelingscommisie:}

Prof. dr J. Hagedoorn (voorzitter)

Prof. dr W.F.J. Buijink

Prof. dr D.S. Pugh (Open University, United Kingdom)

Heijlijes, Maria Gertrudis

Organizational fit or failure: competitive environments. generic and specific strategules in Great Britain and the Netherlands / Maria Gertrudis Heijltjes. - Maastricht: Uniwersitaire Pers Maastricht. - Ill.

Proefschrift Rijksuniwersiteit Limburg Maastricht. - Met lit. opg. - Met samenvatting in het Nederlands. ISBN $90.5278 * 190-6$

Trefw.: strategisch management / organisatieleer / human resource management.

Cover: Barbe Messing

Production: Datawyse Maastricht/Krips Repro Meppell 


\section{ACKNOWLEDGEMENTS}

During the years that I have been working on this doctoral thesis, I have received support and help from so many people that writing the acknowledgements becomes a risky affair. This is especially so since the support was often not directly related to the content of this thesis, but more to encouraging me to keep on going. I therefore would like to apologize to those that I do not mention by name. Their interest and encouragement was, however, highly valued.

This thesis could not have been completed without the support and dedication of my supervisors, Arndt Sorge and Arjen van Witteloostuijn. I am indebted to both of them for the meticulous review of the draft chapters and the helpful suggestions for improvement. Thanks are also due to John Hagedoorn. Willem Buijink and Derek Pugh for evaluating the final version of this manuscript.

This thesis would be non-existent if it were not for the data on which the research is based. For obtaining the Dutch data, I would like to thank Geert Hofstede, Hein Schreuder, Paul van der Grinten, Rob van Kalmthout, Michiel de Haan and my father for assisting me in gaining access to the companies interviewed. Although for reasons of anonymity $\|$ cannot thank the companies by name, this project could obviously not have been completed without their generous dedication of time and effort. For the British data used in this thesis, I am indebted to the British research team of the International Organizational Observatory. I am especially grateful to Timothy Clark and Geoff Mallory for always patiently answering my numerous questions on their data set and providing me with all the information that I asked for. In analyzing the data, I benefitted from the insightful ideas and comments of Christophe Boone, Bas van Diepen and Bas Koene. Especially the latter deserves a special word of thanks. During the four and a half years in which wo shared an office, he never seemed to get tired of my questions or urges to discuss something with him.

In conclusion, I would like to thank those that provided the most valuable contribution to the eventual completion of this book. First of all my parents who laid the foundation on which 1 could further build and furthermore taught me the importance of discipline and perseverance. Secondly, my sister, who with her stories about the Conservatory and life in Moscow, always put the work on my thesis in its proper perspective. And finally, of course, Michiel who patiently put up with me working on "the book" through weekends and without whose love and support this work would not have been accomplished. I dedicate this book to the four of them.

Mariëlle Heijltjes

May 1995, Maastricht 



\section{CONTENTS}

\section{LIST OF TABLES AND FIGURES}

INTRODUCTION

CHAPTER 1 Underlying Theory: A Contingency Framework 8

1.1 Development of contingency theory 8

1.2 The contingency approach extended to the country lavel 11

1.3 The role of management re-introduced 12

$\begin{array}{lll}1.4 & \text { Different perspectives of fit } & 15\end{array}$

1.5 Empirical studies 18

$\begin{array}{lll}1.6 & \text { Conclusion } & 26\end{array}$

CHAPTER 2 Research Design 28

2.1 The context: the International Organizational Observatory (IOO) 28

2.2 The sample of companies 29

2.3 Data collection method 32

CHAPTER 3 Strategies Pursued in Competitive Environments 35

3.1 The relationship between the competitive environment and generic strategies: a brief literature review 35

3.2 Competitive forces in Great Britain and the Netherlands 37

3.3 The competitive environment in Great Britain and the Netherlands in two dimensions 43

3.4 Formalization of strategy making 47

3.5 Generic strategies pursued in Great Britain and the Netherlands 49

3.6 The relationship between the competitive environment and generic strategy in Great Britain and the Netherlands: different strategies in different environments? 52

3.7 (Strategic) groups based on the environmental dimensions? 54

$\begin{array}{lll}3.8 \text { Conclusion } & 61\end{array}$

CHAPTER 4 The Technological Setting in Relation to the Competitive Environment and Generic Strategies

4.1 Manufacturing technologies, strategies and competitive environment: a brief selection of existing research 63

4.2 Manufacturing technology in British and Dutch firms 65

4.3 Developments in manufacturing technology 68 
4.4 The technological setting and the competitive environment

4.5 The technological setting related to strategies pursued in their respective competitive environments

4.6 Conclusion

CHAPTER 5 Human Resource Management in Relation to the Competitive Environment and Generic Strategies

5.1 Human resource management (HRM) defined

5.2 National culture, the business system and industrial relations

5.2.1 Characteristics of the Dutch and British national culture

5.2.2 The Dutch business system

5.2.3 The British business system

5.3 The business system in relation to the components of Human Resource Management.

5.4 Types of personnel or HRM strategies: does strategic integration and decentralization exist?

5.4.1 Types of personnel or HRM strategies in Dutch food \& drink and chemical companies

5.4.2 Types of personnel or HRM strategies in British food \& drink and chemical companies

5.4.3 Concluding remarks

5.5 Personnel policies and generic strategies: how do they relate?

5.6 The relationship between HRM strategies, the competitive environment and generic strategies

5.7 Conclusion

CHAPTER 6 The Relationship between the Technological Setting, Work Organization and Human Resource Management

6.1 The relationship between production technology and the management of personnel: a brief overview of existing literature

6.2 The impact of advanced manufacturing technology on the production environment

6.3 Advanced manufacturing technology and human resource management: opposing or reinforcing policies?

6.4 Conclusion 
CHAPTER 7 Putting the Pieces of the Puzzle Together: Performance Implications

7.1 Different approaches in performance measurement

7.2 Profiles of the companies: can consistent combinations of competitive environment, generic and specific strategies be found?

7.3 Profilles of the food $\&$ drink and chemical companies: performance implications

7.3.1 Differences in performance between countries and industries

7.3.2 Fit and performance implications

7.4 Conclusion

CHAPTER 8 Summary of Conclusions and Future Research

8.1 Summary of empirical results

8.2 Summary of country differences between Great Britain and the Netherlands

8.3 Summary of industry differences between chemicals and food \& drinks

8.4 Do strategic groups exist within the industries?

8.5 Validity of the questionnaire

8.6 Future research

\section{APPENDICES}

A. Characteristics of British and Dutch companies in the chemical and food \& drink sample

B. Questionnaire items used in analyses.

C. PRINCALS environment variables

D. Cluster analysis

E. Mean scares on developments in the production environment 



\section{LIST OF TABLES AND FIGURES}

Figure 0.1 Outline of the study 3

Figure 1.1 Development to contingency theory 9

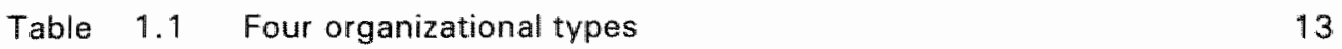

$\begin{array}{llll}\text { Table } & 1.2 & \text { Perspectives and types of fit } & 18\end{array}$

Table 1.3 Sample of empirical studies 1983-1993 19

Table 2.1 Sample of companies in the Netherlands and Great Britain 31

Table 2.2 Research questions and part(s) of the questionnaire used in analysis

Figure 3.1 The relationship between the competitive environment and $\begin{array}{ll}\text { generic strategies } & 36\end{array}$

Table 3.1 Distribution of companies over industries and countries

Table 3.2 Mean rankings of the industries in Great Britain and the Netherlands on the competitive items

Table 3.3 Mean rankings of the chemical and food \& drink industry in Great Britain and the Netherlands on the competitive items

Table 3.4 Mean rankings of the British and Dutch food \& drink industry

Figure 3.2 Object scores labeled by industry classification

Table 3.5 Formal strategic planning in the Netherlands and Great Britain in percentage of companies

Table 3.6 Percentage of companies using theoretical concepts as input for strategic planning

Table

3.7 Percentage of companies systematically collecting data

Table

3.8 Generic strategies pursued in the Netherllands

Table

3.9 Generic strategies pursued in Great Britain

Table

3.10 Generic strategies in different industries

Table

3.11 Kruskall-Wallis test on dimension 1 by strategy pursued

Table

3.12 Kruskal-Wallis test on dimension 2 by strategy pursued

Table

3.13

Strategies in different enviranments

Figure

3.3 Object scores labeled by strategy pursued

Table

3.14 Three clusters in the food \& drink industry based on environmental dimensions

Table 3.15 Three clusters in food \& drinks: means of individual environmental items

Table 3.16 Four clusters in the chemical industry based on environmental dimensions

Table 3.17 Four clusters in chemicals: means of individual environmental items 
Figure 4.1 The rellationship between the technological setting, the competitive enwironment and generic strategies

Table 4.1 Woodward's (1965) classification of production systems

Table 4.2 Distribution of the Dutch and British companies over the different manufacturing technologies

Table 4.3 Distribution of production systems over countries and industries

Table 4.4 Number of companies that implemented advanced manufacturing technologies in the Netherlands and Great Britain

Table 4.5 Significantly different developments in production technology when advanced manufacturing technologies are implemented (in the entire Dutch and British sample)

Table 4.6 Number of companies that implemented advanced manufacturing technologies classified by production system

Table 4.7 Manufacturing technologies in chemical and food \& drink firms further specified

Table 4.8 The relationship between the environmental dimensions and manufacturing technology

Table 4.9 Ranking of refined manufacturing technologies on the environmental dimensions

Table 4.10 Proposed strategy-manufacturing technology relationships

Figure 4.2 Chemical and food \& drink clusters labeled with technology strategy pair

Table 4.11 Three food \& drink clusters labeled by their manufacturing technology-strategy combinations

Table 4.12 Four chemical clusters labeled by their manufacturing technology-strategy combinations

Figure 5.1 The relationship between human resource management, the competitive environment and generic strategies

Table 5.1 National cultures in the USA, Great Britain and the Netherlands

Table 5.2 Working days lost through disputes in 1991 per 1000 employees

Table 5.3 Size distribution in a number of Dutch industries in 1993

Table 5.4 Size distribution in a number of British industries in 1993 in Great Britain bargaining

Table 5.8 The level of strategic integration and decentralization in Dutch firms 
Table 5.9 Level of decentralization in HRM decision-making in British firms

Table 5.10 The level of strategic integration and decentralization in British firms

Table 5.11 The level of strategic integration and decentralization in Dutch and British firms

Table 5.12 Generic strategies assaciated with the levels of strategic integration and decentralization

Figure 5.2 Food \& drink and chemical clusters labeled with HRM strategygeneric strategy pair

Table 5.13 Three food \& drink clusters labeled by their HRM strategygeneric strategy combinations

Table 5.14 Four chemical clusters labeled by their HRM strategygeneric strategy combinations

Figure 5.3 Relationship between generic strategies and HRM strategy types

Figure 6.1 The relationship between the technological setting and human resource management

Table 6.1 Propositions on the relationship between technology and HRM

Table 6.2 Spearman rank order correlation coefficients of the number of automation methods implemented and developments in the production environment

Table 6.3 Significantly different developments in the production environment of large batch and mass production when advanced manufacturing technologies are implemented

Table 6.4 Significantly different developments in the production environment of continuous process production when advanced manufacturing technologies are implemented

Table 6.5 Human resource management systems employed in different advanced large batch and mass manufacturing types

Table 6.6 Human resource management systems employed in different advanced continuous process manufacturing types

Table 6.7 Technology-HRM fit in the chemical and food \& drink companies

Figure 6.2 The relationship between advanced manufacturing technologies and the management of personnel/human resources

Figure 7.1 The relationship between the competitive environment, generic and specific strategies and performance

Table 7.1 Performance measures in a sample of empirical studies 1983-1993 
Figure 7.2 Food \& drink and chemical clusters labeled with strategytechnology-HRM pairs

Table 7.2 Different types of fit in food \& drink cluster 1

Table 7.3 Different types of fit in food \& drink cluster if

Table 7.4 Different types of fit in food \& drink cluster III

Table 7.5 Hypotheses on performance implications in the food \& drink industry

Table 7.6 Different types of fit in chemical cluster 1

Table 7.7 Different types of fit in chemical cluster II

Table 7.8 Different types of fit in chemical cluster III

166

Table 7.9 Different types of fit in chemical cluster IV

167

Table 7.10 Hypotheses on performance implications in the chemical industry

Table 7.11 Return on Sales (ROS) per country

Table 7.12 Return on Sales (ROS) per industry

Table 7.13 Return on Sales (ROS) per industry and country

Table 7.14 ROS per company per food \& drink cluster

Table 7.15 ROS per company per chemical cluster

Table 8.1 Best performing coherent gestalts in the food \& drink industry

Table 8.2 Best performing coherent gestalts in the chemical industry

179

Figure 8.1 Food \& drink and chemical clusters llabeled with strategytechnology-HRM pairs in their respective competitive environments

Table C.1 List of variables used in PRINCALS analysis

Table C.2 Categories and marginal frequencies used in PRINCALS

Table C.3 Eigenvalues of environmentall dimensions

Table C.4 Components loadings of environmental variables

Table D.1 Silhouette of three food \& drink clusters using PAMS

Table D.2 Interpretation of silhouette coefficients according to Kaufman and Rousseeuw (1990)

Table D.3 Agglomeration schedule food \& drink clusters

Table

Dendogram food \& drink clusters

206

Table 0.5 Cluster membership food \& drink companies

206

Table

Silhouette of four chemical clusters

Table

D. 7

Agglomeration schedule for chemical clusters

Table E.1 Mean scores on developments in the production environment 




\section{INTRODUCTION}

In 1972, a grave dating from between 140 and $118 \mathrm{~B} . \mathrm{C}$. was discovered in the Chinese province of Shantung. It contained a more than two thousand years old manuscript of Sun-Tzu's The Art of War (Ames, 1994). This work - the earliest known on strategy and war - contains logic on strategy that is still applicable to today"s organizations. The following statement taken from Sun-Tzu's work encapsulates in essence the theme of this study (Ames, 1994: own translation):

He who knows the enemy and himself, Will in a hundred battles not be in danger: He who not knows the enemy but knows himself, Will sometimes win and sometimes loose; He who neither knows the enemy nor himself, Will be in danger in every battle.

Every organization engages in daily "battles" with competitive forces in its competitive environment, whether these are competitors, suppliers or customers. The decisions which organizations - explicitly or implicitly - make to deal with these forces all contribute to the long-term direction of the organization and thus, taken together, shape their strategies. The success of this strategy will, however, depend on the degree to which all the departments and people working in the organization know where they are heading and on how well they are able to translate this knowledge into the ability to act as a coherent entity. The key to this ability is to know how decisions made in one part of the organization affect other parts.

The study of the relationship between the environment, strategy and structure of organizations still is a central theme in organization theory and strategic managlement today. This book is intended to reveal some additional aspects of this relationship and thus provide organizations with an improved self-understanding, which may eventually increase the number of "battles" won.

\section{Purpose of this study}

This study attempts to gain more insight into the ralationships between the competitive environment, generic strategies, specific strategies regarding manufacturing technology and human resource management (HRM) and performance in a sample of companies in the chemical and food \& drink industries in Great Britain and the Netherlands. Although the relationships between these elements have been a central theme in organization theory and strategic management for approximately 
two decades, there has been little previous research dealing with these relationships in an integral manner. Furthermore, by using a sample consisting of companies in two countries - Great Britain and the Netherlands - and in two industries - chemicals and food \& drinks - it will also be possible to examine inter-country and inter-industry differences. More specifically, this study addresses five questions:

1. What is the relationship between the competitive environment and generic strategies pursued by companies in the chemical and food \& drink industries in Great Britain and the Netherlands? Can a fit between the competitive environment and generic strategy be detected?

2. What is the relationship between the manufacturing technology, competitive environment and generic strategy in the sample of companies studied? Does an "optimal" fit exist?

3. Is human resource management (HRM) used as a management tool to support the different strategies in the different competitive environments? Can a fit between HRM, the competitive environment and strategy be detected?

4. What is the relationship between policies regarding manufacturing technology, work organization and HRM? Can a fit between these elements be established?

5. When the combinations of generic strategy and specific manufacturing and HRM strategies that the companies in our sample employ are viewed in their respective competitive enviranments, do the number of fits established provide an indication of performance?

So, the analysis proceeds from the aggregate level, at which overall generic strategies are discussed, to the more detailed level of specific strategies in two functional areas within the organization. The purpose here is not to determine whether certain functional strategies are more important than others, but merely to study if and how parallel functional strategies link up within the chosen overall strategr. The questions above can be summarized in the framework presented in Figure 0.1. Specific hypotheses concerning the separate relationships are formulated and discussed in each of the empirical chapters.

\section{Outline of the book}

The book follows the order of the five questions stated above closely and is structured in such a way that the empirical chapters can be read relativelly independently. The first two chapters present the underlying theory and research design. Chapter 1 considers the contingency framework on which the empirical analysis is based and reviews empirical studies published in the last ten years. Chapter 2 describes the sample and data collection methods used. The next four chapters focus on the empirical results, although conceptual issues which relate to the specific relationship 


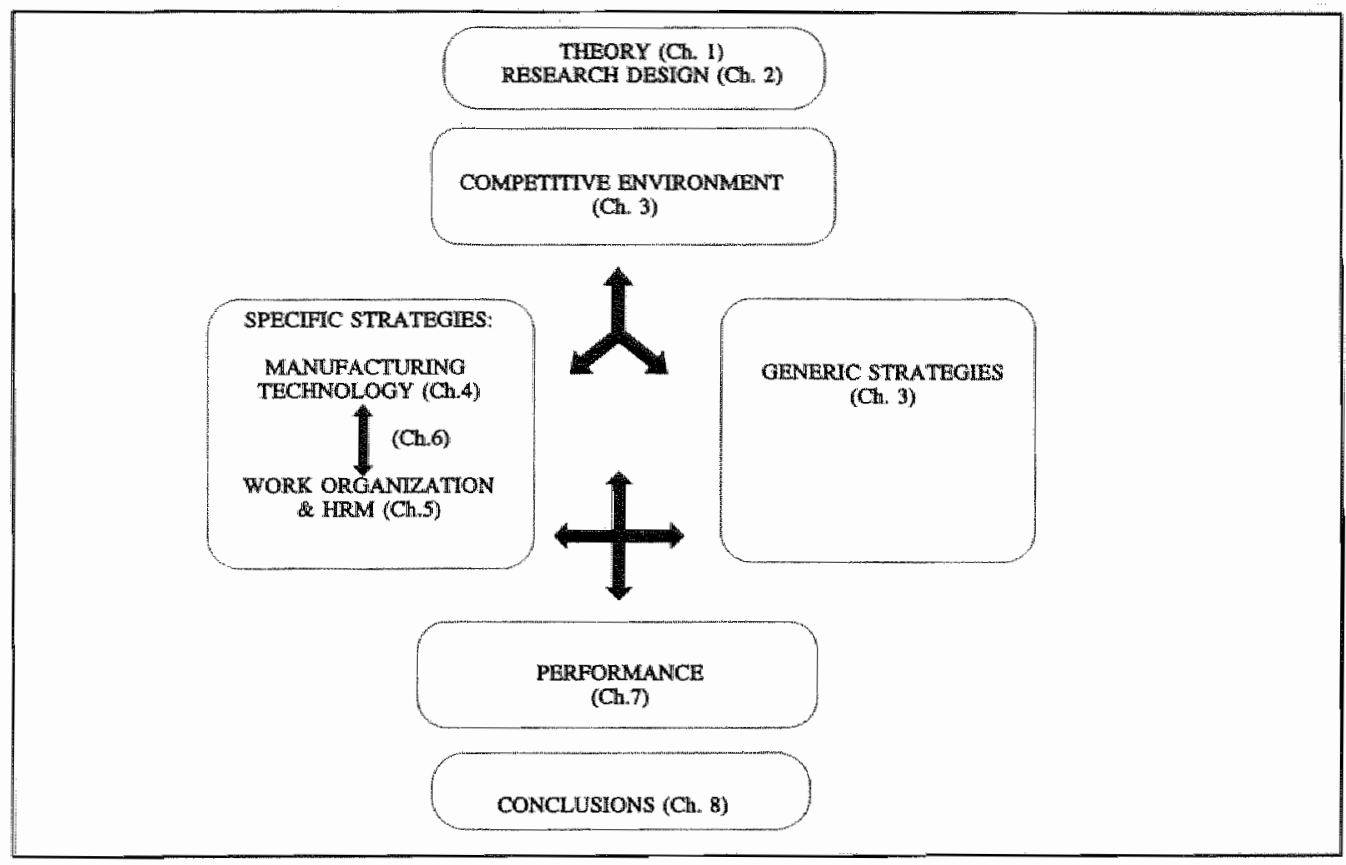

Figure 0.1: Outline of the study

being considered are also integrated in each chapter. As a means of clarification each chapter commences with a figure illustrating the specific relationship being discussed. Chapter 3 examines the relationship between the competitive environment and generic strategies. Chapter 4 analyzes the relationship between competitive environment, generic strategies and manufacturing technology. Chapter 5 focuses on the adoption of human resource management as a supporting management tool, while in Chapter 6 the relationship between the technological setting, work organization and HRM is. investigated. Chapter 7 integrates all the relationships studied to analyze the performance implications. Finally, in Chapter 8 , the results of the study are summarized and suggestions for further research presented.

Before turming to the first chapter, however, the basic concepts of strategy, specific strategies concerning manufacturing technology and HRM, as well as the competitive environment are briefly defined to provide some guidance for the following chapters where these concepts are extensively used.

\section{Strategy defined}

In defining strategy, researchers have made a distinction between the content of strategic action and the process of strategic decision-making. The content of strategy perspective describes the way or ways in which an organization matches its internal 
resources to changes in the environment in pursuit of its long-term objectives (Hatten \& Hatten, 1988; Johnson \& Scholes, 19931. The process of strategy approach emphasizes the way in which strategic decisions are made. Here strategy is viewed as a perceived pattern in a stream of decisions that are made by the people in the organization (Mintzberg, 1988; Stacey, 1993). Since the focus in this book is on the content of strategic decision-making, the process of strategy - although very important - will not be discussed further.

The content of strategy can be divided into three levels: corporate strategy, business strategy and functional strategy (Pearce \& Robinson, 1985). Corporate strategy comprises the choice of where to compete. Ansoff's classic book Corporate Strategy (1965) deals with this problem by identifying specific product-market combimations that are intended to provide guidelines for growth and synergy. Business strategy is more specific and translates corporate strategy to a focus on how to compete in selected product-market combinations. Both Miles \& Snow (1978) and Porter (1980) have made significant contributions to this field by suggesting generic (i.e., non-situation specific) business strategy profiles for firms or business units in specific industries. Finally, functional strategies - or specific strategies - address the actual implementation of corporate and business strategy in functional areas such as manufacturing technology and human resource management. This study focusses on business strategies and two functional strategies in the fields of manufacturing technology and human resource management. These are discussed in more detail in the following section.

Summary: Strategly, in this study, concerns the content of strategy at the business as well as the functional level.

\section{Specific strategies regarding manufacturing technology and HRM defined}

Although other specific strategies may be important to organizational functioning, the technological setting - i.e., the production technology used - and the management of the people performing the different tasks within the organization, are central to the functioning of any manufacturing organization.

Technology can be broadly defined as the tools, techniques and actions used to transform organizational inputs into outputs (Daft, 1992). This definition includes the specific manufacturing technology employed by the organization. The manufacturing technologies considered in this study are classified using a scheme designed by Woodward (1965). Woodward surveyed 100 firms in Great Britain and classified them in three main technolagy groups that differ in technical complexity. The first group, unit- and small batch production, is technically least complex and comprises firms that produce fairly custom made products. The second group, large 
batch and mass-production, contains firms that have long production runs and mainly produce rather standardized parts. Finally the third group, continuous process production, is technically the most complex. The companies in this third group have an entirely automated production process with highly predictable outcomes. In the last two decades, however, companies have received considerably more options to alter their manufacturing process within the three broadly defined technology groups (Jelinek \& Goldhar, 1984\%. Due to new computer-based technologies, like for example Computer Aided Design (CAD) and Computer Aided Manufacturing (CAM), the competitive capabilities of a company can change significantly.

Human Resource Management (HRM) refers to the management of personnel, from the perspective that the people in the organization are viewed as strategic resources who can help the firm obtain a competitive advantage and superior performance Porter, 1985). If employees are viewed as strategic resources, this implies that HRM policies concerning the recruitment and selection of personnel, performance appraisal and compensation as well as training and development, should be in line with the generic strategy pursued (Schuler, 1992). Furthermore, the separate HRM activities should be integrated as efficiently as possible (Fox \& McLeay, 1992).

\section{The competitive environment defined}

Since the environment of an organization contains many different influences, a classification scheme that orders this diversity is necessary. Castrogiovanni (1991) provides such a classification by dividing the environment in five different levels. The most specific is the resource pool level, where the environment is viewed as a stock of specific resources from which the organization acquires what it needs. The resource dependency approach, for example, views the environment in this way (Aldrich \& Pfeffer, 1976). This view of the environment could be operationalized as, for instance. the availability of specific knowledge for a research and development department or the availability of highly skilled technical personnel for the HRM department of a technology-intensive firm. The next most specific level is the sub-environment, which consists of those variables in the environment that influence a specific organizational sub-unit. For example, the functioning of the marketing department will be influenced by a change in advertising codes, which will have no impact on the production department. Similarly, a shift in consumer preferences concerning ice-cream which will affect the division producing ice-cream products without influencing the butter division of the same firm. The third environmental level is the task environment, which combines all the actors in the sub-environments which directly relate to the focal organization. In earlier classifications this was also referred to as the 'organization set' (Evan, 1966) or the 'relevant environment' (Dill, 1958). For an individual organization this environment includes all their customers, suppliers, competitors, etc. The 
aggregation environment extends the task environment to outside agents with which the organization is not in direct contact, but which do have an impact on its functioning. Thus the aggregation environment of an organization includes the industry characteristics. Porter (1980) developed a framework of five forces - the bargaining power of buyers, the bargaining power of suppliers, the threat of substitutes, the threat of potential entrants to the industry and internal rivalry. Knowledge of these five forces provides an insight into the characteristics of the industry and the position of its companies. The last, most comprehensive, level is the macro-environment. Included in the macro-environment is the general cultural, institutional, political and economic context of a society. Sorge (1991), with the societal effect theory, and Whitley (1992) with the business system framework treat the environment at this macro-levell.

In accordance with the focus on strategy at the business and functional level, the environment is primarily interpreted as the task and sub-environment. The data collected on the environment refer to the combination of factors that directly influence the organization (which is the task environment). But since these data were gathered through structured interviews with managers (see Chapter 2 on research design) they are a representation of the managers' perception of the industry comprising those variables that specifically influence the functioning of their unit. In subsequent chapters this sub-environment is referred to as the competitive environment of an organization. In Chapter 5, where the adoption of HRM policies is analyzed, also aspects of the macro-environment are discussed in terms of societall effects and differences in business systems between Great Britain and the Netherlands. The macro-environment is not discussed in other chapters since the point of departure in the societal effect approach is the construction of the social structure which in this study is introduced only in Chapter 5 - as the social structure consists of the configuration of the organization in terms of number and type of employees, the structure and coordination of work, and the qualification and career systems (Maurice, Sorge \& Warner, 1980).

There are of course many more ways to classify the environment. Van Witteloostuijn (1994a), for example, presents two other frameworks in addition to the definition-driven classification outlined above. The first framework is issue-driven, describing the environment in terms of issues that influence the functioning of an organization, such as economic factors, socio-cultural factors, technology and competition. Although these issues are implicitly present in the classification discussed above, they lack specificity for the purpose of this research project in terms of providing a systematic way of unraveling the issues into specific factors important at each level of analysis. The second framework is theory-driven, classifying the environment on the basis of two criteria: i) level of aggregation along a similar framework as Castrogiovanni (1991) and ii) disciplinary perspective. Using this classification one would say that in this specific project insights from economics and sociology are combined to study the environment. Theories based on the economic 
perspective assume rational allocation of means by individual actors. In this study, for example, the competitive strategy theories fit in this perspective. Theories based on a sociological perspective assume that the behavior of a collectivity is determined by its context. Examples will be found in the societal fit theory, and the business system framework on the macro-environment level, as well as elements of contingency theory discussed in Chapter 1.

Summary: The competitive environment, in this study, comprises the subenvironment. The macro-environment, in terms of societal effects and business systems, is introduced in Chapter 5 . 


\section{CHAPTER 1}

\section{UNDERLYING THEORY: A CONTINGENCY FRAMEWORK}

The literature discussed in this chapter sets the stage for the empirical analysis discussed in subsequent chapters. Section 1.1 presents the development of contingency theory and some of its key contributors, and Section 1.2 summarizes two contributions that extend the 'classical' contingency approach to the country level. The role of mamagement is introduced in Section 1.3. In Section 1.4 the concept of fit is discussed and Section 1.5 describes a sample of empirical studies executed within the (neo) contingency approach that were published between 1983 and 1993 . Section 1.6, then, draws some conclusions which serve as an introduction to the research design discussed in Chapter 2.

\subsection{Development of contingency theory}

The notion that an organization"s strategy and structure may vary as a function of its environment lies at the heart of contingency theory. It tries to explain and integrate the earlier classical management approaches on the one hand and the human relations perspective on the other (Scott, 1987a). This development is presented in Figure 1.1 and will be discussed below in more detail. The classical management appraaches developed in the early years of this century emphasized the design features of organizations through scientific analysis of job design (Taylor, 1911) and the development of administrative principles (Fayol, 1916). Efficiency was the driving force behind research in this approach, in which productivity was mainly seen as an engineering problem. Almost parallel to the developments in the classical management approach, another school emerged emphasizing the behavioral structure of the organization. It was therefore named the human relations perspective. The focus of research was on the treatment of the individual in the work environment, and productivity was seen as a social problem. An illustrative example of research in this perspective are the "Hawthorne studies' (Mayo, 1945). In experiments, elements like lighting and working times in the work environment of the workers were manipulated and effects on performance measured. Along similar lines of reasoning, and thus also emphasizing the behavioral structure, Barnard (1938) focused an the entire group of workers stating that for an organization to operate efficiently the organization's goals and the needs of the workers have to be in balance. While research in the human 


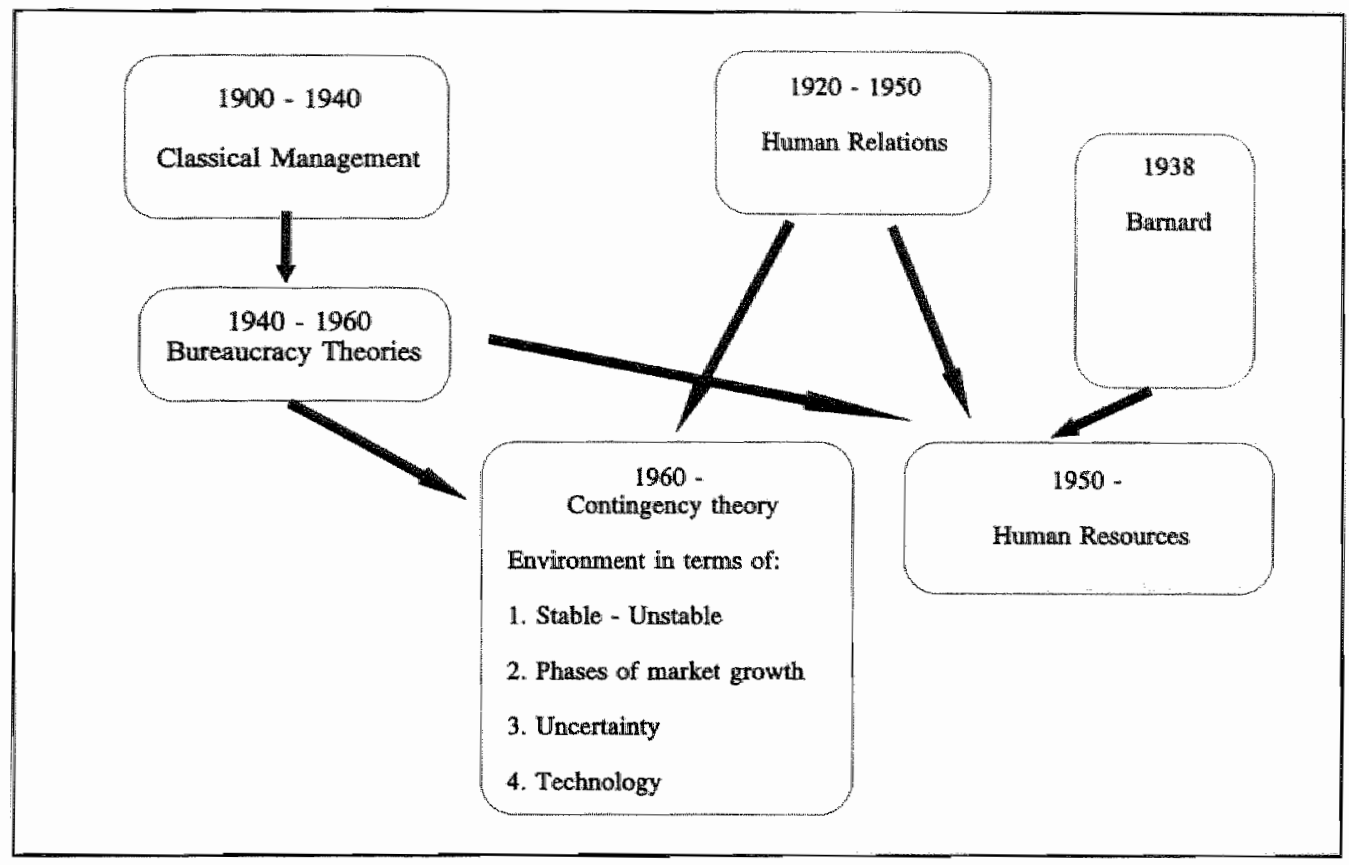

Figure 1.1 Development to contingency theory

relations perspective progressed, Weber's $(1947)^{1}$ work on bureaucracy was associated with the earlier classical approaches.

Research in both the classical management and human relations approaches, operated on the premise of universal principles, in that the 'rules' developed were thought to apply in any situation. In the early sixties these universalistic approaches, and particularly classical management theories, were heavily criticized. When put in practice the theories were thought to stifle the humanity of the employees and to suffer from lack of ability to adapt (Perrow, 1986). The first criticism lead to the development of the human resources perspective which combined insights from classical management and human relations. Job design was still studied "but the individual worker was also considered. This approach is not based on universal principles since it builds on the notion that people should fit the task. The second criticism, on the lack of adaptability resulted in the development of contingency theories in which an organization's strategy and structure vary as a function of its environment. This was the first time that the environment was explicitly considered in the study of organization. The founding fathers of this contingency perspective are Burns \& Stalker (1961), Chandler (1962), Woodward (1965), Lawrence \& Lorsch

Although his work was originally published in 1924, it was not translated into English until 1947 . 
(1967). Thompson (1967). Pugh (1968) and Galbraith (1973). The work of each of these authors will be briefly discussed, under the headings of their various interpretations of the environment.

1. The environment in terms of degree of stability

Burns \& Staker (1961) integrated the views of Barnard (1938) and Weber (1947) by identifying two opposing organizational styles, mechanistic and organic. Mechanistic firms, on the one hand, resemble Weber's ideas on bureaucracy with a distinct division of tasks and a clear hierarchy. These firms operate in a more stable environment. Organic firms, on the other hand, are derived from Barnard's ideas with less formalization and much lateral interaction among co-workers. These organic firms occur in unstable environmental conditions.

2. The environment in terms of market evolution

Chandler (1962) argues that a firm's structure should follow its strategy to obtain efficient results. He identified four phases of growth for American enterprise. The first phase is characterized by rapid expansion and resource accumulation, and the second phase by reduction of unit costs and coordination of functional activities. The third and fourth phase are the decades in which volume expansion and diversification take place. From the organizations he studied the concluded that strategies of volume expansion, product diversification, geographical dispersion and vertical integration need to be supported by an appropriate multi-divisional structure. He was also one of the first to recognize that changes in an organization are the result of choices made by organizations' participants. A notion later defined by Child (1972) as 'strategic choice'. This will be more elaborately discussed in Section 1.3.

3. The environment in terms of uncertainty

Lawrence \& Lorsch (1967) view the organization as a system of interrelated behaviors of people performing tasks. The system is divided into a sales sub-system, a production sub-system and a R\&D sub-system. These sub-systems should be integrated to achieve effective performance of the system. However, conflict emerges because each of these three sub-systems deals with a different sub-environment, which causes variation in the structure of the system, the orientation of its members towards each other and their time and goal orientation. Lawrence and Lorsch conclude that the greater the differences in these four attributes are, the more integration is necessary for the system to function effectively. In other words, the overall performance of the system is related to the congruence of the degree of differentiation among the sub-systems, based on differences in their sub-environments, on the one hand, and the degree of integration, which is based on the requirements of the total environment, on the other. Finally, Galbraith (1973) summarized the assumptions of contingency theory in the maxims that there is no one best way to organize, and that all ways of organizing are not equally effective. To illustrate his point, he links environmental uncertainty with the information-processing capabilities of the organization. The information-processing capabilities are determined by structural 
characteristics of the system, such as rules, departmentalization, hierarchy and dellegation. So the chosen structure has to be aligned with the information-processing requirements of the tasks. These, in turn, are determined by the environmental uncertainty surrounding these tasks.

\section{The enviromment in terms of technology}

The first to investigate the relationship between manufacturing technology, structural characteristics and dimensions of management style was Woodward (1965). She identified three basic technology groups: small batch and unit production, large batch and mass production and continuous process production. Each type of technology is associated with different structural characteristics. In firms where technology and structure are complementary, performance is higher. Thompson (1967) also associated the type of technology, defined as the differing interdependence of work units, with the structure of the organization. The technology employed helps to predict the structural features of three levels within organizations: the technical level, the managerial level and the institutional level. He argues that the need to adapt to the environment depends on the level within the organization. The technical level will be most protected from environmental changes, while the institutional level should be most responsive to this turbulence. Finally, Pugh and the Aston Group (1968) were among the first researchers to test the relationship between the structure of organizations, their size, the technology used and dependence on other organizations, using large samples of companies.

\subsection{The contingency approach extended to the country level}

Sorge (1991) attempts to extend the contingency framework to the country level by incorporating a sccietal effect. He hypothesizes that societal differences in organizing. generating human resources and the pursuit of different business strategies are reciprocally related. So, in different societies different organizational forms and human resource practices emerge, because economic niches and business strategies are different land vice versal. To test this hypothesis he examines firms in specific manufacturing industries in France, Germany and Great Britain. He concludes that the interaction of industry and societal profiles implies continuous adaptation of the business strategy, organization and human resources of the specific firm. Furthermore, performance in an industry or sector depends on the correspondence between this company specific and the societal profile (independent of the specific task environment of the organization). Thus in the societal effect approach the organization is seen as a reflection of the macro-environment, while in "classical" contingency theory the technical and economic characteristics of the organizations mirror features of the taskenvironment. A similar approach is taken by Whitley (1992), who also points out that the effectiveness of a particular form of organization is institutionally determined. He 
Uses the business system concept to investigate this further. Business systems are defined as particular arrangements of hierarchy-market relations which become institutionalized, such as the nature of the firm, the market organization and the authorative coordination and control systems. Therefore, relationships between environment, structure and strategy have to be examined in their specific business system context instead of as a set of correlations applying in a more universal fashion. Whitley 11992), however, does not explicitly examine whether institutional factors have a larger impact on performance than more universal task environment factors as Sorge suggests.

An example of research conducted along these lines is provided by Porter (1990). He developed a framework consisting of the firm's strategy, structure and rivalry, the factor conditions, the demand conditions and the related and supporting industries in a country. These country-specific features determine whether an industry and its firms, will be successful. Maurice, Sorge \& Warner 11980 ) also provide an example of how processes of educating, training, recruiting and promoting that are institutionally determined, lead to different shapes of organizations in different countries.

\subsection{The role of management re-introduced}

The founders of the contingency approach discussed in Section 1.1 implicitly assumed a unidirectional influence of the environment on the organization. So, a necessary condition for survival is the adaptation of the organizational structure to the environment. Neo-contingency theory modifies this deterministic assumption by introducing the idea that there is a mutual interaction between environmental demands and organizational characteristics because organizations can, by their own choices, influence their environment to a certain extent (Child, 1972; Schreyögg, 1980). This notion is further develaped by Hrebiniak \& Joyce (1985), who argue that adaptation of the organization through determinism and through voluntarism are not opposite ends of a single continuum. Determinism, or external selection, means that environmental factors, such as the structural characteristics of an industry or government regulations, force the organization to adapt. If it continuously fails to do so, it will ultimately seize to exist. Voluntarism or organizational choice implies that the organization adapts to changes in the environment by its own choice, to create new opportunities. Hrebiniak \& Joyce specifically focus on the interaction of environmental selection and organizational choice, since the interactive nature of the organization and the environment is critical in the adaptation process. Four organizational types are defined on the basis of this interaction: 1) organizations for which enwironmental selection is high and organizational choice is law, 2) organizations for which both environmental selection and organizational choice are high, 31 organizations for which environmental 
selection is low and organizational choice is high and, finally, 4 ) organizations for which both environmental selection and organizational choice are low. These four types are presented in Table 1.1.

In quadrant I, where environmental selection is high and organizational choice is low, the behavior of the companies is mainly determined by the environment. Examples are a division or business unit of a chemical company that praduces salt or hydrocarbons, or a butter factory. These are all bulk products with externally determined market prices and hardly any possible product differentiation. These companies have no strategic options other than to produce as efficiently as possible following a cost leadership (Porter, 1980) or defender (Miles \& Snow, 1978) strategy. One theoretical contribution using assumptions which would fit this quadrant is organizational ecology, a branch of organization studies. The ecologists argue that organizations are characterized by relative inertia: they react very slowly to changes in the environment and thus suffer from lack of strategic choice. This is due to unpredictability of future environmental states, political decision-making and the difference between intentions and outcomes (Hannan \& Freeman, 1989).

\begin{tabular}{|c|c|c|}
\hline Four organizational types & High selestion & Low selection \\
\hline High chorice & $\begin{array}{l}\text { Quadrant II } \\
\text { Practice: } \\
\text { Competitive market with differentiated } \\
\text { products } \\
\text { Theory: } \\
\text { Extension of organizational ecology }\end{array}$ & $\begin{array}{l}\text { Quadrant III } \\
\text { Practica: } \\
\text { Non-regulated monopoly or } \\
\text { oligopoly } \\
\text { Theory: } \\
\text { Stratagic choice }\end{array}$ \\
\hline Low choice & $\begin{array}{l}\text { Quadrant I } \\
\text { Practice: } \\
\text { Competive market with generic or } \\
\text { butk products } \\
\text { Theory: } \\
\text { Organizational ecology }\end{array}$ & $\begin{array}{l}\text { Quadrant IV } \\
\text { Practice: } \\
\text { Heavily ragullated market } \\
\text { Theary: } \\
\text { Unsititutionat theory }\end{array}$ \\
\hline
\end{tabular}

\section{Table 1.1: Four organizational types}

The companies in quadrant ll find themselves in similar circumstances. In this quadrant environmental selection is also high but the organizations have considerably more choice in determining their destiny. This is the case in a competitive market in which organizations can determine their own course of action, for example by product differentiation. This implies that a wide array of strategic options is available here, even combinations of different generic strategies (Hill, 1988; Murray, 1988). Examples are firms in the food $\&$ drink industry that produce differentiated products like candy or desserts or producers of specialty chemicals in the chemical industry. A theoretical contribution that fits into this quadrant is an extension of the traditional organizational ecology framework. It argues for a balanced co-existence of inertia and flexibility 
(Boone \& Van Witteloostuijn, 1995). In this view, part of the organization is subject to relative inertia and incremental adjustments, while the other part must be flexible and lead the organization into new unexplored avenues. Elements of this reasoning can already be detected in Thompson's (1967) work on technology and structure. Although he did not say so in as many words, he argued that the need to adapt to the environment depends on the level within the organization (see also Section 1. 1). There are parts within the organization that are protected from environmental changes (the technical levell and parts that need to be open to change and explore new possibilities (institutional levell.

In quadrant III, organizational choice is also high but the power of the environment to determine the organizations' actions is much lower. Examples of companies operating in this situation are the Dutch Post and Telecom company or the privatized Dutch railways. Because the market in both cases used to be protected and the costs of entry are extremely high, environmental selection is low. But because they are privatized companies now, they have considerable freedom in choosing their strategy. An example of theory that builds on the assumption that the management of organizations can deliberately choose which actions the organization will or will not take when the environment changes, is strategic choice (Child, 1972). Child (1972) emphasizes that an organization changes because of choices made by its members. His reasoning is therefore the opposite of the assumptions underlying organizational ecology as discussed above. Another theory fitting in this quadrant is top management studies, which examines the relationship between strategic choices and composition of the top management team (Boone, de Brabander \& Van Witteloostuijn, 1993).

Finally, in quadrant IV, both environmental selection and organizational choice are low. Companies operate under such conditions when the market is heavily regulated by government(s). Examples in the Netherlands include the sugar producing companies and electrical power suppliers. The prices and sales volumes for these companies are set by the government and there is no possibility of new competition entering. Because of the 'protected' nature of the markets, there is little risk that these companies will cease to exist. However, the regulations also limit the company"s strategic choices. Choices are, as in quadrant I, restricted to the similar strategies of cost leadership or defender. The assumption of low environmental selection and low arganizational choice is reflected in institutional theory. Although there are many different theoretical approaches within institutional theory, they all emphasize the ability of the organization to adapt and view managerial actions as guided by something else, like values or taken for granted assumptions, than conscious strategic choice (Scott, 1987b). One example of such an approach is the description of three mechanisms through which institutional isomorphic change occurs by DiMaggio \& Powell (1983). The first mechanism is coercive isomorphism which results from political pressures like legal restrictions or other legitimized sources of authority. Mimetic isomorphism develops because of standard responses to uncertainty, such as 
the copying of behavior of other organizations. And, finally, normative isomorphism stems from professionalization due to formal education and the existence of professional networks.

(Neo) contingency theory is consistent with more than just one of the quadrants discussed above. It assumes a fit between the environment and the organization, but this fit can be established in two ways. Either the environment selects organizations so that only those organizations that best match their environment survive, or organizations are designed to match their environment by conscious or unconscious choices made by management.

\subsection{Different perspectives of fit}

A key assumption underlying (nea)-contingency theory is that for an organization to perform effectively, a fit between environmental (in the broadest sense), structural and strategic characteristics has to be established. Despite the fact that this might seem a logical assumption, the concept of fit in contingency approaches has been widely debated le.g. Schoonhoven, 1981; Venkatraman \& Camillus, 1984; Drazin \& Van de Ven, 1985; and Venkatraman, 1989). In particular, it is necessary to state explicitly which perspective of fit has been adopted and how it is conceptualized. Venkatraman \& Camillus (1984) present six different perspectives of fit in strategic management, based on two dimensions. The first dimension, the conceptualization of fit distinguishes between approaches that focus on the content of fit and views that concentrate on the process of aligning structure, environment and processes of strategy-making. The second dimension defines the domain of fit: that is, whether the emphasis is on the fit between internal elements and strategy, external elements and strategy or a combination of both. The six perspectives will be briefly discussed below along with some examples of empirical studies fitting in these schools.

The strategy formulation school emphasizes the alignment between the environment and strategy. Studies conducted within this school are rooted in industrial organization theory, in which the (market) structure-conduct-performance (SCP) paradigm is of central importance (Scherer \& Ross, 1990). Traditionally, however, the emphasis in this paradigm was more on the (market structure-performance relationship than on the conduct of firms. Conduct was viewed as determined by market structure ${ }^{2}$. A well-known example derived from industrial organization theory and fitting in the strategy formulation school is the strategy research by Porter (1980). He identified five key competitive market forces - internal rivalry within the industry. the threat of potential entrants, the threat of substitutes and the bargaining power of

2 Note, however, that much modern industrial organization theory recognizes the reciprocal conditions in a SCP-setting. For an overview, see Tirole (1988) and Van Witteloostuijn (1994b). 
buyers and suppliers - which influence the choice of a competitive, generic, strategv. The second perspective, known as the strategy implementation school, addresses the issue of matching organizational and structural elements to strategy. An example is the strategy-structure fit as discussed by Chandler (1962). More recent examples include a study relating strategic types and distinctive marketing competencies to performance (Conant, Mokwa \& Rajan Varadarajan, 1990) and a study by Govindarajan \& Fisher (1990) relating control system and resource sharing to competitive strategy and performance. The integrated formulation-implementation school combines the perspectives of the previous two schools, and thus devotes attention to environmental aspects as well as structural aspects in relation to strategy. Miles \& Snow's work $(1978,1984)$ on the relationship between the generic strategies of defender, analyzer, prospector and reactor, on the one hand, and the alignment with the environment and the internal structures and management processes on the other, fits into this school. Many of the empirical studies performed by Miller (1987b, 1988) are also clear examples of the integrated approach.

All three of these schools address the content of fit. The following three schools emphasize the process of fit. The interorganizational (strategy) networks school takes relationships with other organizations into account when considering the competitive environment. The environment-strategy fit is viewed from this interorganizational perspective. Resource dependency theory is closely related to this school (Aldrich \& Pfeffer, 1976). The central theme of this theory is that organizations need to engage in relationships with other organizations to ensure the supply of required resources and services. These interdependencies are based on differentiation, interorganizational division of labor and decisions made by management. The effect and importance off strategic choice, which is implicitly acknowledged in the interorganizational networks school, is the focus of attention in the strategy process school ${ }^{3}$. This strategy process school looks at the pattern of interaction between internal organizational elements and strategy. It also assumes that this pattern of interaction is established by conscious cholices made by management, rather than being determined by contingency forces (Child, 1972). One recent example of an empirical study fitting in this school is the attempt to measure the direct and indirect effect of three strategic sense-making activities (scanning, interpretation and actions) of managers on performance (Thomas, Clark \& Gioia, 1993). The sixth school finally, is the overarching "gestalt" school, where a profile of environmental, structural and strategy elements is constructed and studied instead of the individual elements in relation to each other. The underlying rationale here is that relationships cannot be divorced from their context, so it does not make much sense to investigate only relationships between a few structural, environmental and strategic variables without examining their interdependence (Miller,

3 In the article by Venkatraman and Camillus (1984) this perspective is called the strategic choice school. However, to avoid confusion with other uses of strategic choice, the original name has been changed here. 
1986). One example fitting in this school is a study by Herbert \& Deresky (1989), in which they empirically develop a typology of the content of generic strategies.

Even within the six differing perspectives presented above, 'fit' between the different elements can be tested in many different ways. One way to measure fit is to take a systems approach (Drazin \& Van de Ven. 1985). In this approach fit is the internal consistency of multiple contingencies and multiple structural characteristics. Deviations from the ideal profile affect performance negatively. Venkatraman (1989) distinguishes three possible measures within the systems approach : fit as profile deviation, in which adherence to a specified profile with a high level of environmentstrategy coalignment determines performance, fit as covariation, in which internal consistency in resource allocations determines performance, and finally fit as 'gestalt', in which the internal congruence among a set of variables differs for high and low performing organizations. Venkatraman \& Prescott (1990) explicitly use a profile deviation definition of fit in their empirical study on the coalignment of environment with strategy. They find negative performance implications if deviations from icleal patterns of strategic resource deployments occur. Fit as covariation is implied in the empirical study by Dess \& Davis (1984), in which factor analysis reveals that Porter's (1980) generic strategies are a collection of internally consistent competitive methods. A subsequent cluster analysis then shows that these generic strategies form distinct clusters that are rellated to performance. An example of an empirical study where, although not explicitly stated by the author, fit is interpreted as 'gestalt', is the research into indicators of strategic performance by Chakravarthy (1986). His sample is divided into 'excellent' organizations and 'not excellent' organizations. He assumes, by studying performance characteristics only, that the excellent organizations are well adapted and therefore more successful without specifically examining the configuration of environment, strategy and structure elements that could cause this better alignment. The not excellent organizations should perform worse and therefore suffer from a lack of internal congruence. Fit can also be measured using a selection or interaction approach (Drazin \& Van de Ven, 1985). The selection approach, or fit as matching (Schoonhoven, 1981 and Venkatraman, 1989\%, defines fit as the congruence or match between strategy and structure, or between environment and strategy, or between structure and environment. This approach deals mainly with bivariate relationships. Examples of studies which treat fit as matching can be found in research by Miller (1988), in which he examines the relationship between Porter's (1980) business strategies, the environment, structure and performance, and research by White (1986), in which the relationship between Porter's (1980) generic strategies, organizational context and performance is examined. The interaction approach, or fit as moderation (Venkatraman, 1989), looks at interactive effects between the strategy, environment and structure variables. So, besides the direct effect that the environment and structure separately have on strategy there is also a multiplicative effect (Schoonhoven, 1981) on strategy. Powell (1992) uses fit as moderation to test 
hypotheses, based on the work of Lawrence \& Lorsch (1967), regarding the relationship between environment, structure and strategy-making. Using the interaction method enables him to investigate the joint effect of any two alignment variables (for example, environmental stability and strategy-making) on profitability. Finally, fit as mediation (Venkatrarrian, 1989) measures the direct effect of, for example, environment on strategy and the indirect effect of, for example, environment via structure on strategy. Am example of an empirical study in which fit can be interpreted as mediation is the indirect effect of strategic group structure via conditions of rivalry on firm performance (Cool \& Dierickx, 1993).

Summary: Fit and the empirical studies applying a concept of fit can be classified into six different perspectives. Furthermore, the measurement of fit employed can also be divided into six types. Table 1.2 provides a summary.

\begin{tabular}{|c|c|c|c|}
\hline \multicolumn{2}{|c|}{ Perspective of fit (Venkatraman, 1984) } & \multicolumn{2}{|c|}{ Type of fit i Wenkatraman. 1989} \\
\hline 1 & Strategy formulation school & 1. & Fit as profile deviation \\
\hline 2. & Strgtegy implementation schoo: & 2. & Fit as covariation: \\
\hline 3. & Integrated formulation and implementation school & 3. & Fit as 'gestalt" \\
\hline 4. & Intterorganizational istrategy networks school & 4. & Fit as matching \\
\hline 5. & Strategy process school (strategic choice school) & 5. & Fit as mediation \\
\hline 6. & Overarching gestalt school & 6. & Fit as moderation \\
\hline
\end{tabular}

Table 1.2: Perspectives and types of fit

\subsection{Empirical studies}

Since the (neo)-contingency approach is one of the most important paradigms in organization and strategic management research, a large number of empirical studies has been conducted within this framework. Some have already been briefly described in the previous section. Table 1.3 below presents in alphabetical order 37 representative studies, of which 34 are empirical, classified by perspective and type of fit. They were published between 1983 and 1993. The non-empirical studies of Kotha \& Orne (1989). Milliman, Von Glinow \& Nathan (1991) and Parthasarthy \& Sethi (1992) are included for their specific contribution to the understanding of fit and manufacturing structure, fit and HRM and fit and technological environment, respectively. 


\begin{tabular}{|c|c|c|c|c|c|}
\hline Author & $\begin{array}{l}\text { Perspective } \\
\text { rVonkatraman, } \\
\text { 1984 }\end{array}$ & Theme & $\begin{array}{l}\text { Twpe of fit } \\
\text { Wenkatramis. } \\
1989 \text { ! }\end{array}$ & Sampores & Results \\
\hline $\begin{array}{l}\text { Chakgawarthy } \\
(1986)\end{array}$ & $\begin{array}{l}\text { Overarching } \\
\text { gestalt schoof }\end{array}$ & $\begin{array}{l}\text { Identification of } \\
\text { measures of } \\
\text { strategic } \\
\text { pertormance that } \\
\text { distinguish wel h- } \\
\text { adapted from mal } \\
\text { adlapted firms }\end{array}$ & Fit as gestalt: & $\begin{array}{l}14 \text { firms in US } \\
\text { computer } \\
\text { industry }\end{array}$ & $\begin{array}{l}\text { The quatiny of a firm"s } \\
\text { transformations and } \\
\text { the satisfaction of all } \\
\text { stakehoiders aro } \\
\text { important measures } \\
\text { of sto ategic } \\
\text { performance. } \\
\text { Tradifional measures } \\
\text { appear inadequate }\end{array}$ \\
\hline $\begin{array}{l}\text { Conant. } \\
\text { Makwa \& } \\
\text { Rajan } \\
\text { Maradarajan } \\
119901\end{array}$ & $\begin{array}{l}\text { Strategy } \\
\text { implementation } \\
\text { school }\end{array}$ & $\begin{array}{l}\text { Relationship } \\
\text { batween strategin } \\
\text { types, distinctive } \\
\text { marketing } \\
\text { competemcies and } \\
\text { organizational } \\
\text { performance }\end{array}$ & $\begin{array}{l}\text { Fit as } \\
\text { matching }\end{array}$ & $\begin{array}{l}406 \\
\text { organizations } \\
\text { in American } \\
\text { health } \\
\text { maintenance } \\
\text { industry }\end{array}$ & $\begin{array}{l}\text { Matkething } \\
\text { competencies of } \\
\text { prospectors are } \\
\text { superior to those of } \\
\text { analyzers. defenders } \\
\text { and reactors. } \\
\text { Performance is equal } \\
\text { for the first three } \\
\text { strategies, but worse } \\
\text { for reactors }\end{array}$ \\
\hline $\begin{array}{l}\text { Cool \& } \\
\text { Dierickx } \\
(1993 \mid\end{array}$ & $\begin{array}{l}\text { Strategy } \\
\text { formulation } \\
\text { school }\end{array}$ & $\begin{array}{l}\text { 1) Are there } \\
\text { meaningful } \\
\text { differances in } \\
\text { effects of within } \\
\text { group iriwalry on firm } \\
\text { performance? } \\
\text { 2) Are these } \\
\text { comditions of rivalry } \\
\text { driven by strategic } \\
\text { group stiructure? }\end{array}$ & $\begin{array}{l}\text { Fit as } \\
\text { mediation }\end{array}$ & $\begin{array}{l}\text { US pharma } \\
\text { ceuticnat } \\
\text { indistry }\end{array}$ & $\begin{array}{l}\text { Declining indistry } \\
\text { profitability is strongly } \\
\text { associated with } 11 \\
\text { increasing riwalry } \\
\text { which changes the } \\
\text { stratergic group } \\
\text { structure and } 2 \text { f a } \\
\text { shift from within } \\
\text { group rivatry to } \\
\text { between graup rwairy }\end{array}$ \\
\hline $\begin{array}{l}\text { Dess \& Davins } \\
119841\end{array}$ & $\begin{array}{l}\text { Strategy } \\
\text { formulation } \\
\text { schooll }\end{array}$ & $\begin{array}{l}\text { Relationship } \\
\text { between generic } \\
\text { strategies, strategic } \\
\text { group membership } \\
\text { and perfommanci }\end{array}$ & $\begin{array}{l}\text { Fit asi } \\
\text { covariation }\end{array}$ & $\begin{array}{l}28 \text { non } \\
\text { diversified } \\
\text { firms in the } \\
\text { US paint and } \\
\text { allied products } \\
\text { industry }\end{array}$ & 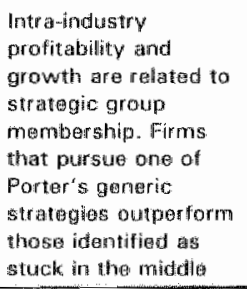 \\
\hline $\begin{array}{l}\text { Dvir, Seglev } \\
\text { shenhar } \\
19993\end{array}$ & $\begin{array}{l}\text { Strategy } \\
\text { implementation } \\
\text { school }\end{array}$ & $\begin{array}{l}\text { Relationship } \\
\text { between inveskmemt } \\
\text { in technological } \\
\text { progress of } \\
\text { defenders, analyzers } \\
\text { and prospectors ard } \\
\text { their short and } \\
\text { long-term swecess }\end{array}$ & $\begin{array}{l}\text { Fit as } \\
\text { mistching }\end{array}$ & $\begin{array}{l}180 \text { firms in } \\
\text { flectronic and } \\
\text { computer } \\
\text { industry. } \\
\text { Couintyy inot } \\
\text { specified }\end{array}$ & 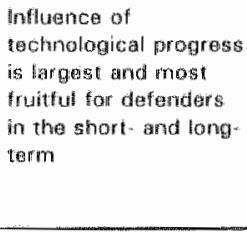 \\
\hline $\begin{array}{l}\text { Gowindaraian } \\
(1988)\end{array}$ & $\begin{array}{l}\text { Strategy } \\
\text { implementation } \\
\text { school }\end{array}$ & $\begin{array}{l}\text { The relationstip } \\
\text { between } \\
\text { competitive } \\
\text { strategy. } \\
\text { administratiwe } \\
\text { rmechanisms and } \\
\text { their interactive } \\
\text { effect on } \\
\text { performance }\end{array}$ & $\begin{array}{l}\text { Fit ass } \\
\text { modiaration } \\
\text { and tit as } \\
\text { profile } \\
\text { deviation }\end{array}$ & $\begin{array}{l}\text { 24. US firms } \\
\text { on Forturie } \\
500 \text { hist in } \\
\text { various } \\
\text { industries }\end{array}$ & 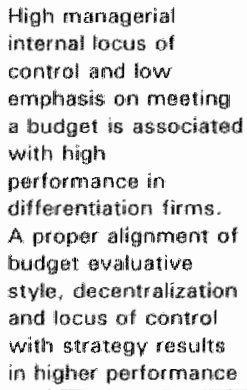 \\
\hline
\end{tabular}




\begin{tabular}{|c|c|c|c|c|c|}
\hline Author & 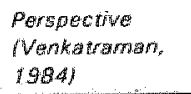 & Theme & $\begin{array}{l}\text { Type of fit } \\
\text { IVenkat traman. } \\
\text { 1989) }\end{array}$ & Sample & Resuhts \\
\hline $\begin{array}{l}\text { Govindigratan } \\
\text { Fisher } \\
\text { It990) }\end{array}$ & $\begin{array}{l}\text { Strategy } \\
\text { implementation } \\
\text { school }\end{array}$ & $\begin{array}{l}\text { Relationship } \\
\text { between control } \\
\text { system, rescurce } \\
\text { shating between } \\
\text { SBU, and other } \\
\text { units, competiture } \\
\text { strategy and } \\
\text { performance }\end{array}$ & $\begin{array}{l}\text { Fit as } \\
\text { matching and } \\
\text { fit ass } \\
\text { rnoderation }\end{array}$ & $\begin{array}{l}24 \text { US dirnss } \\
\text { on Fortune } \\
500 \text { int in } \\
\text { various } \\
\text { industries }\end{array}$ & $\begin{array}{l}\text { A lowwcost strategy is } \\
\text { associated with } \\
\text { output control and } \\
\text { high resource sharing } \\
\text { and a differentiation } \\
\text { strategy with } \\
\text { behavior control and } \\
\text { high resource sharing }\end{array}$ \\
\hline $\begin{array}{l}\text { Habib \& } \\
\text { Vicilor (1991) }\end{array}$ & $\begin{array}{l}\text { Strategy } \\
\text { implementation } \\
\text { school }\end{array}$ & $\begin{array}{l}\text { Relationship } \\
\text { between sitratiegy. } \\
\text { structure and } \\
\text { performance in } \\
\text { MNCs }\end{array}$ & $\begin{array}{l}\text { Fit as } \\
\text { matching and } \\
\text { fit as } \\
\text { moderation }\end{array}$ & $\begin{array}{l}\text { 144 US basad } \\
\text { MNCs, } 72 \text { in } \\
\text { services and } \\
72 \text { in } \\
\text { manufacturing }\end{array}$ & $\begin{array}{l}\text { MNiCs choose } \\
\text { struciure in line with } \\
\text { strategy. Strategy- } \\
\text { structure fit has no } \\
\text { impact on } \\
\text { performance of } \\
\text { service MNCs. Mixed } \\
\text { results were found in } \\
\text { manufacturing MNCs }\end{array}$ \\
\hline $\begin{array}{l}\text { Hambrick } \\
\text { (1983al }\end{array}$ & $\begin{array}{l}\text { Strategy } \\
\text { formulation } \\
\text { sehool }\end{array}$ & $\begin{array}{l}\text { Development of a } \\
\text { typology of mature } \\
\text { industrial product } \\
\text { ervironments }\end{array}$ & $\begin{array}{l}\text { Typobogy ciar } \\
\text { be used for } \\
\text { testing fit as } \\
\text { gestalt }\end{array}$ & $\begin{array}{l}200 \text { firms in } \\
\text { PUMS data } \\
\text { base }\end{array}$ & $\begin{array}{l}\text { Cluster analysis yieids } \\
\text { elight enwironmental } \\
\text { types in which } \\
\text { sfrategies could be } \\
\text { fested for their } \\
\text { elfectiveness }\end{array}$ \\
\hline $\begin{array}{l}\text { Hambrick } \\
\text { 1983b) }\end{array}$ & $\begin{array}{l}\text { Strategy } \\
\text { formulation } \\
\text { schonol }\end{array}$ & $\begin{array}{l}\text { How is high } \\
\text { performance } \\
\text { achieved in two } \\
\text { types of industry } \\
\text { environments: in the } \\
\text { disciplined capital } \\
\text { goods makers and } \\
\text { in the aggressive } \\
\text { makers of complex } \\
\text { cepittal goods? }\end{array}$ & Fut as gestalt & $\begin{array}{l}164 \text { firms in } \\
\text { PUMS data } \\
\text { base }\end{array}$ & $\begin{array}{l}\text { In each ind ustry } \\
\text { enwironment three } \\
\text { high profit clusters. } \\
\text { were identified closely } \\
\text { resemble Porter's } \\
\text { types. Also two low } \\
\text { profit clusters were } \\
\text { identified for each } \\
\text { environment. lt is } \\
\text { shown that different } \\
\text { high profit strategies } \\
\text { are possible within } \\
\text { one industry }\end{array}$ \\
\hline $\begin{array}{l}\text { Herbert \& } \\
\text { Doresky } \\
(1999)\end{array}$ & $\begin{array}{l}\text { Overarching } \\
\text { gestialt school }\end{array}$ & $\begin{array}{l}\text { Empirical } \\
\text { development of a } \\
\text { typology of generic } \\
\text { strategies and the } \\
\text { content of mach } \\
\text { type }\end{array}$ & Fit as gastalt & $\begin{array}{l}\text { 34. Canadian } \\
\text { firms in } \\
\text { vartious } \\
\text { industres }\end{array}$ & $\begin{array}{l}\text { Six different strategy } \\
\text { profiles were } \\
\text { identifted. A profile } \\
\text { consists of a } \\
\text { consistent and } \\
\text { interrelated pattern of } \\
\text { actions }\end{array}$ \\
\hline $\begin{array}{l}\text { Kothat Orne } \\
\text { 11989) }\end{array}$ & $\begin{array}{l}\text { Stratery } \\
\text { imphementation } \\
\text { sonoof }\end{array}$ & $\begin{array}{l}\text { To develop a } \\
\text { conceptual } \\
\text { framework for } \\
\text { considering the fit } \\
\text { between structure, } \\
\text { strategy, technology } \\
\text { and performance in } \\
\text { manufacturing } \\
\text { competitiveness }\end{array}$ & Not applicable & Not applicable & $\begin{array}{l}\text { A conceptual } \\
\text { framewark is } \\
\text { developed that links } \\
\text { Porter's (1980) } \\
\text { gerweric strategles to } \\
\text { manufacturing } \\
\text { structure in three } \\
\text { dimensions: processi } \\
\text { structure complexity. } \\
\text { product line } \\
\text { complexity and } \\
\text { organizational sicope }\end{array}$ \\
\hline
\end{tabular}




\begin{tabular}{|c|c|c|c|c|c|}
\hline Atrthor & $\begin{array}{l}\text { Perspective } \\
\text { (Wenk atramant } \\
\text { (984) }\end{array}$ & Themes & $\begin{array}{l}\text { Type of fit } \\
\text { Wenks rraman. } \\
\text { 1909) }\end{array}$ & Sample & Resulps \\
\hline $\begin{array}{l}\text { Moked, Rajan } \\
\text { Varadarajan } \\
\text { \& Pride } \\
(1989)\end{array}$ & $\begin{array}{l}\text { Strategy } \\
\text { formulation } \\
\text { school }\end{array}$ & $\begin{array}{l}\text { Effectiveness of a } \\
\text { strategy in the Miles } \\
\text { \& Snow } 11978 \text { ) } \\
\text { typalogy is } \\
\text { contingent upon the } \\
\text { dymamics of the } \\
\text { market }\end{array}$ & $\begin{array}{l}\text { Fit as } \\
\text { matching and } \\
\text { fit as } \\
\text { mocteration }\end{array}$ & $\begin{array}{l}560 \text { barnks in } \\
7 \text { US states. }\end{array}$ & 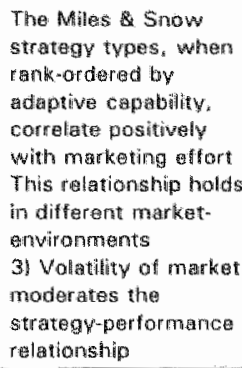 \\
\hline $\begin{array}{l}\text { Miller B Dess } \\
11993\end{array}$ & $\begin{array}{l}\text { Ovararching } \\
\text { gestait school }\end{array}$ & $\begin{array}{l}\text { To evaluate Porter"s } \\
\text { (1980) generic } \\
\text { strategies, on the } \\
\text { basis of simplicity, } \\
\text { accuracy and } \\
\text { generallizability. } \\
\text { through an ampirical } \\
\text { analysis of PIMS } \\
\text { data }\end{array}$ & Fit as gestalt: & $\begin{array}{l}200 \text { tirns in } \\
\text { PiNS data } \\
\text { base }\end{array}$ & 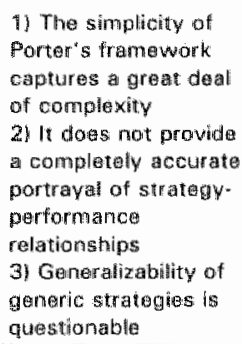 \\
\hline $\begin{array}{l}\text { Miller } 8 \\
\text { Friasen } \\
\text { (198Bal }\end{array}$ & $\begin{array}{l}\text { Owerarching } \\
\text { gestat school }\end{array}$ & $\begin{array}{l}\text { Cam Porter's } 11980 \text { ) } \\
\text { genieric strategies } \\
\text { be detected when } \\
\text { evialuating data in } \\
\text { the PIMS databuse? }\end{array}$ & Fit as gestalt & $\begin{array}{l}102 \text { sbus in } \\
\text { consumer } \\
\text { durable } \\
\text { industries } \\
\text { from PIMS } \\
\text { databasie }\end{array}$ & $\begin{array}{l}\text { Clustar analysis } \\
\text { revealis several } \\
\text { common and stable } \\
\text { types of strategiles. } \\
\text { None however } \\
\text { reflected Porter"s pure } \\
\text { types. Simultaneous } \\
\text { pursuit of cost } \\
\text { leadership and } \\
\text { differentilition } \\
\text { occurred often }\end{array}$ \\
\hline 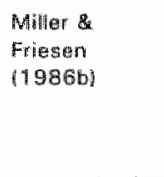 & $\begin{array}{l}\text { Qwerarching } \\
\text { gesteht schoot }\end{array}$ & $\begin{array}{l}\text { Are there: } \\
\text { performance } \\
\text { differences between } \\
\text { different grtatery } \\
\text { clusters? }\end{array}$ & Fit as gestalt & $\begin{array}{l}102 \text { SEUs in } \\
\text { consumine } \\
\text { ditarable } \\
\text { industries } \\
\text { from PIMS } \\
\text { databiase }\end{array}$ & $\begin{array}{l}\text { Success is calused by } \\
\text { possession of } \\
\text { strategic advantages } \\
\text { rather than by strict } \\
\text { adherence to Porter"s } \\
\text { types }\end{array}$ \\
\hline 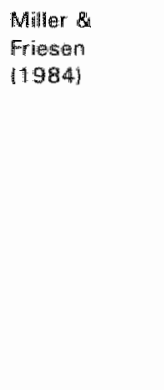 & $\begin{array}{l}\text { Overarching } \\
\text { gestaft schnol }\end{array}$ & $\begin{array}{l}\text { Organizations } \\
\text { exhibit an iniernal } \\
\text { congruence } \\
\text { between } \\
\text { environment, } \\
\text { stratery, structure } \\
\text { and decision making } \\
\text { nethods in each } \\
\text { phase of the } \\
\text { corporate life cycle. } \\
\text { This match changes } \\
\text { as an organization } \\
\text { moves to the next } \\
\text { phase. }\end{array}$ & Fitt as gestalit & $\begin{array}{l}36 \text { US } \\
\text { companies }\end{array}$ & 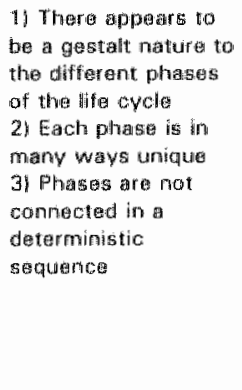 \\
\hline
\end{tabular}




\begin{tabular}{|c|c|c|c|c|c|}
\hline Aluthor & $\begin{array}{l}\text { Perspetive } \\
\text { Menkatraman, } \\
19841\end{array}$ & Theme & $\begin{array}{l}\text { Type of fit } \\
\text { Nenkatraman, } \\
1989 \text { l }\end{array}$ & Sample & Fiesurts \\
\hline Miller (19a8) & $\begin{array}{l}\text { Integrated } \\
\text { formulation and } \\
\text { implementation } \\
\text { school }\end{array}$ & 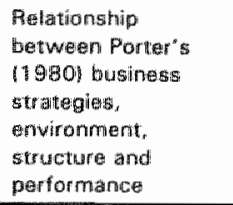 & $\begin{array}{l}\text { Fit as } \\
\text { matching }\end{array}$ & $\begin{array}{l}89 \text { Canadian } \\
\text { firms in } \\
\text { various } \\
\text { industries: }\end{array}$ & $\begin{array}{l}\text { Sitrategies must be } \\
\text { matched with } \\
\text { complementary } \\
\text { environments and } \\
\text { structures to promote } \\
\text { success }\end{array}$ \\
\hline $\begin{array}{l}\text { Miller } \\
\text { (1987a) }\end{array}$ & $\begin{array}{l}\text { Stratregic choice } \\
\text { school }\end{array}$ & $\begin{array}{l}\text { Pelationship } \\
\text { botween strategy- } \\
\text { making and } \\
\text { organizationat } \\
\text { structures and its } \\
\text { implications for } \\
\text { performance }\end{array}$ & $\begin{array}{l}\text { Fit as gestealt } \\
\text { aind fit as } \\
\text { mathching }\end{array}$ & $\begin{array}{l}97 \text { Canadian } \\
\text { firms in } \\
\text { various } \\
\text { industries }\end{array}$ & $\begin{array}{l}\text { Findings show } \\
\text { numerous significant } \\
\text { associations betwean } \\
\text { strategy-making and } \\
\text { structure, particularly } \\
\text { for formal integration } \\
\text { and decertrailization } \\
\text { and among successful } \\
\text { and inhovative firms }\end{array}$ \\
\hline $\begin{array}{l}\text { Miller } \\
11907 \mathrm{~b})\end{array}$ & $\begin{array}{l}\text { Integrated } \\
\text { formulation and } \\
\text { implementation } \\
\text { school }\end{array}$ & $\begin{array}{l}\text { Relationship } \\
\text { betwwen dimensions } \\
\text { of strategy content, } \\
\text { organizational } \\
\text { structurg and } \\
\text { enviromment }\end{array}$ & $\begin{array}{l}\text { Fit as } \\
\text { matcining }\end{array}$ & $\begin{array}{l}161 \text { US firms } \\
\text { and } 110 \\
\text { Canadion and } \\
\text { Australiain } \\
\text { finms an } \\
\text { various } \\
\text { industries }\end{array}$ & $\begin{array}{l}\text { Strategies of complex } \\
\text { product innovation, } \\
\text { marketing } \\
\text { differentiation, market } \\
\text { breadth and } \\
\text { conservative cost } \\
\text { control each have } \\
\text { very different } \\
\text { relationships with } \\
\text { bureaucratic and } \\
\text { organic structural } \\
\text { devices of uncertanty } \\
\text { reduction, } \\
\text { differentiation and } \\
\text { integration and with } \\
\text { denwironmental } \\
\text { dymamism, } \\
\text { heterogeneity and } \\
\text { hostility }\end{array}$ \\
\hline Miller 1986 ? & $\begin{array}{l}\text { Overarching } \\
\text { gesistalt sichool }\end{array}$ & $\begin{array}{l}\text { Relationship } \\
\text { botween seweral } \\
\text { common } \\
\text { configur ations of } \\
\text { strategr and } \\
\text { structure }\end{array}$ & $\begin{array}{l}\text { Filt as gestalt } \\
\text { and fint as } \\
\text { matching }\end{array}$ & Not applicable & $\begin{array}{l}\text { Four strategw- } \\
\text { structure types are } \\
\text { identified: simple } \\
\text { miche marketers. } \\
\text { macharistic cost } \\
\text { leaders, innovating } \\
\text { adhocracies and } \\
\text { divisionalized } \\
\text { conglomerates }\end{array}$ \\
\hline $\begin{array}{l}\text { Mithimary, Von } \\
\text { Glinow } \\
\text { Nathan } \\
11991 \text { : }\end{array}$ & $\begin{array}{l}\text { Owerarching } \\
\text { gestait school }\end{array}$ & $\begin{array}{l}\text { To develop a } \\
\text { tramework ory the } \\
\text { rotationship } \\
\text { between } \\
\text { organizational life } \\
\text { cycless and strategic } \\
\text { infernational HRM } \\
\text { and its implications } \\
\text { for fit and flexibility }\end{array}$ & $\begin{array}{l}\text { Propositions } \\
\text { have to be: } \\
\text { tested treating } \\
\text { fit as gestalt }\end{array}$ & Not applicable & Noit applicable \\
\hline
\end{tabular}




\begin{tabular}{|c|c|c|c|c|c|}
\hline Althor & $\begin{array}{l}\text { Perspoctive } \\
\text { Menkatraman. } \\
19841\end{array}$ & Theme & $\begin{array}{l}\text { Type of kit } \\
\text { fvenkatranan } \\
1989\end{array}$ & Semple & Prestututs \\
\hline $\begin{array}{l}\text { Morrison \& } \\
\text { Roth (1992) }\end{array}$ & $\begin{array}{l}\text { Strategy } \\
\text { formulation } \\
\text { school }\end{array}$ & $\begin{array}{l}\text { To develop a } \\
\text { taxenomy of } \\
\text { business lewel } \\
\text { straregy in globat } \\
\text { industries }\end{array}$ & Fit as gestalt & $\begin{array}{l}11 \text { is US firms } \\
\text { in global } \\
\text { industries }\end{array}$ & 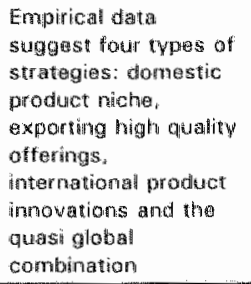 \\
\hline $\begin{array}{l}\text { Naman } \\
\text { Slevirn (1993) }\end{array}$ & $\begin{array}{l}\text { Integrated } \\
\text { formulation and } \\
\text { implementation } \\
\text { school }\end{array}$ & $\begin{array}{l}\text { Relationship } \\
\text { between } \\
\text { entrepreneurship } \\
\text { and the firm's fit } \\
\text { with the } \\
\text { environment }\end{array}$ & $\begin{array}{l}\text { Fit as } \\
\text { matching and } \\
\text { fit as gestalt }\end{array}$ & $\begin{array}{l}\text { 82 US tirms in } \\
\text { advanced } \\
\text { technology } \\
\text { mamufacturing }\end{array}$ & $\begin{array}{l}\text { The fit between } \\
\text { enwaronmental } \\
\text { turbulence. } \\
\text { entreprentetrial style. } \\
\text { organization structure } \\
\text { and mission strategy } \\
\text { has a significant } \\
\text { effect or performance }\end{array}$ \\
\hline $\begin{array}{l}\text { Parker \& } \\
\text { Helms } 11992 \text { ) }\end{array}$ & $\begin{array}{l}\text { Strategy } \\
\text { formulation } \\
\text { school }\end{array}$ & $\begin{array}{l}\text { What are the } \\
\text { relationships } \\
\text { between singular } \\
\text { and mixed generic } \\
\text { strategies in a } \\
\text { declining industry? }\end{array}$ & $\begin{array}{l}\text { Fit as } \\
\text { covariation } \\
\text { ano fit as } \\
\text { gestalt }\end{array}$ & $\begin{array}{l}48 \text { US and } 39 \\
\text { UK llirms in } \\
\text { the textils mili } \\
\text { products } \\
\text { industry }\end{array}$ & 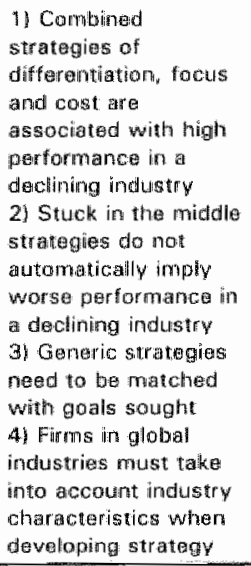 \\
\hline $\begin{array}{l}\text { Parthasarthy } \\
\text { \& Sewhi } \\
01992\end{array}$ & $\begin{array}{l}\text { Integrated } \\
\text { formulation and } \\
\text { implementation } \\
\text { school }\end{array}$ & $\begin{array}{l}\text { To develop a } \\
\text { frimework to study } \\
\text { the impact of } \\
\text { flexibio automation } \\
\text { on business } \\
\text { strattegy and } \\
\text { organizational } \\
\text { structure. Can a link. } \\
\text { with performance } \\
\text { be established? }\end{array}$ & Not applicable & Not applincable & 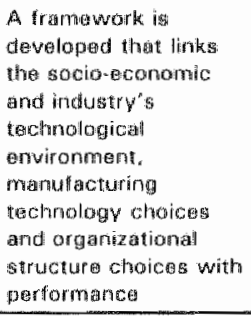 \\
\hline $\begin{array}{l}\text { Powell } \\
\text { 11992 }\end{array}$ & $\begin{array}{l}\text { Integrated } \\
\text { formulation and } \\
\text { implementation } \\
\text { schaol }\end{array}$ & $\begin{array}{l}\text { What are the } \\
\text { performance } \\
\text { consequences of } \\
\text { organizat tonal } \\
\text { alignments in: } \\
\text { relation to industry } \\
\text { variables, market } \\
\text { share and strategy? }\end{array}$ & $\begin{array}{l}\text { Fit as } \\
\text { matching and } \\
\text { fitt as } \\
\text { moderation }\end{array}$ & $\begin{array}{l}113 \text { US firms } \\
\text { in wood } \\
\text { wolholsterad } \\
\text { ind ustry }\end{array}$ & 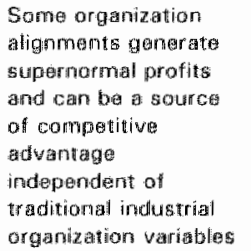 \\
\hline
\end{tabular}




\begin{tabular}{|c|c|c|c|c|c|}
\hline Author & $\begin{array}{l}\text { Perspective } \\
\text { Wenkatraman, } \\
1984 \text { ) } \\
\end{array}$ & Theme & $\begin{array}{l}\text { Type of fit } \\
\text { Wenkatranant } \\
\text { (989) }\end{array}$ & Sampla & Resuts \\
\hline $\begin{array}{l}\text { Aobinson } 8 \\
\text { Partom } \\
(1988)\end{array}$ & $\begin{array}{l}\text { Sitrategy } \\
\text { implementation } \\
\text { schoo! }\end{array}$ & $\begin{array}{l}\text { The influence of } \\
\text { planning } \\
\text { sophthistication on } \\
\text { the strategy } \\
\text { performance } \\
\text { relationsing }\end{array}$ & $\begin{array}{l}\text { Filt as gestalt } \\
\text { mind fit as: } \\
\text { moderation }\end{array}$ & $\begin{array}{l}97 \text { us } \\
\text { manufacturing } \\
\text { films in } 60 \\
\text { different } \\
\text { industries }\end{array}$ & $\begin{array}{l}\text { Finms with a fhish to } \\
\text { moderatelly } \\
\text { sophisticated planning } \\
\text { process and a } \\
\text { consistent strategic } \\
\text { oftentation as well as } \\
\text { firms with highly } \\
\text { sophisticated planning } \\
\text { processes and a } \\
\text { moderately consistent } \\
\text { strategic orientation } \\
\text { will be thigh } \\
\text { performers }\end{array}$ \\
\hline Roth $(1992)$ & $\begin{array}{l}\text { Sirategy } \\
\text { implementation } \\
\text { scliool }\end{array}$ & $\begin{array}{l}\text { To determine the } \\
\text { basic configuration } \\
\text { and coordination } \\
\text { patterns in medium. } \\
\text { sized firms in global } \\
\text { industries to analyze } \\
\text { the implementation } \\
\text { of international } \\
\text { strategy }\end{array}$ & Fit as gesturte & $\begin{array}{l}126 \text { US } \\
\text { businesses in } \\
9 \text { global } \\
\text { industries }\end{array}$ & $\begin{array}{l}\text { Five clusters emerge: } \\
\text { conciantrated hub } \\
\text { locall innowator, } \\
\text { transnational } \\
\text { innovator, regional } \\
\text { federation and } \\
\text { primary gliobell }\end{array}$ \\
\hline $\begin{array}{l}\text { Schuler } \\
\text { (1) } 987 \text { a) and } \\
\text { Schuler \& } \\
\text { Jacksion } \\
\text { (1987) }\end{array}$ & $\begin{array}{l}\text { Strategy } \\
\text { implementation } \\
\text { sichool }\end{array}$ & $\begin{array}{l}\text { Relationsthip } \\
\text { between } \\
\text { orgamizational } \\
\text { strategy. } \\
\text { organization level } \\
\text { and HAM practices }\end{array}$ & $\begin{array}{l}\text { Fit as } \\
\text { matching }\end{array}$ & $\begin{array}{l}304 \text { business } \\
\text { units in } \\
\text { various } \\
\text { industries }\end{array}$ & $\begin{array}{l}\text { HPM practices differ } \\
\text { across organizations } \\
\text { with different. } \\
\text { strategies. The } \\
\text { differences ane farger } \\
\text { within than across } \\
\text { organizationis } \\
\end{array}$ \\
\hline Shan 11990 i & $\begin{array}{l}\text { Integrated } \\
\text { formulation and } \\
\text { implementation } \\
\text { school }\end{array}$ & $\begin{array}{l}\text { What are the } \\
\text { determinants that } \\
\text { induce } \\
\text { entrepreneurial high } \\
\text { technology firms to } \\
\text { form cooperative } \\
\text { relationships? }\end{array}$ & $\begin{array}{l}\text { Fill ass } \\
\text { moderation }\end{array}$ & $\begin{array}{l}278 \text { US tirms } \\
\text { in bio } \\
\text { technology } \\
\text { industry }\end{array}$ & $\begin{array}{l}\text { The interaction of } \\
\text { environmental and } \\
\text { firm-specific wariables } \\
\text { detarmines strategy. } \\
\text { Cooperative behavior } \\
\text { is positively correllated } \\
\text { with the dlistance of a } \\
\text { firm' competitive } \\
\text { possition in rellaton to } \\
\text { its rivals: }\end{array}$ \\
\hline $\begin{array}{l}\text { Smith, } \\
\text { Guthrie } 8 \\
\text { Chen (1989) }\end{array}$ & $\begin{array}{l}\text { Overarching } \\
\text { gestati school } \\
\text { and stratogy } \\
\text { invalumentation } \\
\text { school }\end{array}$ & $\begin{array}{l}\text { 11 To test the } \\
\text { wallidity of Miles and } \\
\text { Snow's it978) } \\
\text { typelogy } \\
\text { 2) The relationship } \\
\text { between Miles and } \\
\text { Snow's strateigies. } \\
\text { size and } \\
\text { performance }\end{array}$ & $\begin{array}{l}\text { Fit as } \\
\text { covarietion } \\
\text { and fit as } \\
\text { moderation }\end{array}$ & $\begin{array}{l}47 \text { US } \\
\text { enlectironic } \\
\text { manufacturing } \\
\text { firms }\end{array}$ & $\begin{array}{l}\text { Findings with regare } \\
\text { to analwzers and } \\
\text { prospectors resemble } \\
\text { Miles and Snow's } \\
\text { model lnconsistencies } \\
\text { appear with regard to } \\
\text { the defender findings. } \\
\text { Defenders, analyzers } \\
\text { and prosipectors } \\
\text { outperform reactors. } \\
\text { Surategy and size } \\
\text { have an interactive } \\
\text { effect on performance }\end{array}$ \\
\hline $\begin{array}{l}\text { Thomas, } \\
\text { Clark and } \\
\text { Gioia (1993) }\end{array}$ & $\begin{array}{l}\text { Sthategic choico } \\
\text { solnod }\end{array}$ & $\begin{array}{l}\text { What are the direct } \\
\text { and indirect effects } \\
\text { of three strategic } \\
\text { sensus-making } \\
\text { activities, scainning, } \\
\text { interpretation and } \\
\text { action, on } \\
\text { performance? }\end{array}$ & $\begin{array}{l}\text { Fitt as } \\
\text { mediation }\end{array}$ & $\begin{array}{l}156 \text { US } \\
\text { hospitals }\end{array}$ & $\begin{array}{l}\text { Significant direct and } \\
\text { indirect links between } \\
\text { cognitiva tasks of } \\
\text { scanining. } \\
\text { interpretation and } \\
\text { actions and } \\
\text { pertormance are } \\
\text { established }\end{array}$ \\
\hline
\end{tabular}




\begin{tabular}{|c|c|c|c|c|c|}
\hline Aurhor & $\begin{array}{l}\text { Perspective } \\
\text { Nenkatraman, } \\
1984 \text { ) }\end{array}$ & Therne & $\begin{array}{l}\text { Type of fit } \\
\text { TVenkatraman, } \\
19891\end{array}$ & Somple & fhesults \\
\hline $\begin{array}{l}\text { Venkatraman: } \\
\text { \& Pfescott } \\
(1990)\end{array}$ & $\begin{array}{l}\text { Strategr } \\
\text { formulation } \\
\text { school }\end{array}$ & $\begin{array}{l}\text { Does a business in } \\
\text { which the stirategic } \\
\text { resources are } \\
\text { aligned to the } \\
\text { requirements of the } \\
\text { environment. } \\
\text { outperforma } \\
\text { business in which } \\
\text { this is not the case? }\end{array}$ & $\begin{array}{l}\text { Fit as profile } \\
\text { clewiation }\end{array}$ & $\begin{array}{l}1638 \text { SBUS } \\
\text { from PIMS } \\
\text { data bases ing } \\
\text { first sampla } \\
\text { and } 821 \text { SBUs } \\
\text { from PIMS } \\
\text { data base in } \\
\text { sacond sample }\end{array}$ & $\begin{array}{l}\text { Coalignment of } \\
\text { enviroment with } \\
\text { strategy thas a } \\
\text { positime inpact on } \\
\text { penformance }\end{array}$ \\
\hline Whate 1986 & $\begin{array}{l}\text { Strategy } \\
\text { implementation } \\
\text { school }\end{array}$ & $\begin{array}{l}\text { Relationship } \\
\text { between Portter }{ }^{\text {s }} \\
\text { llygol generic } \\
\text { strategies of overall } \\
\text { cost leadership and } \\
\text { differentiation, } \\
\text { organizational } \\
\text { context and } \\
\text { performance }\end{array}$ & $\begin{array}{l}\text { Fit as } \\
\text { matching }\end{array}$ & $\begin{array}{l}69 \text { SBUS in } \\
\text { valious } \\
\text { industries } \\
\text { from PlimS } \\
\text { data base }\end{array}$ & 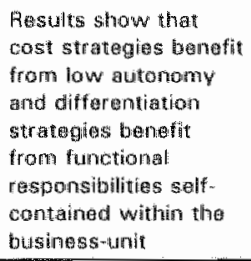 \\
\hline $\begin{array}{l}\text { Wright. Knoll, } \\
\text { Tu \& Helms } \\
\text { 11991) }\end{array}$ & $\begin{array}{l}\text { Overarching } \\
\text { gestalt schood }\end{array}$ & $\begin{array}{l}\text { Felationship } \\
\text { between generic } \\
\text { strategies of loww } \\
\text { cost, differentiation } \\
\text { and a combination } \\
\text { of both and } \\
\text { performance within } \\
\text { the surew machine } \\
\text { products industry }\end{array}$ & Fit as gestalt & $\begin{array}{l}56 \text { us firms in } \\
\text { screw } \\
\text { machine } \\
\text { praducts } \\
\text { industasy }\end{array}$ & 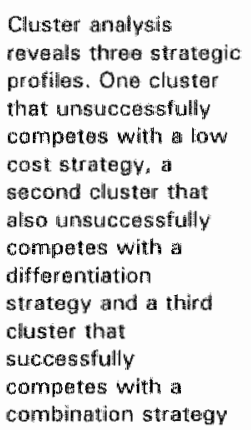 \\
\hline $\begin{array}{l}\text { Zaikra \& } \\
\text { Cowin }(1993)\end{array}$ & $\begin{array}{l}\text { Strategy } \\
\text { implementation } \\
\text { school }\end{array}$ & $\begin{array}{l}\text { Rolationship } \\
\text { between technollogy } \\
\text { policy. generic } \\
\text { business strategy } \\
\text { and performance }\end{array}$ & $\begin{array}{l}\text { Fit as } \\
\text { matching and } \\
\text { fit as gestalt }\end{array}$ & $\begin{array}{l}103 \text { US } \\
\text { maanuflacturing } \\
\text { based firms in } \\
28 \text { mature } \\
\text { industrigs }\end{array}$ & 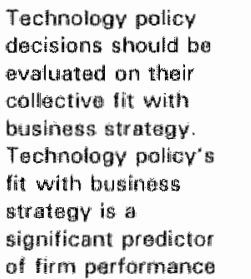 \\
\hline
\end{tabular}

Table 1.3: Sample of empirical studies 1983-1993

The sample of studies in Table 1.3 suggests at least four conclusions relevant to the study in this book:

1) All the studies, except Parker \& Helms 11992), use American data. Whether the various relationships between the environment, structure and strategy and its impact on performance also hold for European firms has barely been tested. Especially in the light of societal effects (Sorge, 1991), one would expect differences between countries in structural elements such as HRM practices and production structures. These differences would, in a contingency perspective, also have an impact on the strategies pursued. 
2) To study an environment-structure-strategy fit, a multi-industry context is necessary to reveal the impact of differences in competitive industry environments. The majority of studies, nineteen, have indeed used a sample from various industries. But thirteen studies, including the only study using European data, use a single-industry context.

3) Although twelve out of thirty-seven studies, address issues relating to the implementation of strategy, they all focus on one specific element. For example, strategy is related to types of structure (two studies), size (one study), technologicalissues (two studies). HRM fone study), administrative mechanisms (four studies) and marketing competencies (one study). Kotha \& Orne (1989) is the only study in which types of organization structure, manufacturing structure and strategy are related. Their findings, however, have not been tested empirically. Since the effective implementation of strategy involves the alignment between many internal elements, there is a need for empirical studies which attempt to deal with more than one element.

4) Only six out of thirty-seven studies, looked at specific relationships between the environment, structure and strategy integratively. And most of these studies were limited to studying just a few variables. Although there is a somewhat larger body of research in the gestalt perspective which addresses configurations of environmental, structural and strategy variables simultaneously, the focus in this perspective is not on the examination of the specific separate relationships. A combination of both views is desired to gain understanding of the overall configuration and underlying specific relationships.

\section{Summary:}

These conclusions have the following consequences for our study:

1. A sample of companies in two European countries will be examined.

2. A sample of companies in two different industries will be studied.

3. Multiple elements internal to the organization - specifically the manufacturing structure and HRM - are analyzed in relation to the environment and strategy.

The specific research method used is discussed in Chapter 2.

\subsection{Conclusion}

The preceding chapter provides an overview of different theoretical perspectives in the overarching framework of the (neo) contingency approach. Despite the rich theoretical tradition in this approach and the large number of associated empirical studies, we still belleve that this study can offer added value in two senses.

Firstly, the research questions presented in the Introduction address more than 
one theoretical perspective. All of the research questions are analyzed based on the assumptions of the neo-contingency approach. So, it is assumed that a reciprocal influence exists between environmental demands and organizational and/or strategic characteristics. The importance of strategic choice is emphasized by the choice of the research design (see Chapter 2). In Chapter 5, where the adoption of human resource management in Great Britain and the Netherlands is investigated, the societal effect approach (Sorge, 1991) and the business system framework (Whitley, 1992) are also employed to seek additional explanations for the outcomes. Institutional and social embeddedness would be expected to be especially crucial for policies concerning personnel: therefore, potential differences between Great Britain and the Netherlands can be explained by viewing the organizations from this perspective. As was argued earlier, the decision to carry out the analysis within a neo-contingency framework implies looking for a fit between environmental, organizational and strategic elements. of the six perspectives of fit that Venkatraman (1984) considers, three are explicitly considered here. They all refer to the content rather than the process of fit, which follows from our content-definition of strategy (see the Introduction). The research question on the relationship between the competitive environment and generic strategies pursued addressed in Chapter 3, fits in the strategy formulation school, while the question on the relationship between the technological setting and human resource management analyzed in Chapter 6, would fall within the strategy implementation school. In Chapters 4 and 5 an integrated approach is taken, comparable to the integrated formulation and implementation school. Furthermore, two types of fit (Venkatraman, 1989) are considered: fit as 'gestalt" and fit as matching.

Secondly, the empirical part of this study can produce added value because it analyzes the research questions in the context of wo industries and in two countries. Two industries are examined to gain more insight into the relationship between the competitive environment and organizational and strategic characteristics. Is this relationship the same in both industries or does it differ between the food $\&$ drink and chemical industry? Two countries are examined to explore potential differences between the organizations in Great Britain and the Netherlands. Are differences in generic and specific strategies so large that organizations in one of the two nations have a competitive advantage over the other? Or has the increasing globalization led to an increasing isomorphism?

This study is not expected to rigorously test these questions, but rather to explore the nature of the relationships between the competitive environment, generic and specific strategies in the two industries and two European countries. The research methods chosen to approach these questions will be the subject of the next chapter. 


\title{
CHAPTER 2
}

\author{
RESEARCH DESIGN
}

This chapter presents the framework within which the data have been collected. Section 2.1 describes the context of the research project, and Section 2.2 discusses the sample of companies. Finally, Section 2.3 summarizes the method of data collection.

The context: the International Organizational Observatory (IOO)

In 1988, a European-wide research group was set up in order to perform an international comparative investigation of the functioning of large business organizations in European countries. When the Netherlands joined in 1990, this group the International Organizational Observatory (1OO) - consisted of teams of researchers at universities and other research institutes in France, Germany, Great Britain, Italy and Spain. A Swedish research team joined in $1991^{4}$.

To ensure inter-country comparability of data, several agreements on the data collection in the different countries were reached before the Dutch team joined. These agreements pertained to the questionnaire used and the selection of companies in the different countries. The set up of the questionnaire will be discussed in more detail in Section 2.3. The criteria relating to the selection of companies are threefold:

1. The turnover of the companies should place them among the largest 1,000 corporations in the participating countries.

2. The companies have to be manufacturing companies.

3. The industrial sector in which the companies operate should relate to the industries that had already been selected in the other participating countries. Most of the companies that were studied in ltaly, Spain, France, Germany and Great Britain were in the chemical \& pharmaceutical industry, the electronics branch, the food \& drink industry and mechanical engineering.

4. The unit of analysis is defined as that part of the organization where

4 The 100 group was inaugurated by CRORA, Bocconi University, Milan, Italy. It currently consists of dedicated research teams based at CRORA (Italy), ESSEC (France), ESADE (Spain), Open University (Great Britain), University of Uppsala (Sweden) and MANOR (the Netherlands). 
management has the greatest autonomy concerning production and marketing decisions regarding (a) specific product line(s). The rationale behind this definition is to incorporate strategic choice in the analysis and to underline that the interaction and/or coordination that exists between internal ements of the organization is not merely determined by contingency forces, but is also based on managerial choice (Venkatraman \& Camillus, 1984).

Despite these agreements on the choice of a sample, many problems emerged in matching the results from the research efforts of the diverse teams. When the time came for the analysis phase of our own study, only data from the British team were avallable in a comparable form. The French data had been processed on a statistical computer package called SAS, while all the other countries processed their data using SPSS. It was not until the beginning of 1994 that the means were found to make the French data available to other countries on SPSS. The German team had significantly altered the questions in the questionnaire, rendering their results almost incomparable to those of the other teams. The Italian data were received with the remark that a 'cleaned' data set in a more comprehensible format would soon follow, but this has not yet been sent. The Spanish team mailed elaborate descriptive reports of their data, but the raw data were also never received. Finally, the Swedish team was still in the process of collecting data. These difficulties in international cooperation are, of course, to be expected in a pioneer attempt to achieve European-wide collaboration with such a diverse group of researchers. Lessons have been learned, however, from past experience and the current format of the 100 project points to some very promising avemues for future research (see also Chapter 8 ).

The ways in which the 100 context affects this study are elaborated upon in the next two sections.

\section{The sample of companies}

The four criteria regarding the selection of companies, which were outlined in Section 2.1, obviously restricted the choice of a sample in the Netherlands. The selection of companies therefore took place in two steps.

The first step was the collection of data on the turnover of the larglest corporations in the Netherlands. Starting with a list of 1990 turnovers (Financieele Dagblad, 19911, annual reports were obtained for fifty-one manufacturing organizations belonging to the top 100 companies in the Netherlands. These reports were examined to identify potential units of analysis within the organization. Since access to companies appeared to be very difficult - especially because of the amount of time consumed by the investigation - and to be largely dependent on obtaining references from people known to the manager who was contacted, no a priori 
selection of industrial sectors was made at this point. A list was then prepared of potential units of analysis within the fifty-one manufacturing organizations, and references were sought from a variety of people whose names might carry weight with contacts in these organizations. This resulted in an initial mailing of a request to cooperate to twenty-three companies. Of these, ten agreed to cooperate in the investigation. Seven of these ten companies belonged to the top-50 corporations in the Netherlands with a turnover larger than 2,090 million Dutch Guilders in 1990. Three companies were situated in the ranking between 51 and 100 with a turnover between 951 and 2,090 million Dutch Guilders. They were distributed, though unevenly, over four industries: aerospace, chemicals, food \& drinks and paper \& board.

The second step was to extend the sample with firms outside the top 100 but with turnover over 150 million Dutch Guilders. Two industrial sectors, namely chemicals and food $\&$ drinks, were selected. This choice was not arbitrary since, first. eight of the firms that already agreed to cooperate are in these sectors and, second, from all the industrial sectors covered in the other 100 countries, food \& drinks and chemicals are largest in Dutch industry. Together these sectors generatted $42 \%$ $(26.6 \%$ and $15.4 \%$, respectively) of the totall turnover of all manufacturing industries in the Netherlands in 1991 (CBS Statistical Yearbook, 1993). Two industrial sectors were selected, rather than one, because of the desire to examine the research propositions in a multi-industry context (see Chapter 1). Again using the listing on 1990 turnovers (Financieele Dagblad, 1991), annual reports were obtained from twenty-eight chemical firms and thirty-six food \& drink companies. After inspection of the appropriate unit of analysis within the companies and the search for people who could provide references, eleven requests for cooperation were mailled. This resulted in another three companies, all in the food \& drink industry, which agreed to cooperate. Their turnover varied from 100 to 500 million Dutch guilders.

The 100 definition of the unit of analysis boiled down to conducting the research in a division or a business unit in ten of the participating companies. In the other three cases the entire autonomous company remained the unit of analysis. Since within one of the participating chemical companies two divisions agreed to cooperate, fourteen units of analysis were ultimately included in the research. In the remainder of this book the fourteen units of analysis will be referred to as fourteen 'companies'. The rationale behind this labeling is that in the case of a division or business unit the unit of analysis is a company within the company, each with its own product line(s), competitive environment, strategy, structure, et cetera.

The inspection of the sample of empirical studies in Section 1.4 also induced the wish to examine the research questions in more than one European country. Although data had been collected in all of the countries participating in the 100 , only the data gathered in Great Britain are used in this study because at the time of analysis data from other countries were either unavailable or incompatible (see Section 2.1).

The data in Great Britain were gathered by a team of three researchers, - Dr. T. 
Clark, Dr. G. Mallory and Prof. Dr. D. Pugh - based at the Open University. Their sample consists of twenty-four companies of which five are in the food $\&$ drink indusitry, three in chemicals, six in engineering, four in electronics, two in pharmacy, two in construction and, finally, two companies operate in other sectors that are not further specified. The special emphasis in the Dutch sample on the chemical and food \& drink industry is also justified in Great Britain, since $42 \%$ of the firms in The Times Top 1000 operate in either industry $128 \%$ in the chemical industry and $14 \%$ in the food \& drink industry) (Clark, Mallory \& Pugh, 1993). The turnover of the companies interviewed in Great Britain ranged from 109 to 33,039 million British pounds with an average of 11,607 million British pounds. The unit of analysis consisted, like in the Netherlands, mainly of divisions and business units within the selected companies. In only two cases the unit of analysis referred to the entire autonomous company.

The sample in the Netherlands and Great Britain is summarized in Table 2.1.

\begin{tabular}{|c|c|c|c|}
\hline \multicolumn{2}{|c|}{ Sample in different sectors } & \multirow{2}{*}{ The Necherlands } & \multirow{2}{*}{$\frac{\text { Great Britain }}{0}$} \\
\hline 1. & Aerospace & & \\
\hline 2. & Chemicals & 5 & 3 \\
\hline 3. & Construction & 0 & 2 \\
\hline 4. & Electronics & 0 & 4 \\
\hline 5. & Engineering & 0 & 6 \\
\hline 6. & Food \& Drinks & 7 & 5 \\
\hline 7. & Paper \& Board & 1 & 0 \\
\hline 8. & Pharmacy & 0 & 2 \\
\hline 9. & Other & 0 & 2 \\
\hline & TOTAL & 14 & 24 \\
\hline
\end{tabular}

Table 2.1: Sample of companies in the Netherlands and Great Britain

Because of the rather complicated definition of the unit of analysis and the therefore somewhat artificial definition of the company concept some data regarding turnover. ownership relations and internationalization will be presented.

The size of the Dutch companies (i.e., units of analysis) in terms of turnover waried from 250 to 3,500 million Dutch gullders with an average of 889 million Dutch guilders. The turnover of the British companies (i.e., units of analysis) ranged from 6 to 3,145 million British pounds with an average of 1,061 million British pounds. So, the companies in the British sample are larger in terms of turnover than the Dutch companies. In the Netherlands all of the companies intervievved are privately owned. However, seven of these companies - three as a business unit and four as a private limited company - are part af a publicly listed corporation. The other seven companies are owned by a family (one company), the members of a co-operative corporation 
(three companies) or by a private hollding (three companies). The owners in the Netherlands are predominantly Dutch, only one firm is half owned by a German corporation. In Great Britain all of the companies interviewed are directly (two companies) or indirectly (twenty-two companies) publicly owned. Eighteen companies are private limited companies within a publicly listed corporation and four companies. being business units, have no separate legal entity but also belong to a publicly held firm. The owners are predominantly British, although two companies are American and one is Canadian owned. Both the Dutch and the British companies are very intermationally oriented. In the Netherlands the three most popular countries to do business with are Belgium 171\% of the companies), Germany and France (64\% of the companies in both cases). Also the British companies mainly do business with France and Germany ( $88 \%$ of the companies). The USA and Canada - with $67 \%$ of the companies operating there - rank third. The most popular way to service foreign markets in the Netherlands as well as in Great Britain is through exporting. A complete list of the chemical and food \& drink companies in the sample with some of their characteristics is presented in Appendix A. Since the companies preferred to remain anonymous, they have been assigned a number which is used throughout the book.

As can be concluded from the sample selection, the sample is by no means drawn randomly. A canvenience sample (based on the ability to secure references) was employed because of the severe difficulties in obtaining cooperation from companies. Although this hampers the generalizability of the findings, it was not found an impediment because of the exploratory nature of the research. As was discussed in Section 2.1, the 100 was a pioneer attempt at building a European-wide data base on the functioning of organizations. The questionnaire was also developed for that purpose and thus not with this specific research project in mind. This implies that the use of the questionnaire in this project also entails a first step in the validation process. So, besides the fact that additional insights in the relationship between the competitive environment, generic and specific manufacturing and HRM strategies can be obtained, this project should also contribute to improve the construct validity of the 100 questionnaire.

\subsection{Data collection method}

The framework within which the data are collected is a cross-sectional survey design. This entails the systematic collection of data on a number of units at a given moment in time in order to arrive at a body of quantifiable data which are examined for patterns of association (Bryman, 1989). The method with which the dlata are collected is a questionnaire developed by the members of the 100 that was mainly set up in a standardized format, but does include some open-ended questions.

To adapt the 100 questionnaire to the Dutch situation, the original Italian version 
was first translated into Dutch. This translation was compared with the English, German and French translation of the instrument and, finally, with the English translation of the German and French questionnaires to control for mistakes concerning the translation and interpretation of the questions. The Dutch version of the questionnaire was then tested with a company in the paper \& board industry. Subsequently, the questionnaire was slightly modified in some areas to fit the circumstances of Dutch business life. The final version of the questionnaire consists of ten different parts. These are:

1. profile of the company:

2. inter-organizational relations;

3. strategy and the competitive environment;

4. production systems;

5. research and development;

6. organization structure;

7. pllanning and control systems:

8. decision making (centralization and decentralization);

9. information systems; and

10. personnel management.

Data on these ten parts were gathered in structured interviews with members of the management team, or their representatives, of the companies. Because the questions were aimed at obtaining a general averview of the operations within the functional areas, the members of the management team served as experts. On average ten interviews, ranging from half an hour to two hours, were conducted in most of the companies. Five to six members of the management team (or their representatives) were usually involved, each addressing different parts of the questionnaire. This was done to reduce one of the risks associated with key informant research: the inability of any one individual to provide accurate information on the organization as a wholle (Bryman, 1989). The risk of common method variance (Podsakoff \& Organ, 1986) could not be avoided, since only on HRM in the Dutch companies limited additional data in the form of social and annual reports - could be obtained.

Although in the context of the 100 research project data are collected on all ten parts of the questionnaire ${ }^{5}$, a relatively small part of these data is actually used to analyze the research questions in this study. A choice between topics was made for three reasons. First, as was discussed in the Introduction, a central theme in organization theory and strategic management is the relationship between the competitive environment, generic and specific strategies. Specific strategies regarding manufacturing technology and HRM were selected, because these represent key elements in the functioning of the organizations. Second, the topics chosen provided

5 All the data collected in the Netherlands are presented in the Dutch descriptive report (Heijltjes, Sorge \& Van Witteloostuijn, 1993). 
richer and more interesting material than the parts on overall organization structure, planning and control systems and information systems. However, since data on the other topics are available, the current analysis can be extended to other specific strategies in future research. Finally, time constraints necessitated a choice between topics.

In the empirical Chapters 3 through 7, the measurement of the different concepts and the techniques of data analysis will be discussed in detail. The description here is confined to a summary in Table 2.2 indicating which parts of the questionnaire are employed for the analysis of each of the research questions. The full text of these parts of the questionnaire in Dutch - for the Dutch questionmaire - and in English - for the British questionnaire - is presented in Appendix B.

\begin{tabular}{|c|c|c|c|}
\hline \multicolumn{2}{|c|}{ Research question } & \multicolumn{2}{|c|}{ Partls) of the questionnaire used } \\
\hline 1. & $\begin{array}{l}\text { Chapter } 3 \text { : relationship between the } \\
\text { competitive environment and strategy }\end{array}$ & Part 3: & $\begin{array}{l}\text { Strategy and the competitive } \\
\text { environment }\end{array}$ \\
\hline 2 & $\begin{array}{l}\text { Chapter } 4 \text { : relationship between } \\
\text { manufacturing technology, competitive } \\
\text { environment and strategy }\end{array}$ & $\begin{array}{l}\text { Part 3: } \\
\text { Part 4: }\end{array}$ & $\begin{array}{l}\text { Strategy and the competitive } \\
\text { ervironment } \\
\text { Production systems }\end{array}$ \\
\hline 4. & $\begin{array}{l}\text { Chapter 5: relationship berween HRM, } \\
\text { competitive enviromment and strategy }\end{array}$ & $\begin{array}{l}\text { Part } 3: \\
\text { Part } 10:\end{array}$ & $\begin{array}{l}\text { Strategy and the competitive } \\
\text { environment: } \\
\text { Personnel management }\end{array}$ \\
\hline 5 & $\begin{array}{l}\text { Chapter 6: relationship between the } \\
\text { technological setting and HRM }\end{array}$ & $\begin{array}{l}\text { Part } 4: \\
\text { Part 10: }\end{array}$ & $\begin{array}{l}\text { Production systems } \\
\text { Personnel management }\end{array}$ \\
\hline 6. & Chapter 7 : relationship with performance & Part 1: & Profile of the company \\
\hline
\end{tabular}

Table 2.2: Research questions and part(s) of the questionnaire used in analysis 


\section{CHAPTER 3}

\section{STRATEGIES PURSUED IN COMPETITIVE ENVIRONMENTS}

This chapter analyzes the relationship between the competitive environment and generic strategies. Section 3.1 provides a brief overview of literature on the competitive environment-strategy link. In Section 3.2 the competitive forces operating in Great Britain and the Netherlands are described. Section 3.3 summarizes these competitive forces by developing two environmental dimensions on which the companies in our sample are positioned. Section 3.4 establishes a link to the content of the generic strategies by examining the degree of formalization in strategy-making. The generic strategies in terms of Porter (1980) and Miles and Snow (1978) are presented in Section 3.5, while Section 3.6 explores the relationship of these strategies with the environmental dimensions. Support is provided for the hypothesis that different generic strategies are associated with different competitive environments. Finally, in Section 3.7, the presence of (strategic) groups is analyzed and Section 3.8 provides a conclusion. Whenever possible, the aggregated results are broken down into results for two of the specific sectors interviewed, namely chemicals and food \& drinks, to search for industry differentials. The relationships studied are summarized in Figure 3.1.

\subsection{The relationship between the competitive environment and generic strategies: a brief literature review}

As was explained in the Introduction, the environment considered in this chapter is the sub-environment. The sub-environment - or competitive environment - consists of all those factors that influence the functioning of a division or business unit. The difficulty, however, is to conceptualize the influencing factors in such a marner that they can be related to strategy. Not surprisingly this has been done in many different ways. Hambrick (1983a), for example, developed an empirical typology of mature industrial-product environments by identifying elight clusters in the PIMS database that each represent different enviranmental settings in which strategies can be further analyzed. One environmental setting that he identified, for example, is labeled "disciplined capital goods makers" and characterized by an infrequently purchased product, above average export levels and stable market shares. Another example of an empirically derived typology is the eight types of environments 


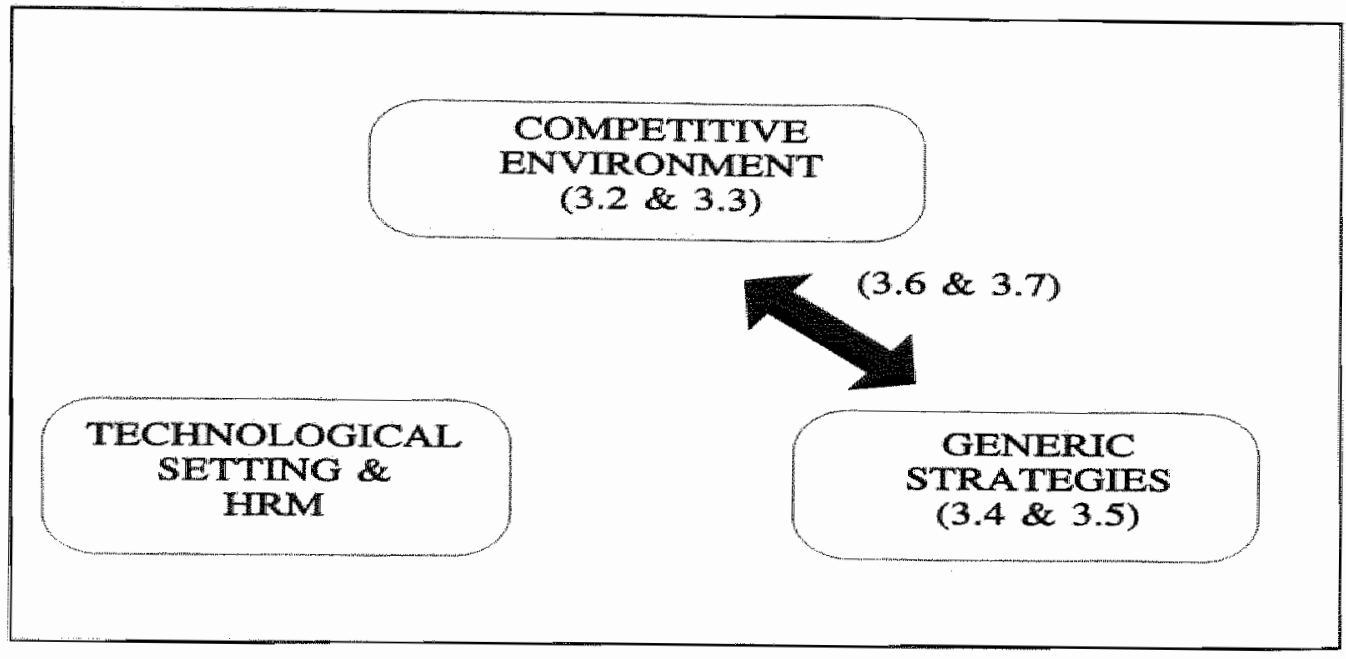

Figure 3.1: The relationship between the competitive environment and generic strategies

which Venkatraman \& Prescott (1990) - also based on PIMS data - identified. Their typology closely resembles Porter's (1980) typology of generic industries. Miller (1987b, 1988), on the other hand, assessed the environment in terms of uncertainty, unpredictability, dynamism and heterogeneity. Finally, one of the most well-known conceptual frameworks to relate the competitive environment to strategy are Porter's (1980) five competitive forces that drive competition in an industry. This framework will be discussed in Section 3.2.

Strategy in this chapter - as was discussed in the Introduction - refers to the content of strategy at the business level and thus studies how the company is competing in selected product-markets. Judging by the number of typologies that are developed on this topic it is - again - not easy to grasp the distinguishing features of different strategies. Some authors have developed classification schemes that apply to special circumstances. Morrison \& Roth (1992), for example, have derived an empirical taxonomy of four general business-level strategies for operating in global environments. They labeled these strategies: domestic productniche, exporting high quality offerings, international product innovation and quasiglobal competition. Also Herbert \& Deresky (1987) have developed an empirical typology of generic strategies and identified a develop strategy, a stabilize strategy, a turnaround strategy and a harvest strategy. Other authors have emphasized typologies that apply to a wider range of business level situations. Miller (1987b), for example, developed four strategic dimensions based on a literature review. He relates these dimensions - complex innovation, marketing differentiation, breadth and conservative control - to the organizational context. The most well-known typologies of generic strategies, however, are those developed by Miles \& Snow 
(1978) and Porter (1980). These will both be discussed in Sections 3.5 to 3.7. However, despite the fact that especilally Porter's classification is widely cited, it has also received some criticism. Chrisman. Hofer \& Boulton (1988), for example, argue that although Porter's typology contains many useful attributes, it also suffers from two flaws. For one, the scheme does not permit to distinguish between businesses that use different competitive weapons in different productmarket segments because it lacks a characteristic that refers to segment differentiation. Furthermore, Porter"s scheme is not collectively exhaustive because it defines 'stuck in the middle' strategies as leading to inferior performance. It has been demonstrated, however, that a combination of cost leadership and differentiation - defined as a 'stuck-in-the middle' strategy - is feasible to pursue (Miller \& Friesen, 1986a \& 1986b; Wright, Knoll, Tu \& Helms, 1991; and Cronshaw, Davis \& Kay, 1994). Also Miller \& Dess (1993) argue that although Porter's framework captures a great deal of complexity, it does not provide a completely accurate description of strategy-performance relationships. They find that hybrid strategies are also feasible and focus strategies are not as profitable as Porter (1980) suggests. Miller \& Dess, furthermore, question the generalizability of Porter's strategies, since their findings suggest that no strategic type is evenly scattered across industries. Despite these limitations the typology of Porter is still used to classify the firms in the Dutch sample. Especially the criticism concerning the pursult of hybrid strategies is, however, also addressed in Section 3.5 of this Chapter.

Finally, it is assumed that a fit between the competitive environment and strategy has to be established for the organization to perform effectively (see also Chapter 2). This hypothesis has been supported by numerous empiricall studies (for example: Dess \& Davis, 1984; Miller, 1988; McKee, Rajan Varadarajan \& Pride, 1989; Conant, Mokwa \& Rajan Varadarajan, 1990; Venkatraman \& Prescott, 1990; and Powell, 1992).

\subsection{Competitive forces in Great Britain and the Netherlands}

As was discussed in Section 3.1, one way to trace the competitive environment of an arganization is by studying the forces that drive competition in an industry. In the Netherlands and Great Britain the same set of statements was used to capture these competitive forces. The general manager (or his representative) was asked to rate these statements on a scale from 1 (incorrect description) to 4 (correct description). The original scale in the Netherlands was the reverse, so conversion of the scalle has taken place for comparative reasons (the complete list of items is described in Appendix B). This list of statements used resembles the set of factors which Porter (1980) used to construct his five competitive forces. These five 
forces are (i) the internal rivalry within the industry, (ii) the threat of potential entrants, (iii) the bargaining power of buyers, (iv) the bargaining power of suppliers and $(v)$ the threat of substitutes. In the following analysis, however, the individual statements are not combined into these five forces for three reasons. First, weighing factors for the individual statements are not available. For example, is the fact that there is just a slow rate of growth in the industry equally important for internal rivalry as the existence of scale advantages? Second, several items appear on more than one force, which leads to multicollinearity among the competitive forces. And, third, the items are unevenly distributed over the forces, resulting in an overemphasis of some of the items. Using the individual items, the question of interest for Great Britain and the Netherlands is fourfold:

Question 1: Does the competitive environment significantly differ over industries in Great Britain and the Netherlands?

Question 2: Does the chemical industry significantly differ from the food \& drink sector in Great Britain and the Netherlands?

Question 3: Does the competitive environment significantly differ in the chemical industry in Great Britain and the Netherlands?

Question 4: Does the competitive environment significantly differ in the food \& drink industry in Great Britain and the Netherlands?

To investigate the questions, non-parametric tests - specifically the Mann-Whitney test for two independent samples and the Kruskal-Wallis test for $k(>2)$ independent samples - were applied. These two tests require no assumptions on the shape of the underlying distributions and can be applied to small samples (Table 3.1). Special attention will be devoted to the chemical and food \& drink industries, since these are the only industries represented in both countries.

\begin{tabular}{||l|c|c|c|}
\hline & Great Britain & The Netherlands & Total number of companies \\
\hline Chemicals & 3 & 5 & 8 \\
\hline Construction & 2 & 0 & 2 \\
\hline Electronics & 4 & 0 & 4 \\
\hline Engineering & 6 & 0 & 6 \\
\hline Food \& Drinks & 5 & 7 & 12 \\
\hline Phamacy & 2 & 0 & 2 \\
\hline Other & 2 & 2 & 4 \\
\hline Total & 24 & 14 & 38 \\
\hline
\end{tabular}

Table 3.1: Distribution of companies over industries and countries 
Results question 1

Question \%: Does the competitive environment significantly differ over industries in Great Britain and the Netherlands?

The competitive environment in Great Britain and the Netherlands differs significantly $(p<0.05)$ over industries on seven of the seventeen competitive items. How the industries rank on these seven items is presented in Table 3.2. The higher the mean ranking of the industry, the higher the score on that competitive item and the more accurate the description reflects the competitive environment of that industry.

Inspection of Table 3.2 reveals that the extreme positions on most of the items are taken by the pharmaceutical and construction industries. The companies in the pharmaceutical industry apparently operate in a market in which the final consumer"s opinion is considered crucial - since the brand name is most important and advertising is fierce * but at the same time restricted because customers do not have complete information about the pharmaceutical market.

\begin{tabular}{|c|c|c|c|c|c|c|}
\hline & Pharmacy & Food \& drinks & Electronics & Chemicals & Engine ering & Construtetion \\
\hline Brand matme is importarnt & 27.50 & 22.67 & 18.25 & 12.13 & 12.63 & 10.50 \\
\hline $\begin{array}{l}\text { Switching cost for clients are } \\
\text { high }\end{array}$ & 18.00 & 10.33 & 20.25 & 19.38 & 24.17 & 27.00 \\
\hline $\begin{array}{l}\text { Entry into distribution chamanels } \\
\text { is difficult }\end{array}$ & 26.00 & 23.96 & 77.13 & 13.38 & 10.83 & 7.50 \\
\hline $\begin{array}{l}\text { A favarable location is } \\
\text { important }\end{array}$ & 22.50 & 20.38 & 9.75 & 21.44 & 14.00 & 5.50 \\
\hline Advertising is "ierce & 31.00 & 22.97 & 18.50 & 11.00 & 14.5 .0 & 9.00 \\
\hline $\begin{array}{l}\text { Customers have } \\
\text { information about the market }\end{array}$ & 13,00 & 26.00 & 13.00 & 17.00 & 10.00 & 4.50 \\
\hline $\begin{array}{l}\text { Easy access to raw moterials is } \\
\text { important }\end{array}$ & 8.50 & 22.71 & a. 50 & 24.13 & 10.25 & 0.50 \\
\hline
\end{tabular}

Table 3.2: Mean rankings of the industries in Great Britain and the Netherlands on the competitive items

The companies in the construction industry, on the other hand, seem protected from any large bargaining power of buyers. Their customers have the least information about the market compared to the other industries, as brand name and filerce advertising are not important and switching cost for clients are very high. This difference is not surprising since the nature of the product in both industries is very different. In the pharmaceutical industry the product is oriented toward the final customer, consumed in a limited amount of time and thus frequently repurchased, while in the construction industry the product is delivered to a customer with whom an enduring relationship needs to be build since one project consumes a lot of time and resources. Therefore, for the construction industry 
other competitive items like after-sales service and delivered quality in past projects are far more important than the items mentioned in Table 3.2.

\section{Results question 2}

Question 2: Does the chemical industry significantly differ from the food \& drink sector in Great Britain and the Nethertands?

Chemicals and food \& drinks differ significantly ( $p<0.025$ ) from each other on six of the seventeen items. The results are presented in Table 3.3. These results are not surprising when a number of key characteristics of the chemical and food $\&$ drink industry is considered (Commission of the European Communities, 1993). The food \& drink sector is the largest sector in European industry by generating $16.7 \%$ of total manufacturing industry turnover. The chemical industry ranks second with $11.3 \%$ of total European manufacturing industry turnover (CEF/C, 1993). In the following the chemical industry will be discussed first, followed by a description of the food \& drink sector.

\begin{tabular}{|l|c|c|}
\hline & Food \& drinks & Chemicals \\
\hline Brand name is important & 12.54 & 7.44 \\
\hline Switching cost for clients are high & 8.33 & 13.75 \\
\hline Entry into distribution channels is difficult & 12.88 & 6.94 \\
\hline Production capacity has been increased & 8.33 & 13.75 \\
\hline Advertising is fierce & 12.88 & 6.94 \\
\hline Customers have information about the market & 12.67 & 7.25 \\
\hline
\end{tabular}

Table 3.3: Mean rankings of the chemical and food \& drink industry in Great Britain and the Netherlands on the competitive items

The value chain of the chemical industry can roughly be divided into two parts. The upstream parts consist of basic chemicals, like hydrocarbons or polymers, and the downstream parts, such as plastics products or detergents, use the basic chemicals as input for their own production processes. About 30\% of the demand for chemical products is consumed in this way (APPE, 1993), pointing to a relatively high degree of vertical integration in the European chemical industry. The fact that a large part of basic chemical production is consumed by in-company downstream parts explains the relatively low importance of fierce advertising and brand names lat least compared to the food \& drink sector in which most of the customers are outside the company's domain). It could also provide an explanation for the fact that clients - again compared to food \& drinks - have less information about the market, since their suppliers belong to the same company. The high degree of vertical integration explains the relatively easy entry into distribution channels since for basic chemicals these are then within the same company. Due to the 
industrial mature of the market, fierce advertising is also an unlikely method for communicating for the remaining $70 \%$ of demand from external customers. In a market where real value - in terms of specifications of the product - is more important than perceived value - in terms of quality or uniqueness created through advertising - personal selling is preferred (Hutt \& Speh, 1986). Next to the high level of vertical integration, the industry also has a high level of concentration. The ten largest EC manufacturers represented $48.6 \%$ of total industry turnover in 1990 (APPE, 1993). The formation of larger chemical groups is necessary to internationalize operations and to implement global strategies in order to be competitive on a worldwide basis (CEFIC, 1993). This high level of concentration, however, could also lead to higher switching cost for clients, since their bargaining power decreases. Furthermore, a likkely explanation for higher switching cost in the chemical industry compared to the food \& drink sector is the nature of the product. Customers rely on the technical - often unique - specifications of the supplies for their own production processes and products. To change the specifications of the input possibly results in changes in the production process and/or product. Due to the capital intensiveness of production, these changes will not easily be made and, therefore, provide a barrier to switch from one supplier to another. The observation that productive capacity has been increased in chemicals seems to apply especially to bulk chemicals, as excess capacity in this area is substantial (APPE, 1993). Bulk chemicals have been suffering from a decline in demand and production due to the cyclical slow-down in the European economies in 1990 and 1991 1Commission of the European Communities, 1993). As a result of the nature of the product in this segment, price and service are the two only factors that a chemical company can exploit to differentiate itself from competitors. Demand in specialty chemicals has remained more steady, although caution is in order since major customer industries, like motor vehicles, agriculture, textiles and construction, suffered from falling demand in 1992 (CEFIC, 1993a).

The companies in the European food \& drink industry face increasing bargaining power of commercial outlets. This explains why they indicate that entry into distribution channels is difficult. Fierce advertising and a large emphasis on brand names are marketing strategies to deal with these difficulties. Because when pull strategies (Kotler, 1991) are pursued - primarily in the form of advertising and consumer promotion directed at end users - the bargaining power of the intermediaries is diminished by surpassing them. The advertising directed at the end users also provides the customers with a relatively large amount of information on the market. Since the European food \& drink industry is still relatively fragmented. the largest ten companies accounted for $18 \%$ of the total food $\&$ drink sales in 1989 (Commission of the European Communities, 1993) - the switching cost for clients are not very high. Furthermore, clients are not tied to use of products by high capital investments. Since substitutes are located relatively easy, no real 
barriers to switching suppliers exist.

Results question 3

Question 3: Does the competitive environment significantly differ in the chemical industry in Great Britain and the Netherlands?

Within the chemical industry, companies in Great Britain and the Netherlands only significantly $(p=0.0082)$ differ on the extent to which the sector is subsidized by the government. The companies in the British chemical industry perceive a higher presence of government subsidies in their sector than their Dutch counterparts.

\section{Results question 4}

Question 4: Does the competitive environment significantly differ in the food \& drink industry in Great Britain and the Netherlands?

Within the food \& drink industry, there are significant ( $p<0.05$ ) differences between the two countries on five of the seventeen competitive items. The mean rankings of the countries are presented in Table 3.4 bellow. All these competitive items relate to Porter's (1980) threat of potential entrants. This threat appears to be lower in the Netherlands than in Great Britain. The reason behind this can be sought in the relative attractiveness in terms of value added in the food \& drink sector in both countries. Value added appears to correlate positively with the concentration ratio of the food industry (Commission of the European Communities, 1993). The food \& drink industry in Great Britain, where the sector is rather concentrated with UK companies accounting for more than $70 \%$ of the turnover of the first ten EC companies, has the second largest value added in Europe 117,431 million ECU in 19911. Many large companies pursue conglomerate strategies there. The Dutch industry on the other hand, suffers from a much lower value added (5,694 million ECU in 1991) because the market is too small to establish a significant industry. This difference makes the Dutch food \& drink industry less attractive to enter than the British food \& drink sector.

\begin{tabular}{|l|c|c|}
\hline & Great Britain & The Netherlands \\
\hline A favorable location is important & 3.90 & 8.36 \\
\hline Presence of gowemmentit subsidies & 9.50 & 4.36 \\
\hline Limited growth in the industry & 4.00 & 8.29 \\
\hline Easy acoass raw materials important & 3.30 & 8.79 \\
\hline Availability of resources to resist entry & 3.30 & 8.79 \\
\hline
\end{tabular}

Table 3.4: Mean rankings of the British and Dutch food \& drink industry 


\subsection{The competitive environment in Great Britain and the Netherlands in two dimensions}

In Section 3.2 differences in the competitive environment over industries and countries are described at the item level. Although this provides an insight into the relative importance of industries or countries, further analysis of how these individual competitive items are related is necessary in order to test relationships between the competitive environment and strategy. The testing of the relationship between the competitive environment and strategy is the subject of Section 3.6. The current section reports the results of an attempt to detect underlying dimensions in the set of competitive items by applying PRINCALS ("PRINcipal Component Analysis by means of alternating Least Squares"). The analysis suggests that two environmental dimensions emerge from the data that together explain $69 \%$ of the variance among the seventeen items (the complete analysis for Great Britain and the Netherlands is presented in Appendix Cl. The dimensions are interpreted as follows.

A high positive score on dimension 1 implies that

the brand names of products is one of the main determinants in the buying process of clients;

to compete it is not important to have a favorable location of production and/or sales facilities;

the sector is strongly subsidized by the government;

from a competitive point of view it is important to possess patents on the technologies of the products:"

the buyer has no access to detailed information on demand and prices in the market; and

easy access to raw materials is not important from a competitive point of view.

Dimension 1 mainly refers to items that affect the intrinsic operations of the company in terms of either a more conservative or a more innovative approach to cost control. For example, in a market where brand names are of no importance, no government subsidies can be received and patents play a minor role, but clients are fully informed on market demand and prices and both a favorable location and easy access to raw materials are necessary to compete, companies hardly have any other option than to run their operations as efficiently as possible. Therefore, dimension 1 can be interpreted as a continuum between "drive to cost control" (negative score on dimension 1 ) and "drive to innovate" (positive score on dimension 1).

A high positive score on dimension 2 implies that

there is no aggressive use of advertising in the industry;

it is easy to enter distribution channels; and 
clients will encounter high costs when they switch to a competing supplier. Dimension 2 mainly refers to items that affect the necessity for well-developed marketing and sales activities. In a market where clients must pay a high price for switching from one supplier to another, where products can be distributed without difficulty and where the advertising intensity is low, the need for sophisticated marketing seems to be absent. Dimension 2 therefore can be interpreted as a continuum between "drive to sophisticated marketing" Inegative score on dimension 2) and "drive to minimize marketing efforts" (positive score on dimension 2).

How the companies in the different industries are positioned on the two dimensions is presented in Figure 3.2.

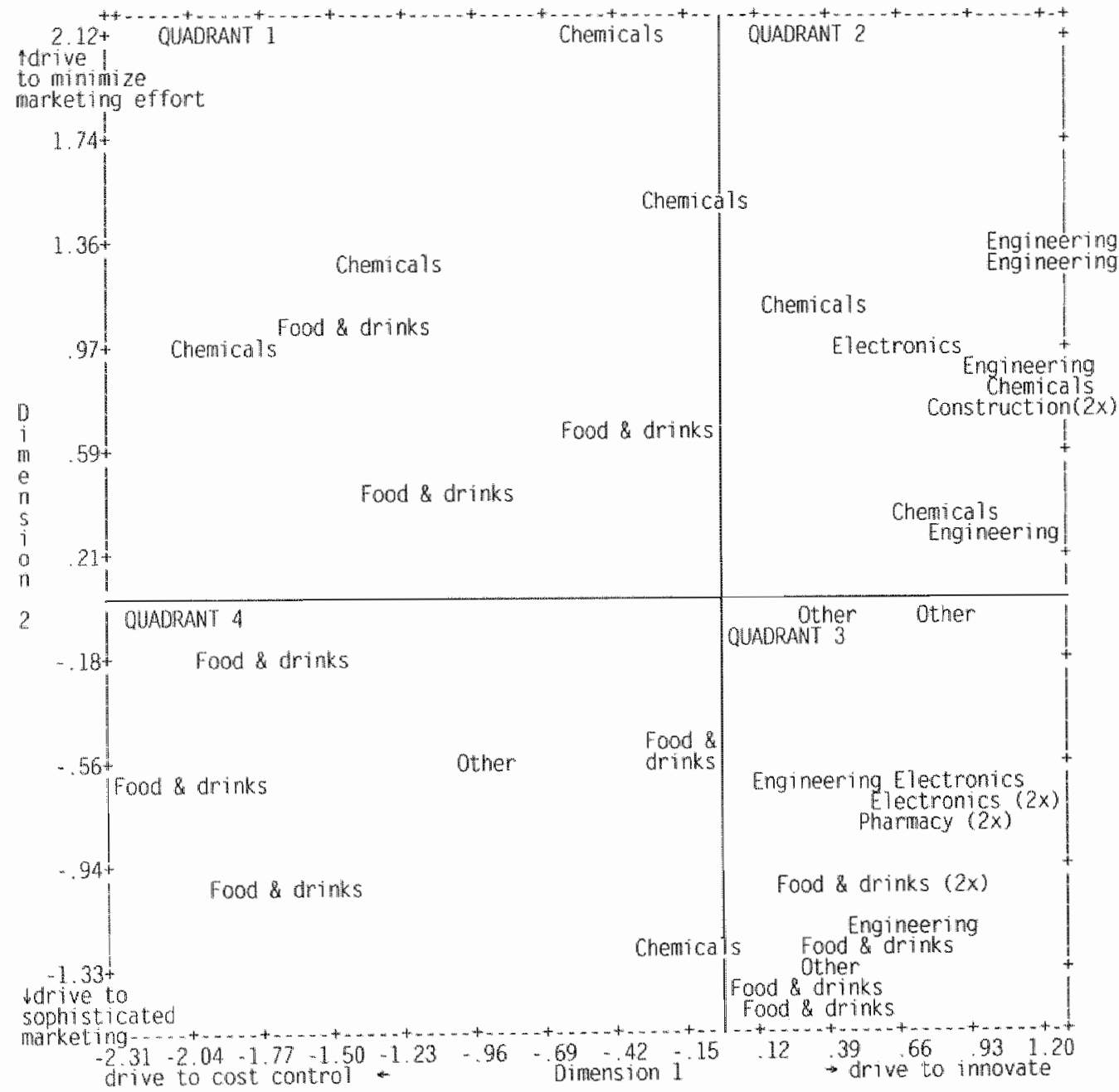

Figure 3.2: Object scores labeled by industry classification 
The observation in Figure 3.2 that companies in some of the industries seem to group together while in other industries they seem to be very different from each other, is supported by the results of Kruskal-Wallis tests on the separate environment items and the different industries performed in Section 3.2. When the separate items of dimension 1 are taken together, weighed by their loading factor, a Kruskal-Wallis test on the object scores by industry indicates that the industries still differ significantly from each other $(p=0.0033)$. The mean rankings on dimension 1 for construction, engineering and pharmacy are high, indicating that the drive to innovate is strongest in those industries. Food \& drinks and chemicals obtain the lowest mean rankings, indicating that the drive for cost control is largest here. This result confirms intuition.

From Table 3.2 in Section 3.2 it appears that, for the items of dimension 2 , the food \& drink and pharmacy industry receive an overall ranking that is similar on all ittems. This is also true for the chemical, construction and engineering industries, whille electronics mostly ranks in between. This is supported by a Kruskal-Wallis test for differences between the industries on dimension 2 (significance level of $p=0.04951$. Due to the orientation towards the final consumer of the electronics, food \& drink and pharmaceutical industries, the drive to sophisticated marketing is not surprising. Also, the drive to minimize the marketing effort in the chemical, construction and engineering industry confirms intuition.

The analysis above may give the impression that although significant differences between industries exist, the situation within industries is fairly homogeneous. As can be concluded from Figure 3.2, however, this is hardly ever the case. To investigate these differences further, Figure 3.2 is divided into four quadrants. These can be interpreted as follows.

11) In guadrant 1 the companies operate in an environment with a drive to cost control and a drive to minimize marketing efforts. Four chemical companies and three food $\&$ drink firms can be found in this region. The chemical companies in this quadrant are expected to be mainly producers of commodity chemicals. These are standard products made by a number of suppliers to meet the same market specifications (Heino, 1993). The food \& drink companies are allso expected to be mainly active in generic, basic need products like dairy products or sugar. For most of the chemical and food \& drink companies present in this quadrant - except the two chemical companies located closest to the drive to innovate - this is indeed the case. On the basis of their environmental characteristics these companies most likely adopt ellements of Porter's (1980) cost leadership strategy, Miles \& Snow's (1978) defender strategy or Miller's (1987b) dimension of conservative control.

(2) The environment in quadrant 2 consists of a drive to innovate and a drive to minimize marketing efforts. Three chemical, four engineering, two 
construction companies and one electronics firm operate in this quadrant. For example, the chemical companies operating here are expected to produce specialty chemicals. Although demand in specialty chemicals has remained more steady than in bulk chemicals, an increasing focus on higher value added and more specialized market segments is necessary in order to maintain a competitive position. One way chemical companies try to achieve this is through product innovation. In 1990 the chemical companies in the $\mathbb{E C}$ spent about $4.8 \%$ of their turnover on R\&D/Commission of the European Communities, 1993). So, to operate in this quadrant, companies must have features of innovative differentiation, seeking to achieve a competitive advantage purely by the quality or intrinsic uniqueness of the product. Due to the industrial nature of the market, a perceived rather than real value is hard to obtain. Neither Miles \& Snow (1978) nor Miller (1987b) or Porter (1980) explicitly recognize a strategy with these features. Although Porter's (1980) differentiation strategy would fit into this quadrant, he does not distinguish between different bases of differentiation. Also Miles and Snow's (1978) prospectors and Miller's (1987b) complex innovators incorporate only some of the features mentioned here.

3) Companies operating in quadrant 3 must balance a drive to innovate with a drive for sophisticated marketing. Three electronics, five food \& drink, two engineering and two pharmaceutical companies can be found here. It is expected that these companies operate in a consumer market where product differentiation and creating brand loyalty is equally important. An example could be consumer electronics. The technical life cycle of products is

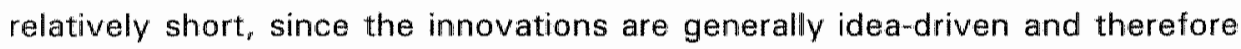
hard to protect (Shibata, 1993). This makes market timing and intelligence plus the creation of brand loyalty of vital importance to the firm (Williams, 19921. Another example are the food \& drink firms where almost the same situation applies. They operate in fast-moving markets, like parts of frozen food and confectionery, where uniqueness is created through combining strong brands with development of new or existing products. Miles \& Snow (1978) define these companies as pursuing a prospector strategy, while they could also have features of Porter's differentiation profile. Miller (1987b) calls strategies pursued in this type of environment complex innovation.

(4) The environment in quadrant 4 is characterized by a drive for cost control in combination with a drive for sophisticated marketing. One chemical company and four food \& drink companies are situated here. They are all expected to manufacture consumer products for which they can create a perceived added value through marketing, while at the same time keeping their cost low through cost control (Miller \& Friesen, 1986a \& 1986b). The market is expected to be less dynamic than in quadrant 3 with less emphasis on 
development of new or existing products. According to Porter (1980), companies operating under these conditions run the risk of ending up in a stuck in the middle position by trying to combine two mutually exclusive strategies. Miles \& Snow (1978) allow some combined emphasis on cost control and sophisticated marketing in the companies pursuing an analyzer strategy. Additionally, however, they distinguish between stable and dynamics domains in which the company emphasizes different aspects, while in quadrant 4 a true combined effort is found. Miller (1987b) calls this type of generic strategy marketing differentiation (although he does not explicitly recognize a drive for cost controll.

Which strategies are actually pursued in both countries and in the different industries, is presented in Section 3.5. How the different strategies pursued are distributed over the two dimensions and if (strategic) groups within the industries exist, is discussed in Sections 3.6 and 3.7. Section 3.4, in which some data on strategy-making in Great Britain and the Netherlands are presented, serves as an introduction.

\subsection{Formalization of strategy making}

Although the strategy-making process is not the subject under study here, some aspects of this process in the British and Dutch companies are presented to provide a context for the data on the content of strategies in Section 3.5. Miller (1987a) summarizes the existing literature on strategy-making with reference to three key issues or dimensions. The first dimension he distinguishes is the extent to which the process occurs in a rational, purposefully planned manner. The second dimension refers to the degree of interaction that exists between different groups within the organization. Finally, the third dimension is the level of assertiveness or risk-taking when making strategic decisions. The data collected with the questionnaire of the International Organizationall Observatory (Appendix B) shed some light on the first two dimensions.

Based on the questionnaire data the strategy-making process seems rather rational in the Netherlands as well as in Great Britain. More specifically, in the Netherlands all of the companies interviewed (14) have their strategy stated in a formal plan and of the 24 British companies that were interviewed, $83 \%$ has a formal strategic plan. This strategic plan is prepared at the company level in $96 \%$ of the British and all of the Dutch companies. A strategic plan at the business unit level is avallable in $33 \%$ of the British and in $36 \%$ of the Dutch companies. Finally, a strategic plan for the functional level is present in $50 \%$ of the Dutch and in $21 \%$ of the British companies. The results are summarized in Table 3.5 . 
Two additional indicators of a methodological, rational planning process are the extent to which theoretical concepts are used to establish the strategic plan and the extent to which data are systematically collected as input for the planning process. The product life cycle concept is employed in $43 \%$ of the Dutch and $50 \%$ of the British companies, the technological life cycle also in $43 \%$ of the Dutch and $33 \%$ of the British companies, and portfolio matrices (such as the Boston Consulting Group matrix) in $57 \%$ of the Dutch and $50 \%$ of the British companies. These results are summarized in Table 3.6. The application of theoretical concepts is thus almost equally popular in Great Britain and the Netherlands.

\begin{tabular}{|l|c|c|}
\hline & The Netherlands $i n=14)$ & Great Britain $(n=24)$ \\
\hline Formal strategic plan: & $100 \%$ & $83 \%$ \\
\hline on company level & $100 \%$ & $96 \%$ \\
\hline on SBU lovel & $36 \%$ & $33 \%$ \\
\hline on functional level & $50 \%$ & $21 \%$ \\
\hline
\end{tabular}

Table 3.5: Formal strategic planning in the Netherlands and Great Britain in percentage of companies

\begin{tabular}{|l|c|c|}
\hline Theoretical concepts used as input & Great Britain & The Netherlands \\
\hline Product life cycle & $50 \%$ & $43 \%$ \\
\hline Tachnological life cycle & $33 \%$ & $43 \%$ \\
\hline Portfolio matrices & $50 \%$ & $57 \%$ \\
\hline
\end{tabular}

Table 3.6: Percentage of companies using theoretical concepts as input for strategic planning

Finally, the majority of companies interviewed in Great Britain and the Netherlands systematically collects data on competitors (Great Britain, 100\%; the Netherlands, $86 \%$ ), customers (Great Britain, $96 \%$; the Netherlands, $71 \%$ ), markets (the Netherlands, 86\%), suppliers (Great Britain, 83\%; the Netherlands; 64\%), and economic trends (Great Britain, $79 \%)$. A summary of the results is presented in Table 3.7. In the Netherlands these data are mainly collected by internal staff (in $64 \%$ of the companies), in Great Britain the data are obtained by internal staff and from publicly avallable sources (in $92 \%$ of the companies). The British companies were also asked whether the gathered data are analyzed regularly. The vast majority $(79 \%)$ indicated that this is indeed the case (regularly was defined as monthly by $58 \%$ of the companies). The degree of interaction also seems to be relatively high in both countries, because the number of hierarchical levels involved in the strategy formulation process is at least two in $64 \%$ of the Dutch companies 
and in $54 \%$ of the British companies. In $17 \%$ of the British companies also a third level is involved. This is the case in $21 \%$ of the Dutch companies.

Summarizing it could be concluded that the planning process in the Dutch as well as in the British sample occurs in a relatively rational and interactive manner.

\begin{tabular}{|l|c|c|}
\hline Collection of data on: & Great Britain & The Nethertands \\
\hline competitors & $100 \%$ & $86 \%$ \\
\hline customers & $96 \%$ & $71 \%$ \\
\hline markets & $?$ & $86 \%$ \\
\hline suppliers & $83 \%$ & $64 \%$ \\
\hline economic trends & $79 \%$ & $?$ \\
\hline
\end{tabular}

Table 3.7: Percentage of companies systematically collecting data

\subsection{Generic strategies pursued in Great Britain and the Netherlands}

There are many ways in which the generic (i.e., non-specific) strategies that companies pursue can be characterized (see Chapter 2, for example: Miles \& Snow, 1978; Porter, 1980; Miller \& Friesen, 1986a; Miller, 1987b; Herbert \& Deresky, 1989; and Morrison \& Roth, 1992). The two typologies that received most attention are the ones developed by Miles \& Snow (1978) and Porter (1980). These two typologies are also used in the Netherlands and Great Britain. In the Netherlands the companies are classified according to Porter (1980) and in Great Britain according to Miles and Snow (1978). Self-typing, combined with investigator inference in Great Britain, was used in both countries to identify the strategy pursued (Snow \& Hambrick, 1980). The main advantage of this approach is that it captures the manager's perceptions about the current intended strategy. Since the managers were asked to classify the strategies for their most important product lines in the business unit they run, they can be considered experts. The questions that the respondents were asked are presented in $A p p e n d i x \mathbb{B}$.

Porter (1980) distinguishes four basic strategy profiles: overall cost leadership, overall differentiation, cost focus and differentiation focus. With a cost leadership strategy the company thrives for the lowest-cost position in the industry. With a differentiation strategy the firm tries to achieve a competitive advantage by creating uniqueness in its products. The focus strategy, where the company targets a specific segment in the market, can be combined with either of the above. Whenever a company does not make a choice between the generic strategies, it is according to Porter (1980) - considered to be stuck in the middle. Of the companies interviewed in the Netherlands $8 \%$ pursues an overall differentiation strategy, $8 \%$ a strategy of overall cost leadership, $8 \%$ a strategy of cost focus and $38 \%$ a 
differentiation focus strategy. Finally, 38\% tries to combine cost leadership, differentiation and focus targeted at a particular segment in the market. This is summarized in Table 3.8 .

\begin{tabular}{|c|c|c|c|c|c|}
\hline & Cost leadership & Diferentiation & $\begin{array}{l}\text { Cost } \\
\text { focus }\end{array}$ & $\begin{array}{l}\text { Differentiation } \\
\text { focus }\end{array}$ & $\begin{array}{l}\text { Differentiation } \\
\text { cost leadership } \\
\text { and focus }\end{array}$ \\
\hline \hline The Netherlands & $8 \%$ & $8 \%$ & $8 \%$ & $38 \%$ & $38 \%$ \\
\hline
\end{tabular}

Table 3.8: Generic strategies pursued in the Netherlands

It is noteworthy that a relatively large percentage of Dutch firms pursues a combined strategy of cost leadership, differentiation and focus. To see if they are actually stuck in the middle, as Porter 11980 ) would assume, a Kruskal-Wallis test is performed on the performance of the companies. Two separate performance measures were used, one objective (reported profit as a percentage of sales) and one subjective (perception of profitability compared to other national competitors in the same sector). On neither of these performance measures a significant difference between the strategies appeared, suggesting that there is no reason to assume that simultaneous pursuit of generic strategies automatically leads to inferior performance. This is consistent with a contingency view of Porter's strategies (Hill, 1988; and Murray, 1988) where it is argued that the efficacy of strategies is dependent on factors associated with the structure of the industry. For example, the firms operating in an environment with a drive to cost control - which stems from structural characteristics of the industry - and a drive to sophisticated marketing - which is based on the nature of the consumer market - are likely to adopt a combination strategy of cost leadership and differentiation (see Section 3.6 on this).

Miles and Snow (1978) also distinguish four basic forms of strategy: defenders, prospectors, analyzers and reactors. Defenders thrive for efficient production and distribution by creating a stable sett of products and customers. Prospectors look for and exploit new product and market opportunities while avoiding long-term commitments to a single technological process. Analyzers combine aspects of the defender and the prospector. They locate and exploit new product and market opportunities while simultaneously maintaining a base af traditional products and customers. The reactors, finally, cannot deall with the environment in a stable and consistent way, which results in bad performance.

In Great Britain 29\% of the companies can be characterized as defenders, $50 \%$ as analyzers, $21 \%$ as prospectors and, finally, none as reactors (Table 3.9 ). 


\begin{tabular}{||c|c|c|c|c|}
\hline & Defenders & Prospectors & Analyzers & Reactors \\
\hline Great Britain & $29 \%$ & $21 \%$ & $50 \%$ & $0 \%$ \\
\hline
\end{tabular}

Table 3.9: Generic strategies pursued in Great Britain

Although the emphasis in the typologies of Porter and Miles \& Snow is different, similarities can be traced as well. Segev (1989) compared the strategy types of Miles \& Snow with Porter's generic strategies on two dimensions: internal consistency and pro-activeness. His results suggest that Miles \& Snow"s defender is closest to Porter's cost focus, the prospector to differentiation, the analyzer to differentiation and cost focus and the reactor to the stuck in the middle position. Apart from the strategy of stuck in the middle, which appears to be almost identical to the reactor type, none of the strategies completely overlaps. They should rather be seen as forming a continuum on the dimension of pro-activeness. Therefore, here the different typologies are not combined into one typology for further analysis. This results in the following distribution of strategies over the different industries (Table 3.10). How these strategies differ over the environmental dimensions developed in Section 3.3, is discussed in Section 3.6.

\begin{tabular}{|c|c|c|c|c|c|c|c|c|}
\hline & Chemicals & Construction & Engineering & Electronics & $\begin{array}{c}\text { Food } \\
\& \\
\text { drinks }\end{array}$ & Pharmacy & $\begin{array}{l}0 \\
t \\
h \\
e \\
r\end{array}$ & $\begin{array}{l}T \\
0 \\
t \\
a \\
1\end{array}$ \\
\hline $\begin{array}{l}\text { Strategy } \\
\text { It }\end{array}$ & 1 & 0 & 2 & 0 & 0 & 0 & 1 & 2 \\
\hline $\begin{array}{l}\text { Strategy } \\
2^{2}\end{array}$ & o & 0 & 0 & 0 & 1 & 0 & 0 & 1 \\
\hline $\begin{array}{l}\text { Strategy } \\
3^{3}\end{array}$ & 2 & o & 0 & 0 & 2 & o & 0 & 4 \\
\hline $\begin{array}{l}\text { Strategy } \\
4^{4}\end{array}$ & 1 & o & 0 & 0 & o & 0 & 0 & 1 \\
\hline $\begin{array}{l}\text { Stratiegly } \\
5^{5}\end{array}$ & 0 & a & o & 0 & 4 & 0 & 1 & 5 \\
\hline $\begin{array}{l}\text { Strategy } \\
6^{e}\end{array}$ & 0 & 0 & 2 & 2 & 0 & 1 & 0 & 5 \\
\hline $\begin{array}{l}\text { Strategr } \\
y^{7}\end{array}$ & 2 & 1 & 2 & 0 & 0 & 1 & 1 & 7 \\
\hline $\begin{array}{l}\text { Strategy } \\
8^{8}\end{array}$ & 1 & 1 & 2 & 2 & 5 & 0 & 1 & 12 \\
\hline Total & 7 & 2 & 6 & 4 & 12 & 2 & 4 & 37 \\
\hline
\end{tabular}

$\begin{array}{ll}\text { 1 Differentiation } & 5 \text { Differentiation, cost leadership and focus } \\ \text { Cost leadership } & 6 \text { Prospector } \\ 3 \text { Differentiation focus } & 7 \text { Defender } \\ 4 \text { Cost focus } & 8 \text { Analyzer }\end{array}$

Table 3.10: Generic strategies in different industries 
3.6 The relationship between the competitive environment and generic strategy in Great Britain and the Netherlands: different strategies in different environments?

To test whether the different strategies pursued in Great Britain and the Netherlands significantly differ over the environmental dimensions, a Kruskal-Wallis test was performed. The results for dimension 1 are presented in Table 3.11 .

\begin{tabular}{|c|c|c|c|c|}
\hline & Mean rank & Cases & \multicolumn{2}{|l|}{ Strategy } \\
\hline & 11.00 & 1 & \multicolumn{2}{|l|}{ Differentiation } \\
\hline & 3.50 & 2 & \multicolumn{2}{|l|}{ Cost leadlership } \\
\hline & 7.00 & 5 & \multicolumn{2}{|c|}{ Differentiation focus } \\
\hline & 6.00 & 1 & \multicolumn{2}{|l|}{ Cast focus } \\
\hline & 7.00 & 5 & \multicolumn{2}{|c|}{ Focus/cost leadership/differentiation } \\
\hline & 31.21 & 7 & \multicolumn{2}{|l|}{ Defender } \\
\hline & 23.00 & 12 & \multicolumn{2}{|l|}{ Analyzer } \\
\hline & 26.50 & 5 & \multicolumn{2}{|l|}{ Prospector } \\
\hline Total cases & Chi-square & Significance & $\begin{array}{l}\text { Corrected for ties } \\
\text { Chi-square }\end{array}$ & $\begin{array}{l}\text { Corrected for ties } \\
\text { Significance }\end{array}$ \\
\hline 38 & 26.4095 & .0004 & 26.4182 & .0004 \\
\hline
\end{tabular}

Table 3.11: Kruskal-Wallis test on dimension 1 by strategy pursued

Dimension 1 does significantly (at $p=0.0004$ ) distinguish between the different strategies. Companies operating in an environment with a drive to innovate la high positive score on dimension 1$)$ seem to follow either a prospector, analyzer or defender strategy. Especially the latter result is rather surprising, since defenders were expected to operate in an environment with a drive to cost control. However, recent research in high-tech industries (Dvir, Segev \& Shenhar, 1993) indicates that, although particularly prospectors are expected to be dependent on technological progress, it is the group of defenders on which the influence of this technological progress is greater and more fruitful in the short and long run. Since prospectors scan technological opportunities more widely, their short-term results might suffer. While defenders, on the other hand, are more conservative in their investment, but focus on technologies directly related to their line of business. The companies pursuing a cost leadership. cost focus or combination strategy of cost leadership, differentiation and focus are operating in an environment with a drive to cost control, as was expected.

The results for dimension 2 are presented in Table 3.12. 


\begin{tabular}{|c|c|c|c|c|}
\hline & Mean rank & Cases & \multicolumn{2}{|l|}{ Strategy } \\
\hline & 37.00 & 1 & \multicolumn{2}{|l|}{ Differentiation } \\
\hline & 31.50 & 2 & \multicolumn{2}{|l|}{ Cost leadership } \\
\hline & 27.00 & 5 & \multicolumn{2}{|c|}{ Differentiation focus } \\
\hline & 34.00 & 1 & \multicolumn{2}{|l|}{ Cost focus } \\
\hline & 16.40 & 5 & \multicolumn{2}{|c|}{ Focus/cost leadership/differentiation } \\
\hline & 21.21 & 7 & \multicolumn{2}{|l|}{ Defender } \\
\hline & 13.42 & 12 & \multicolumn{2}{|l|}{ Analyzer } \\
\hline & 16.10 & 5 & \multicolumn{2}{|l|}{ Prospector } \\
\hline Total cases & Chi-square & Significance & $\begin{array}{l}\text { Corrected for ties } \\
\text { Chisquare }\end{array}$ & $\begin{array}{l}\text { Corrected for ties } \\
\text { Sigmificance }\end{array}$ \\
\hline 38 & 13.4110 & .0627 & 13.4154 & .0626 \\
\hline
\end{tabular}

Table 3.12: Kruskal-Wallis test on dimension 2 by strategy pursued

The strategies pursued by the companies also significantly differ on dimension 2 . When the environment dictates a minimization of marketing effort, strategies of cost leadership, cost focus and overall differentiation appear. The latter result is rather surprising, unless differentiation is mainly achieved through technical innovation (the companies in quadrant 2). The prospector, analyzer and combination strategy of cost leadership, differentiation and focus appear in an environment with a drive to sophisticated marketing. Especially for the prospectors this outcome is not surprising, since a strong marketing orientation is one of their distinctive competencies. Ordinally arrayed in terms of their degree of marketingrelated competencies, Miles \& Snow's (1978) strategic types could be stated as prospector $>$ analyzer $>$ defender $>$ reactar (Conant, Mokwa \& Rajan Varadarajan, 1990).

A summary of the results on the environment-strategy relationship is presented in Table 3.13 .

\begin{tabular}{|l|l|}
\hline Environmertal dimensions & Strategies \\
\hline Drive to innovate & Prospector, Analyzer, Defender \\
\hline Drive to cost control & $\begin{array}{l}\text { Cost leadership, Cost focus, Combination of tocus, } \\
\text { cost leadership and differentiation }\end{array}$ \\
\hline Drive to sophisticated marketing & $\begin{array}{l}\text { Prospector, Analyzer, Combination of focus, ciost } \\
\text { leadership and differentiation }\end{array}$ \\
\hline Drive to minimize marketing effort & Cost leadership, Cost Focus, Overall differentiation \\
\hline
\end{tabular}

Table 3.13: Strategies in different environments 


\section{7 (Strategic) groups based on the environmental dimensions?}

A strategic group is defined as a group of firms in an industry pursuing a similar strategy in terms of decisions made on certain strategic dimensions (Porter, 1980 . These dimensions include, for example, product quality, cost position, verticall integration and production technology. A first attempt is made here to examine whether on the basis of the environmental dimensions previously defined, groups of companies can be detected following similar strategies. The industries chosen for analysis are the chemical and food $\&$ drink industry for reasons outlined in Chapter 2. Nonetheless, the attempt can be but tentative, since a firm's strategy - and thus its strategic group - can hardly be cllassified on environmental dimensilons alone. Furthermore, the strategic information included in this analysis is limited to the current intended strategy as identified by the companies (Section 3.5). So, more information is necessary on implemented patterns of resource allocation in the areas of production technology, organization and HRM to truly identify strategic groups (Dess and Davis, 1984). In Chapters 4, 5 and 6 production technology and HRM are examined in more detail and related to the findings of this chapter. Classification based on environmental dimensions is a first step, however, towards a better understanding of potential strategic grouping in the chemical and food \& drink industry. Since managers ${ }^{\prime}$ perceptions of the competitive environment play an important part in shaping their strategies, these may play an important part in potential strategic groupings as well (Reger \& Huff, 1993).

Figure 3.3 displays how the strategies pursued in the chemical and food \& drink industry in Great Britain and the Netherlands are positioned on the two enwironmental dimensions. Cluster analysis was performed to examine a potential underlying group structure. As suggested by many authors (Morrison \& Roth, 1992; and Reger \& Huff, 19931, a combination of a non-hierarchical method Partitioning around Medoids (Kaufman and Rousseeuw, 1990) - and a hierarchical method - SPSS Single Linkage (SPSS-X User's Guide, 1988) - was used. To determine the final cluster solution on the basis of the non-hierarchical method, the silhouette coefficient was examined for a two, three, four and five-cluster solution. The silhowette coefficient provides an indication of the average within-group dissimilarity compared to the between-group dissimilarity. The higher the coefficient, the smaller the within-group dissimilarity compared to the betweengroup dissimilarity, which indicates a clear cluster structure in the data. For the hierarchical method, a large break in the squared Euclidean distance and inspection of the dendograms were used as decision criteria.

For the food \& drink industry, a three-cluster solution appeared to be optimal, whereas the companies in the chemical industry were better classified in a fourcluster solution. The clusters are graphically displayed in Figure 3.3. The complete analysis is presented in Appendix D. The results for each industry will be discussed 
below. The numbers of the companies correspond to a short company description provided in Appendix A.

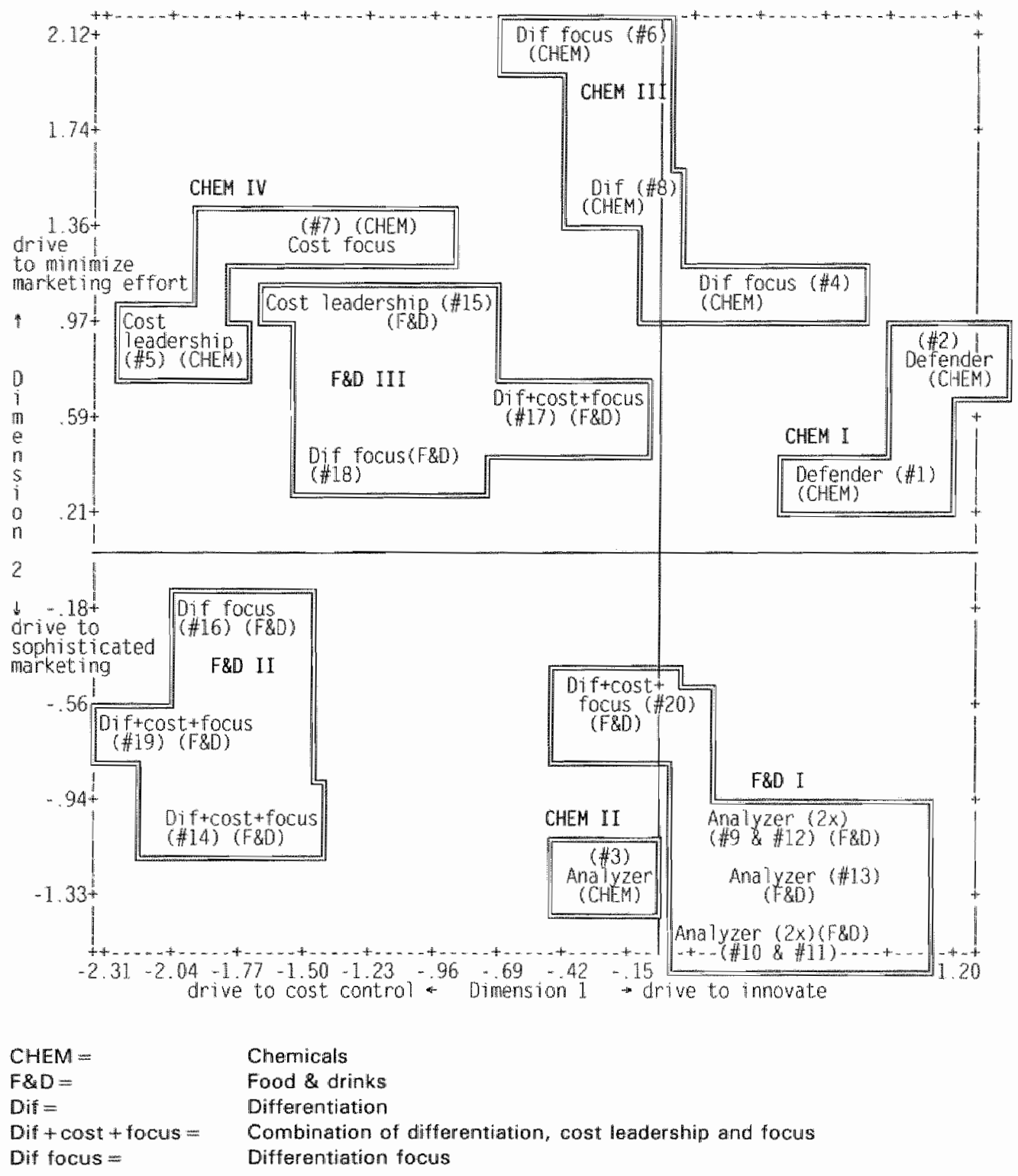

Figure 3.3: Object scores labeled by strategy pursued 


\section{Food \& drinks}

The three cluster-solution found here has an average silhouette coefficient of 0.63 . According to Kaufman and Rousseeuw 11990). who provide a subjective interpretation based on experience, this indicates that a reasonable structure has been found. The exact categories they distinguish are presented in Appendix D. A hierarchical clustering algorithm (single linkage) was also applied to check if the same structure would appear again. This method also identified the same three cllisters as the optimal solution.

The first, strongest, food \& drink cluster contains five firms - 9, 10, 11, 12 and 13 - pursuing an analyzer strategy and one firm - 20 - with a combination strategy of differentiation, cost leadership and focus. The second food \& drink cluster consists of two firms - 14 and 19 - with a combination strategy of differentiation, cost leadership and focus and one firm - 16 - pursuing a differentiation focus strategy. The third, weakest, food \& drink cluster contains three firms pursuing strategies of differentiation focus - company 18 -, cost leadership - company 15 - and a combination of all three - company 17 respectively. The weakness of the third cluster results from the relatively high within-cluster variance compared to the between-cluster variance. These results are summarized in Table 3.14.

\begin{tabular}{|c|c|}
\hline Chster & Strategies pursued \\
\hline $\mathbb{1}$ & $\begin{array}{l}\text { * five analyzers, companies } 9,10,11,12 \text { and } 13 \\
\text { * one combination strategy of differentiation, cost leadership and focus, company } 20\end{array}$ \\
\hline$\| 1$ & $\begin{array}{l}\text { Iwo combination strategies of differentiation, cost leadership and focus, companiesi } \\
14 \text { and } 19 \\
\text { one differentiation focus strategy, company } 16\end{array}$ \\
\hline 111 & $\begin{array}{l}\text { one combination strategy of differentiation, cost leaclership and focus, company } 17 \\
\text { one cost leadership strategy, company } 15 \\
\text { one differentiation focus strategy, company } 18\end{array}$ \\
\hline
\end{tabular}

Table 3.14: Three c/usters in the food \& drink industry based on environmental dimensions

Because the content of each cluster seems, at first sight, a rather diverse collection of strategies, an ANOVA-procedure examined group differences on the individual competitive iterns to enhance the interpretation of each cluster. Results from this procedure are reported in Table 3.15. Inspection of this table creates the impression that within the food \& drink industry the importance of a brand name, the amount of information customers have about the market and the switching cost for clients are almost equally lunjimportant to all firms. 


\begin{tabular}{|c|c|c|c|c|}
\hline $\begin{array}{l}\text { Environmental wariables } \\
(H=\text { incomect to } 4=\text { correct }\end{array}$ & Chuster 1 & Chuster II & Choster III & F-value \\
\hline \multicolumn{5}{|l|}{ Dimension 1} \\
\hline Brand name is important & 2.8 & 2.3 & 2.3 & 0.55 \\
\hline A favorable location is important & 1.8 & 3.0 & 2.3 & 3.54 \\
\hline Presence of government subsidies & 2.7 & 1.0 & 1.7 & $4.50^{*}$ \\
\hline Patents are important & 2.2 & 1.0 & 1.7 & $3.54 *$ \\
\hline Customer's have information about the market & 2.5 & 3.0 & 2.7 & 1.04 \\
\hline Easy access to raw materials is important & 1.7 & 3.0 & 2.7 & $9.56 *$ \\
\hline \multicolumn{5}{|l|}{ Dimension 2} \\
\hline Switching cost for cllients are high & 1.2 & 1.0 & 1.3 & 0.50 \\
\hline Advertising is fierce & 2.5 & 2.3 & 1.0 & $5.13 *$ \\
\hline Entry in distribution channels is difficult & 2.0 & 3.0 & 1.3 & $28.69 * *$ \\
\hline
\end{tabular}

* Significance of difference in maans, $p<0.1$

* Significance of difference in means, $p<0.05$

* * Significance of difference in means, $p<0.001$

Table 3.15: Three clusters in food \& drinks: means of individual environmentel items

The differences between the clusters on the remaining items of dimensions 1 and 2 , however, should result in different strategies. Comparison of the item differences between the clusters also yields another observation: the Dutch and British firms tend to group together by country. Food \& drink cluster I contains British firms - 9, 10, 11, 12 and 13 - with analyzer strategies and only one Dutch firm - 20 - pursuing a combination strategy. The food \& drink clusters II and III consist of only Dutch firms. This is not surprising since three of the items - the importance of a favorable location, the presence of government subsidies and the importance of easy access to raw materials - that distinguish the three clusters from one another also significantly distinguish the competitive environment in the Netherlands from the one in Great Britain (Table 3.4). So, based on the cluster structure it could be concluded that within the food \& drink industry the drive to innovate is much stronger in Great Britain than in the Netherlands. In the remaining analysis however, the differences between countries do not receive particular attention. The country difference is treated as a difference between the competitive environment on dimension one (that also happens to distinguish between countries).

The companies in food \& drink cluster I operate in an environment with a relatively strong drive to innovate and, because of the difficulty to enter distribution channels and fierce advertising, a strong drive to sophisticated marketing. The 
strategies they follow appear to be similar, although the position of firm 20 pursuing a combination strategy of differentiation, cost leadership and focus is an exception that needs to be investigated further - especially since the silhouette coefficient for this organization appears to be low, with its closest neighbor being cluster III (Appendix D). What is also in need of further investigation is that in this kind of environment, on theoretical grounds, more praspectors than analyzers were expected (Section 3.3).

Food \& drink cluster $\|$ is completely situated in an environment with a strong drive for cast control and a drive to sophisticated marketing. To find a firm pursuing a differentiation focus strategy (company 16) in this cluster is surprising, especially since a rather strong drive for cost control is present. Although a strategy of marketing differentiation would be expected in this cluster because of the drive to sophisticated marketing, on theoretical grounds (see Section 3.3) it should be combined with some sort of cost emphasis as well. The differentiation focus firm (company 18) operating in food \& drink cluster 111 , where a drive for cost control is combined with a drive to minimize marketing efforts, is even more questionable. Due to the nature of the environment any type of pure differentiation seems to be impossible. Technical differentiation is not feasible because of the drive for cost control and marketing differentiation is unattainable because of the drive to minimize the marketing effort. Although the possibility exists that these firms are in the process of shifting their strategic positions or that the strategy actually implemented differs from the strategy formally stated, further investigation of other strategic dimensions is necessary to search for satisfactory explanations. This will be done in the Chapters 4,5 and 6 of this book.

The fact that the combination strategy of cost leadership, differentiation and focus appears in all three clusters is possibly not as odd as it might seem at first glance. That is, the emphasis on the different elements of the combination strategy could differ from cluster to cluster. For example, it is likely that in food \& drink cluster I differentiation receives more weight compared to cost leadership, while in food \& drink cluster 111 cost leadership is more important. This hypothesis too will be developed further in subsequent chapters.

The difference on dimension 2 between food $\&$ drink cluster $I$ and $I I$ on the one hand and cluster III on the other is also made by Sutton (1991), who distinguishes between markets where sunk costs are exogenous - such as the investment in building a plant - and markets where sunk costs are endogenous such as the investment in increasing the value of products in the eyes of the consumer. The first type of market can be divided into the homogeneous goods industry and horizontal product differentiation markets. The second type of market are advertising-intensive industries (for an elaborate explanation of Sutton's (1991) theory, see Boone \& Van Witteloostuijn, 1995). Then, cluster IIII should consist of firms operating in homogeneous goods industries ffor example, sugar or 
consumption milk). Because these products are physically homogeneous, it is expected that price competition is tough and differentiation, unless through regional segmentation of markets, impossible. This is true for the companies our sample, since two dairy producers and one sugar producer operate in this cluster. Firms in food \& drink cluster I and || operate in more advertising-intensive industries. The firms in our sample operating in these clusters produce liquor, beer, confectionery, frozen foods, and dairy products (milk and desserts).

\section{Chemicals}

The four-cluster solution found in chemicals has an average silhouette coefficient of 0.40 , which according to Kaufman and Rousseeuw (1990) indicates that the structure is weak and could be artificial. So, also here a hierarchical clustering algorithm (single linkage) was applied to check if the same results would appear. The hierarchical clustering confirms the non-hierarchical result (see Appendix D for the complete analysis). The findings on the cluster structure in the chemical industry are almost the opposite from the findings in the food \& drink sector. Here, the between-cluster variance compared to the within-cluster variance is rather weak, but inspection of the content of the clusters suggests a very consistent, clear pilcture (Table 3.16). This may suggest a discrepancy between the stated strategy and the strategy actually implemented. Furthermore, also in the chemical industry the British and Dutch firms group together. Chemical clusters I and II contain only British firms and chemical clusters III and IV only Dutch firms. But, as in the food \& drink sector, this difference is merely treated here as a difference between competitive environments rather than as a difference between countries.

\begin{tabular}{|c|c|}
\hline Cluster & Strategies pursued \\
\hline 1 & * two defendors, companies 1 and 2 \\
\hline !I & * one analyzer, company 3 \\
\hline$|\||$ & $\begin{array}{l}\text { * two diffarentiation rocus } \text {, companies } 4 \text { and } 6 \\
\text { * one differentiation. company } 8\end{array}$ \\
\hline IV & $\begin{array}{l}\text { *ne cost leadership, company } 5 \\
\text { one cost focus, company } 7\end{array}$ \\
\hline
\end{tabular}

Table 3.16: Four clusters in the chemical industry based on environmental dimensions

To gain additional insights into the differences between the chemical clusters, an ANOVA-procedure examined group differences on the individual competitive items. The difference in mean scores between the chemical clusters on the individual environmental items are summarized in Table 3.17. 


\begin{tabular}{|c|c|c|c|c|c|}
\hline $\begin{array}{l}\text { Environmental warrables } \\
11=\text { incorrect to } 4=\text { correct }\end{array}$ & Cluster & $\begin{array}{l}\text { Chuster } \\
\text { It }\end{array}$ & $\begin{array}{l}\text { Chuster } \\
\text { WW }\end{array}$ & $\begin{array}{l}\text { Cluster } \\
\text { IV }\end{array}$ & F-value \\
\hline \multicolumn{6}{|l|}{ Dimension 1} \\
\hline Brand name is mportant & 2.0 & 3.0 & 1,7 & 1.0 & 1.41 \\
\hline A favorable location is important & 2.0 & 2.0 & 1.7 & 3.0 & $4.42^{*}$ \\
\hline Presence of govermment subsidies & 3.0 & 3.0 & 1.0 & 1.0 & $\mathrm{~N}: \mathrm{A}$ \\
\hline Patents are important & 2.5 & 3.0 & 2.7 & 1.0 & $4.95^{*}$ \\
\hline Customers have information about the market & 1.0 & 3.0 & 2.0 & 2.5 & $9.33 *$ \\
\hline Easy accessi to raw materials is important & 1,5 & 2.0 & 2.3 & 2.5 & 0.97 \\
\hline \multicolumn{6}{|l|}{ Dimension 2} \\
\hline Switching cast for clients are high & 2.0 & 1.0 & 2.3 & 1.5 & 1.95 \\
\hline Advertising is fierce & 1.0 & 2.0 & 1.0 & 1.0 & $\mathbb{N A}$ \\
\hline Entry in distribution channels is difficult & 1.5 & 2.0 & 1.0 & 1.5 & $1.17^{*}$ \\
\hline
\end{tabular}

* Significance of difference in means, $p<0.1$

* Significicance of difference in means, $p<0.05$

NA Not avallable, no variance within clusters so measures not calculated

Table 3.17: Four clusters in chemicals: means of individual environmental items

The weak cluster structure is mainly due to the composition of chemical cluster II and III. Cluster II is a singleton and contains the only analyzer - company 3 - among the chemical firms. As can be seen in Figure 3.3, it is the odd one out because of its score on drive to sophisticated marketing. Why this firm holds such an extreme position needs to be further examined by looking at its production technology and its HRM policy in Chapters 4,5 and 6. A possible explanation, however, could be that it operates in one of the downstream chemical sectors where a strong identification with final customers' needs, beyond just the technical specifications of the product, is mecessary (APPE, 1993). This is supported by the analysis presented in Tablle 3.17. On dimension 1 this firm perceives patents as very important and feels that customers have a lot of information about the market. Furthermore on dimension 2 they perceive entry in distribution channells as significantly more difficult than the other chemical clusters. All this indicates that this company operates in a consumer rather than an industrial market. Chemical cluster III contains one firm - company 8 - pursuing an overall differentiation strategy and two firms - companies 4 and 6 - with a differentiation focus strategy. Company 4 is not clearly positioned in this cluster, since it balances between this chemical cluster and cluster 1 (Appendix D). This firm bordering on two clusters may be a transient firm (Reger \& Huff, 1993), with a strategy changing from one position to another based on a changing perception of the competitive environment. It is typical that this firm considers making use of new technologies to be an 
important element of its strategy. Chemical cluster 1 consists of two defenders companies 1 and 2 - operating in an environment with a drive to innovate and a drive to minimize marketing effort. Since in a mature industry such chemicals, unit cost is the key factor to competitiveness and robustness (APPE, 1993), the extremely high score of the defenders on drive to innovate seems to be odd. Either the companies in this cluster currently hold a competitive cost position and have shifted their focus to advanced research and development programs to meet customer needs or they focus on innovation while still suffering from a lack of cost competitiveness, which has placed sections of Western European industry at a competitive disadvantage (APPE, 1993). Finally, in chemical cluster IV there is one firm - company 7 -following a cost focus and one firm - company 5 - pursuing a cost leadership strategy. These companies are expected to manufacture commodity products which are undifferentiated by product performance and technology, the latter being readily avallable in all regions of the world (APPE, 1993). One of the few competitive options they therefore have, is to keep their unit cost as low as possible. This may also explain that a favorable location is more important to this cluster than for the others (Table 3.17), since this can significantly diminish transportation costs. The companies in this chemical cluster are indeed producers of commodities, since they manufacture olefines, chlorine and caustic soda.

It is rather surprising that the cost leadership and cost focus firm are situated almost opposite from the defenders on dimension 1. This result suggests that the environment and strategy is very different for both groups, while previous research (Segev, 1989) indicated that especially the cost focus and defender strategies closely resemble each other. Other strategic variables, like size, market share and resource allocations in production technology and $\mathrm{HRM}$, need to be examined as well for these two groups to provide an explanation.

\subsection{Conclusion}

In this chapter the relationship between the competitive environment and generic strategies is examined for the sample of Dutch and British firms. Two environmental dimensions are derived from statements describing the competitive environment. Dimension 1 describes a continuum between a " drive to cost. control" and a "drive to innovate". Dimension 2 portrays a continuum between a "drive to sophisticated marketing" and a "drive to minimize the marketing effort". These environmental dimensions indeed discriminate significantly between the different strategies pursued. Companies operating in an environment with a drive to innovate follow either a prospector, analyzer or defender strategy. Strategies of cost leadership, cost focus or a combination strategy of cost leadership, differentiation and focus operate in an environment with a drive to cost control. 
When the environment dictates a minimization of marketing effort, strategies of cost leadership, cost focus and overall differentiation appear. In an environment with a drive to sophisticated marketing, companies pursue a prospector, analyzer or combination strategy of cost leadership, differentiation and focus.

To gain more insight into the relationship between the competitive environment within the chemical and food \& drink industry and strategy, a first attempt was made to analyze potential strategic grouping on the basis of the two environmental dimensions. Although clusters in both the chemical and food \& drink industry could be identified, the results are, as yet, rather unsatisfactory and leave many questions unanswered. For sake of clarity and to guide further research in Chapters 4,5 and 6 , these questions are summarized below:

1. When other key strategic dimensions - such as production technology and HRM policies - are examined, does then a clarification of cluster structure as described in Section 3.7 result?

2. When it does not, is the strategy formally stated by the companies different from the strategy actually implemented?

3. When a difference between the stated and implemented strategy does exist, does this difference result from:

a) a real mismatch between the perception of the environment, the generic strategy and the actual implemented policies? In this case performance should suffer because a 'misfit' exists and potential reactors (Miles \& Snow, 1978) and firms 'stuck in the middle' (Porter, $1980)$ could be identified; or

b) the method of data collection in terms of level of specificity concerning the questions measuring the generic strategy pursued? Since the strategy questions only defined broad strategy categories, respondents may either not have understood the question or may have given a desired but untrue answer. In this case implemented strategies are consistent with environmental conditions and, since a fit is present, performance should not suffer. 


\section{CHAPTER 4}

\section{THE TECHNOLOGICAL SETTING}

\section{IN RELATION TO THE COMPETITIVE ENVIRONMENT AND GENERIC STRATEGIES}

This chapter examines specific strategies regarding manufacturing technology which determine the technological setting (Miller, 1988). The technological setting, which embodies choices about the acquisition, development and deployment of technology, is of central importance to the competitive position of organizations (Adler, 1989; and Wheelwright \& Hayes, 1985). Although this is commonly recognized in the literature, the topic has hardly received any empirical validation (Parthasarthy \& Sethi, 1993; and Zahra \& Covin, 1993). An attempt at this is made in this chapter.

Section 4.1 provides a brief overview of existing literature on the technologyenvironment-strategy relationship to put the analysis in this chapter into context. Section 4.2 then analyzes the manufacturing technologies of the companies interwiewed in terms of Woodward (1965). Section 4.3 studies if and how recent developments in automation alter the manufacturing function. A refinement off Woodward's (1965) typology is proposed that incorporates the new advanced manufacturing technologies. In Section 4.4 the relationship between manufacturing technology and the competitive environment is discussed, while Section 4.5 explores the relationship between manufacturing technologies, generic strategies and the environment. Support is provided for the hypothesis that coherent environment strategy - technology policy 'gestalts' exist. Section 4.6, finally, presents a conclusion. Furthermore, like in the previous chapter, special attention is paid to the chemical and food \& drink industry. The relationships discussed in this chapter are summarized in Figure 4.1.

4.1 Manufacturing technologies, strategies and competitive environment: a brief selection of existing research

The notion that manufacturing should be considered an integral part of the generic strategy of the organization dates back to the work of Skinner (1969) and has only received more attention since (Nemetz \& Fry, 1988; ltami \& Numagami, 1992; and Parthasarthy \& Sethi, 1992). However, although manufacturing technology is now recognized as an important factor in building a competitive advantage (Porter, 1985), 


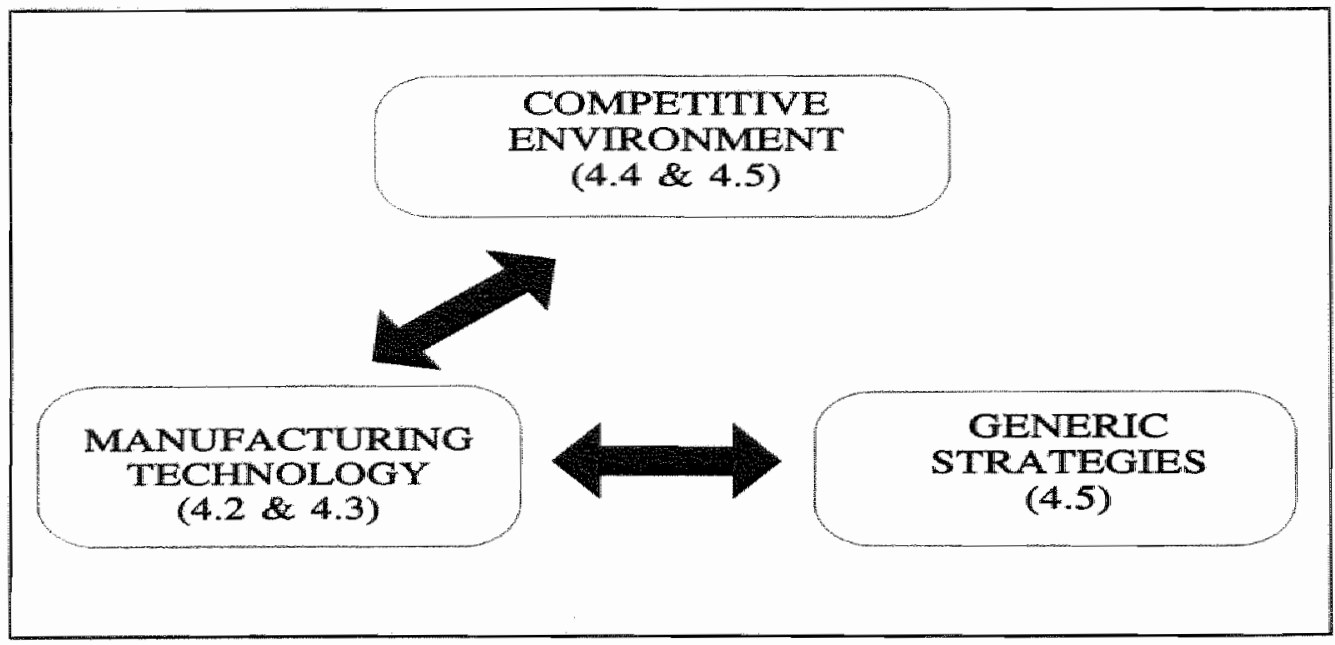

Figure 4.1: The relationship between the technological setting, the competitive environment and generic strategies

much of the work focuses on conceptual development rather than empirical research (Schroeder, 1990; and Zahra \& Covin, 1993). Kotha and Orne (1989) developed an illustrative manufacturing structure typology, based on a review of manufacturing and strategy literature, that incorporates three dimensions. The first dimension - process structure complexity - consists of three underlying variables: the level of mechanization, the level of systemization and the level of interconnection. The level of mechanization is the extent to which the production process is automated. The level of systemization refers to the way in which the production process is controlled, while the level of interconnection represent the degree of integration between the different production stages. This dimension incorporates the work on technology by Woodward (1965) that will be elaborated upon in Section 4.2. The second dimension - product line complexity - refers to end-product complexity, variety of final product, individual product volume and end product maturity and thus describes the type and variety of the product lines of the company. Finally, the third dimension which refers to organization scope variables such as geographic manufacturing scope, geographic market focus, vertical integration, customer-market scope and scale. This dimension is closely linked to typologies of generic strategies (see also Chapter 3). Similar to the second and third dimension Kotha \& Orne (1989) distinguished, is a taxonomy of manufacturing strategies developed by Miller \& Roth (1994). They define three distinct types of manufacturers that position themselves differently on market differentiation, defined as the perceived requirement to distinguish oneself by its products and services from competitors, and market scope, defined as the magnitude of the customer base.

The introduction of advanced manufacturing technologies has significantly 
changed pracess structure since Woodward (1965) and created possibilities to increase the type and variety of products as well as organization scope. Advanced manufacturing technologies and their impact on traditional typologies of process structure is discussed in more detail in Section 4.3.

Examples of empirical studies are those by Parthasarthy \& Sethi (1993) and Zahra \& Covin (1993). Parthasarthy \& Sethi (1993) examine the relationship between strategy, structure, flexible automation and performance. Their sample consists of 87 single product firms or business units that operate in the U.S. machinery, motor vehicles, aircraft and electronic equipment industries. Their findings suggest that flexible automation combined with strategies which exclusively emphasize cost leadership result in inferior performance. Related to this finding it is also suggested that mechanistic structures in combination with flexible automation result in lower performance than organic structures. Furthermore - consistent with organic structures - flexible automation in combination with skill diversity and team approaches lead to superior performance. Zahra \& Covin (1993) study the relationship between business strategy, technolagy policy and firm performance in a sample of 103 US dominant or single business firms in diverse mature industries. Their results also reveal that business strategy moderates the relationship between technology policy and performance. Furthermore they suggest that firms whose strategies are primarily based on technological competencies can run the risk of technological myopia.

Sections 4.4 and 4.5 of this chapter build on the findings of these two empirical studies above by assuming that a fit between manufacturing technology, generic strategy and competitive environment contributes to achieving superior performance.

\subsection{Manufacturing technology in the British and Dutch firms}

As was described in the introduction of this book, the typology used to classify the production systems of the companies in the British and Dutch sample is developed by Woodward (1965). She was one of the first to empirically investigate the influence of technology on the structure of an organization in a sample of one hundred British firms. Originally, the firms were classified into eleven categories of production systems, which are presented in Table 4.1 in increasing order of technical complexity. To facilitate analysis she collapsed the eleven categories into three broader ones. These three categories are:

1. Unit and small batch production;

2. Large batch and mass production; and

3. Continuous process production.

As can be seen in Table 4.1 , some of the original eleven categories fall into more than one broader type. Production systems 1 to 5 can be classified as unit and small batch production, 4 to 8 as large batch and mass production and, finally, categories 7 to 11 
as continuous process production.

\begin{tabular}{|c|c|c|}
\hline \multicolumn{2}{|c|}{ Production system } & Broad categories \\
\hline 1. & Production of units to customers" requinements & \multirow{3}{*}{ Small batch and unit production } \\
\hline 2. & Production of protatypies & \\
\hline 3 & Fabrication of large equipment in stages & \\
\hline 4. & Production of small batches to customersi orders & \multirow{2}{*}{$\begin{array}{l}\text { Small batch and unit production } \\
\text { Large batch and mass production }\end{array}$} \\
\hline 5 & $\begin{array}{l}\text { Production of standandized comportents in large batches } \\
\text { subsequently assembled diversely }\end{array}$ & \\
\hline 6. & Production of large batches & \\
\hline 7 & Production of large batches on assembly lines & \multirow{2}{*}{$\begin{array}{l}\text { Large batch and mass production } \\
\text { Continuous process production }\end{array}$} \\
\hline 8 & Mass production & \\
\hline 9. & $\begin{array}{l}\text { Process production, subsequently prepared for sale by } \\
\text { standardized production methods }\end{array}$ & \multirow{3}{*}{ Continuous process production } \\
\hline 10. & Intermittent production of chemicals in batches & \\
\hline 11. & $\begin{array}{l}\text { Continuous flow production of liquids, gases and } \\
\text { crystalling substances }\end{array}$ & \\
\hline
\end{tabular}

- Cattegory of small batch and unit production

-....... Catemary of large batch and mass production

. Category of continuous process production

Table 4.1: Woodward's (1965) classification of production systems

A set of categories similar to Woodward's (1965) eleven, though more limited, was used in the Netherlands and Great Britain to describe the production systems (see Appendix B). In order to be able to compare the data from the two countries, however, some modifications prior to analysis had to be made. The British companies were classified according to one of the following six production types: unit production, small batch production, production in large batches of standardized components subsequently assembled diversely, mass production with no frequent product changes, mass production with frequent product changes and continuous process production. The Dutch companies were allawed to choose a combination of these production systems because they were asked, on a scale from 1 (correct) to 4 (incorrect), to assess whether each of these six production systems provided an accurate description of their own manufacturing technology. The resulting distribution over the six production systems in the two countries is presented in Table 4.2. 


\begin{tabular}{|c|c|c|c|c|}
\hline \multicolumn{2}{|c|}{ Production system } & \multirow{2}{*}{$\frac{\text { Great }}{\text { Britan }}$} & \multirow{2}{*}{$\begin{array}{l}\text { Thei } \\
\text { Netherlands } \\
0\end{array}$} & \multirow{2}{*}{ Total } \\
\hline 1. & Unit production & & & \\
\hline 2. & Small batch production & 3 & 2 & 5 \\
\hline 3. & $\begin{array}{l}\text { Piroduction in large batches of sitandardized components } \\
\text { subsequently assembled diversely }\end{array}$ & 8 & 0 & 8 \\
\hline 4. & Mass production with no frequent product changes & 3 & 0 & 3 \\
\hline 5 & Mass production with trequent product changes & 4. & 0 & 4 \\
\hline 6. & Continuous process production & 1 & 0 & 1 \\
\hline 7. & $\begin{array}{l}\text { Production in large batches of standardized components } \\
\text { subsequenty assembled diversely with features of small } \\
\text { batch and continuous process production }\end{array}$ & 0 & q & 1 \\
\hline 8. & $\begin{array}{l}\text { Production in large batches of standardized components } \\
\text { subsequently assembled diversely with also features of } \\
\text { mass production with no frequent product changes. }\end{array}$ & 0 & 1 & 1 \\
\hline 9. & $\begin{array}{l}\text { Mass production, with no frequent product changes in } \\
\text { parts of the process and parts with frequent product } \\
\text { changes. }\end{array}$ & 0 & 1 & 1 \\
\hline 0 & $\begin{array}{l}\text { Mass production with features of production in large } \\
\text { batches of standardized components as well as } \\
\text { continuous process production }\end{array}$ & 0 & 1 & 1 \\
\hline 11. & $\begin{array}{l}\text { Continuous process production combined with mass } \\
\text { production with no frequent product changes. Aspects of } \\
\text { the process also have features of mass production with } \\
\text { frequent product changes }\end{array}$ & 0 & 2 & 2 \\
\hline 12. & $\begin{array}{l}\text { Conthinuous process production with features of mass } \\
\text { production with no frequent product changes }\end{array}$ & 0 & 4 & 4 \\
\hline
\end{tabular}

Table 4.2: Distribution of the British and Dutch companies over the different manufacturing technologies

As can be concluded from an inspection of Table 4.2, no comparison is possible between Great Britain and the Netherlands based on this categorization. The companies are therefore reassigned to the three broad categories of unit and small batch production, large batch and mass production and continuous process production in a way that is consistent with Woodward's (1965) classification:

1. Unit and small batch production consists of the categories 1 and 2 of Table 4.2.

2. Large batch and mass production comprises the categories $3,4,5,7,8$ and 9 of Table 4.2 .

3. Continuous process production holds the categories $6,10,11$ and 12 of Table 4.2.

This results in the following distribution of production systems over the different industries and the different countries (Table 4.3). 


\begin{tabular}{|l|l|l||c|c|c|c|c|c|c|}
\hline & NL & $G B$ & Chemicals & Construction & Electronics & Engin & $\begin{array}{l}\text { Food \& } \\
\text { Drinks }\end{array}$ & Pharmack & Other \\
\hline $\mathrm{U}$ & 2 & 8 & 0 & 2 & 2 & 4 & 0 & 0 & 2 \\
\hline $\mathrm{M}$ & 3 & 15 & 3 & 0 & 2 & 2 & 7 & 2 & 2 \\
\hline $\mathrm{P}$ & 7 & 1 & 4 & 0 & 0 & 0 & 4 & 0 & 0 \\
\hline
\end{tabular}

$\begin{array}{ll}U= & \text { Unit and small batch production } \\ M= & \text { Large batch and mass production } \\ P= & \text { Continuous process production } \\ N L= & \text { The Netherlands } \\ G B= & \text { Great Britain } \\ \text { Engin. }= & \text { Engineering }\end{array}$

Table 4.3: Distribution of production systems over countries and industries

The question however arises whether the developments concerning automation of manufacturing technology have rendered the above categorization obsolete. This is discussed in the next section.

\subsection{Developments in manufacturing technology}

Since Woodward's (1965) study, many developments in manufacturing technology have taken place. The effects of automation have received considerable attention because of a growing awareness of the role that technology can play in achieving competitive advantage over competitors (Butler, 1988; Zammuto \& $O^{\prime}$ Connor, 1992; Parthasarthy \& Sethi, 1993; and Zahra \& Covin, 1993). Advanced manufacturing technologies, however, come in a large variety. In this study the following nine types are considered (Meredith, 1987):

1. Computer Aided Design (CAD) is a computerized software package to design new products or modify existing products in considerably less time and with improved quality. Another advantage is that the design function can be directly linked to the manufacturing function (through coupling with CAM or CAPP systems).

2. Computer Aided Engineering (CAE) software assists the engineer while examining and testing design from a structural or engineering point of view. This package is very similar to CAD software.

3. Computer Aided Manufacturing (CAM) encompasses the software to control manufacturing machinery.

4. Computer Aided Process Planning (CAPP) allows for a fast design of the production process.

5. Computer Numerical Control (CNC) is a machine tool that is directly linked to a computer that contrals it. The advantages of $\mathrm{CNC}$ machines are their flexibility 
and their consistent quality.

6. Continuous Process Software (CPS) controls the production process in continuous process production.

7. Flexible Manufacturing Systems (FMS) are a collection of robots or CNC machines that can be employed in a flexible manner.

8. Material Requirement Planning (MRP) is an information system that is used to support the planning of materials.

9. Robots can be very sophisticated and reprogrammable. Moreover, they can have very simplistic abilities. They are usually used in one specific part of the production process.

Whether any of the above advanced manufacturing technologies is implemented in the companies interviewed in the Netherlands and Great Britain is presented in Table 4.4. Also, the results for the chemical and food \& drink industry are included.

\begin{tabular}{|c|c|c|c|c|c|c|}
\hline & $\begin{array}{l}\text { Metherlands } \\
\text { total sample }\end{array}$ & $\begin{array}{l}\text { Great Britain } \\
\text { total sample }\end{array}$ & $\begin{array}{l}\text { Food \& } \\
\text { Drinks, } \\
\text { Ne }\end{array}$ & $\begin{array}{l}\text { Food \& } \\
\text { Drinks, } \\
G B\end{array}$ & $\begin{array}{l}\text { Chemicals. } \\
N L\end{array}$ & $\begin{array}{l}\text { Chemicals } \\
G B\end{array}$ \\
\hline 1. $\mathrm{CAD}$ & 5 & 20 & 2 & 4 & 1 & 3 \\
\hline 2. C.AE & 4 & 13 & 2 & 2 & 1 & 0 \\
\hline 3. CAM & 4 & 14 & 2 & 2 & 1 & 3 \\
\hline 4. C.APP & 3 & $\# 1$ & 2 & 5 & 0 & 1 \\
\hline 5. CNC & 4 & 13 & 1 & 0 & 1 & 2 \\
\hline 6. CPS & 5 & 7 & 2 & 4 & 3 & 2 \\
\hline 7. FMS & 1 & 7 & 0 & 2 & 0 & 1 \\
\hline 8. MAP & 8 & 17 & 4 & 5 & 2 & 1 \\
\hline 9. Mobotsi & 1 & 9 & 0 & 2 & 0 & 1 \\
\hline
\end{tabular}

Table 4.4: Number of companies that implemented advanced manufacturing technologies in the Netherlands and Great Britain

As the results in Table 4.4 suggest, the companies generally employ more than just one advanced manufacturing technology. Furthermore, there are significant differences between the countries with respect to a number of technologies. Mann-Whitney tests on the different technologies by country indicate that significant differences ip < $0.07)$ between the Netherlands and Great Britain exist on four of the nine new technologies. In the British sample, Computer Aided Design and Computer Aided Manufacturing as well as Robots and Flexible Manufacturing Systems are implemented more often than in the Dutch sample. Also, within the chemical and food \& drink industry significant country differences prevail. Within the food \& drink industry, 
Mann-Whitney tests indicate at a significance level of $p<0.03$ that Computer Aided Process Planning and Robots are used more in the British sample than in the Dutch sample. Within the chemical industry. British companies employ Computer Aided design, Computer Aided Manufacturing and Computer Aided Process Planning significantly $(p<0.07)$ more than their Dutch counterparts. These results, at first glance, seem to be consistent with the findings in Chapter 3 , where the clusters that mainly contained British firms appeared on the environmental dimension 'drive to innovate'. Whether this first impression is correct, is the subject of Section 4.4. There, the exact relationship between the manufacturing technology employed and the environmental dimensions will be analyzed.

The adoption of these advanced manufacturing technologies makes technologystrategy relationships more complex in the sense that boundaries between the traditional three technology types are blurred, thereby making combinations between. these types feasible (Adler, 1988; and Nemetz \& Fry, 1988). Traditionally, it was assumed that when technical complexity of the production process increased, the flexibility of the organization decreased. Flexibility, in this context, refers to the ability to respond quickly and efficiently to changes in volume and design (Parthasarthy \& Sethi, 1993). An example of such a relationship where flexibility is assumed to decrease, is the "product-process matrix" developed by Hayes \& Wheelwright (1984). They distinguish four stages of the production process that are very similar to Woodward's (1965) three manufacturing technologies. Subsequently these production process stages link to four stages of product structure. So, unit and small batch production (or jumbled fllow or job shop in Hayes \& Wheelwright's terms) is associated with low volume, low standardization and thus unique products. On the other end of the spectrum, continuous process production appears with high valume, high standardization and therefore the production of commodity products. Large batch and mass production (or, in their terms, disconnected line flow and connected line flow) are situated in between. The matrix implies that firms could only efficiently pursue strategies that lay on the diagonal that was just described. It is exactly this issue of decreasing flexibility associated with increasing technical complexity that the advanced manufacturing technologies can change (Zammuto \& $O^{\prime}$ Connor, 1992). Thereby they provide more strategic manufacturing options for the companies. In other words, the basis of competition in manufacturing is shifting from economies of scale to economies of scope (Jelinek \& Goldhar, 1984): when it becomes feasible to produce a larger variety of products on the same equipment without extra costs, large batch and mass production firms and even continuous process production firms may adopt features of unit and small batch production.

The potential benefits of advanced manufacturing technologies, however, do not come automatically to those firms that implement them (Meredith \& McTavish, 1992). Research has shown that although the majority of firms did gain an increase in productivity by implementing advanced manufacturing technology, only relatively few 
reported an increase in flexibility. In addition, failure in implementation, thereby obviously frustrating the opportunities to gain any benefits, also occurred frequently (Zammuto \& O'Connor, 1992). Although data on implementation were not gathered in our sample, questions on perceived trends in production technology were included. It can be tentatively assumed that when the implementation of new technology is at least somewhat successful, this would be reflected in the companies" perception of their technological enviromment.

To examine whether the firms in our sample which implemented advanced manufacturing technologies (Table 4.4) actually observed significantly different trends in the development of manufacturing technology compared to their non-adopting counterparts, Mann-Whitney tests are performed on a set of statements describing developments in production technology. The complete list of statements is presented in Appendix B. In order to be able to compare the British and Dutch data, conversion of the scales originally used in the Netherlands and Great Britain has taken place. The British original scale ranged from 1 (incorrect description) to 5 (completely correct description). Categories 4 and 5 were combined, thereby eliminating the difference between 'completely correct description' and "correct description'. The Dutch scale was reversed, since it originally measured correct description (1) to incorrect description (4). Significant differences between companies that implemented any of the advanced manufacturing technologies and those that did not, do indeed exist on a number of items (Table 4.5). The dominant change that can be observed over all the advanced manufacturing technologies, except CPS, is that the companies indeed perceive an increase in flexibillity. Noteworthy, however, is that the majority of new manufacturing technologies emphasizes an increase in process rather than product flexibility. An increase in process flexibility pertains to increased control, in the sense of more efficient planning and scheduling of the production process, more efficient usage of materials, less inventory and a more integrated production process, all resulting in time savings and efficiency (Jelinek \& Goldhar, 1984; Meredith, 1987; and Adler, 1988). The only clear exception is Computer Aided Design, since this technology is specifically developed to more efficiently design new products or modify existing ones.

Computer Aided Process Planning, Computer Aided Manufacturing, Computer Numerically Controlled machines, Flexible Manufacturing Systems and Robots thus all lead to an increase in process flexibility. It is only the companies that implemented Computer Aided Design that also emphasize an increase in product flexibility in terms of feasibility of a larger number of design and production variants. In the cases where Computer Aided Engineering or Material Requirement Planning is adopted, process flexibility is underlined next to a decrease in product flexibility, since these companies feell that the products are becoming more and more standardized. A completely different case are the companies that use Continuous Process Software. They perceive an increase in neither process nor praduct flexibility when considering the 
developments in manufacturing technology in their industry.

\begin{tabular}{|c|c|c|}
\hline \multicolumn{2}{|c|}{$\begin{array}{l}\text { Advanced } \\
\text { manufacturing } \\
\text { tectunology }\end{array}$} & \multirow{2}{*}{$\begin{array}{l}\text { Developments perceived in the manufaciuring environment } \\
\text { - the different production and design variants from standard are increasing } \\
(\mathrm{p}<0.09) \\
\text { the management of materials, components and work-in-process is being } \\
\text { decentralized to work stations }(p<0.04) \\
\text { an increasing specialization of sills is needed }(\mathrm{p}<0.02)\end{array}$} \\
\hline 1. & $C A D$ & \\
\hline 2. & CAE & $\begin{array}{l}\text { the time between the initial idea for new products and when they enter } \\
\text { production is becoming shorter }(p<0.08 \text { ) } \\
\text { products are becoming increasingly standardized ( } p<0.04 \text { ) } \\
\text { the inventory of work-imaproces ard of final products is being reduced (p } \\
<0.09 \text { ) } \\
\text { the management of materials, components and work-in-process is being } \\
\text { decentralized to work stations }(p<0.004)\end{array}$ \\
\hline 3. & CAM & $\begin{array}{l}\text { the number of peaple involved un design and development compared with } \\
\text { those in production increases }(p<0.05) \\
\text { an increasing specialization of skills is needed }(p<0.04)\end{array}$ \\
\hline 4. & CAPP & $\begin{array}{l}\text { the production process stages are more closely integrated ( } p<0.01 \text { ) } \\
\text { the management of materials, components and work-in-process is being } \\
\text { decentralized to work stations ( } p<0.09)\end{array}$ \\
\hline 5 & CNC & $\begin{array}{l}\text { the time between the initial idea of new products and when they enter } \\
\text { prodluction is becoming shorter }(p<0.02) \\
\text { the inventory of work-inmprocess and af final products is being reduced ip } \\
<0.03) \\
\text { the production process stages are more closely integrated }(p<0.05) \\
\text { the number of people inwalved in planning and scheduling decreases } \\
\text { compared to those involved in production }(p<0.04) \\
\text { the maragement of materials, components and wark-in-process is being } \\
\text { decentralized to work stations }(p<0.05) \\
\text { due to the increasing complexity of the tasks, the amount of work that is } \\
\text { subcontracted increases }(p<0.08)\end{array}$ \\
\hline 6. & $\mathrm{CPS}$ & $\begin{array}{l}\text { the different production and design variants from standard are decreasing } \\
(p<0.07) \\
\text { the inwentory of work-in-process and final products increases }(p<0.07) \\
\text { due to the increasing complexity of the tasks. the amount of work that is } \\
\text { subcontracted decreases }(p<0,04)\end{array}$ \\
\hline $7_{1}$ & FMS & $\begin{array}{l}\text { The inweintory of work-in-process and final products is being reduced (p< } \\
0.05 \text { ) } \\
\text { the management of materials, components and work-in-process is being } \\
\text { decentralized to work stations. }(p<0.09)\end{array}$ \\
\hline 8 & MAP & $\begin{array}{l}\text { products are becoming increasingly standardized }\{p<0.041 \\
\text { the inventory of work-inmprocess and of final products is: being reduced ip } \\
<0.007) \\
\text { the production process stages are more closely integrated }\{p<0.04\}\end{array}$ \\
\hline 9. & Robotics & $\begin{array}{l}\text { the inventory of work-inuprocess and of final products is being reduced } \| p \\
<0,04) \\
\text { the production process stages are more closely integrated }(p<0.03)\end{array}$ \\
\hline
\end{tabular}

Table 4.5: Significantly different developments in production technology when advanced manufacturing technologies are implemented (in the entire Dutch and British sample) 
Since the implementation of new manufacturing technologies makes a considerable difference in the companies perception of the developments in production technology, questions arise on the homogeneity of Woodward's (1965) traditional three technology groups of unit and small batch production, large batch and mass production and continuous process production. When, for example, half of the firms originally classified in the large batch and mass production group employs any of the new manufacturing technologies, their perception of the production environment will significantly differ from the group of firms that did not implement new technology. From this, one can tentatively conclude that the basis for decisions between these two groups differs substantially and that therefore their (strategic) actions will differ accordingly. To see whether these differences can indeed be observed in our sample which would point to the necessity to further specify Woodward's (1965) technology groups - the implementation of advanced manufacturing technologies within each production type is examined for the firms in the chemical and food \& drink industry. The industry level is appropriate for further examination since the degree and type of automation are dependent on industry-specific developments. A firm's technological advantage is not absolute but relative to the state of the technological development within the industry Parthasarthy \& Sethi, 1992). It appears that within each technology group (there are no firms using unit or small batch production in these two industries) substantial diversity indeed exists with many firms employing even more than one computer technology (Table 4.6).

\begin{tabular}{|c|c|c|c|c|c|}
\hline \multirow[t]{2}{*}{$\begin{array}{l}\text { Now } \\
\text { technology }\end{array}$} & \multicolumn{2}{|c|}{$\begin{array}{c}\text { Chemicals } \\
\text { (total of } 7 \text { companies) }\end{array}$} & \multicolumn{2}{|c|}{$\begin{array}{c}\text { Food \& Drinks } \\
\text { (total of } 11 \text { companies) }\end{array}$} & \multirow[t]{2}{*}{$\begin{array}{l}\text { Total of } 18 \\
\text { companies }\end{array}$} \\
\hline & $\begin{array}{l}\text { Large batch and } \\
\text { mass production }\end{array}$ & $\begin{array}{l}\text { Continuous } \\
\text { pracess } \\
\text { production }\end{array}$ & $\begin{array}{l}\text { Large batah and } \\
\text { mass production }\end{array}$ & $\begin{array}{l}\text { Continuous } \\
\text { process } \\
\text { production }\end{array}$ & \\
\hline 1. $C A_{B} D$ & 2 & 2 & 4 & 2 & 10 \\
\hline 2. CAE & 0 & 1 & 2 & 2 & 5 \\
\hline 3. CAM & 2 & 2 & 2 & 2 & 8 \\
\hline 4. CAPP & 1 & 0 & 6 & 1 & 8 \\
\hline 5. CNC & 3 & $a$ & 4. & 0 & 7 \\
\hline 6. CPS & 1 & 4 & 4 & 2 & 11 \\
\hline 7. FMS & $\pi$ & 0 & 2 & 0 & 3 \\
\hline 8. MRP & 2 & 1 & 6 & 3 & 12 \\
\hline 9. Plobots & 1 & 0 & 2 & 0 & 3 \\
\hline
\end{tabular}

Table 4.6: Number of companies that implemented advanced manufacturing technologies classified by production system 
Table 4.6, therefore, calls for a number of additional analyses. First, the question arises whether a difference in perception of developments in the production environment can be detected between the companies in the food $\&$ drink and chemical industry. Mann-Whitney tests indicate that only one development is perceived significantly different. Companies in the food \& drink sector, contrary to their chemical counterparts, perceive an increase in the number of production planners $(p=0.0147)$. Although the difference between the food \& drink and chemical industry is almost negligible, three significant differences appear when large batch and mass praduction and continuous process production are compared. Companies that employ large batch and mass production perceive a larger increase in product standardization $(p=0.0476)$. a larger decrease in the inventories of work-in-process and final products $(p=0.0078)$ and an increasing integration of the stages of the production process $(p=0.0004)$. This is most likely due to the fact that large batch and mass production firms employ significantly more new manufacturing technologies - CAPP ( $p=0.0505)$, Robotics $(p=0.0790)$. FMS $(p=0.0991)$ and CNC machines $(p=0.0486)$ - than continuous process production companies. This implies that changes in the production environment have a larger impact on those companies that employ large batch and mass production than those that employ continuous process production.

Because of this diversity, the level of flexibility within the three original categories needs to be further specified. Therefore, the advanced manufacturing technologies are first grouped in a systematic way. This is done by viewing them as components of Computer Integrated Manufacturing (Vonderembse \& White, 1991). Computer Integrated Manufacturing combines developments in manufacturing with information technology so as to achieve competitive advantage. It consists of three main components. Engineering design allows the organization to make high quality, specialized designs in a limited amount of time. New manufacturing technologies like CAD, CAE and CAPP fall into this category. Flexible Manufacturing Systems is a coupling of computer and information technology in order to integrate various production functions, and therefore employ new technologies in a flexible manner. Components of Flexible Manufacturing Systems are CAM, CNC machines, CPS and Robots. Finally, the third main component of Computer Integrated Manufacturing is the computerized planning and control system. MRP is an example of this.

These three main components - in addition to the established differences between large batch and mass production and continuous process production in perception of developments in the production environment and in adoption of new manufacturing technologies - provide the basis on which a further specification of the traditional production systems is achieved. The new categories, subsequently discussed, therefore represent different levels of flexibility and integration in the production function. 


\section{Large batch and mass production}

1. "Modified large batch and mass production"

This group contains two firms - one food \& drink and one chemical - that only employ CNC machines in production and/or MRP in their planning function. This group contains the technically least integrated and least flexible firms of the sample.

2. "Automated large batch and mass production"

Two companies - again one food \& drink and one chemical - reside in this group. They both integrated automation of the production function - by CNC machines and/or robots and/or CPS - with automation of the design of the production process through CAPP and automation of the planning function through use of MRP. So compared to the first category, more integration has beem achieved and increasing flexibility becomes feasible.

3. 'Flexible large batch and mass production'

This category contains two food \& drink firms and one chemical company that automated their production process in an integrated way through CAM, the design function with CAD and/or CAE and the planning function with MRP. Two companies also automated the design of the production process with CAPP and two companies use CNC machines and CPS in addition to CAM.

4. 'Innovative large batch and mass production"

The three companies - one chemical and two food \& drinks - in this category are most advanced in terms of level of integration of the three components of computer integrated manufacturing and flexibility. They automated their production function through at least the use of FMS - in addition to CAM andfor CNC machines and/or Robotics and/or CPS - , integrated their design function with at least CAD - in addition to CAPP - and their planning function with MRP. These different levels of integration and flexibility in large batch and mass production should be viewed on a continuum, where a company could progress from category one to four by implementing more new manufacturing technologies that enhance the level of integration and flexibility.

\section{Continuous process production}

1. "Automated planning in continuous process production"

This category contains one food \& drink company that only automated its planning process with MRP. Neither advanced automation of the production nor of the design function was reported.

2. 'Automated design in continuous process production'

Again only one food \& drink company resides in this category. This firm has only automated its design function with CAD, CAE and CAPP without automating the production or planning function.

3. 'Automated continuous process production"

This category contains two chemical companies that just automated their 
production function by implementing CPS. Neither automation of planning nor design was reported.

4. 'Flexible continuous process production'

Four companies - two chemical and two food \& drink - can be found in this category. In addition to CPS, they also employed CAM in production. Two companies also automated their planning function with MRP and two companies automated their design function with $C A D$ and/or CAE.

The different levels of integration and flexibility in continuous process production cannot all be viewed on a continuum, since the first three categories represent the automation of just one function of computer integrated manufacturing. If a continuum had to be composed, the first three categories would be on one side and the fourth category on the opposite, indicating that a company can progress from automation of just one function to a more integrated whole. The fact that in continuous process production a lesser variety of automation methods is found, is not surprising. Since advanced manufacturing technologies offer possibilities for process integration and parts variety, the impact on continuous process production - where process integration is already achieved to a large extent and parts variety is thus not really permitted - is limited.

This classification bears some resemblance to the traditional division between fixed and flexible automation (Buffa \& Sarin, 1987). In fixed automation on the one hand, the product is designed first while the automated system is utilized to produce this product as efficiently as possible. The first categories of 'modified large batch and mass production' and 'automated continuous process production' are closest to fixed automation, since they have automated only parts of the production process. Flexible automation, on the other hand, is aimed at machine integration, where each automated part of the production process is programmed to perform several integrated functions. So, design is linked to production as well as to planning and control. Companies in the categories of "innovative large batch and mass production" and, although to a lesser extent, 'flexible continuous process production' provide examples of flexible automation. The other categories of 'automated large batch and mass production' and 'flexible large batch and mass production' are added because a firm's technology does hardly ever fall in either of the extreme categories, but is better described using a continuum between fixed and flexible automation (Parthasarthy \& Sethi, 1992). One important assumption underlying this classification however has to be made explicit. In applying these categories to the companies, assumptions as to the manufacturing objectives are imposed: companies in the first two large batch and mass production categories and the third continuous process production category emphasize development of the production process, whereas firms in the 'innovative large batch and mass production" and in the 'flexible continuous process production' categories have the ability to concentrate on development of the production process as well as on development of products. 
The manufacturing technologies of the firms in the chemical and food 8 drink industry can now be reclassified according to these eight categories which incorporate next to the traditional division in large batch and mass production or continuous process production, also the adoption of advanced computerized manufacturing technologies (Table 4.7).

\begin{tabular}{|l|c|c|c|c|c|c|c|c|}
\hline \multirow{2}{*}{ Industry } & \multicolumn{4}{|l|}{ Large batch and mass praduction } & \multicolumn{3}{|c|}{ Cantinuous process production } \\
\cline { 2 - 9 } & Mad. & Aut. & Flex. & inno. & $\begin{array}{l}\text { Aut. } \\
\text { planning }\end{array}$ & $\begin{array}{l}\text { Aut. } \\
\text { design }\end{array}$ & Aut. & Flex. \\
\hline Chemicals & 1 & 1 & 1 & 1 & 0 & 0 & 2 & 2 \\
\hline Food \& Drinks & 1 & 1 & 2 & 2 & 1 & 1 & 0 & 2 \\
\hline
\end{tabular}

Mlod = modified Flex. $=$ flexible

Aut. = automated Inno. $=$ innovative

Table 4.7: Manufacturing technologies in chemical and food \& drink firms further specified

The following section examines the relationship between manufacturing technology the traditional as well as the refined classification - and the competitive environment.

\subsection{The technological setting and the competitive environment}

Although it is assumed in the literature that the technological setting in terms of the manufacturing technology is related to the strategies of the organization and thus to the competitive environment, this relationship has in general not been the subject of a large body of empirical literature (Parthasarthy \& Sethi, 1993; Zahra \& Covin, 1993). This Section 4.4 focuses on the features of the competitive environment in the entire sample as well as in the British and Dutch food \& drink and chemical industry in specific, and Section 4.5 goes into the linkages with generic strategies.

In Chapter 3 the competitive environment of the companies in our British and Dutch sample was described in terms of two dimensions that were derived by applying PRINCALS to a set of competitive items. Dimension 1 describes a continuum between a drive to cost control and a drive to innovate, while dimension 2 represents a continuum between a drive to minimize the marketing effort and a drive to sophisticated marketing. To gain an understanding of the type of relationship between the competitive environment and manufacturing technology, a Kruskal-Wallis test is performed on the environmental dimensions by the three broad categories of manufacturing technology (Woodward, 1965) present in the entire sample. At a significance level of $p=0.0018$, dimension 1 distinguishes between the manufacturing technology categories. Unit and small batch production operate in an environment with a drive to innovate, whille continuous process production companies 
can be found in an environment with a drive to cost control. Large batch and mass production firms fall in between with a tendency towards a drive to innovate. This is consistent with the notion that unit and small batch production tends to be associated with a technical emphasis on product development, whereas continuous process production is linked to a technical emphasis on process development (Nemetz and Fry, 1988). In turn, an emphasis on product development is associated with innovative behavior and an emphasis on process development with cost control (Zahra \& Covin, 1993). Furthermore, since the manufacturing technology in continuous process production is most complex and requires heavy capital investment, a commitment to production of a product in bulk, economies of scale and cost control become crucial. The findings concerning large batch and mass production are not consistent with the literature because this production type traditionally tends to be associated with a technical emphasis on process efficiency (Nemetz \& Fry, 1988). The combination of process efficiency and moving into the direction of an environment with a drive to innovate could however be the result of the implementation of advanced manufacturing technologies (Section 4.3). On dimension 2, unit and continuous process firms are located in an environment where a drive to minimize the marketing effort dominates, while large batch and mass production firms operate in an environment with a stronger drive to sophisticated marketing (at $p=0.0032$ ). Although especially the relationship between this dimension and unit and small batch production may seem odd, Woodward (1965) found that the most critical function in the manufacturing cycle of unit and small batch firms is development rather than marketing or production. Because the firms produce at customers' orders, they attend to their marketing before production even begins. The development function is so strongly emphasized because an idea rather than a product is sold. So, when the product is eventually produced, marketing has become unnecessary. The findings are summarized in Table 4.8.

\begin{tabular}{|c|c|c|c|}
\hline \multicolumn{2}{|c|}{ Envirommental dimerision } & \multicolumn{2}{|c|}{ Manufacturing technology } \\
\hline & Drive to imnovate & & $\begin{array}{l}\text { Unit and smiall batch production } \\
\text { Large batch and mass production }\end{array}$ \\
\hline 2. & Drive to cost control & 1 & Continuous process production \\
\hline 3. & Drive to sophisticated marketing & 1. & Large batch and mass production \\
\hline 4. & Drive to minimize marketing effort & $\begin{array}{l}1 \\
2\end{array}$ & $\begin{array}{l}\text { Unit and small batch production } \\
\text { Continuous process production }\end{array}$ \\
\hline
\end{tabular}

Table 4.8: The relationship between the environmental dimensions and manufacturing technology

So, when the firms in the entire sample are considered, interpretable differences in how their manufacturing technology relates to the environmental dimensions indeed emerge. To obtain a more detailed picture, the companies in the chemical and food \& 
drink industries are examined separately for the broad technology categories as well as for the more refined classification that incorporates the advanced manufacturing technologies. Kruskal-Wallis tests on the environmental dimensions by the broad manufacturing technology types indicate that within the chemical industry significant differences exist on neither dimension 1 nor dimension 2 . However, the relationships as summarized in Table 4.8 are, although not significant, also detected in the chemical industry. In the food \& drink industry this holds true as well. On dimension 1 the food \& drink results are significant at $p=0.0376$.

With respect to the relationship between the refined categories of manufacturing (five in the chemical industry and seven in the food \& drink industry) and the environmental dimensions, the following is hypothesized:

1. On dimension 1, the continuum between drive to cost control and drive to innovate, the advanced manufacturing technologies are expected to rank in the following order corresponding to the sliding scale of the dimension: automated planning in continuous process production, automated design in continuous process production and automated continuous process production receive similar rankings followed by flexible continuous process production, modified large batch and mass production, automated large batch and mass production, flexible large batch and mass production and, finally, innovative large batch and mass production. The ranking is "again, based on the implicit assumption that as the level of flexibility and integration in manufacturing techinology increases, the ability to develop and produce (new) products is facilitated (Parthasarthy \& Sethi, 1993). This also implies that a sole emphasis on development of the process decreases with the level of flexibility (Zahra \& Covin, 1993).

2. On dimension 2, the continuum between drive to sophisticated marketing and drive to minimize the marketing effort, the advanced manufacturing technologies are expected to rank in the following order corresponding to the sliding scale of the dimension: innovative large batch and mass production, flexible large batch and mass production, automated large batch and mass production, modified large batch and mass production, flexible continuous process production and, finally, the three categories of automated planning in continuous process production, automated design in continuous process production and automated continuous process production that are again expected to rank similarly. This ranking is, again, based on the assumed rellationship with the ability to emphasize development and production of (new) products (Zahra \& Covin, 1993) and on the assumption that the flexibility benefits flowing from the implementation of advanced manufacturing technologies can be a marketing tool to better meet customers' needs (Meredith \& McTavish, 1992).

Kruskal-Wallis tests in the chemical and food \& drink industries were performed to test the hypotheses. In the chemical industry no significant differences between the 
manufacturing categories with respect to dimension 1 emerged. The proposed ranking seems to be present, however, although the position of innovative large batch and mass production is rather odd. The most innovative manufacturing technology was expected to operate in an environment with a strong drive to innovate and not in an intermediate position. In the food \& drink industry also no significant differences appeared with respect to dimension 1. The proposed ranking holds for most of the categories, except for innovative large batch and mass production and modified large batch and mass production. The modified large batch and mass production firms apparently operate in an environment with a drive to cost control, which in itself is appropriate. Relative to the continuous process categories, however, it was expected to receive a higher mean rank. This also holds true for the innovative large batch and mass production firms that, although they operate in an environment with a drive to innovate, were expected to rank above automated and flexible large batch and mass production. On dimension 2 also no significant differences between the manufacturing categories appear. The proposed ranking holds in chemicals, however, although the ranking of modified large batch and mass production of flexible continuous process production is reversed. In the food \& drink industry the proposed ranking in general also holds, except for the categories of modified large batch and mass production and flexible continuous process production that were both expected to rank higher on sophisticated marketing. Explanations concerning the manufacturing technology that fail to rank as expected, are provided in Section 4.5 when the relationship with strategy and the competitive environment is examined. These results are summarized in Table 4.9 .

\begin{tabular}{|c|c|c|}
\hline Envirommantal dimpunstorts & Chempicals (mean romk) & Foad \& Drimks fmean rank \\
\hline Drive to chost contrall & Automated continuous process (2) & Automated design in corytifuous process $11 !$ \\
\hline 1 & & Modified large batch and mats 121 \\
\hline ! & Flexible continuons promess $(4)$ & Automated planning in comtiruous process 13 \\
\hline 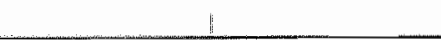 & 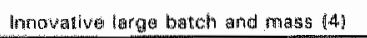 & 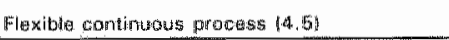 \\
\hline d" & & Irnowative large batch and mass $(7.5)$ \\
\hline 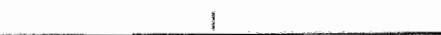 & Modiliad larga batch and inass 154 & ALtomaled Haxge batch and mass (8) \\
\hline Dravis to inflowato & Faxitola largo batch and nass 171 & Floxiblle large watch and mass (10) \\
\hline Drive tho sophigticated marketing & 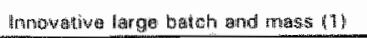 & limovative large batch and mistas (1.5) \\
\hline i & Flexithe lange batroh and mass (3i) & Frlexible large batcth and mass (4.5) \\
\hline 1 & & Auttomated planing in cominumuts pracess i5j \\
\hline 1 & Flextibles continuous process (4) & Automated large batch and mags 171 \\
\hline 1 & & Atutomated design in continuous procests (7) \\
\hline 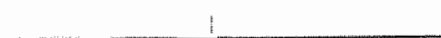 & Modifed large batch and mas: (15): & Modified large bathen and mass 184 \\
\hline Drive to rinimize ryarkestirkg effort & Automated continuous processi $\{5,5\}$ & Frexible contimuth procesis 1101 \\
\hline
\end{tabular}

Table 4.9: Ranking of refined manufacturing technologies on the environmental dimensions 


\subsection{The technological setting related to strategies pursued in their respective competitive environments}

Although no statistically significant relationship between the technological setting and the environmental dimensions is found in the chemical and food \& drink industries, a more or less consistent pattern was indeed observed. The question therefore arises whether the pattern observed here is consistent with the relationship between the environment and strategy as described in Chapter 3. In other words: do the technological setting and the strategies pursued reinforce each other to obtain competitive advantage?

Since the different manufacturing technologies each have different competencies in processing volume and variety, the companies should pursue strategies that utilize the specific capabilities of the chosen manufacturing technology (Parthasarthy \& Sethi, 1992). As Chapter 3 describes, the generic strategies pursued by the companies in our sample are classified into eight categories: defenders, analyzers, prospectors (Miles and Snow, 1978), cost leadership, differentiation, cost focus, differentiation focus (Porter, 1980) and a combination strategy of cost leadership, differentiation and focus. In the chemical and food $\&$ drink industries, all of these types - except the prospectors - are present. Each strategy type and its hypothesized relationship with the technological setting will be subsequently discussed.

1. Cost leadership

Cost leadership strategies have as their primary objective to minimize cost in all areas. This does not mean, however, that thereby development of the production process is rendered unimportant. Quite to the contrary: since process development can substantially contribute to the experience effect, it thus enthances economies of scale (Dussauge, Hart \& Ramanantsoa, 1992). Product development in this strategy is aimed at reducing product cost rather than at seeking completely new products (Porter, 1983). This implies long production runs of a narrow model range with little customization and infrequent design changes (Meredith \& McTavish, 1992). It is therefore expected that this strategy is mainly associated with modified and automated large batch and mass production or automated continuous process production.

\section{Differentiation}

In a differentiation strategy the competitive advantage is based on specific unique product characteristics that are valued by the buyers. So, product development will be directed towards the development of these unique characteristics. Development of the production process will be geared towards such issues as faster response time to orders and greater quality control (Meredith \& McTavish, 1992; and Porter, 1983). The differentiation strategy is therefore more likely to be associated with the flexible or innovative 
manufacturing technologies.

3. Cost focus

The same relationship with the technological setting is expected as for cost leadership. The only difference between the two strategies is that a cost focus strategy directs its efforts towards a narrowly defined target market. Depending on the segment chosen, the emphasis on development of the production process or products may even be less since only the needs of that segment need to be satisfied.

\section{Differentiation focus}

For this strategy the same relationship with the technological setting holds as for the differentiation strategy. As in the case of a cast focus strategy, the emphasis on development may even be more modest since only the needs of the chosen specific segment need to be considered.

5. Combination of cost leadership, differentiation and focus

For the firms pursuing a combination strategy of cost leadership, differentiation and focus a distinction has to be made between the firms that base the differentiation part of their strategy purely on brand name or image - so as to create a perceived added value - and the firms that base their differentiation on real added value, like enhanced quality. As was explained in Chapter 3 . especially in consumer industries such as food \& drinks a perceived differentiation can be sustained. For the relation to manufacturing technology. it makes a difference which type of combination strategy is pursued. In the case of the cireation of a perceived value, the manufacturing technology will have more features of a cost leadership (or cost focus) strategy, since development of products is not necessarily directed towards developing new products (but to, for example, modifying existing ones). In the case of the creation of real added value, the manufacturing technology will resemble that of the differentiation (focus) firm, although, due to the combination with cost leadership, flexible manufacturing technologies are more likely than innovative manufacturing technologies.

6. Defender's

One of the main characteristics of the defender strategy is that the majority of resources is invested in how to produce and distribute goods as efficiently as possible. So, cost-efficient technology is crucial. Product development outside the present domain is unlikely, and development of the process is directed towards making existing operations as efficient as possible, thereby trying to create a buffer for change (Miles \& Snow, 1978). The modified and automated manufacturing technologies are therefore most likely to be associated with the defender strategy.

7. Analvzers

The analyzer is characterized by a dual technological core. In its stable domain 
it needs to achieve standardization and cost efficiency, in its changing domain it needs to be very flexible in respond to changes (Miles \& Snow, 1978). Of all the strategies discussed, the analyzer would benefit most from the utilization of flexible manufacturing technology that can be adapted to both domains. The fllexible and innovative manufacturing technologies are therefore most likely to be associated with analyzer strategies.

These strategy-manufacturing technology relationships are summarized in Table 4.10.

\begin{tabular}{|l|l|l|}
\hline Sirategy & $\begin{array}{l}\text { Proposed relationship with manufacturing } \\
\text { technology }\end{array}$ \\
\hline 1. & Cost leadership and cost focus & Modified or automated manufacturing technology \\
\hline 2. & Differentiation and differentiation focus & Flexible or innovative manufacturing technology \\
\hline 3. & $\begin{array}{l}\text { Combination strategy of perceived value } \\
\text { differentiation, cost leadership and focus }\end{array}$ & Modified or automated manufacturing technology \\
\hline 4. Combination strategy of real value & Flexible or innovative manufacturing technology \\
\hline 5. & Defender & Modified or automated manufacturing technology \\
\hline 6. & Analyzer & Flexible or innovative manufacturing technology \\
\hline
\end{tabular}

Table 4.10: Proposed strategy-manufacturing technology relationships

Because of the small number of observations in our sample, these proposed relationships cannot be statistically tested with a Chi-square analysis. What can be done, however, is to cluster the manufacturing technologies employed on the basis of the environmental dimensions. The resulting clusters are then identical to the strategy clusters presented in Chapter 3, only labeled differently. When the two plots of the cluster analysis are then compared, the consistency and logic of the manufacturing technology-strategy types can be analyzed in their respective environmental contexts. The advantage of such an approach is that the technological setting can be simultaneously compared with the generic strategy and the environmental dimensions. The cluster procedure is presented in Appendix D. The three clusters in the food $\&$ drink industry and the four chemical clusters are, labeled with generic strategies and manufacturing technology, presented in Figure 4.2. The results for each industry will be discussed below. The numbers of the companies correspond to a short description provided in Appendix A.

\section{Food \& drinks}

Where the content of each food \& drink cluster in Chapter 3 seemed to be a rather diverse collection of strategies, the picture concerning the manufacturing technologies employed suggests more consistency. Because if one moves from left to right on 
dimension 1, so from the drive to cost control to the drive to innovate, the modified and automated manufacturing technologies are located on the left and the flexible and innovative manufacturing technologies on the right of the dimension 1 , as was predicted.

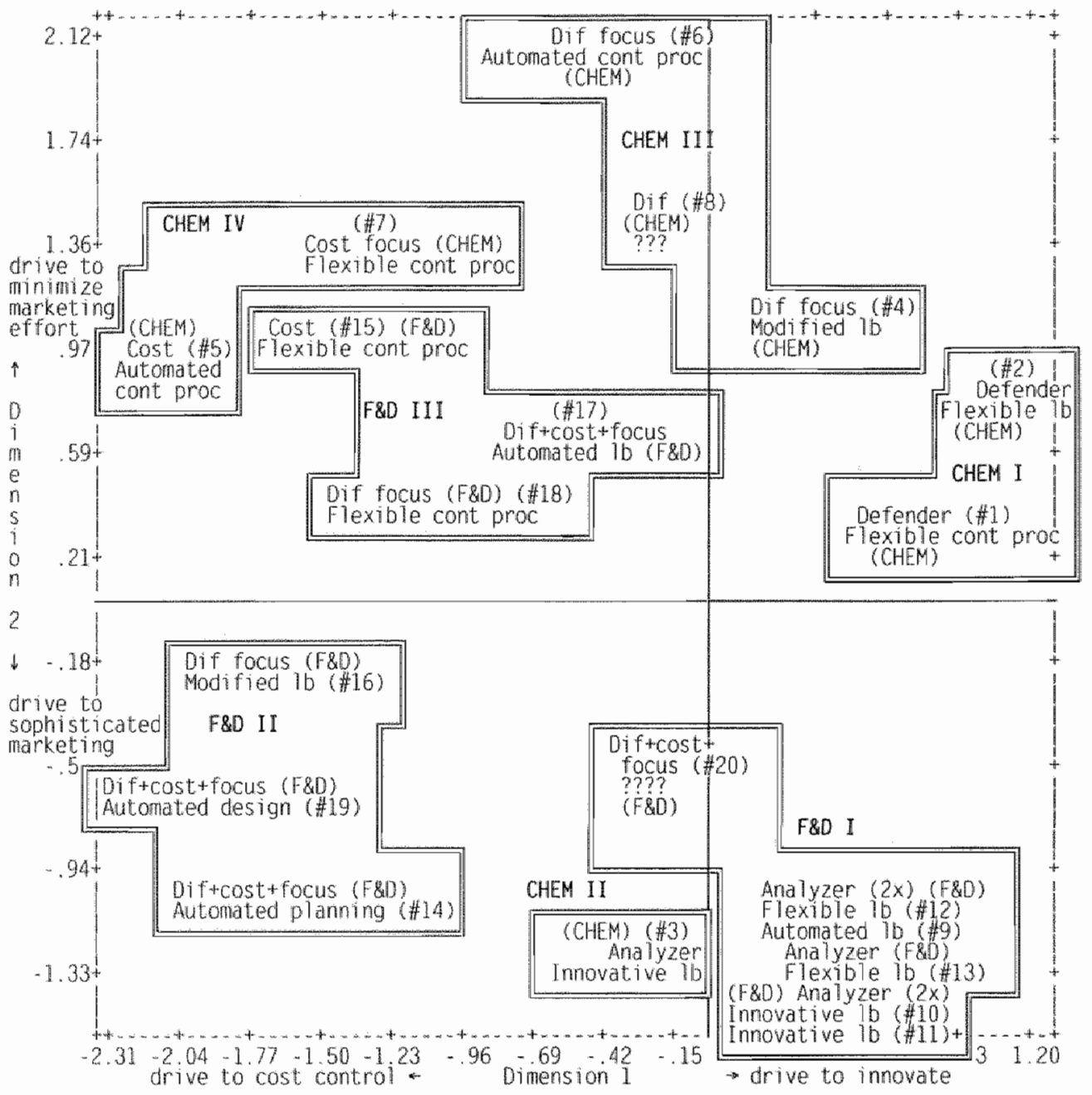
CHEM =
Chemicals
$F \& D=$
Food \& drinks
Dif $=$
Differentiation
Dif focus $=$
Differentiation focus
Dif $+\cos t+$ focus $=$
Combination of differentiation, cost leadership and focus
$\cos t=$
Cost leadership
cont proc $=$
Continuous process production
$b=$
Large batch and mass production

Figure 4.2: Chemical and food \& drink clusters labeled with technology-strategy pair 
Furthermore, dimension 1 distinguishes between continuous process production and large batch and mass production. The importance of economies of scale and thus cost control in continuous process production firms is underlined by their position on the left of this dimension. The large batch and mass production firms, with the exception of firm 16 located in cluster 11 and firm 17 in cluster 111 , are located more on the right side of dimension 1 . The proposition that a move of large batch and mass production firms towards a drive to innovate is made possible by the adoption of advanced manufacturing technologies, seems to contain some truth in this sample. All the large batch and mass production firms, with three exceptions, employ flexible or innovative manufacturing technologies.

Which manufacturing technology-strategy combinations are located in each cluster is summarized in Table 4.11 .

\begin{tabular}{|c|c|}
\hline Cluster & Manufacturing technology-strategy combinations \\
\hline 1 & 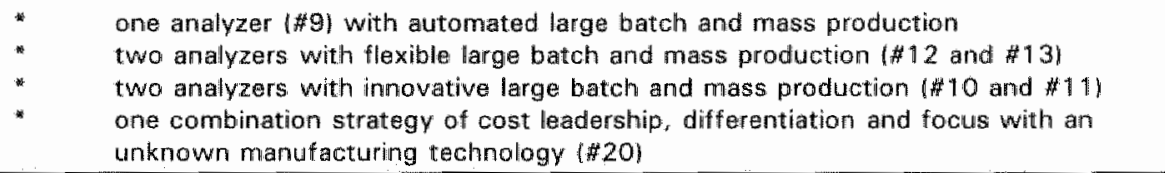 \\
\hline\|\| & $\begin{array}{l}\text { one combination strategy of cost leadership, diferentiation and focus with } \\
\text { automated planning in continuous process production (H1 } 4 \text { ) } \\
\text { *ne combination strategy of cost leadership, differentiation and focus with } \\
\text { automated design in continuous process production (H19) } \\
\text { one differentiation focus strategy with modified large batch and mass production } \\
\text { (\#16) }\end{array}$ \\
\hline 111 & $\begin{array}{l}\text { * one cost leadiship strategy with flexible continuous process production (\#15) } \\
\text { * } \quad \text { differentiation focus strategy with flexible continuous process production (t) } 18 \text { ) } \\
\text { *ne combination strategy of cost leadership, differentiation and focus with } \\
\text { automated large batch and mass production (\#17) }\end{array}$ \\
\hline
\end{tabular}

Table 4.11: Three food \& drink clusters labeled by their manufacturing technologystrategy combinations

The firms in food \& drink cluster I present a very consistent group, except for firm 20 pursuing the combination strategy and company 9 with automated large batch and mass production. Unfortunately however, no data could be obtained concerning the manufacturing technology of company 20 , so no further investigation is possible at this point as to why this firm is situated in this cluster. Company 9 with automated large batch and mass production is lagging behind its competitors concerning the level of flexibility and integration in production. Whether this results in inferior performance is discussed in Chapter 7 . For the other four firms, an analyzer strategy is associated with flexible or innovative large batch and mass production, as was expected. This also confirms the notion generated in Chapter 3 that these analyzer firms form a strategic group within the food \& drink industry, since not only their strategies but also their manufacturing policies are similar. Chapter 3 also raised the question, which 
could not be answered at that point, of why no prospectors were found in this cluster. as theory would predict. Based on the current knowledge of the manufacturing technology employed by the companies, an explanation can be provided. The prospector strategy is characterized by a very dynamic profile in which multiple technologies are develloped for a diverse product portfolio. In the extreme case no commitment to any specific technology is made for fear of missing opportunities (Miles \& Snow, 1978). This is why the prospector was expected in an environment with a drive to innovate and a drive to sophisticated marketing. With the development of the advanced manufacturing technologies, however, taking the risk of a prospector strategy becomes unnecessary, as the advanced manufacturing technologies (i) increase the flexibility of the design, production and control function substantially and (ii) allow the firm to simultaneously engage in existing, known, operations. So, the objectives that traditionally a prospector would be best equipped to satisfy, can now be met with a considerably safer analyzer strategy.

The two firms in food \& drink cluster II that pursue a combination strategy of cost leadership, differentiation and focus both emplloy the least advanced modes of continuous process production: automated planning (company 14) and automated design (company 19). This is also consistent with what is expected. These two firms, operating in an environment with a drive to cost control and a drive to sophisticated marketing, combine cost leadership with a marketing differentiation strategy with which they try to create perceived rather than real added value. The modest adoption of advanced manufacturing technologies is geared towards lowering costs rather than developing new products. The other firm present in the sample - company 16 remains the odd one out. As was discussed in Chapter 3, the pursuit of a differentiation focus strategy is almost impossible in this type of environment, and the manufacturing technology employed - modified large batch and mass production inhibits the pursuit of this strategy even more. Because the use of more 'traditional' large batch and mass production is associated with a technical emphasis on process efficiency (Nemetz \& Fry, 1988), this firm's manufacturing technology as such does indeed fit with the environment. This would lead to the conclusion that in this case the strategy actually implemented differs from the strategy formally stated. If this is not the case, the firm should suffer from inferior performance as then a mismatch between competitive environment, strategy and manufacturing technology exists. Which situation applies here is discussed in Chapter 7 where the relationship to company performance will be examined.

Finally, three firms are located in food \& drink cluster III. Although the relationship in all three firms between the manufacturing technology and the strategy pursued appears to be as expected on theoretical grounds, the position of the differentiation focus firm - company 18 - and the company pursuing a combination strategy - company 17 - remains odd, as the strategy-technology pair implemented is not consistent with environmental conditions. The only possible explanation at this 
poirt coulld be that since their strategy and manufacturing technology reinforce each other, they are moving in the direction of food \& drink cluster I. This potential shift, of course, also implies that although these two firms may together form a strategic group, the cost leadership firm - company 15 - is definitely not a group member. Especially since theoretically the manufacturing technology employed is too "advanced" for the generic strategy pursued and the competitive enviromment.

\section{Chemicals}

When inspecting the firms in the four chemical clusters, the opposite from what was found in the food \& drink clusters can be observed. While each of the clusters with respect to their strategy seemed to form a coherent whole, there is fewer consistency in the firms" manufacturing technologies. What is consistent, though, with the trend abserved in the food $\&$ drink industry is that the continuous process production firms tend to be located on the left side of dimension 1, with one exception in chemical cluster 1 , whereas the large batch and mass production firm are located more the drive to innovate end of the scale. The explanation for this phenomenon is that the large batch and mass production firms are able to operate in this environment because of the implementation of advanced manufacturing technology.

Which manufacturing technology-strategy combinations are present in each of the chemical clusters is presented in Table 4. 12.

\begin{tabular}{|c|c|}
\hline Cluster & Manufacturing technolagy-strategy combinations \\
\hline 1 & $\begin{array}{l}\text { *ne defender with flexible large batch and mass production }(H 2) \\
\text { * } \quad \text { one defender with flexible continuaus process production }(\# 1)\end{array}$ \\
\hline$\| 1$ & one analyzer with innovative large batch and mass production (H) \\
\hline$m$ & $\begin{array}{l}\text { *ne differentiation focus strategy with modified large batch and mass production } \\
\text { * } 4 \text { ) } \\
\text { one differentiation focus strategy with automated continuous process production } \\
\text { (H5) } \\
\text { One differentiation strategy with unknown manufacturing technology (\#B) }\end{array}$ \\
\hline IV & $\begin{array}{l}\text { *ne cast leactership strategy with automated continuous process production (f } 5 \text { ) } \\
\text { *ne cost focus strategy with flexible continuous process production }(7) \text { ) }\end{array}$ \\
\hline
\end{tabular}

Table 4.12: Four chemicalclusters labeled by their manufacturing technology-straregy combinations

The two companies in cluster I pursuing a defender strategy form a rather odd pair, since their manufacturing technologies do in both cases not match their strategy. The manufacturing technology, however, fits well with the environmental conditions of drive to innovate and drive to minimize the marketing effort. So, it seems that the suggestion in Chapter 3 of a potential reactor strategy gains some merit: although the company has adapted the manufacturing technology to the perceived competitive environment, its generic strategy has lagged behind, in which case the company 
cannot make full use of its new manufacturing technology. Whether this company is really a reactor or 'stuck in the middle' is examined in Chapter 7. Almost the same reasoning applies to defender company 1. Although also flexible continuous process production is consistent with environmental conditions, a mismatch exists with regard to strategy.

The one company in chemical cluster II following an analyzer strategy - company 3 - raised questions in Chapter 3 as to its location in an environment with a modest drive to cost control and a strong drive to sophisticated marketing. The fit between the environment, strategy and manufacturing technology is, however, consistent. The suggestion that this company operates in one of the downstream chemical sectors where a strong identification with final customers' needs - beyond the technical specifications of the product - is necessary, seems to be confirmed.

Two differentiation focus firms in cluster III - companies 4 and 6 - for which data on the manufacturing technology could be obtained, employ modified large batch and mass production (company 4 ) and automated continuous process production (company 6). Modified or automated production were not expected to be associated with a differentiation focus strategy. A potential misfit therefore exists. The differentiation focus firm 4 that employs modified large batch and mass production operates in an environment with a modest drive to innovate and a drive to minimize the marketing effort. So for this firm the environment-technology combination is also inconsistent. The other differentiation focus company operates in an environment with a modest drive to cost control and a strong drive to minimize marketing efforts, as would be expected with automated continuous process production. Considering their strategies and manufacturing technologies, these companies could belong to the same strategic group.

Finally, in cluster IV two firms pursuing a cost leadership and cost focus strategy can be found. The company following a cost leadership strategy - company 5 - employs automated continuous process production, as was predicted. Company 7. with a cost focus strategy, employs flexible continuous process production that neither matches the environmental conditions nor the strategy pursued. The question arises of why this firm would have invested in advanced manufacturing technologies when this does not match its environmental conditions nor its strategy. The only explanation could be that the investments in advanced manufacturing technology improve efficiency to such an extent that substantial production cost savings are made feasible (thereby reinforcing the pursuit of a cost focus strategy). 


\subsection{Conclusion}

The analysis in this chapter can be divided into two main parts.

The first part addresses the question whether the implementation of advanced manufacturing technologies alters the traditional production categories as developed by Woodward (1965). The analysis indicates that a difference in perception of developments in the production environment indeed exists between those firms that did and those that did not adopt advanced manufacturing technologies. A refinement of Woodward's 1965) typology is developed for the two production types present in the chemical and food $\&$ drink sample based on the degree of flexibility and integration expected to be abtained by implementation of advanced manufacturing technologies. In large batch and mass production four categories are distinguished that represent a gliding scale from little to much flexibility and integration: modified large batch and mass production, automated large batch and mass production, flexible large batch and mass production and, finally, innovative large batch and mass production. In continuous process production only two opposite poles on this continuum are observed. Little flexibility and integration is present in those companies that automated only one aspect which results in the categories: automated planning in continuous process production, automated design in continuous process production and automated continuous process production. On the opposite end of the continuum resides flexible continuous process production where a relatively high level of flexibility and integration is assumed. It should be noted, however, that due to the nature of continuous process production, the 'base' level of integration between the stages of production, is already much higher than in large batch and mass production.

The second part of this chapter relates the refined production categories in the chemical and food \& drink industry to the competitive environment and generic strategles. The majority of companies in the food \& drink as well as in the chemical industry indeed possess consistent technology-strategy combinations that match environmental conditions. Four exceptions are located in the food \& drink industry and four in the chemical industry. These either suffer from inconsistent technology-strategy pairs or from misalignment with the environment. Whether a lack of fit result in inferior performance compared to competition is discussed in Chapter 7.

There are, however, two main limitations of the analysis in this chapter that need to be explicitly mentioned. The first limitation concerns the construction of the broad "traditional" production categories in Section 4.2. In order to make the Dutch and British categorizations comparable, some of the variety in the data was lost. Especially relevant to the implementation of advanced manufacturing technologies might have been the difference between mass production with frequent product changes and mass production with a standard product or the difference between companies with combinations of production types and companies with single type of production system. This problem of international research has also been addressed in 
Chapter 2.

The second limitation concerns the assessment of the real impact the adoption of advanced manufacturing technologies has on operations in production. It is assumed that the production function becomes more flexible and integrated as more advanced manufacturing technologies are implemented. Implementation of these advanced technologies does, however, not automatically lead to such benefits since this effect is mitigated by three factors (Schroeder, 1990). First, after the implementation of advanced manufacturing technologies continuous development and improvement takes place as operating experience with these new systems increases. The degree of development and improvement - and thus the ability to benefit from the operating experience - may differ over firms. Second, and related to the first factor, not all firms adopt the advanced manufacturing technologies simultaneously, causing differences in the time they have to accumulate experience. Finally, the success of implementation also depends on developments in related areas within the firm that should complement - or at least not impede - the derivation of flexibility and integration benefits. In order to gain some insight into these three factors at least the time of implementation of advanced manufacturing technologies in the companies should be known. Furthermore, performance measures should be developed that enable the determination of different levels of flexibility and integration which are actually obtained. 


\title{
CHAPTER 5
}

\author{
HUMAN RESOURCE MANAGEMENT
}

\section{IN RELATION TO THE COMPETITIVE ENVIRONMENT AND GENERIC STRATEGIES}

In this chapter specific personnel policies are examined in the light of human resource management (HRM). Human resource management carries the promise that if people are regarded and managed as strategic resources, it can help the firm obtain a competitive advantage and superior performance (Porter, 1985). This implies that the management of personnel should be in line with the generic strategy pursued, since the objectives and requirements of each of the generic strategies differ (Schuler, 1992; and Arthur, 1994). There is little empirical evidence, however, that human resource management indeed fulfills its promise (Lengnick-Hall \& Lengnick-Hall, 1988). Whether the companies in our sample integrated their personnel policies with their generic strategy, is examined in this chapter.

Section 5.1 discusses the concept of human resource management and provides a definition. Section 5.2 describes aspects of the national culture, business system and industrial relations in the Netherlands and Great Britain, since personnel policies and practices are strongly rooted in the respective national institutional contexts. In Section 5.3 the features of the national business systems are related to the components of HRM. Support is provided for the hypothesis that a societal effect has an impact on the implementation of HRM components. Section 5.4 then examines the degree of strategic integration of the personnel function in a qualitative manner, while in Section 5.5 the relationship between personnel policies and generic strategies pursued is discussed. A typollogy of HRM strategies is proposed based on the degree of strategic integration and decentralization of personnel policies. Finally, in Section 5.6, the fit between personnel policies, generic strategies and the competitive environment is explored. Support is provided for the hypothesis that coherent environment-strategy-HRM policy combinations exist: in effect, in the majority of the cases the HRM policy supports the generic strategy chasen. Furthermore, like in all previous chapters, special attention is devoted to the chemical and food \& drink industry. Figure 5.1. presents a summary of the relationships studied in this chapter. 


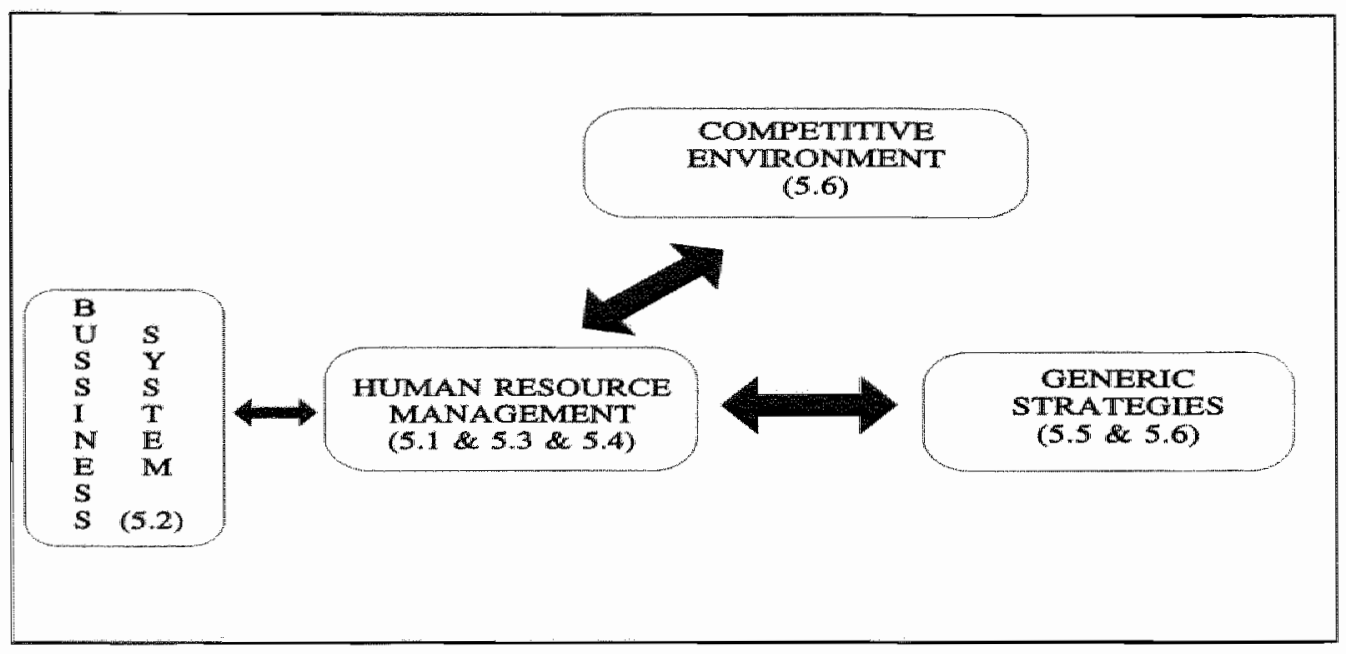

Figure 5. 1: The relationship between human resource management, the competitive environment and generic strategies

\section{1 Human Resource Management (HRM) defined}

Due to deregulation, decentralization and internationalization of labor relations as well as changes in the labor market, technological development and increasing competition, the function of personnel management in organizations is changing (Schuler $1987 \mathrm{~b}$; Kluytmans, 1989; and Samson \& Brongers, 1993). Decentralization and deregulation lead to increasing autonomy for the employers to set labor policies for their companies. Furthermore, technological development and increasing competition change the principles on which the workforce was previously controlled.

To deal with the aforementioned changes and inspired by distinguished management scholars, human resource management (HRM) is often sought of as part of the solution. However, to determine whether Dutch and British companies actually move from "traditional" personnel management to a "new' HRM approach, an understanding is needed as to how HRM can actually be defined. The HRM concept has received considerable sceptism and has aroused plenty of confusion as to what it actually embraces. One of the leading Dutch text books describes a trend of innovation and commercialization in which development of personnel becomes more important than simple control of personnel (Kluytmans, 1990). Kluytmans (1990: 38) adds: "When one desires to attach the term human resource management to this trend, one may. This however does not mean that thereby also the promising premises of this school are realized" (our translation). Schuler (1987b) defines personnel and human resource management as the management of the workforce as vital human resources that are critical to the achievement of organizations ${ }^{\prime}$ goals. HRM policies 
therefore need to be directed at the effective and fair use of the human resources to the benefit of the individual, organization and society. Blackburn \& Rosen (1993) provide examples of award winning companies that achieve their high quality goals by HRM policies that are internally consistent and completely geared toward supporting the total quality management perspective. Storey (1992) makes an attempt to position the different meanings associated with HRM on a matrix which distinguishes between HRM as a distinctively new approach to labor management versus HRM as just another term for personnel management on the one hand and hard - with an emphasis on personnel as a resource - versus soft versions of HRM - with an emphasis on personnel as humans - on the other. So, a clear definition of HRM is not readily available. HRM scholars agree, however, upon the observation that these trends - or set of changes - are based on the following three principles (Kluytmans, 1989; Fisscher, Middel \& Vinke, 1992; Sorge, 1992; and Storey, 1992):

1. People are an important resource in the achievement of the organization"s goals. HRM should create the conditions which permit to utilize the human capital resources as fully as possible.

2. The management of human resources should be an integral part of the strategy process, such that the strategic goals of the organization and the human resource policies reinforce reciprocally and form a coherent whole. HRM can be a determining factor in the development of a competitive company, instead of just a passive absorber of the implications of the decisions made in other functional areas. To facilitate this, the personnel function has to move away from central staff to decentralized units and line management positions.

3. The different aspects of HRM - such as recruitment and selection, performance appraisal and compensation, and training and development- should be integrated as efficiently as possible. Furthermore, the HRM elements should allow for flexibility and adaptability in line with the strategy pursued.

The concept of fit, as discussed in Chapter 2 , is clearly reflected in the aforementioned three principles. The first two principles address the external fit of HRM, while the third principle indicates the importance of an internal fit between the diverse HRM functions (Baird \& Meshoulam, 1988; and Milliman, Von Glinow \& Nathan, 1991). Fit in this case, however, should not be viewed as a completely static phenomenon precluding flexibility, as for example Lengnick-Hall \& Lengnick-Hall (1988) would argue. The definition points more in the direction of a perspective where fit and flexibility are complementary and the organization thus continually adapts to achieve a fit with the internal and external environment (Miles \& Snow, 1984).

The number of propositions on how external and/or internal fit could be achieved reaches infinity. Examples focus on the relationship between HRM and the stage within the organization life cycle (Baird \& Meshoulam, 1988; Lenginick-Hall \& LengnickHall, 1988; and Milliman, Von Glinow \& Nathan, 19911, on the person-organization fit (Bowen, Ledford \& Nathan, 1991; and Schuler, 1992), on the relationship between 
diversification and compensation strategy (Gomez-Meija, 1992), on the effect of human resource systems on manufacturing performance (Arthur, 1994) and on the relationship between generic strategies and HRM (Miles \& Snow, 1984; and Schuler, 1987a). Characteristic for these studies, except the latter two, is that they either address one very specific aspect of HRM and relate this to environmental or organizational characteristics or treat HRM as a not further specified set of practices for which one strategy - a HRM strategy - is formulated. In this chapter an attempt is made to combine these two approaches. First, the different components of HRM recruitment and selection, performance appraisal and compensation, and training and dewelopment - are related to features of the Dutch and British business system to gain an understanding of the impact of a societal effect (Sorge, 1991) on the adoption of HRM. Then, the relationship between the type of HRM strategy, the generic strategy pursued and the competitive environment is examined. So, to set the scene in which the management of personnel or human resources in the Netherlands and Great Britain takes place, aspects of the Dutch and British national culture, business system and industrial relations are introduced in Section 5.2.

\subsection{National culture, the business system and industrial relations}

The notion that the management of employees within organizations is constrained by the characteristics of the national culture, business system and industrial relations is widely recognized (Guest, 1990 \& 1987; Sorge, 1991 \& 1992; and Begin, 1992 ). Since the concept of human resource management originated in the United States, it is built on assumptions that are rooted in the US national culture, business system and industrial relations. The centrall assumption here is that of organizational independence and autonomy. Generally, in Europe this autonomy is constrained by culture and legislation, larger state involvement, trade unions et cetera (Brewster, 1993). A brief outline of the Dutch and British cultural and institutional context will therefore provide an overview of the opportunities and limits for both HRM professionals and researchers.

A business system of a country can be defined as the institutionally embedded practices and value orientations which characterize the internal organization of firms and their relation with the external environment (Whitley, 1992). In other words, dominant social institutions in a country, such as the state, influence the functioning of firms and markets. Furthermore, the institutionally embedded value orientations are rooted in the national culture. By way of illustration characteristics of the Dutch and British culture and six institutional factors that govern HRM within Dutch and British companies are discussed below. 


\subsubsection{Characteristics of the Dutch and British national culture}

Hofstede (1991) defines the national culture as "the collective programming of the mind which distinguishes the members of one group or category of people from another" (Hofstede, 1991: 5). This definition implies that culture is learned and derived from the social environment. Since the social environment within a country is fairly homogeneous - due to, for example, a national education system, national laws and a national political system - it can be assumed that people in different countries are, by and large, programmed differently. To measure these differences Hofstede developed a questionnaire that captures four dimensions of national culture: the level of power distance, individualism versus collectivism, the level of uncertainty avoidance and masculinity versus femininity. Each of these dimensions will be briefly discussed below.

The first dimension, power distance, refers to the extent to which it is expected and accepted that power is unequally distributed among people. An example of how this is reflected in the functioning of organizations is the degree to which authority stemming from position in a hierarchy is accepted without question. When the power distance is small, a superior is more likely to discuss a task before assigning it to a subordinate, while in a large power distance country it is more accepted that a superior simply arders that a specific task is to be performed.

Individualism versus collectivism, the second dimension, describes how relationships between people are viewed. In individualistic societies, on the one hand, people are relatively independent: hence, ' $I$ ' and immediate family provide the frame of reference for most decisions. In collectivist societies, on the other hand, people are integrated into cohesive groups that protect them in exchange for unquestioning loyalty: so, "we' is the primary reference point that is considered. An example of what this means for organizations is the design of the reward system. In a society that underscores the individual, rewards can be based on personal achievement. In a country where the collectivism prevails rewards are more likely to be related to the accomplishments of the group, occasionally to such an extent that individual performance appraisal is frowned upon.

The third dimension is uncertainty avoidance or the way in which people, on average, deal with uncertainty. In a country with high uncertainty avoidance, unknown situations are perceived as threatening. People accustomed to such a cultural setting feel most comfortable in work situations that are well-structured in the form of detailed job descriptions. People in weak uncertainty avoidance countries, in contrast, are more lenient towards situations that deviate from the standard. Therefore, they function best in an environment with few rules guiding behavior.

Finally, the fourth dimension - masculinity versus femininity - describes the degree to which the masculine and feminine gender roles are clearly distinct in a country. In masculine societies, masculine values - such as assertiveness, toughness 
and competition - dominate. In feminine societies values like quality of life, modesty and concern for relationship, play a larger role. The degree of masculinity or femininity of a country is reflected in, for example, the way labor relations are organized. In a masculine country conflicts between labor unions and company management tend to be resolved by a good fight, while in feminine countries the tendency is towards negotiation (Hofstede, 1991: 92). Another example is, again, the structure of the reward system of companies. In a masculine culture rewards are distributed on the basis of equity according to performance, but in a feminine culture on the basis of equality according to needs.

The score the Netherlands and Great Britain obtained on these four dimensions and the ranking within the 53 countries and regions investigated by Hofstede (1991) are presented in Table 5.1. Since the vast majority of the HRM literature originated in the USA the scores for this country are included as benchmarks.

\begin{tabular}{|c|c|c|c|c|c|c|}
\hline \multirow[t]{2}{*}{ Dimensions of curture } & \multicolumn{2}{|l|}{$U S A$} & \multicolumn{2}{|c|}{ Great Britain } & \multicolumn{2}{|c|}{ The Netherlands } \\
\hline & Score & Rank & Score & Rank & Score & Rank \\
\hline $\begin{array}{l}\text { Power distance } \text { (rank } 1=\text { large; rank } \\
53=\text { small }\end{array}$ & 40 & 38 & 35 & $42 / 44$ & 38 & 40 \\
\hline $\begin{array}{l}\text { Individualism versus collectivism (rank } 1= \\
\text { individualist; } \operatorname{rank} 53=\text { collectivist) }\end{array}$ & 91 & 1 & 89 & 3 & 80 & $4 / 5$ \\
\hline $\begin{array}{l}\text { Masculinity versus femininity (rank } \\
1=\text { masculine; rank } 53=\text { feminine) }\end{array}$ & 62 & 15 & 66 & $9 / 10$ & 14 & 51 \\
\hline $\begin{array}{l}\text { Uncertainty avoidance (rank } 1 \text { = high; rank } \\
53=\text { low }\end{array}$ & 46 & 43 & 35 & $47 / 48$ & 53 & 35 \\
\hline
\end{tabular}

\section{Table 5.1: National cultures in the USA, Great Britain and the Netherlands}

As can be revealed from Table 5.1, the ranking of the Netherlands, the USA and Great Britain is rather similar on three of the dimensions. All three countries are characterized by a relatively small power distance, are individualistic and possess a relatively low uncertainty avoidance. The only dimension on which the Netherlands scores substantially different from the USA and Great Britain - the latter two scoring similar on this dimension - is masculinity versus femininity. Whereas the USA and Great Britain are fairly masculine societies, the Netherlands is one of the most feminine countries in Hofstede's sample. These characteristics of Dutch and British culture are reflected in how the respective business systems and industrial relations are organized. 


\subsubsection{The Dutch business system}

The six institutional factors that govern HRM concern the structure of decision power within Dutch companies, Dutch industrial relations, the Dutch labor market, the economic demography of the Netherlands, the Dutch education system and future developments that possibly alter any of the aforementioned five factors (King, 1990; Sarge, 1992; Van Iterson \& Olie, 1992; Visser, 1992; Van Dijk \& Punch, 1993; and Van der Klink \& Mulder, 1995/. Each of these will be discussed below.

\section{The structure of decision power within Dutch companies}

The high score of the Netherlands on femininity is reflected in the way decision power within Dutch companies is organized. There is a strong emphasis on consensus, negotiation and consultation between employees, top management and shareholders/owners, which is institutionalized by a number of laws. The first interest group, emplayees, is represented through the works council ('Ondernemingsraad"). Every organization in the Netherlands with more than 100 employees is by law obliged to install a works council. Smaller organizations with more than 35 emplovees also have works councils, but the latter's authority is less extended. The members of the works council - all non-management employees - are elected by the entire workforce. Management needs to consult the works council on important policy matters that affect the entire company. There are however also issues in which top management needs the explicit consent of the works council. This is the case in all decisions concerning personnel policy and fringe benefits. The precise competencies and duties of the works council are specified in the Works Councils Act (Wet op de Ondernemingsraden, 1979 ).

The second interest group, top management $\mathrm{t}_{\mathrm{s}}$ in large companies divided into two different bodies: the Supervisory Board "Raad van Commissarissen"] and the Executive Board ('Raad van Bestuur'). Large companies are defined as firms with a turnover over 225 million Dutch Guilders, more than 100 employees and a works council (Structure of Corporations Act, 1971). Although both boards have to take care of the interest of the company as a whole and not of one group of stakeholders in particular, their function is different. The Executive Board is concerned with the actual management of the company, while the Supervisory Board - as a separate entity advises and supervises the Executive Board. The Executive Board has to obtain consent from the Supervisory Board on matters affecting the long term policy of the company. Furthermore the Supervisory Board can hire and fire members of the Executive Board. A vacancy on the Superwisory Board is filled through cooptation: i.e., the present members of the Board elect new members. Their choice, however, is subject to consent of the works council and the General Assembly of Shareholders ('Algemene Vergadering van Aandeelhouders").

The third interest group, the shareholders/owners of the organization, meet once 
a year in the General Assembly of Shareholders to evaluate the performance of the Executive Board. This assembly decides upon potential hiring and firing of members of the Supervisory and Executive Board. So, in managing a large corporation the Executive Board has to consult and cooperate with the employees organized in the works council and their 'superiors' organized in the Supervisory Board on all important decisions. The owners evaluate their overall performance once a year. But even in smaller organizations, with fewer than 100 employees, the consultation structure described above is effectuated. Although the authority of the works council is less extended and a Supervisory Board is absent, the influence of the shareholders/owners is generally somewhat larger.

As a logical consequence of the structure of decision power, Dutch management style reflects an emphasis on consensus. On the one hand, the managier has to be problem-solving and task-oriented (which tends to fit a masculine culture); on the other hand, his subordinates expect him/her to be considerate and to nurture group relations (which suits a feminine culturel. Throughout the organization the emphasis on consensus is also manifest in the reward system. It was argued previously that in a feminine culture rewards were distributed mainly on the basis of equality according to need. For the companies we investigated in the Netherlands this seemed indeed the case: when all categories of personnel are averaged, an individual bonus based on results was present in only $33 \%$ of the companies in our sample. If the management level is not counted, this percentage even drops to $23 \%$.

\section{Dutch industrial relations}

The tendency towards consensus and stable relationships is also present in Dutch industrial relations. Table 5.2 reveals that, compared to Great Britain and the USA, relatively few working days were lost through disputes in 1991. In fact the only EC member states losing fewer working days are Germany (excluding GDR) and Luxemburg (CBS, 1994 ).

\begin{tabular}{|l|l|}
\hline Countries & $\begin{array}{l}\text { Working davs lost through disputes in } 1991 \text { per } \\
1000 \text { employees }\end{array}$ \\
\hline The Netherlands & 17 \\
\hline Great Britain & 34 \\
\hline United States of America & 40 \\
\hline
\end{tabular}

Table 5.2: Working days lost through disputes in 1991 per 1000 employees

Labor unions in the Netherlands are organized according to branches of ind ustry rather than individual crafts, so there are relatively few, fairly pluralist unions. This pluralism is historically determined, since the unions were tied to confessional or ideological loyalties across social boundaries. In the 1970 s, mergers between unions took place 
which diffused a number of the confessional or idealogical boundaries. At this moment, the largest union is the FNV ('Federatie Nederlandse Vakverenigingen'), which covers $60 \%$ of the workers that joined a union. This union came into existence after a merger between the socialist and catholic unions in 1976. The second largest union is the CNV ('Christelijk Nationaal Vakverbond') which is of protestant denomination but also includes the catholic and protestant unions of civil servants. In 1993, its membership rates amounted to $18 \%$ of the unionized work force. Finally. the third largest union is the MHP ("Vakcentrale voor Middelbaar an Hoger Personeel'), the trade union federation for staff and managerial personnel of which onlly $8 \%$ of the unionized workforce is a member. Overall, the union membership in the Netherlands is fairly low with only $25 \%$ of the dependent labor force being organized in unions ICBS, 1994).

Employers in the Netherlands are represented in employers' associations. The largest assaciations are the VNO ('Verbond van Nederlandse Ondernemingen') and the NCW (Nederlands Christelijk Werkgeversverbond'). Small and medium-sized firms have their own employers associations, the largest being the KNOV ("Koninklijk Nederlands ondernemers Verbond" . These employers associations can be viewed as umbrella organizations for a number of strong industry associations.

The negotiations between this limited number of employers" associations and trade unions are rather centralized with active participation of the government. Since Dutch labor organizations have a tradition of "broad unionism", the unions focus on broader social and economic issues than implied by the interests of workers alone. These issues are often part of the consultation process in which labor unions and employers" associations meet in two public institutions, the Labor Council ("Stichting van de Arbeid") and the Social and Economic Councill ('SER, Sociaal-Economische Raad'1. These public bodies consist of employers, employees and government representatives who regularly meet to confer and to settle a large range of issues. Generally these meetings are being considered as producers of pre-cooked new bargaining positions. Since the employers' associations and the labor unions operate in a broader context than just on behalf of the 'capitalists' and the 'workers', management and union are not necessarily adversaries in these negotiations but often cooperating partners. The legally-prescribed collective bargaining process between labor unions and employers' associations usually results in collective labor agreements ICAO: "Collectieve Arbeids Overeenkomst'). These collective labor agreements not only deal with wages, but a large number of other issues are being subject to the negotiations as well (such as vocational training and early retirement procedures). These agreements function as minimum standards that apply to entire industries, and they are formally sanctioned by the Dutch Secretary of Social Affairs for all workers in the industry. So, they pose the lower boundary upon which companies base part of their HRM policies. Approximately 750 different agreements were set in 1986 , Govering $84 \%$ of the Dutch employees, of which 191 agreements were industry-wide 
while the remainder applied to single companies only (Albeda \& Dercksen, 1989). Participation within the organization operates through the previously described works council ("Ondernemingsraad').

\section{The Dutch labor market}

The Dutch labor market has a number of paradoxical features. The population of 15.3 million Dutchmen consists of a workforce of 7.2 million persons. The unemployment rate in 1993 amounted to $7.7 \%$ of the Dutch workforce, which is like elsewhere in Western Europe being considered as the most important economic issue. After the recession in the early 1980 s (with an unemployment rate of $10.4 \%$ in the low point of 1984) and the recovery in the beginning of the 1990 s (with $6.6 \%$ unemployment in the hausse of 1991) the unemployment rate is rising again. Even worse, the structural unemployment rate and the percentage of long-term unemployed in the workforce are both increasing as well (Kerckhoffs, De Neubourg \& Palm, 1994). Also Dutch labor costs are above the average European level. In 1991 the average hourly wage in industry was 22.80 Dutch Guilders, while the total hourly wage costs amounted to 41.78 Dutch Guilders (CBS, 1994). Of the total labor cost per company, $74 \%$ is spent on gross wages, $14 \%$ on social security and the remainder, $12 \%$, on fringe benefits and externally hired personnel (Coopers \& Lybrand, Berenschot, 1994). The net-income of the workers, however, is relatively low. This is partly due to the relatively extensive Dutch collective sector (including social security benefits). The extremely high social security spending, which amounted to $35.1 \%$ of the national income in 1992, takes a prominent place on the political agenda by now.

Another important characteristic of the Dutch labor market is that employee mobility is rather low. Average company tenure of $72 \%$ of the workforce exceeds 10 years (Wolfs, 1992). This low mobility can be attributed to a number of factors (King, 1990). First, it is considered nat done to frequently move to other companies since this would imply disloyalty to the firm. In addition, companies will think twice before tempting other's emplovees with powerful employers' associations nearby which disapprove of such tactics. Finally, pension rights, that are highly valued, are not easily transferred from one company to another. According to a Dutch study into personnel management practices, external mobility (which is the sum of the percentage of people entering and leaving the organization) amounted to $14.3 \%$ in 1993 (Coopers \& Lybrand, Berenschot, 1994).

The largest employer in the Netherlands is the service sector (including the government), that employs $72 \%$ of all the working population. Manufacturing industries provide jobs to $26 \%$ of the working population and $1.6 \%$ of the working population works in agriculture and fisheries (CBS, 1994). 


\section{Economic demography of the Netherlands}

The structure of Dutch business is characterized by the shape of an hour-glass (Van Iterson \& Olie, 1992: 98) with a large number of small and medium-sized firms on the one hand and a limited number of very big multinationals on the other. In all the economic sectors only $0.8 \%$ of the companies employ more than 100 employees (CBS, 1994) and are thus considered large. How large the few multinationals actually are is illustrated by the fact that the three largest companies according to number of employees - of which two are jointly Dutch and British owned - employed 301,000 (Unilever), 287,555 (Philips) and 137,000 (Shell) people in 1990 respectively Financieele Dagblad, 1991). Furthermore, there is a skewed sectoral distribution with a strong focus on agro-related, trade, service and chemical industries. The service sector has the highest ratio of employees to sales. Table 5.3 provides illustrative figures on the size distribution (in terms of the number of firms per employment class) of a number of sectors in 1993 (source: CBS, 'Statistiek van het ondernemingsbestand 1993', 1993).

\begin{tabular}{|c|c|c|c|c|c|c|c|}
\hline \multirow{2}{*}{ Industry } & \multicolumn{7}{|c|}{ Number of employees } \\
\hline & $1 \cdot 10$ & $10-20$ & $20-50$ & $50-100$ & $\begin{array}{l}100- \\
200\end{array}$ & $\begin{array}{l}200 \\
500\end{array}$ & $>500$ \\
\hline $\begin{array}{l}\text { Bullding and } \\
\text { construction }\end{array}$ & 17.118 & 3,642 & 2,543 & 728 & 267 & 96 & 30 \\
\hline $\begin{array}{l}\text { Trade, catering } \\
\text { \& repairment }\end{array}$ & 100,590 & 8,628 & 4.738 & 1,119 & 457 & 228 & 102 \\
\hline $\begin{array}{l}\text { Transportation } \\
\text { \& } \\
\text { communication }\end{array}$ & 8,782 & 1,717 & 1,339 & 415 & 161 & 69 & 41 \\
\hline $\begin{array}{l}\text { Banking. } \\
\text { insurance \& } \\
\text { proffessional } \\
\text { services }\end{array}$ & 36.489 & 2,778 & 1,740 & 616 & 297 & 193 & 117 \\
\hline Food \& drink & 3,884 & 688 & 460 & 192 & 125 & 106 & 37 \\
\hline Textile & 473 & 108 & 121 & 49 & 36 & 18 & 4 \\
\hline Paper \& pulp & 78 & 35 & 45 & 37 & 30 & 34 & $\theta$ \\
\hline Chemicals & 245 & 72 & 92 & 64 & 55 & 48 & 32 \\
\hline
\end{tabular}

Table 5.3: Size distribution in a number of Dutch industries in 1993

\section{The Dutch education system}

The Dutch education system from which companies recruit new employees is very stratified, though not elitist or marked by large social differences. Virtually every different level of education guarantees sound standards of knowledge and skills of employees, independent of the institution the student graduated from. Although an 
apprentice system exists and expediting initiatives have been taken in recent years, both only play a minor role. However, since companies in the Netherlands feel that the Dutch vocational education system is inadequately matched to the demand side of the labor market, they frequently design their own in-house programs directed towards company-specific knowledge and skills. The in-house programs have a share of $26 \%$ in the total of participants in vocational education and training activities. The regular education system covers $43 \%$ of this market, while private institutions take the remaining $31 \%$ with seminars and training that seek to bridge the aforementioned gap with company demands (Thijssen, 1988).

\section{Future developments}

Changes in industrial relations occur only gradually in the Netherlands. The Dutch labor market is generally being viewed as extremely inert, which is not surprising considering that changes in one part of the system immediately affect all the other parts (Lane. 1994). However, now it is widely understood that the trend toward further decentralization of collective agreements to the company level is structural. Although, according to Visser (1989), the extent and effect of this decentralization trend differs over economic sectors. In sectors that are subject to intensifying international competition - such as chemicals or consumer electronics where the total quality concept is crucial - decentralization of labor relations will be most prominent. Professilonal personnel managers and the works council will play a dominant role in determining social working conditions and personnel policy. So in these sectors this development clearly enlarges the flexibility of companies and employees to compose company-specific arrangements. In sectors that operate within more stable markets and/or are more geared towards the domestic market, like metal and retailing, it is unlikely that traditional labor relations with collective bargaining between trade unions, emplovers and the government will change drastically in the short run. Then finally in the collective and subsidized sector, where union membership is highest and no decentralization trend is as of yet present, labor relations will remain fairly unaffected in the near future.

\subsubsection{The British business system}

British business life has some features that distinctively differ from the business environment in the Netherlands. The same six institutional characteristics that were discussed above are also expected to have the largest impact on HRM in Great Britain (Crouch, 1990 \& 1994; Randlesome, 1991; Edwards et al., 1992; Lane, 1992 \& 1994; Tayeb, 1993; Tyson, 1993; and Van der Klink \& Mulder, 1995/. These are discussed below. The discussion for Great Britain is somewhat shorter than for the Netherlands since, overall, the British firm is more institutionally isolated than its Dutch 
counterpart. The role of the British state is relatively limited, resulting in less legislation concerning industrial relations. Much more is left to the forces of the market. Note, moreover, that British national culture has already been discussed above.

\section{The structure of decision power within British companias}

The little state involvement has lead to business philosophies in which independence, voluntarism and arm's length relationships are key ingredients. Therefore, there is no consultation and negotiation process within British companies that is institutionalized by law. The employers avoided legislation which constrained their freedom to manage and the employees, of which the majority is a union member, wanted no state intervention that curtailed their power. The strong unionization, howewer, has lead to the underdevelopment of other bodies of worker representation llike Dutch works councils) in the companies. As far as representation of workers does exist, it takes place via the union personified by the shop stewards. The shop steward is a member of a work group who is elected to represent this group in dealings with management. They receive no support, however, from a legal framework. This system with a strong emphasis on independence is reflected in a facilitative managennent style. Employees expect to be able to work independently in a work environment that is geared towards creating the conditions in which they can increase their performance. Result-based reward systems are therefore more common in Great Britain than in the Netherlands. This was also expected on the basis of the fairly high score of Great Britain on the cultural dimension of masculinity. Fitting within the class consciousness in British society, managers mainly attribute their authority to position rather than expert knowledge. This is accepted by the employees as lang as the power derived from the autharity position is executed well.

\section{British industrial relations}

Whereas Dutch industrial relations tend towards consensus and negotiation as a result of the high score on the femininity dimension of national culture, British industrial relations exhibit many of the characteristics expected in a more masculine society. In addition. British industrial relations are strongly rooted in a history of little state involvement and high voluntarism. This implies that negotiations between emplovers and trade unions are not conducted within a legally defined framework, but are based on procedural rules that are made up by the parties themselves. This resulted in a skewed power balance between employers and trade unions in favor of the trade unions. Due to legislation in the 1980s ("Thatcherism") - such as the 1980, 1982, 1988, 1989 and 1990 Employment Acts and the 1984 Trade Union Act - the power of the unions was somewhat more controlled. Still, however, multiple unions that are organized by craft or industry exist. In 1990,23 unions with over 100,000 members operated in Britain, the three largest being the Transport and General Workers Union (T\&GWU) - with 1,223,891 members - the General Municipal Boilermaking and Allied 
Trades Union (GMB) - with 865,360 members - and the National and Local Government Officers association (NALGO) - with 744,453 members. As a result, it is not uncommon that multiple unions operate within one factory, not only bargaining with the employers but also with each other. The employers, on the other hand, are not very well organized and the government is not, like in the Netherlands, an active partner in the negotiation process. Due to the 'laissez-faire' attitude of the state. bargaining between management and unions is decentralized to the plant level. Negotiated agreements therefore rarely apply to industries at a national level. National collective bargaining is even viewed by the government as a restriction to labor mobility and being in conflict with the needs of individual companies. So, when agreements at a national level are reached, they posit no legally enforceable contracts. Furthermore, there are no consultative bodies at the national level in which the unions are invited to participate in discussing general social and economic issues that affect their members. As a consequence, unions adopt a fairly pragmatic attitude towards their role and fight for better pay and working conditions instead of engaging in more ideological battles. This situation results in negotiations where management and unions are adwersaries. This is perthaps why union membership has traditionally been high in Great Britain: about $50 \%$ during the 1980s. Also working days lost through disputes (Table 5.2) is much higher than in the Netherlands.

\section{The British labor market}

The British population of approximately 58 million consists of a workforce of 27 million people. The average umemployment rate in Great Britain amounted to $9.7 \%$ in 1992 with large discrepancies between the different regions. The highest unemployment rate, $11.3 \%$, can be found in the north, and the lowest, $7.8 \%$, in East Anglia. The largest employer in Great Britain, like in the Netherlands, is the service sector, providing jobs for $73 \%$ of the working population. Manufacturing industries employ $20 \%$ of the working population. Only $1.2 \%$ of the working popullation works in agriculture and fisheries (CSO, 1994). In 1981, when the last census in Great Britain was held, $17 \%$ of the people in employment worked part-time. Due to cuts in labor costs and a more flexible approach to employment, the percentage of people working temporary, part-time or through sub-contracting has probably increased (Hunter. McGregor, Macilnnes \& Sproull, 1993). Another characteristic of the British labor market that illustrates the government's free market philosophy is that workers under 21 enjoy no legal protection in the sense of, for example, minimum wages.

\section{Economic demography of Great Britain}

British industry is much more than the Dutch characterized by a dominance of large firms. The large firms have grown very much by American example, often resulting in diversification into unrelated business areas and markets. Take-over is relatively easy effectuated, due to the financial structure. Large shareholder positions in companies 
are often held by institutional investors whose focus is on short-term financial results. This emphasis on short-term performance has created a relatively 'open' market in trading of shares with an implicit threat of take-over by a conglomerate. Conglomerates are therefore more common in Great Britain than in the Netherlands. Large companies in Great Britain, being defined as companies with more than 100 employees, represent $6 \%$ of all manufacturing firms. In the Netherlands, only $0.8 \%$ of all the companies were in this size category. The three largest companies according to number of employees - of which one is jointly Dutch and British owned - employed 304.000 (Unilever), 217.373 (BAT Industries) and 138.149 (Grand Metropolitan) respectively (Financieele Dagblad, 1991). Table 5.4 provides illustrative figures on the size distribution (in terms of the number of firms per emplayment class) of a number of sectors in 1993 (source: CSO. "Annual abstract of statistics 1994', 1994).

\begin{tabular}{||l|c|c|c|c|c|c|c||}
\hline \multirow{2}{*}{ Industry } & \multicolumn{7}{|c|}{ Number of employees } \\
\cline { 2 - 9 } & $1-10$ & $10-20$ & $20-50$ & $50-100$ & $100-200$ & $\begin{array}{l}200- \\
500\end{array}$ & $>500$ \\
\hline Food \& drink & 5,963 & 1,296 & 1,156 & 618 & 474 & 428 & 214 \\
\hline Textile & 2,573 & 425 & 599 & 375 & 289 & 167 & 32 \\
\hline Paper \& pulp & 17,402 & 2,352 & 2,297 & 838 & 501 & 294 & 82 \\
\hline Chemicals & 2,073 & 432 & 529 & 348 & 253 & 184 & 119 \\
\hline
\end{tabular}

Table 5.4: Size distribution in a number of British industries in 1993

\section{The British education system}

The British education system is not as stratified as the Dutch, but more elitist. An apprentice system plays a larger role in Great Britain than in the Netherlands, although problems with this system diminish its importance somewhat. The most important problems are the external monitoring of standards, the union-determined rigidity of acquired skills and the declining investments in training and development due to past recessions. The odd situation has emerged in which high levels of unemployment and skill shortages co-exist. The investment in training and development in British companies has lagged behind most of their European counterparts due to the shortterm orientation of managers. Since, therefore, the attention of companies for the development of an internal labor market has been limited, it is very common that management promotion is gained through movement between firms. Private companies and govermmental bodies are taking modest initiatives, however, to encourage training. 


\section{Future developments}

Due to the legislation concerning trade unions in the 1980 s and the impact of foreign Japanese - direct investment some changes in industrial relations are taking place. Single union deals with companies are beginning to emerge in which the possibility of a strike to solve disputes is significantly diminished. If the trend in number of working days lost per 1000 employees from 1985 untill 1992 is examined, there indeed appears to be a significant decrease (Table 5.5).

\begin{tabular}{|l|l|l|l|l|l|l|l|l|}
\hline & 1985 & 1986 & 1987 & 1988 & 1989 & 1990 & 1991 & 1992 \\
\hline $\begin{array}{l}\text { Working days lost per } \\
\text { 1000 employees in } \\
\text { Great Britain }\end{array}$ & 299 & 90 & 164 & 166 & 182 & 83 & 34 & 24 \\
\hline
\end{tabular}

Table 5.5: Eight-vear average of working days lost per 1000 emplovees in Great Britain

Furthermore, the trend toward even further decentralization of labor relations to the company level seems to increase in response to demands for greater flexibility in local decision making. The question is whether the unions can internally reorganize so as to effectively follow this trend, so that representation and participation of the employees in the bargaining process is ensured. No changes, as yet, occur in the bargaining priorities of the union: increases in pay are still more important than other qualitative issues such as training and technology development. This and a presumed short-term orientation of management makes it difficult to implement working methods that meet the demands of the changing environment.

\subsection{The business system in relation to the components of Human Resource Management}

Although the national cultures of the Netherlands and Great Britain only differ significantly on the masculinity - femininity dimension, their business systems show considerable variety. And although in both countries a trend toward further decentralization of labor relations is present, the impact this will have on the managers' degrees of freedom to implement HRM will vary due to differences in present business systems. Crouch (1994) provides a framework in which he distinguishes six different types of branch or national level collective bargaining. The position of a country in the framework depends on the strength of organized labor and, related to this, the extent to which employers as well as employees are coordinated in employers' association and trade unions. When this framework is applied to position the Netherlands and Great Britain, based on the characteristics described in the previous section, the following picture emerges (Table 5.6). 


\begin{tabular}{|c|c|c|c|c|c|}
\hline \multirow{5}{*}{$\begin{array}{l}\text { Strength } \\
\text { of } \\
\text { organized } \\
\text { labor }\end{array}$} & \multirow[t]{3}{*}{ High } & 1. & $\begin{array}{l}\text { Unstable collective bargaining } \\
\text { Example: Gireat Britain }\end{array}$ & $\| w$ & $\begin{array}{l}\text { Tense reo-corporatism } \\
\text { Example: Sweden }\end{array}$ \\
\hline & & 11. & $\begin{array}{l}\text { Stable collective bargaining } \\
\text { Example: none in Europe }\end{array}$ & $v$ & $\begin{array}{l}\text { Stabie neomcorponatisn } \\
\text { Example: Gemany }\end{array}$ \\
\hline & & III. & $\begin{array}{l}\text { Ineffective labor organization } \\
\text { Example: France }\end{array}$ & Vil. & $\begin{array}{l}\text { Stable neo-corporatism } \\
\text { through social promotion } \\
\text { Example: tho Netherlands }\end{array}$ \\
\hline & \multirow[t]{2}{*}{ Low } & LoW & & \multicolumn{2}{|l|}{$H * g / n$} \\
\hline & & \multicolumn{4}{|c|}{ Extent to which employers' associations and trade unions exist } \\
\hline
\end{tabular}

Table 5.6: Six different types of branch or national level collective bargaining

Great Britain is characterized by unstable collective bargaining, while the Netherlands operates in a system of stable neo-corporatism through social promotion. The trend of decentralization of collective agreements to the company level will differ in impact and extent over these two types of systems (Crouch, 199.4). In Great Britain, companies will embrace the decentralization trend as this is likely to diminish the strength of the unions. In company-level bargaining, the employers have greater control over the level at which the interaction takes place. The unions have not vet concentrated their power at a company-level but have organization structures that' are still better suited to branch or national-level negotiations. A substantial risk of conflict however exists through shop floor workers taking autonomous action. Furthermore, the decentralization trend may be associated with a collapse of the higher-level bargaining structure, since no legal framework hinders these changes. This however also implies that national coordination of labor issues disappears as companies are given complete discretion on matters of pay and working conditions. Combined with the presumed short term orientation in British business, this results in an emphasis of companies on control (over costs) rather than on development (Crouch, 1994). The need to be innovative, however, seems to have pervaded at least the companies in our British sample already. In Chapter 3 , where the relationship between the competitive environment and the generic strategies was examined, they all obtained high scores on the environmental dimension "drive to innovate". Whether this perceived need to be innovative also applies to their personnel or human resource strategies, will be examined in Section 5.6 of this chapter.

In the Netherlands, characterized by stable neo-corporatism through social promotion, it would theoretically be easiest for employers to develop non-union personnel strategies, since the unions are relatively weak. However, due to the embeddedness of industrial relation institutions in national life, the legal framework and the consensus orientation, the need to challenge the existing structure is less apparent. So, although the trend toward company autonomy will increase, it will do so within existing national- or branch-level structures (Crouch, 1994). 
Although, at first sight, HRM is easier to implement in Great Britain than in the Netherlands due to the larger autonomy of the British firm, this is not necessarily the case. On the basis of the former characteristics of the Dutch and British business system, the feasibility of the implementation of HRM elements, - (i) recruitment and selection, (ii) performance appraisal and compensation and (iii) training and development - can be discussed. The discussion provides onlly a very generalized illustration of the context in which personnel policies are formulated, differentiation by size and sector within the countries are not taken into account.

The first HRM component - recruitment and selection - consists of all the methods involved in obtaining and retaining human resources (Schuler, 1987b). The two primary recruitment methods are internall search versus external search. In the Netherlands, where mobility between companies is fairly low, internal search is likely to be more prominent than recruitment from external sources. This also implies thatt the recruitment function is less important than the other two HRM components. Compared to the Netherlands, recruitment in Great Britain will be more externally focused, mainly due to the more flexible approach to employment and the large percentage of people working part-time. This does not automatically imply that internat recruiting is less important, however (Gasperz, 1993). Selection methods are therefore likely to be less extensive in the Netherlands than in Great Britain. When a large internal labor market operates in the Netherlands, recruitment will take mainly place at entry level positions (Schuler, 1987b), rendering extensive selection methods less essential.

Performance appraisal and compensation, the second HRM component, comprises all activities related to estimating the performance of employees and the associated compensation. This is an important activity in assessing the extent to which the emplovee contributes to the achievement of the organization's goals (Schuler, 1987b). Although based on the business system features of the Netherlands and Great Britain no conclusions can be drawn on a potential difference in the intensity with which this activity is conducted in both countries, the content of performance appraisal and compensation is likely to be different. Due to the far-reaching decentralization of labor relations to the company level in Great Britain, companies have considerable autonomy in determining how performance of an employee is evaluated and to which compensation package this will be linked. The profitability of the company is likely to be a determining factor. And although unions may not agree with the size of the compensation, the profit link is - also due to the masculine culture - not necessarily rejected. Performance-related pay structures are therefore expected to be more common in Great Britain. Because performance-related pay implies that competition between employees to achieve the best performance prevails - as well as the knowledge that if the performance criteria are not met, the employee can be fired this reward system is much harder to implement in the Netherlands. That is, the underlying assumptions are in conflict with Dutch business culture, where a consensus 
orientation prevails. Furthermore, although in the Netherlands decentralization of industrial relations takes place, the government, employers and employees also consider their societal responsibility for decreasing unemployment and industrial disability. This leads to a greater protection in terms of employment security of also the less-performing employees. Performance is therefore more aften tied to tenure than to performance.

The activities concerning the third HRM component, training and development, are also expected to differ between the Netherlands and Great Britain. Training and development activities are defined as those activities that are geared toward improving employee performance by increasing the employee's skills and knowledge (Schuler, 1987 bl. Employee development, either by means of vocational training or company training programs, play a leading role in Dutch companies because they feel that the Dutch vocational education system is inadequately matched to their demands. In Great Britain. the need for training and development is also recognized and considered important, but investments in training and development have been lagging behind.

The relationships discussed are summarized in Table 5.7. This table intentionally portrays a black-and-white picture of the differences between the Netherlands and Great Britain, while studies conducted in the Netherlands on, for example, the existence or absence of internal labor markets and their relation to the HRM components indicate a complicated grey picture (Wolfs, 1992; Gasperz, 1993; Ten Have, 1993; and Schwan, 1993). It is beyond the scope of this chapter, however, to analyze this in detail.

\begin{tabular}{|c|c|c|c|}
\hline \multicolumn{2}{|c|}{ HRM components } & The Netherlands & Great Britain \\
\hline 1. & $\begin{array}{l}\text { Recruitment and } \\
\text { selection }\end{array}$ & $\begin{array}{l}\text { Emphasis on internal search, } \\
\text { external search receives less } \\
\text { emphasis }\end{array}$ & $\begin{array}{l}\text { Emphasis on external search, } \\
\text { but also use of internal search }\end{array}$ \\
\hline 2 & $\begin{array}{l}\text { Performance appraisal } \\
\text { and compensation }\end{array}$ & $\begin{array}{l}\text { Performance related fewards are } \\
\text { uncommon. Compensation most } \\
\text { often based on tenure. Extensive } \\
\text { package of benefits }\end{array}$ & $\begin{array}{l}\text { Performance related to rawards } \\
\text { fit in business culture. Package } \\
\text { of benefits is likely to be less } \\
\text { axtensive }\end{array}$ \\
\hline 3 & $\begin{array}{l}\text { Training and } \\
\text { development }\end{array}$ & $\begin{array}{l}\text { Cirucial activity in which a lot is } \\
\text { invested }\end{array}$ & $\begin{array}{l}\text { Less altention has been } \\
\text { devoted to this activity. } \\
\text { althowgh meed to increase } \\
\text { investments is recognized. }\end{array}$ \\
\hline
\end{tabular}

Table 5.7: Emphasis on HRM components in the Netherlands and Great Britain based on business system features

To examine whether these differences can indeed be observed between the Netherlands and Great Britain in our sample, the data for the Netherlands and Great Britain were combined. Although the variables measured in Great Britain and the Netherlands resemble rather closely, the specific items underlying the variables and the 
employee level at which some of the variables were measured vary somewhat. So, differences were only examined using those items that were similar for both countries. Where the employee levels diverged, averages were calculated. When different scales were employed, answers were recoded. The original questionnaire items used in both countries are presented in Appendix B.

Fisher Exact tests for $2 \times 2$ tables indicate that significant differences between Great Britain and the Netherlands exist on four items. The variables on which the countries differ all belong to the HRM components recruitment and selection on the one hand and performance appraisal and compensation on the other. The first item relates to recruiting new personnel. The Dutch companies use services of consultants or headhunters and personal recommendation significantly $(p=0.071$ and $p=0.022$, respectively) more than their British counterparts. This is opposed to the above reasoning, where external search of potential job candidates was expected to be more frequently employed in Great Britain. This leads to the conclusion that in our sample lower mobility between companies does not necessarily result in a decrease of the use of external search methods. Sorge (1992) provides an explanation of the frequent hiring of consultants in the Netherlands by linking this to two features of the Dutch business system that were discussed previously: a preference for social equality and peer control. Since these two features were violated by the requirements of the postwar emphasis on economies of scale, division of labor and automation, a possibillity is now created to eliminate the mismatch between existing social values in Dutch society and the control of personnel in organizations: as a result of the changing environment, the need to be flexible and to increase the emphasis on value added (rather than low cost) has increased. Organization and human resource consultancy firms have sprung up like mushrooms to fill the perceived gap, and turn these features of Dutch social organization into a competitive advantage for Dutch firms. The second item, relating to selection, on which a difference between the Netherlands and Great Britain is detected is the existence of a career plan. A career plan for every different llevel of employees is more predominant in Great Britain than in the Netherlands $(p=0.085$ for the management level, $p=0.040$ for middle managers, $p=0.0022$ for other employees and $p=0.002$ for production workers). This result is mot surprising when the characteristics of the British business system are taken into account. Societal values captured in the masculinity dimension result in a large emphasis on career advancement (Tayeb, 1993). Furthermore, the autonomy that British companies possess and the emphasis on independence, discussed in the structure of decision power within British firms, results in a facilitative management style. Superiors are not expected to look after their employees, but should rather present the employee with such a work environment that they can better perform their tasks. A career plan is a tool with which this can be achieved. The next two items relate to the HRM component of performance appraisal and compensation. For one, salary related to results is used significantly more in Great Britain on the level of middle management. 
$(p=0.040)$, other emplovees $(p=0.040)$ and production workers $(p=0.006)$. Again. this result confirms the proposition discussed above. In Great Britain, performancerelated reward systems are more common (Guest, 1992) and their introduction is stimulated by the decentralized nature of industrial relations, the short-term orientation of British business and the need to quickly realize a significant return on inwestment (Tayeb, 1993). Finally, differences in fringe benefits emerge on three items. Insurance facilities are offered significantly more in the Netherlands $(p=0.006)$, which seems to be in line with the more 'care for" culture. Finance facilities and company shares are provided more in Great Britain ( $p=0.079$ and $p=0.006$, respectively). The increasing emphasis of British business on employee-sharing schemes is facilitated by recent legislation (Guest, 1992) and, again, in line with the dominance of performance-related incentives.

The lack of significant differences between the Netherlands and Great Britain in the third HRM component, training and development, seems to be surprising. It should be noted, however, that the question regarding training and development was limited to whether or not the need for training was systematically examined. That this is done to an equal extent in both countries, does not guarantee, of course, that training and development activities are also implemented to an equal extent.

As the discussion in this section indicates, the question whether business system features enhance or prohibit the adoption of HRM in the Netherlands and Great Britain cannot be answered by a simple yes or no. In both countries distinct societal effects (Sorge, 1991) are present that influence the way in which personnel is managed. But although the actual HRM practices differ over both countries; all firms may share the goal of creating a competitive advantage through people. When the approaches taken in the Netherlands and Great Britain are categorized according to Storey (1992), Dutch companies are more likely to adopt a soft approach to HAM with an emphasis on personnel as human beings, while British companies are more likely to adopt a hard approach with an emphasis on personnel as a resource. This also implies that by looking at the content of HRM practices alone it remains difficult to judge whether HRM rather than traditional personnel management is indeed practiced. Therefore an analysis of a more comprehensive level at which the societal effect has less direct impact is needed to trace a potential shift toward HRM. This is the topic of Secition 5.4

5.4 Types of personnel or HRM strategies: does strategic integration and decentralization exist?

In Section 5.1 three principles were presented that together form the basis of Human Resource Management. In Sections 5.2 and 5.3 the business systems of the Netherlands and Great Britain were briefly described, and the consequences for the 
implementation of HRM components were examined. Whether the companies in our Dutch and British sample actually move from "traditional" personnel management to HRM, is discussed in this section.

There are many different ways in which researchers have attempted to capture a potential movement from 'traditional' personnel management to HRM IGuest, 1990 . To explore the situation in the Netherlands and Great Britain a qualitative approach is taken. The purpose of the qualitative analysis is to reveal how the organizations label their personnel function (Guest, 1990 \& 1987), where the personnel department is positioned in the structure of the organization (Brewster \& Larsen, 1992; and Storey, 1992) and whether personnel is specifically considered when the general strategic objectives of the organization are discussed (Schuler, 1992 \& 1990). The Netherlands and Great Britain are examined separately because the data obtained on personnel policies are not comparable on all issues. Furthermore, the difference in the respective contexts within which personnel policies are formulated, merits a separate discussion. Although the outcome of this qualitative research provides merely anecdotal evidence on the potential existence of HRM, it does clarify how the companies interviewed regard their personnel function.

\subsubsection{Types of personnel or HRM strategies in Dutch food \& drink and chemical companies}

The Dutch data used in this analysis are collected through interviews with personnel directors and inspection of annual reports, recruitment brochures and internal company documents in 1991 and 1992.

\section{Food \& drinks}

In the food \& drink industry seven companies were examined of which four were a division ar business units of a larger corporation. The average number of employees in the four corporations was 4,575 employees at the beginning of 1992 (with a standard deviation of 2,732 employees, and a range from 825 to 7,077 employees). The lower unit companies (n is 5 with 2 observations missing) employ on average 465 people (with a standard deviation of 470 , and a range from 100 to 1,270 employees).

Of the seven companies only one - with a Harvard alumnus as CEO, by the way - attaches the name Human Resource Management Department to its personnel function. Furthermore, this company explicitly mentions the importance of its employees in its mission statement. Although this expression of an HRM philosophy indicates how the company treats and values people, it does not automatically imply that HRM policies, programs and practices are indeed implemented (Schuler, 1992). No additional information was available, however, on whether an HRM strategy was actually implemented. 
The other six companies all have a Personnel \& Organization Department taking care of their personnel. Although the term HRM was nowhere explicitly mentioned, in half of these companies features of HRM could be detected. One very important indicator of a strategy-personnel link is that in two of these organizations the personnel manager is actually a formal member of the management team. This indicates that at least formally there is a relatively high level of strategic integration within these companies (Brewster \& Larsen, 1992). Furthermore, in all three companies management development, training and development, individualizing of working conditions and selection based on a company culture-personality" fit were stressed. Still another feature is that personnel policy was decentralized to the unit where production and marketing decisions were by and large made autonomously, which also indicates a relatively high level of devolvement (Brewster \& Larsen, 1992) in the sense that the personnel function delegates responsibility to line managers. This is illustrated by the remark in one of the companies ${ }^{r}$ annual reports that, concerning training and development, the personnel specialists should merely act as brokers between the employee(s) and management.

In the remaining three companies, features of HRM are less evident. Two of these companies, however, were interviewed less than a year after a merger took place, implying the organization was still in a state of flux. The personnel department was not very decentralized (vet). In one of these two companies, the personnel department was shared by two divisions; in the other company a personnel department was present in the division but could only operate within the context of a centrally-established personnel policy. Investments in management development and training and development were considered necessary in both companies, but were not yet implemented. The third company in which HRM does not seem to be present, is a relatively small independent company with 160 employees in the Netherlands. It is an example of the many small firms that flourish in the Netherlands in which personnel management is less professionalized and occurs in a more cooperative and corporatist context in line with Dutch values (Sorge, 1992). For example, one way employers and employees communicate is through the 'Personnel Council', where all matters concerning employees are discussed. Because of the relatively small size, interaction and cooperation between line management and the personnel function can prevail side by side a rather centralized personnel function.

From this one could conclude that the companies in the food \& drink industry differ remarkably in the degree of strategic integration and decentralization. A higher degree of strategic integration at the business unit or division level seems to correlate with decentralization in three cases (and vice versa: a low degree of strategic integration correlates with centralization). For the existence of HAM in the seven companies a partial shift from 'traditional' personnel management to HRM could be observed in four companies - although only one introduced the HRM-label - while this is not the case in three firms. These results are summarized in Table 5.8. 


\section{Chemicals}

In the chemical industry, five companies were examined of which four were a division or business unit within a larger group. They are embedded in organizations with an average number of employees of 29,350 at the beginning of 1992 (with a standard deviation of 26,045 employees, and a range from 2.400 to 65,000 employees). The lower unit companies have an average number of 672 employees in is 4.1 observation is missing), with a standard deviation of 854 employees and a range of 161 to 1950 employees.

None of these five chemical companies referred to the personnel function as their Human Resource Department. In all of the cases, the traditional Personnel and Organization label was sustained. In one of the companies' recruitment brochures, however, human resource management is mentioned as a vital strategic function. Surprisingly, this was not directly reflected in the organization of personnel at the business unit level. Although job rotation programs, career development, training and the creation of an internal labor market were considered to be important, personnel decisions were made at a division level - leaving little influence for the business unit managers. So, despite the HRM elements at the division level, the level of strategic integration and decentralization was only intermediate within the business unit (where production and marketing decisions were made fairly autonomouslyl. Neither was the personnel manager a formal member of the management team in any of the companies, divisions or business units. Personnel and Organization served in all but the above mentioned company as a staff department, focusing on career planning. management development and job rotation programs. These activities all contributed to the desire of the companies to create their own internall labor market for employees at the management level.

\begin{tabular}{|l|l|l|}
\hline The Netherdands & $\begin{array}{l}\text { Higher fevef of strategic } \\
\text { integration }\end{array}$ & $\begin{array}{l}\text { Lower level of strategic } \\
\text { integration }\end{array}$ \\
\hline $\begin{array}{l}\text { Higher level of } \\
\text { decentralization }\end{array}$ & Afood \& drink companies* \\
\hline $\begin{array}{l}\text { Lower tevel of } \\
\text { decentralization }\end{array}$ & \begin{tabular}{l}
3 chemical companies \\
\hline
\end{tabular}
\end{tabular}

In all of these organizations, however, evidence is found that programs fitting within the HAMphilosophy are implemented.

Table 5.8: The level of strategic integration and decentralization in Dutch firms

From the above, it can tentatively be concluded that, although the level of strategic integration appears to be fairly low, programs fitting within the HRM philosophy are indeed implemented in each company interviewed. The level of decentralization appears to be relatively high in all but two cases, since most HRM related programs 
are initiated and implemented at a fairly decentralized level. So, although none of the chemical companies indicates the use of HRM explicitly, programs fitting within the HRM philosophy were present or were being developed. One has to be careful, though, that because of the low level of strategic integration no gap arises between these programs and the strategic needs of the organizations (Brewster \& Larsen, 1992). These results are summarized in Table 5.8 as well.

The results presented in Table 5.8 are more pessimistic as to the actual integration of the personnel function and corporate strategy than findings of Van Sluijs \& Den Hertog (1992). They also tried to establish the degree of strategic integration of the personnel function by investigating whether in the Netherlands the personnel function is actually involved in the process of strategy making. Of the twenty-five companies they inferviewed, there was just one that was concerned with the administrative control of personnel without any relation to the strategic aspects of personnel. Eleven companies derived their personnel policy from the formulated strategy. The personnel departments were not actually involved in the strategy process, but they tried to design their personnel function consistent with the strategy. A mutual influence of personnel policy and strategy making was traced in nine companies. And, finally, in five companies a dynamic, interactive relationship was present between the personnel function and the strategy making. From this, it can be concluded that in their sample the majority of companies attempted to pursue an HRM, rather than a "traditional" personnel management approach.

\subsubsection{Types of personnel or HRM strategies in British food \& drink and chemical companies}

To explore a potential move from traditional personnel management to HRM in Great Britain, the level of strategic integration is estimated by determining whether the personnel department is involved from the outset in the development of a HRM or personnel strategy and whether this strategy is formally written down. The extent to which the personnell function is decentralized is derived from data indicating where decision making responsibility in each of the categories of choices in HRM is situated. Personnel policy is considered decentralized when the personnel function delegates responsibility to line managers. The qualitative description for Great Britain is less extensive than for the Netherlands, since only anonymous questionnaire data (Appendix B) and no secondary sources were available for the British companies.

\section{Food \& drinks}

In the British food \& drink industry five companies were examined that were all a division or business unit of a larger corporation. The average number of employees in the corporations was 90,013 employees in $1991 / 1992$ (with a standard deviation of 
118,612 employees and a range from 188,73 to 301,000 employees). The lower unit companies employ on average 4,598 employees ( with a standard deviation of 4,587 and a range of 744 to 12,000 employees).

Three of the five food \& drink companies in the British sample indicate to be involved in the formulation of an HRM strategy from the outset, but only in two of the companies this strategy is also officially written down. Who is primarily responsible for certain key HRM decisions in HRM is presented in Table 5.9. From the data it can be concluded that the personnel department and lime management have joint responsibility for career development, training and development plus recruitment of clerical and production personnel in the vast majority of companies. Even first-line supervisors have a vote in one company. Only recruitment of senior management and middle management is principally within the domain of the personnel department and senior management. Overall, one could conclude for the five food \& drink companies interviewed in Great Britain that, based on the available data, intermediate strategic integration and a relatively high level of decentralization appear to be present in the majority of companies.

\section{Chernicals}

In the British chemical industry three companies were examined that were all divisions or business units of a larger group. The average number of employees of the groups in $1991 / 1992$ was 46,112 employees (with a standard deviation of 63,294 and a range of 5,002 to 119,000 employees). The lower unit companies have an average number of 9,987 employees (with a standard deviation of 13,729 and a range of 1,100 to 25,800 employees).

In the chemical industry, two of the three companies interviewed state their involvement in HRM strategy-making from an early stage on. In these two cases, this is also officially written down. To determine the level of decentralization, data on the responsibility distribution of HRM decisions are summarized in Table 5.9. Senior management plays a large role in almost all of the HRM decisions in the three chemical companies in Great Britain. They are responsible for recruiting senior and middle management in all of the companies. The personnel department only plays a minor role in these decisions. The personnel department and line management are jointly involved in recruiting clerical and production personnel plus training and development, although senior management also considers training and development as part of their domain in two of the companies. Career development is either not present in the companies or no one accepts responsibility for these decisions, since line management is solely accountable in only one of the three companies interviewed. 


\begin{tabular}{|c|c|c|c|}
\hline \multicolumn{2}{|c|}{ HAM decisions } & \multirow[t]{2}{*}{ Chemicals } & \multirow[t]{2}{*}{ Food \& drinks } \\
\hline 1. & Recruitment & & \\
\hline 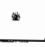 & Senior management primarily responsible for: & & \\
\hline$=$ & recruiting senior management & $100 \%$ & $80 \%$ \\
\hline- & recruiting middle management & $100 \%$ & $60 \%$ \\
\hline- & pecruiting clerical peirsonnel & $33 \%$ & $0 \%$ \\
\hline- & recruiting production workers & $33 \%$ & $0 \%$ \\
\hline 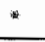 & Personnell department primarily responsible for: & & \\
\hline$\check{-}$ & recruiting senior management & $33 \%$ & $80 \%$ \\
\hline- & recruiting middle managementit & $33 \%$ & $80 \%$ \\
\hline- & recruiting clerical personnel & $100 \%$ & $20 \%$ \\
\hline- & recruiting production workers & $100 \%$ & $80 \%$ \\
\hline$*$ & Line management primarily respansible for: & & \\
\hline- & recrutting senior management & $0 \%$ & $20 \%$ \\
\hline- & recruiting middle management & $0 \%$ & $40 \%$ \\
\hline 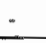 & recruiting clerical personnel & $67 \%$ & $60 \%$ \\
\hline- & recruiting production workers & $67 \%$ & $80 \%$ \\
\hline * & First lime supervisors primarily responsible for: & & \\
\hline- & recruiting senior management & $0 \%$ & $0 \%$ \\
\hline- & recruiting middle management & $0 \%$ & $0 \%$ \\
\hline- & recruating clerical personnel & $\% \%$ & $60 \%$ \\
\hline$=$ & recruiting production workers & $67 \%$ & $80 \%$ \\
\hline 2. & Career devellopment is responsibility of: & & \\
\hline- & senior management & $0 \%$ & $40 \%$ \\
\hline- & personnel department & $0 \%$ & $60 \%$ \\
\hline- & lire management & $33 \%$ & $80 \%$ \\
\hline- & first line supervisors & $0 \%$ & $20 \%$ \\
\hline 3. & Training and development is responsibility of: & & \\
\hline$\therefore$ & senior management & $67 \%$ & $20 \%$ \\
\hline ^ & personnel department & $67 \%$ & $80 \%$ \\
\hline$\therefore$ & Whe management & $67 \%$ & $100 \%$ \\
\hline . & first line supervisors & $33 \%$ & $20 \%$ \\
\hline
\end{tabular}

Table 5.9: Level of decentralization in HRM decision-making in British firms

For the chemical companies one could conclude that there is a fair amount of strategic integration. The level of decentralization in two companies appears to be low, 
however, due to the large involvement of senior management in almost all of the decisions and the selective delegation of authority to line management. To summarize the qualitative description for the British chemical and food \& drink companies, the level of strategic integration and decentralization for both industries is presented in Table 5.10 .

\begin{tabular}{|l|l|l|}
\hline Great Biflain & $\begin{array}{l}\text { Higher level of strategic } \\
\text { integration }\end{array}$ & $\begin{array}{l}\text { Lower lovel of strategic } \\
\text { integration }\end{array}$ \\
\hline $\begin{array}{l}\text { Higher lewel of } \\
\text { decentralization }\end{array}$ & $\begin{array}{l}3 \text { food \& drink companies } \\
1 \text { chemical company }\end{array}$ & 2 food \& drink companies \\
\hline $\begin{array}{l}\text { Lower level of } \\
\text { decentralization }\end{array}$ & 1 chemical company & 1 chemical company \\
\hline
\end{tabular}

Table 5.10: The level of strategic integration and decentralization in British firms

\subsubsection{Concluding remarks}

When the level of strategic integration and decentralization of personnel or HRM strattegies within the Dutch and British companies is compared, the following picture emerges (Table 5.11). Four types of personnel strategies are present in our sample. Strategies exhibiting a higher level of strategic integration and a higher level of decentralization are considered 'true' HRM strategies. 'Imposed' HRM strategies are characterized by strategic integration and centralization, while 'evolving' HRM strategies are defined by higher levels of decentralization and lower levels of strategic integration. Althougth the "imposed" and 'evolving" HRM strategies are no real HRM strategies according to the definition in Section 5.1, one has to keep in mind that aspects of HRM are indeed present in the form of strategic integration ("imposed" HRM strategies) and decentralization ('evolving" HRM strategies). A risk of the "imposed" HRM strategy however is that the implemented policies are well-integrated with corporate strategy but not particularly suited to the needs of the lower unit in the organization. A risk of the "evolving" HRM strategy is that this strategy diverges from the company"s generic strategy. The last type of HRM strategy is the traditional personnel strategy with hardly any strategic integration or decentralization.

Of the twenty firms in both countries on which data on personnel policies could be obtained, $40 \%$ pursues a 'true" HRM strategy. An "evolving" HRM strategy is followed by $25 \%$ and in only $5 \%$ of the companies an "imposed" HRM strategy is present. The remaining $30 \%$ of the companies did not adopt an HRM approach to personnel, but practices traditional personnel management. 


\begin{tabular}{|c|c|c|}
\hline & Higiner level of strategic integration & Lower level of strategic integration \\
\hline $\begin{array}{l}\text { Higher tevel of } \\
\text { decentralization }\end{array}$ & $\begin{array}{l}\text { "True" HRIM strategy } \\
4 \text { Dutch food \& drink companies } \\
3 \text { British food \& drink companies } \\
1 \text { British chemical company }\end{array}$ & $\begin{array}{l}\text { "Evolung' HPM strategy } \\
\text { 3. Dutch chamical companies } \\
\text { 2. British food \& drink companies }\end{array}$ \\
\hline $\begin{array}{l}\text { Lower level of } \\
\text { decentratization }\end{array}$ & $\begin{array}{l}\text { "Imposed" HAM sitrategy } \\
1 \text { British chemical company }\end{array}$ & $\begin{array}{l}\text { Traditional personnel strategy } \\
3 \text { Dutch food \& drink companies } \\
2 \text { Dutch chemical companies } \\
1 \text { British chemical company }\end{array}$ \\
\hline
\end{tabular}

Table 5.11: The level of strategic integration and decentralization in Dutch and British firms

\subsection{Personnel pollicies and generic strategies: how do they relate?}

A logical assumption following from the discussion on the level of strategic integration and decentralization of personnel policies would be that different external competitive strategy profiles are associated with different internal personnel (or HRM) policies. This is to be expected, based on the premises of HRM, since the chosen strategies have implications for HRM within organizations through the different emplovee characteristics that each strategy requires (Schuler, 1987a). Three problems emerge, however, in attempting to test such a proposition on the content of personnel policies. The first problem is that insufficient data are available on the actual implementation of the HRM components. In other words, in discussing differences over strategies, a distinction has to be made between the actual use of HRM instruments and the different objectives aimed to achieve with these instruments. For example, the extent to which certain recruitment and selection methods are used can be the same for two strategies. However, the emplovee searched for in a cost leadership strategy will be different from the one sought in a differentiation strategy: hence, the text or style of the advertisement in a newspaper or the way in which the interview is conducted may vary. Another example could be that not the fact that a career plan exists discriminates over strategies, but rather whether this is, for example, narrow or broad (Schuler, 1987a). So, with the available data it does not make much sense to test for differences between generic strategies on the HRM item level, since the items only contain information on the frequency with which the HRM instruments are used. The second problem is the mitigating effect of business system features on the different HRM requirements of the strategies, as was already mentioned in Section 5. 3. This will be subsequently discussed for the Netherlands and Great Britain.

In the Netherlands, the companies are cllassified according to Porter's (1980) generic strategies of cost leadership, differentiation, cost focus and differentiation focus. A fifth category emerged from the data, namely companies pursuing a combination of cost leadership, differentiation and focus. Porter (1980) refers to such 
companies as being stuck in the middle. In general, a cost leadership (focus) strategy requires intense supervision of labor, tight cost contral, frequent and detailed control reports, highly structured organizations and incentives based on quantitative targets. Training and development in a cost leadership strategy will be moderate, and specifically geared toward improving productivity (Schuler, 1987a). Especially the aspect of performance-based incentives as a method of personnel control will be moderated in the Netherlands (see Section 5.2 and 5.3). Also, the limited attention to training and development is uncharacteristic in the Netherlands. When these features of the Dutch business system are taken into account, it would aimost seem as if mosit organizations adopt the characteristics of the personnel policies that are required in a differentiation (focus) strategy, because in a differentiation (focus) strategy, selection and training are much more important to attract and retain high-quality skilled personnel. Furthermore, reward systems are not based on quantitative targets only (McKinlay \& Starkey, 1992). A possible conflict emerges for the companies pursuing a combination strategy of cost leadership, differentiation and focus. However, since the companies pursuing a combination strategy are all in the food \& drink industry. their main area of differentiation is presumably in marketing, where they create a favorable brand image that generalizes to a number of different product lines isee also Chapter 3). The production technology does not have to be altered substantially for every different product line. Therefore, this allows for economies of scale in marketing and production (Miller \& Friesen, 1986). The human resource implications of this strategy are that the requirements of a cost leadership strategy apply to emplovees working in or associated with production. The human resource strategy for other emplovees, including the managerial levels, should be in line with the requirements of a differentiation strategy.

Recall that the British companies are classified using Miles \& Snow's (1978) strategy typology of defender, analyzer, prospector and reactor. Characteristics of a defender strategy include a limited product line, single capital-intensive technology, a functional structure, skills in production efficiency, process engineering and cost control. These characteristics lead, among others, to the following consequences for the design of the human resource management system (Miles \& Snow, 1984): little recruiting above the entry level, extensive training programs aimed at skill building and compensation based upon position in the hierarchy rather than individual and/or group performance. This description would almost imply that the requirements of a defender strategy cannot be met in Great Britain when the features of the business system are considered, since - due to relatively high mobility - recruiting is likely to take place at all levels. Furthermore, training and development is not a prominent HRM activity in Great Britain, and rewards are more often based on performance (see also Section 5.2 and 5.3). Prospectors have diverse product lines, multiple technologies, a divisionalized structure and skills in product research and development, market research and development engineering. Their human resource management system is therefore 
oriented towards sophisticated recruiting at all levels, limited training programs and compensation based on performance (Miles \& Snow, 1984). So, these characteristics seem to be more in line with the features of the British business system. The analyzers try to combine aspects of the human resource management system of the defenders and the prospectors because they operate in separate markets that exhibit characteristics of either the defender or the prospector (Miles \& Snow, 1984). Finally, the reactors fail to pursue any consistent strategy. Therefore, no consistency is expected in their HRM system.

The third problem is the vagueness and even inconsistency that can be detected in the literature when the HRM requirements for the different generic strategies of Porter (1980) and Miles \& Snow (1978) are compared. Although it was argued in Chapter 3 that a defender strategy resembles a cost focus profile, a prospector strategy a differentiation profile and an analyzer strategy a combination of the former, different HRM requirements emerge. When they are positioned on the dimension of pro-activeness (Segev, 1989), the most pro-active strategy is the prospector followed by differentiation (focus). Least pro-active is the defender strategy followed by cost leadership. So, a defender is more conservative in, for example, product innovation. number of technologies and resource level than a cost leader. Although this is generally confirmed in the previous discussion, the different emphasis on training programs, which was described above, is surprising. But, again, due to the vagueness of description it is almost impossible to make a sound comparison, as may well be that the extensive training programs of the defender are specifically geared toward improving productivity. Almost the same reasoning applies to the differences between a differentiation and a prospector strategy. Since a differentiator is less pro-active than a prospector, issues such as operational efficiency, control system level, and quality are emphasized more. Prospectors pay more attention to, for example, the number of technologies employed and rate of growth. The HRM requirements described above confirm this reasoning, although again some confusion arises concerning training and development. Whereas in a prospector strategy limited training occurs because skilled personnel is acquired, in a differentiation strategy training and development is seen as important to retain the high-quality skilled personnel. It seems that research on the content of HRM policies and their relationship to the specific strategies beyond the conceptual framework level is fruitful to enhance our ability to make sound comparisons.

So, whether a relationship between the generic strategies and the content of the personnel policies pursued exists, cannot be determined with the available item level data. What can be examined, however, is how the extent of strategic integration and decentralization of the personnel function is associated with any of the generic strategies that the companies pursue. The question then becomes; is the management of personnel or human resources compatible with the strategy pursued? So, for companies where 'true' or "evolving" HRM strategies are pursued, it is assumed that 
these companies are better able to monitor developments in the competitive environment of the decentralized unit and thus can tailor their human resource management to these needs. In the case of a "true" HRM strategy, these actions are also in line with the strategy pursued. Which strategies are related to which types of HRM strategies is presented in Table 5.12. Inspection of the table leads to the conclusion that 'true' or 'evolving' HRM strategies are mainly associated with combination strategies of differentiation, cost leadership and focus, strategies of differentiation (focus) and analyzers. That a decentralized approach toward personnel is taken in these companies seems to be consistent with part of the control process associated with these strategies.

Although the firm pursuing a combination or analyzer strategy is mostly controlled in a centralized manner, marketing and brand management are decentralized (Miles \& Snow, 19841. It would therefore depend on the nature of the competitive environment whether the process or the marketing features are more important. In these cases, human resource management would support the strategies pursued when the environmental forces make marketing and brand image more important than the production process itself, rendering decentralization the dominant control process. This is examined in Section 5.6. This reasoning however also implies that the "imposed" HRM strategy, situated in the lower left quadrant of Table 5.12 , is not necessarily damaging to or inconsistent with the strategy pursued when the environment allows a centralized approach. So, the British chemical company pursuing a defender strategy does not have to suffer from the centralized nature in which personnel management is conducted, since the dominant control processes in a defender organization are centralized. Furthermore, the management of personnel is integrated with the strategy pursued. Whether a centralized approach fits with the environmental conditions is examined in Section 5.6. The odd one out is the Dutch food \& drink company with a cost leadership strategy and a 'true' HRM strategy. This however immediately points to an interesting paradox in the definition of a HRM strategy las opposed to a traditional personnel strategy). Since one of the basic distinguishing principles of a HRM approach is that the personnel policy is in line with the strategy pursued on the one hand and decentralized to line management or personnel departments lower in the organization on the other, this immediately limits the use of HRM approaches in organizations. The companies pursuing a cost leadership or defender strategy - and even the combination strategies where cost leadership is emphasized over differentiation - would be precluded and sentenced to adopting traditional personnel policies as the HRM strategy is inconsistent with their dominant control process. It would be rather odd if these companies could not manage their employees as human resources to obtain a competitive advantage. Therefore, it seems sensible to relax the decentralization condition depending on the generic strategy pursued. Since hardly any literature is available that discusses the content of certain HRM profiles and since the data in our sample do not allow the establishment of such profiles, a solution here is 
sought by defining three different HRM strategies: a "true" HRM strategy, an 'imposed" HRM strategy and an "evolving' HRM strategy. Further research into the content of these three types is of course necessary to define what on a content-level distinguishes HRM from a traditional personnel management approach.

\begin{tabular}{|c|c|c|}
\hline & Higher level af strategic integration & Lower lewel of strategic integration \\
\hline $\begin{array}{l}\text { Higher lewel of } \\
\text { decentratization }\end{array}$ & $\begin{array}{l}\text { 'True" HAM strategy } \\
3 \text { Dutch food \& drink companies with a } \\
\text { combination strategy of differentiation. } \\
\text { cost leadership and focus } \\
1 \text { Dutch food \& drink company with a } \\
\text { cost leadership strategy } \\
3 \text { British food } 8 \text { drink companies with } \\
\text { an anallyzer strategy } \\
\text { 1 British chemical company with an } \\
\text { andyzer strategy }\end{array}$ & $\begin{array}{l}\text { 'Evolving" HRM strategy } \\
2 \text { Dutch chemical companies with a } \\
\text { differentiation focus strategy' } \\
1 \text { Dutch chemical company with a } \\
\text { differentiation strategy } \\
2 \text { British food \& drink companies with } \\
\text { an analyzer strattegy }\end{array}$ \\
\hline $\begin{array}{l}\text { Lower level of } \\
\text { decentralization }\end{array}$ & $\begin{array}{l}\text { "Imposed" HRM strategy } \\
1 \text { British chemical company with a } \\
\text { defendier strategy }\end{array}$ & $\begin{array}{l}\text { Traditional persionnel strattegy } \\
2 \text { Dutch food \& drimk companies with } \\
\text { a differentiation focus strategy } \\
1 \text { Dutch food \& drink company with a } \\
\text { combination strategy of } \\
\text { differentiation, cost leadership and } \\
\text { focus } \\
1 \text { Dutch chemical company with a } \\
\text { cost focus strategy } \\
1 \text { Dutch chemical company with a } \\
\text { cost leadership strategy } \\
1 \text { British chemical company with a } \\
\text { defender strategy }\end{array}$ \\
\hline
\end{tabular}

Table 5.12: Generic strategies associated with the levels of strategic integration and decentralization

\subsection{The relationship between HRM strategies, the competitive enviromment and generic strategies}

In Chapter 3 two environmental dimensions are described. The first dimension describes a continuum from a "drive to cost control" (negative score on dimension 1) to a "drive to innovate" (positive score on dimension 1). Dimension 2 can be interpreted as a continuum from "drive to sophisticated marketing" (negative score on dimension 2) to a "drive to minimize marketing efforts" (positive score on dimension 21. As was already touched upon in the previous section, different environmental dimensions impose different demands on the organizations. So the question arises: does the HRM strategy reinforce the generic strategy pursued in the competitive environment that the company is facing? It is expected that HRM approaches to personnel management are most prominent in an environment where employees need 
to be innovative, flexible and willing to take risks: so, in terms of the environmemtal dimensions; in an environment with a drive to innovate and a drive to sophisticated marketing. In an environment with a drive to cost control and a drive to minimize the marketing effort, the need to implement HRM approaches is probably lowest. In this kind of environment the emphasis will remain on control of personnel rather than on development, since additional investments in personnel raise cost without immediately adding value.

To examine whether coherent combinations of the generic strategies. competitive environment and types of HRM strategies prevail, the companies in the clusters identified in Chapter 3 are inspected. The three clusters in the food \& drink industry and the four chemical clusters labeled with generic strategies and human resource policies are presented in Figure 5.2. The results for both industries will be discussed below. The numbers of the companies correspond to a short company description in Appendix A.

\section{Food \& drinks}

The relationship between the environmental dimensions and the types of HRM strategies portrays a pretty consistent picture. Especially dimension 2 seems to have an impact on whether or not HRM policies are adopted in the food \& drink industry: if one moves from top to bottom along the vertical axis, so from drive to minimize the marketing effort to a drive to sophisticated marketing, the adoption of HRM approaches seems to increase. Dimension 1 discriminates less than expected. Nevertheless, the companies that do not adopt HRM approaches to personnel are all located on the drive to cost control. Whether or not consistent HRM strategy-generic strategy pairs in their respective environments exist is examined per cluster (Table 5.13).

The food 8 drink firms in cluster I present a consistent group. Company 20 pursuing a combination strategy of cost leadership, differentiation and focus emphasizes differentiation over cost leadership, thereby adopting a decentralized system of control. This is consistent with the environment this company is facing, with a modest drive to cost control and an intermediate drive to sophisticated marketing. The two analyzers - companies 9 and 10 - that emplov evolving HRM strategies act in line with the organizational requirements of their generic strategy and the demands of the environment. It is unclear, however, whether the HRM initiatives taken actually support the strategy pursued. The question raised in Chapter 3 whether the companies in this cluster can be considered a strategic group, can be answered positively by this analysis. Not only do they pursue similar generic strategiles, they also attempt to strengthen these strategies by similar types of HRM strategies. 


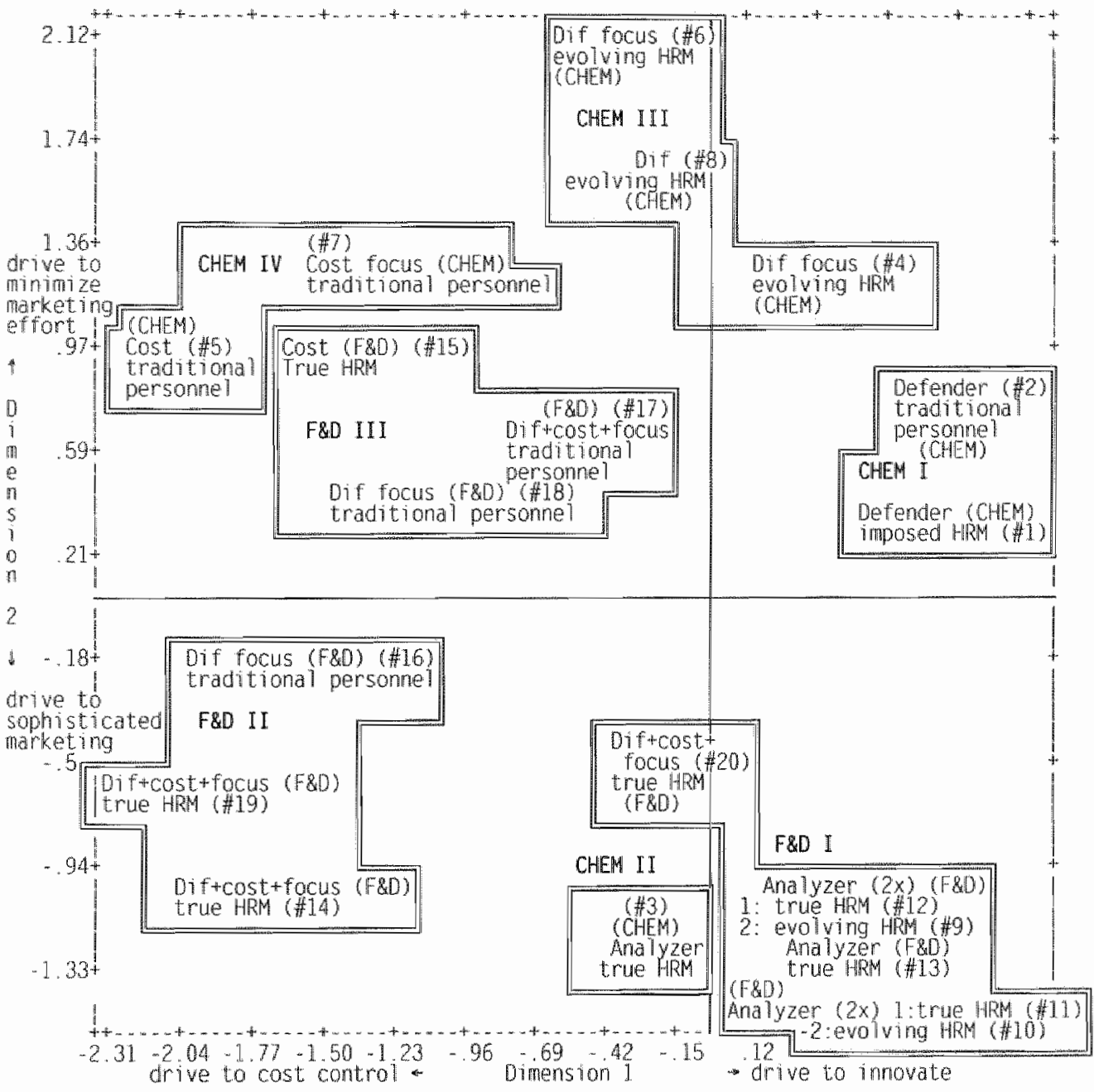

Figure 5.2: Food \& drink and chemical clusters labeled with HRM strategy-generic strategy pair 


\begin{tabular}{|c|c|}
\hline Chuster & HAM strategy generic strategies combinations \\
\hline 1 & $\begin{array}{l}\text { * company } 20 \text { with a combination strategy of cost leadership. differentiation and } \\
\text { focus and a true HRM strategy } \\
\text { three analyzers - companies } 11,12 \text { and } 13 \text { - with a true HAM strategy } \\
\text { * two analyzers - companies } 9 \text { and } 10 \text { - with an ewolving HRM strategy }\end{array}$ \\
\hline$\|$ & $\begin{array}{l}\text { *ompamies } 14 \text { and } 19 \text { with a combination strategw of cost leadership. } \\
\text { differentiation and focus and a true HRM strategy } \\
\text { * } \\
\text { mane differentiation focus strategy - company } 16 \text { - with traditional personnel } \\
\text { mant }\end{array}$ \\
\hline III & $\begin{array}{l}\text { * one cost leadlership strategy - compamy } 15 \text { - with a true HRM strategy } \\
\text { * company } 17 \text { with a combination strategy and traditional personnel management } \\
\text { *ne differentiation focus strategy-company } 18 \text { - with traditional personnel } \\
\text { management }\end{array}$ \\
\hline
\end{tabular}

Table 5.13: Three food \& drink clusters labeled by their HRM strategy-generic strategy combinations

Food \& drink cluster II contains two companies - 14 and 19 - with combination strategies of cost leadership, differentiation and focus that employ 'true' HRM strategies. Although this is consistent with their score on the environmental dimension 'drive to sophisticated marketing', it is still remarkable that their extreme score on the environmental dimension "drive to cast contral' seems to have so little impact on the control approach taken toward personnel. Company 16 employing a differentiation focus strategy in this cluster remains in a peculiar position, since - as was discussed in Chapter 3 - to follow such a generic strategy in this type of environment is almost impossible. The interpretation was then put forward that this firm implemented a different strategy than formally stated. The HRM profile supports this interpretation, since the traditional personnel strategy, centralized and not integrated with the generic strategy, fits well with the environmental conditions of a strong drive to cost control and only a very small drive to sophisticated marketing. Furthermore, the results in Chapter 4 confirmed this suspicion. Without implementing another generic strategy, this firm would suffer from inferior performance as then a mismatch between the competitive environment, the generic strategy and the type of personnel policy would frustrate its functioning.

Finally, there are three firms located in food \& drink clluster III. Although the two firms that practice traditional personnel management - companies 17 and 18 - possess personnel policies consistent with the environment they operate in, this is not consistent with their strategies pursued. In Chapter 3 it was concluded that their strategies do not match environmental conditions. The notion developed in Chapter 4 , that these firms may be in transition to food \& drink cluster I, is not (yet) supported by their personnel policies. The state of flux that these firms apparently reveal, should result in inferior performance. The cost leadership firm - number 15 - also takes a special position in this cluster. Theoretically, an imposed HRM strategy would be expected, since this would be in line with the organizational control requirements of 
a cost leadership strategy. The only possible explanation for this misfit is that the lowest-cost condition and the associated centralized mode of cantrol, is relaxed regarding HRM. However, this implies that their competitive strategy based on gaining a competitive advantage through lowest cost will suffer. In this case, it is doubtful whether the competitive position of the company will actually deteriorate, since the company operates in a market that is characterized by a duopoly situation heavily regulated by the national government and the EC. According to Hrebiniak and Joyce (1985), discussed in Chapter 1 , this organization thus operates in an environment where both environmental selection and organizational choice are low. On the question posed in Chapter 3 , whether these three companies belong to one strategic group, the answer can be a definite no. The cost leadership company more likely forms a graup on its own.

\section{Chemicals}

The first notable difference between the food \& drink and the chemical industry, when examining Figure 5.2, is that the adoption of 'true' HRM strategies only occurs in one company in our chemical industry sample. Furthermore, environmental dimension 1 does generally discriminate between the adoption of HRM approaches, while for dimension 2 this is not the case. Which HRM strategy - generic strategy pairs existi in the chemical industry is presented in Table 5.14.

\begin{tabular}{|c|c|}
\hline Chuster & HRM strategy-generic strategy combinations \\
\hline 1 & $\begin{array}{l}\text { * ane defender - company } 2 \text { - with traditional persannel management } \\
\text { * one defender - company } 1 \text { - with an imposed HAM stratggy }\end{array}$ \\
\hline$\|$ & one analyzer - company 3 - with true HRM \\
\hline$\| 11$ & $\begin{array}{l}\text { two differentiation focus strategies - companies } 4 \text { and } 6 \text { - with an evolving } \\
\text { HAM strategy } \\
\text { one differentiation strategy - company } 8 \text { - with an evolving HRM strategy }\end{array}$ \\
\hline IW & $\begin{array}{l}\text { *ne cost leadership strategy - company } 5 \text { - with traditional personnel } \\
\text { management } \\
\text { one cost facus strategy - company } 7 \text { - with traditional personnel management }\end{array}$ \\
\hline
\end{tabular}

Table 5.14: Four chemical clusters labeled by their HRM strategy-generic strategy combinations

The two chemical companies in cluster I following a defender strategy - companies 1 and 2 - still reflect a peculiar combination in this type of environment. The defender with traditional personnel management seems most out of place. Although its HRM strategy-generic strategy combination as such is consistent, it is unlikely to successfully compete with such a combination in an environment with such a strong drive to innovate. A possible explanation is that the environment changed but the company has not (yet) found a way to respond to these changes. The idea proposed 
in Chapters 3 and 4 that this firm is a potential reactor could indeed be true. The other defender in this cluster with an 'imposed" HRM strategy could have been caught in the same situation, with the exception that this firm induced changes to adapt to the needs of a drive to innovate. Whether the performance of these companies indeed suffers, depends on how long ago the environment changed and how fast they are adapting to the changing environment.

Company 3 in chemical cluster 11 with an analyzer strategy employs an HRM strategy that is consistent with their generic strategv and competitive environment.

Cherrical cluster III contains three firms all following an "evolving" HRM strategy. The fact that their approach to personnel is decentralized is consistent with their differentiation (focus) strategies. Furthermore this HRM profile is cansistent with the environment that they are facing. Two of these organizations

- companies 6 and 8 - operate in an environment with a modest drive to cost control and one organization - company 4 - in an environment with a drive to innovate.

Finally, the two companies in chemical cluster IV pursue a cost leadership and cost focus strategy, respectively. Both firms practice traditional personnel management, as would be expected based on the strategy and environmental conditions.

\subsection{Conclusion}

The question that is the running thread in this chapter is: is human resource management (HRM) used as a management tool to support the different strategies in the different competitive environments? To be able to answer this question, two types of relationships were discussed above. First, the relationship between different components of HRM and features of the Dutch and British business system is analyzed so as to gain an understanding of whether business system features stimulate or dampen the adoption of HRM policies in both countries. It is argued that a societal effect on the implementation of HRM components is substantial mainly in the categories of recruitment and selection on the one hand and performance appraisal and compensation on the other. Since this societal effect diversifies the meaning of what HRM comprises in both countries, comparisons on whether a shift from traditional personnel management to HRM has accurred in the Netherlands and Great Britain become difficult. Therefore, a level of analysis that is less affected by a societal effect, is needed. So, to examine whether HRM is used as a management tool to support the generic strategy pursued, not the individual components of HRM are analyzed but the overall personnel or HRM strategy. Based on the level of strategic integration and decentralization of personnel policies, four types of HRM strategies emerge: a "true" HAM strategy that is integrated with the generic strategy pursued and decentralized to a lower level in the organization; an 'imposed' HRM strategy that is also integrated 
with the generic strategy pursued but implemented in a centralized manner; an 'evolving' HRM strategy, where personnel policies are developed at a decentralized level without being integrated with the generic strategy pursued; and, finally, a traditional personnel strategy without strategic integration and decentralization.

This brings us to the second type of relationship studied: the linkage between the types of HRM strategies, the generic strategies and the competitive environment. When the clusters in the food \& drink and chemical industry of Chapter 3 are examined, coherent enviromment - HRM strategy - generic strategy combinations indeed prevail. In these cases, it is assumed that the HRM strategy supports the generic strategy chosen, so that the question at the beginning of this section can be answered positively. The firms in the sample that employ any of the three HRM strategies are also expected to outperform the companies employing a traditional personnel strategy, even when a fit exists. However, also incoherent types can be distinguished of which three operate in the food \& drink industry and two in the chemical industry. These companies pursue potential reactor or 'stuck in the middle' strategies. This notion is supported by the findings in Chapters 3 and 4 . Their performance is therefore expected to be worse than the firms where a fit is indeed present.

The analysis in this chapter, however, also leaves important aspects of HRM strategies uncovered. Although these, unfortunately, cannot be addressed due to lack of (comparable) data, they are summarized below to guide future research.

1. One of the most serious limitations of the analysis in this chapter is that in discussing the relationship between HRM and generic strategies, no information is available on the actual implementation of HRM components.

It is assumed that when, for example, strategic integration and decentralization exist, this is reflected in how the HRM components are employed. This, of course, does not necessarily have to be the case. Figure 5.3 presents a summary of the relationship between HRM profiles and generic strategies proposed in this chapter. The likelihood of the combinations lindicated by $X$ in the figurel is based on rather general assumptions of which dominant form of control associated with each of the generic strategies corresponds with the HRM profiles. So, the question whether the implementation of the HRM components regarding recruitment and selection (R\&S), performance appraisal and compensation ( $\mathrm{F} \& \mathrm{C}$ ) and training and development (T\&D) differs over the different HRM strategy types on the one hand and the generic strategies on the other (so whether the content of the boxes marked with $X$ differs), still needs to be addressed in both countries. It would be interesting to see how much the content of HRM strategies actually differs over generic strategies when a societal effect is taken into account.

2. The second limitation is that the third feature that defines HRM - the integration of the different components - is not studied. Because even when the overall 


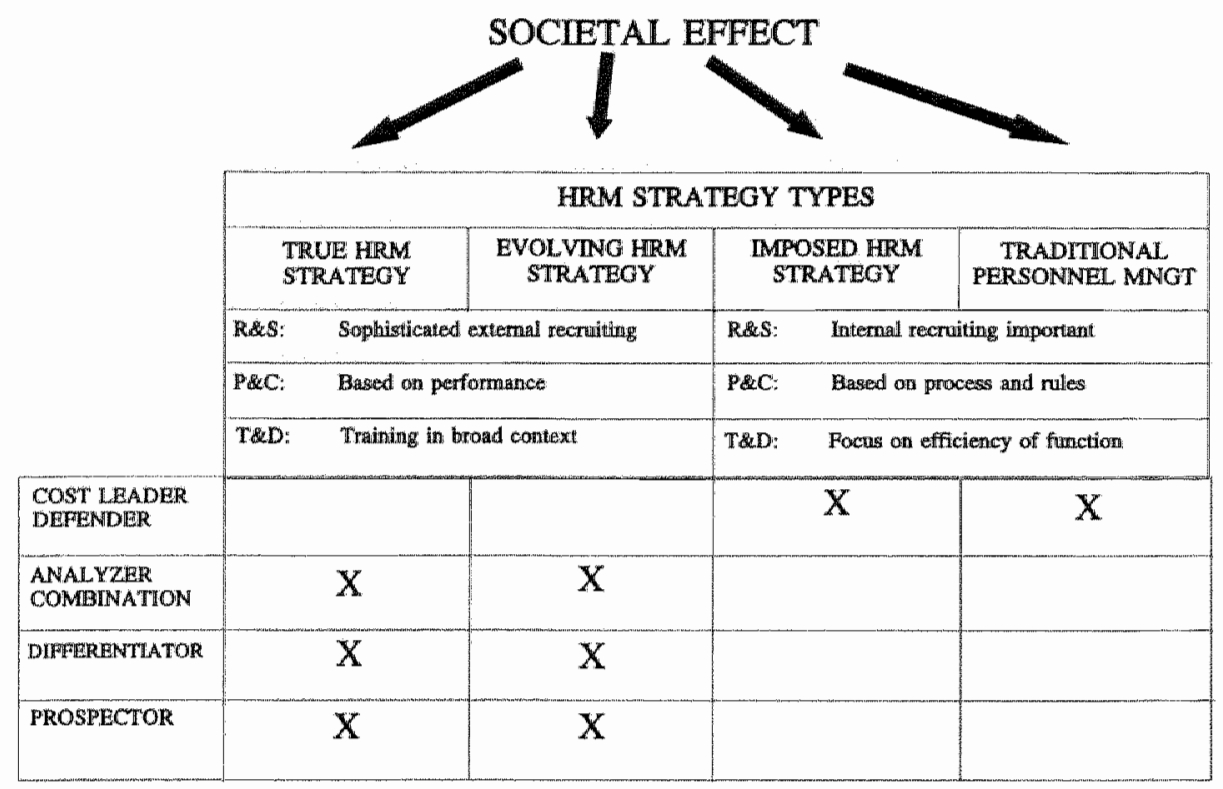

Figure 5.3: Relationship between generic strategies and HRM strategy types

HRM strategy is integrated with the generic strategy pursued and decentralized to lower levels within the organization, this does not automatically imply that the HRM components are employed in an integrated way too. 


\title{
CHAPTER 6
}

\section{THE RELATIONSHIP BETWEEN THE TECHNOLOGICAL SETTING,}

\author{
WORK ORGANIZATION AND HUMAN RESOURCE MANAGEMENT
}

The previous two chapters discussed the relationship between the technological setting, the competitive environment and generic strategies on the one hand (Chapter 4) and the relationship between human resource management, the competitive environment and generic strategies on the other (Chapter 5). This chapter examines the linkage between the specific strategies regarding manufacturing technology and human resource management. Since the manufacturing technology and personnel are both production factors that are a Siamese twin (Hetebrij \& Jonker, 1992) and production technology can thus not be viewed separate from the social structure of the organization (Gillespie and Mileti, 1977; and Buitendam, 1987), the main question guiding this chapter is how certain technological settings relate to the functioning of personnel. Especially the introduction of advanced manufacturing technologies has changed the nature of the contributions expected from employees and thus requires different methods to manage and motivate persomnel (Snell \& Dean, 1994). Furthermore, evidence suggests that the success of the implementation of advanced manufacturing technologies is largely dependent upon human resource issues (Ettlie, 1986; and Adler, 1988).

Section 6.1 provides a brief overview of the existing literature on the relationship between technology and the management of personnel. Section 6.2 examines empirically if and how in our sample the implementation of advanced manufacturing technologies changes the production environment in large batch and mass production on the one hand and in continuous process production on the other. In Section 6.3 the existing combinations of production technology types and human resource policies are analyzed. Although the analysis is complicated by lack of specific data, support is provided for the hypothesis that in the majority of companies compatible technology-HRM combinations prevail. Section 6.4, finally, presents a conclusion. The relationships discussed in this chapter are summarized in Figure 6. 1. 


\section{COMPETITIVE \\ ENVIRONMENT}

\section{TECHNOLOGICAL SETTING (6.2) \\ 1 \\ WORK ORGANIZATION \\ $\&$ \\ HUMAN RESOURCE \\ MANAGEMENT (6.3)}

\section{GENERIC STRATEGIES}

Figure 6.1: The relationship between the technological setting and human resource management

6.1 The relationship between production technology and the management of personnel: a brief overview of existing literature

The relationship between production technology and the management of personnel is closely linked to how production technology and the structure of the (work) organization relate (Sorge, 1989; Benders, 1992). Although the specific relationship of technology to structure was investigated by many authors (e.g. Hickson, Pugh \& Pheysey, 1969; and Blau, McHugh Falbe \& Tracy, 1976), only few consistent results appeared (Gerwin, 1981). It is beyond the scope of this section however to extensively summarize this debate (for an overview: Gillespie \& Mileti, 1977: Gerwin, 1981; and Fry, 1982). Therefore, only two illustrative examples of technology-structure research will be presented here.

One of the first to investigate this relationship was Woodward (1965). whose categorization of production systems was also used to characterize the manufacturing technologies of the companies in our sample (see also Chapter 4 ). She identified three broad categories of production systems - unit and small batch production, large batch and mass production and continuous process production that represent a scale of increasing predictability and controllability. Unit and small batch production is least predictable and controllable, while continuous process production is most predictable and controllable. Mass and large batch production is situated in between. This scale was associated with the following structural characteristics in Woodward's sample: as one moves from unit and small batch production to continuous process production, the number of staff specialties. 
averall formalization and formalization of personnel procedures, and a chief's executive span of control all increase, while the subordinate ratio first increases and then decreases. This is comparable to the earlier work on technology-structure relationships by Burns and Stalker (1961) who distinguished mechanistic from organic organizations. Organic organizations are characterized by high complexity, low formalization, low centralization and a technology with low predictability, low controllability and high variety. Mechanistic organizations exhibit low complexity, high formalization and centralization and a technology that is characterized by high predictability, high controllability and low variety. So according to this reasoning, organizations employing unit and small batch production operate in organic structures, while large batch and mass production as well as continuous process production firms exhibit features of a mechanistic organization.

The relative simplicity of the technology-structure relationships described above has to be questioned, however, in the light of the developments in manufacturing technologies that have taken place in the last decades. As was discussed in Chapter 4, the introduction of automation methods like, for example. Computer Aided Manufacturing (CAM), Computer Aided Process Planning (CAPP) or Material Requirement Planning (MRP) has altered the traditional Woodward production types in the sense that combinations between the three types become possible (Adler, 1988; and Nemetz \& Fry, 1988). This also implies that the relationship of manufacturing technology with structure becomes more complex. Since, when the introduction of automation methods enhances the flexibility in each of the three production types by making production of a larger variety of products on the same equipment feasible, the predictability and controllability of large batch and mass production as well as continuous process production is likely to decrease. This results in increasing complexity, interdependence and uncertainty in the production environment. The question of interest in the HRM context now becomes twofold: (i) Does the increased complexity, interdependence and uncertainty in the production enviromment affect the organization of work?; and (ii) if it does, how does this affect the management of personnel? Both questions will be subsequently discussed.

The increasing complexity, interdependence and uncertainty in the production environment that results from the implementation of advanced manufacturing technologies can mainly be attributed to a further integration of the different parts of the production process and an increase in product variability. When product variability increases faster than the volume of output, one would expect work flow continuity and rigidity of differentiation to decrease (Sorge, 1989). The responsibilities of the employees are thus extended: their tasks shift from routine and repetitive to responsive and craft like and the associated behavior that is expected should change from standardized to adaptive (Nemetz \& Fry, 1988). Furthermore, the enlarged integration of the production process not only 
increases the number of aspects of the physical production process that have to be understood, but also requires an understanding of the information flows that drive the production process. The identification and solving of problems have therefore become more complex (Adler, 1988). This increase in the diversity and complexity of tasks going along with the introduction of advanced manufacturing technologies has also emerged from case study research in continuous and discontinuous process industries in France (Cavestro, 1989). In addition to the fact that the task content becomes more complex, behavioral skills also deserve more attention. In order to manage the integration of different parts of the production process, interfunctional cooperation and team work gain importance (Buitendam, 1987; and Dumering, Safayeni \& Purdy, 19931. In general, it appears that the breadth as well as the depth of jobs is 'upgraded" through requiring higher technical, conceptual, analytical and problem-solving skills (Hayes, Wheelwright \& Clark 1988; and Snell \& Dean, 1992).

The fact that the implementation of advanced manufacturing technologies alters the contribution expected from employees, does not automatically imply that organizations change their structures accordingly. The relationship between advanced manufacturing technology and jab design is moderated by sources of organizational inertia (Child, Ganter \& Kieser, 1987; and Kelley, 1989). Dean and Sinell (1991) found that size, performance and dependency on a parent corporation are three factors that influence the technology-job design relationship. These findings indicate that it is a combination of technical, organizational and environmental factors that influences how the organization of work is configured. This implies that besides discussing the presumed "ideal" configuration between advanced manufacturing technology and job design, it is equally important to analyze the implications that advanced manufacturing technologies may have on other existing structural arrangements. To provide an illustration, the two extreme forms of mechanistic and organic organizations are subsequently discussed.

Organizations with mechanistic structures have more difficulties dealing with the implementation of advanced manufacturing technologies than organizations with organic structures (Zammuto and O'Connor, 1992). In a mechanistic structure, organizations emphasize a control-oriented approach aimed at efficiency to deal with the increased uncertainty. A control-oriented approach implies centralization of decision making and problem solving resulting in simplified, highly specialized production jobs limited to the physical execution of the work. The manufacturing process is viewed as a set of well-defined tasks that can be designed in an optimal manner by higher level staff or management. So, labor is a variable cost that can be reduced by creating tasks that are as specific - and thus efficient - as possible. When uncertailnty increases, more control is exercised. Although this approach may result in increased productivity due to less direct labor and training cost, the 'de-skilling' of jobs and the centralized structure prohibits 
organizational llearning - making successful implementation of advanced manufacturing technolagies, and thus flexibility, very difficult (Hayes, Wheelwright \& Clark, 1988; and Zammuto \& O'Connor, 1992).

This control-oriented approach to the management of personnel resembles traditional personnel management and, in a sense due to its centralized nature. imposed HRM (see also Chapter 5). Because labor is unskilled or semiskilled. recruitment and selection practices will be relatively simple and informal, training is limited and performance appraisal is aimed at detecting deviations from the standard (Snell \& Dean, 1992). Because of the high level of specialization, jobs are narrowly defined and rewarded by individual incentives, hourly wages and seniority pay (Snell \& Dean, 1994). The paradox of this approach, however, is that through the implementation of advanced manufacturing technologies employees get more access to information on the production process, but they are prohibited to act upon it. Not only will this undermine the morale of the workers, but it will also constrain the full potential of advanced manufacturing technologies (Hayes, Wheelwright \& Clark, 1988).

Organic structures on the other hand, are flexibility oriented. The manufacturing process in these organizations is seen as complex and changing. The increased complexity, interdependence and uncertainty associated with the implementation of advanced manufacturing technologies is therefore dealt with by decentralization of expertise and decision making. Management seeks to enhance the skills of employees at a decentralized level, implying the availability of multiskilled workers in semi-professional positions. Because employees need to use their skills innovatively, organizational learning is enhanced and the flexibility benefits of advanced manufacturing technologies are easier to obtain (Hayes, Wheelwright \& Clark, 1988; Dean, Yoon \& Susman, 1992; and Zammuto \& O'Connor, 1992). Disadvantages however are higher training costs and higher wages paid to the multi-skilled workers.

The management of personnel in organic structures will closely resemble a true HRM approach and, due to its decentralized nature, evolving HRM (see also Chapter 5). Because employees perform "knowledge work" recruitment procedures are more sophisticated, training is more comprehensive and performance appraisal is geared toward improvement of the functioning of employees (Snell \& Dean, 1992). Because jobs are defined more broadly and team work is important, employees tend to be rewarded by group as well as individual incentives, salary and seniority based pay (Snell \& Dean, 1994). The phenomena that are associated with mechanistic and organic approaches to advanced manufacturing technologies are similar to two effects discussed by Child (1987) and Sorge, Hartmamn. Warner \& Nicholas (1983). Child (1987) discusses a strategy of job degradation or even job elimination - which would fit a mechanistic perspective - as opposed to a strategy of polyvalence with the removal of job demarcation and job enrichment programs - 
which fits an organic approach. Sorge, Hartmann, Warner \& Nicholas (1983) distinguish between companies that employ advanced manufacturing technologies to reinforce the control of personnel through polarization and differentiation of functions (mechanistic) and companies that utilize advanced manufacturing technologies to extend the responsibilities of the production workers through depolarization and integration (organic).

There are however some problems with this line of reasoning. Firstly, these two approaches to the management of personnel represent extremes on a continuum. The relationship between manufacturing technology and the management of personnel is too complex to simply conclude that traditional manufacturing is associated with traditional personnel management, while advanced manufacturing technologies are associated with true HRM. As was discussed in Chapter 4 and 5 , there are different gradations in the adoption of advanced manufacturing technologies as well as in HRM practices. Furthermore, the direction of the relationship between the management of personnel and the successful implementation of advanced manufacturing technologies is not clear. Because of the existence of organizational inertia, it is possible that organizations either implemented advanced manufacturing technologies in a mechanistic structure and were unable to meet the changed HRM requirements or had already invested in a HRM approach to personnel and are thus more likely to adopt advanced manufacturing technologies (Snell \& Dean, 1992).

Because of the different gradations in the level of adoption of advanced manufacturing technologies as well as HRM policies and the difficulty in determining the direction of the relationship, an overview of possible combinations is presented in Table 6.1. The different types of production and HRM policies are explained in Chapters 4 and 5, respectively. Table 6.1, however, is built on three assumptions that need to be made explicit. First, the HRM policy of the company does not apply to the production function alone but to the entire organization. So, production is just one of the functional areas that relate to the chosen HRM policy. This might explain the existence of a true, evolving or imposed HRM approach when just modest implementation of advanced manufacturing technologies has taken place. Second, the content of the four HRM policies - in terms of specific HRM practices - is not known. As was discussed in Chapter 5, the four HRM policies are categorized on the basis of the level of centralization and decentralization on the one hand and the level of strategic integration on the other. This explains the lack of differentiation in HRM policies for the categories of intermediate and extended implementation of advanced manufacturing technologies. Finally, it is assumed that organizations only change existing practices when they perceive a need for change. So, to obtain a match between the HRM policy pursued and the advanced production technology implemented the production manager as well as the HRM manager have to perceive similar changes 


\begin{tabular}{|c|c|c|c|}
\hline & $\begin{array}{l}\text { Modest implamentation of new } \\
\text { manufacturing technologies. } \\
\text { - modified large batch and } \\
\text { mass production } \\
\text { - automated planning in } \\
\text { continuous process production } \\
\text { - automated continuous } \\
\text { process production } \\
\text { - automated design in } \\
\text { continuous process production }\end{array}$ & $\begin{array}{l}\text { Mntermediate } \\
\text { mplementation of new } \\
\text { matufacturing } \\
\text { technologies: } \\
\text { - automated large } \\
\text { batch and mass } \\
\text { production } \\
\text { - flexible continuous } \\
\text { process production }\end{array}$ & $\begin{array}{l}\text { Extended } \\
\text { mplementation of new } \\
\text { manufacturing } \\
\text { technologies: } \\
\text { - Hexible large batch } \\
\text { and mass production } \\
\text { - innovative large batch } \\
\text { and mass production }\end{array}$ \\
\hline True HRM & $\begin{array}{l}\text { HRM can create a context for } \\
\text { more technological chang }\end{array}$ & $\begin{array}{l}\text { "Ideal situation where } \\
\text { the management of } \\
\text { personnel and the } \\
\text { production } \\
\text { environment reinforce } \\
\text { each other to gain } \\
\text { fllexibility benefits }\end{array}$ & $\begin{array}{l}\text { "Ideal" situation where } \\
\text { the management of } \\
\text { personnel and the } \\
\text { production } \\
\text { environment reinforce } \\
\text { each other to gain } \\
\text { flexibility benefits }\end{array}$ \\
\hline $\begin{array}{l}\text { Evoluing } \\
\text { HRM }\end{array}$ & $\begin{array}{l}\text { Although HRM can create a } \\
\text { contex for more technological } \\
\text { change, a risk exists that top } \\
\text { managenent interferes when } \\
\text { HAM deviates from strategy }\end{array}$ & $\begin{array}{l}\text { Although management } \\
\text { off personnel and the } \\
\text { production } \\
\text { environment reintorce } \\
\text { each other, a risk } \\
\text { exists that top } \\
\text { management interferes } \\
\text { when HRM deviates } \\
\text { from strategy }\end{array}$ & $\begin{array}{l}\text { Although management } \\
\text { of persomnel and the } \\
\text { production } \\
\text { environment reinforce } \\
\text { each other, a risk } \\
\text { exists that top } \\
\text { management interferes } \\
\text { when HIR deviates } \\
\text { from strategy }\end{array}$ \\
\hline $\begin{array}{l}\text { Imposed } \\
\text { HRM }\end{array}$ & $\begin{array}{l}\text { Although HAM can create a } \\
\text { context for more technological } \\
\text { change, a risk exists that (i) } \\
\text { demands of lower units are not } \\
\text { taken into account and (ili the } \\
\text { approach takes on mechanistic } \\
\text { features }\end{array}$ & $\begin{array}{l}\text { Although management } \\
\text { of personnel and the } \\
\text { production } \\
\text { environment could } \\
\text { reinforce each other, a } \\
\text { risk exists that (ii) } \\
\text { demands of lower } \\
\text { units are not taken } \\
\text { into account and hil } \\
\text { the approach takes on } \\
\text { mechanistic features }\end{array}$ & $\begin{array}{l}\text { Although mamagement } \\
\text { of parsonnel and the } \\
\text { production } \\
\text { environment could } \\
\text { reinforce each other, a } \\
\text { risk exists that lil } \\
\text { demands of lower units } \\
\text { are not taken into } \\
\text { account and (ii) the } \\
\text { approach takes on } \\
\text { mechanistic features }\end{array}$ \\
\hline $\begin{array}{l}\text { Traditional } \\
\text { personner } \\
\text { management }\end{array}$ & $\begin{array}{l}\text { Fersonnel management } \\
\text { reinforces emphasis on } \\
\text { effictency and productivity }\end{array}$ & $\begin{array}{l}\text { Personnel management } \\
\text { anhibuts the derivation } \\
\text { of flexbility benefits }\end{array}$ & $\begin{array}{l}\text { Personmel management } \\
\text { infibits the derivation } \\
\text { of flextbilly benetits }\end{array}$ \\
\hline
\end{tabular}

\section{Table 6.1: Propositions on the relationship between technology and HRM}

in the production environment. In the "ideal" situation this would imply that cooperation between both managers has taken place, either by means of integrating both production as well as HRM policies with strategy - as would be the case in true HRM or imposed HRM - or through decentralization HRM policies which is reflected in true HRM as well as evolving HRM. Some risk, however, remains with the impased or evalving HRM policies. When personnel management is centralized, as is the case in imposed HRM, the changes in the production environment could just be perceived differently at the higher level resulting in other changes than required at the lower production levell. Because of the centralized nature of imposed HRM the approach could become mechanistic, thereby blurring the boundaries between imposed HRM and traditional personnel management. In 
the case of evolving HRM, the necessary changes might be perceived and induced at a decentralized level, but not approved by centralized management when they deviate from the strategy pursued.

The analysis of the technollogy-structure relationship in our sample comes in two steps. First, the impact of the introduction of advanced manufacturing technologies on the production environment is examined. This was touched upon in Chapter 4 , but is discussed in more detail in Section 6.2. Section 6.3 then analyzes whether the HRM policy chosen is in conflict with or reinforces the production system that is implemented.

\subsection{The impact of advanced manufacturing technology on the production environment}

To determine how advanced manufacturing technologies influence the production environment, two aspects of automation are important. First, the extent to which the design, manufacturing or planning function is automated and, second, which specific automation methods are used.

It can be concluded from the literature overview in Section 6.1 that an increase in the number of implemented advanced manufacturing technologies results in greater complexity of the production environment. How the number of advanced manufacturing technologies is related to the perception of developments in the production environment by the companies interviewed is presented in Table 6.2 (see Appendix B for the interview schedule on this topic). Because of the differences that were established in Chapter 4 between largle and mass production on the one hand and continuous process production on the other, each production method is exanined separately using Spearman rank order correlation.

Three developments become apparent from Table 6.2. First, the proposed relationship between the number of advanced manufacturing technologies that are adopted and the complexity of the production environment gains some, though limited, support from our data. The relatively limited number of significant correlations could either be due to a simply less increasing complexity than is expected or to the fact that companies implemented the advanced manufacturing technologies some time ago and are now accustomed to an increased level of complexity. Therefore, they perceived no increase in complexity at the time the questions were asked. Unfortunately, however, no data are available on the time of implementation. Second, the adwanced manufacturing technologies studied here have a larger impact on the production environment of companies employing large batch and mass production than those employing continuous process production. This might be due to the fact that three of the advanced manufacturing technologies - the use of CNC machines, robots and FMS - are hardly suitable for 
continuous process production. The extent of automation in terms of the advanced manufacturing technologies we studied, is therefore larger in large batch and mass production than in continuous process production.

\begin{tabular}{|c|c|c|c|}
\hline & & \multicolumn{2}{|c|}{$\begin{array}{l}\text { Number of advanced } \\
\text { manufacturing technologies } \\
\text { that are implemented } \\
\text { (wariation from } 1 \text { to } 9 \text { ) }\end{array}$} \\
\hline & & $\begin{array}{l}\text { Large batch } \\
\text { and mass. } \\
\text { production }\end{array}$ & $\begin{array}{l}\text { Continuous } \\
\text { process } \\
\text { production }\end{array}$ \\
\hline 1. & Increase in number of different products & -0.2906 & 0.0671 \\
\hline 2. & Increase in variety from the standard & -0.1259 & 0.3785 \\
\hline 3. & Products become more standardized & -0.1347 & 0.3605 \\
\hline 4 & $\begin{array}{l}\text { The time between the initial idea for a new product and } \\
\text { when it enters production increases }\end{array}$ & 0.3669 & -0.2168 \\
\hline 5 & Decirease in inventory of work-in-process and final products & $0.4784^{*}$ & -0.2119 \\
\hline 6. & Increase in batch size & $0.6200^{* \prime \prime}$ & -0.0686 \\
\hline 7. & Increasing integration between produlction stages & $0.5303^{\circ}$ & 0.0592 \\
\hline B. & Increase in people involved in design and development & .0 .0885 & $0.6225^{\prime \prime}$ \\
\hline 9. & Increase in people involved in production planning & -0.0361 & 0.2014 \\
\hline 110 & $\begin{array}{l}\text { Management of materials and worlk-in-process is } \\
\text { decentralized to work stations }\end{array}$ & 0.4151 & 0.1734 \\
\hline 11 & $\begin{array}{l}\text { Set up rime for production decreases and the plant is more } \\
\text { intensively used }\end{array}$ & $\cdot$ & . \\
\hline 12. & Increase in specialization of skills & 0.2429 & $0.6624^{4 *}$ \\
\hline 13. & Increase in subcomuracting & -0.3 .472 & -0.2649 \\
\hline
\end{tabular}

significant at $p<0.1$

". significant at $p<0.05$

** a coefficient cannot be computed

Table 6.2: Spearman rank order correlation coefficients of the number of automation methods implemented and developments in the production environment

Third, the correlation coefficient between the extent of automation and a more intensive use of the plant could not be computed. All the companies, independent of whether they did or did not implement advanced manufacturing technologies, perceived their plants as being more intensively used (see Appendix $E$ for an overview of the mean scores companies obtained on each of the development statements). So the drive to produce as efficiently as possible - in the sense of a 
maximum utilization of capital - is present in all the companies interviewed.

In large batch and mass production significant correlations exist between the extent of automation and a decrease in inventories of work-in-process and final products $(p<0.1)$, an increase in batch size $(p<0.05)$ and increasing integration between production stages $(p<0.1)$. These developments indicate that advanced manufacturing technologies increase process rather than product flexibility (Jelinek \& Goldhar, 1984; Meredith, 1987; and Adler, 1988). The production process is utilized more efficiently making an increase in batch size and a decrease in inventories possible through increased integration. Although the relationship between the extent of automation and the decentralization of management of materials to work stations is not significant, it is worth noting that the positive association indicates that increasing process efficiency can come together with increasing discontinuity of the production process. The simultaneous increase in batch size and decrease in inventory can, however, only be combined with larger discontinuity because product flexibility - in terms of a larger number of production and design variants - is not directly affected. When product flexibility also increases, the relationship becomes substantially more complicated (Sorge, 1989).

In continuous process production significant correlations exist with only two developments in the production environment. The extent of automation in this production process is significantly correlated with an increase in the number of people involved in design and development compared to those working in production ( $p<0.05)$ and with an increasing specialization of skills (p $<0.05$. That process flexibility does not significantly increase when advanced manufacturing technologies are implemented is not surprising, since the nature of the production process makes this very difficult to achieve. Product flexibility. however, would be possible in a modest way resulting in an increase in the number of people involved in the design and development function. Since this could create entirely new functions and occupations, an increasing specialization of skills will be needed (Sorge, 1989).

However, not only the extent of automation alters the production environment, even the implementation of only one automation method in only one function can have a significant impact on the production environment. Whether the adoption of each of the advanced manufacturing technologies results in a significantly different perception of the production environment in continuous process production as well as in large batch and mass production, is tested using Mann Whitney tests. The results for large batch and mass production on the one hand and continuous process production on the other are presented in Table 6.3 and Table 6.4 respectively. 


\begin{tabular}{|c|c|c|}
\hline \multicolumn{2}{|c|}{$\begin{array}{l}\text { Advanced manufacturing } \\
\text { tronnology in large batch } \\
\text { and mass production }\end{array}$} & \multirow{2}{*}{ 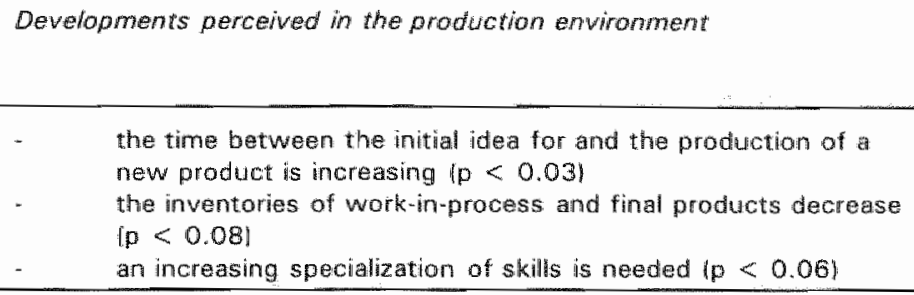 } \\
\hline 1. & $C A D$ & \\
\hline 2. & CAE & $\begin{array}{l}\text { batch size is increasing }(p<0.04) \\
\text { there is no increase in the number of people involved in design } \\
\text { and development compared to the number of production } \\
\text { workers }(p<0.09) \\
\text { the management of materials, components and work-process is } \\
\text { being decentralized to work stations }(p<0.09)\end{array}$ \\
\hline 3. & CAM & an increasing specialization of skills is needed $(p<0.06$ ) \\
\hline 4. & CAPP & $\begin{array}{l}\text { the number of different products produced does not incirease ip } \\
<0.071\end{array}$ \\
\hline 5. & CNC & $\begin{array}{l}\text { there is no increase in the time between the idea for a rew } \\
\text { product and when it enters praduction }(p<0.09)\end{array}$ \\
\hline 6 . & CPS & $\begin{array}{l}\text { batch size is increasing }(p<0.06) \\
\text { there is mo increase in the amount of work that is } \\
\text { subcontracted }(p<0.05)\end{array}$ \\
\hline 7. & FMS & $\begin{array}{l}\text { there are no significant differences in the perception of the } \\
\text { production environment between those compantes that did and } \\
\text { those that did not adopt FMS }\end{array}$ \\
\hline 8. & MRP & $\begin{array}{l}\text { the inventories of work-in-process and final products decrease } \\
(p<0.08) \\
\text { the stages of the production process are more closely } \\
\text { integrated ip }<0.05 \text { ) } \\
\text { there is ruo increase in the amount of work that is } \\
\text { subcontracted }(p<0.03)\end{array}$ \\
\hline 9 & Robotics & batch size is increasing $(\mathrm{p}<0.07$ ) \\
\hline
\end{tabular}

Table 6.3: Significantly different developments in the production environment of large batch and mass production when advanced manufacturing technologies are implemented

From Table 6.3 and 6.4 it can be concluded that also many of the individual automation methods can result in a different perception of the production environment. Furthermore, the difference between large batch and mass production on the one hand and in continuaus process production on the other remains apparent. For three of the automation methods - CAD, CAE and CAM - no significant difference in perception of the production environment occurred between those companies that did implement these technologies and those that did not. This could be due to either the fact that these methods were implemented some time ago so that no changes in the production environment are perceived anymore or the fact that the importance of these technologies to the entire production process is 
limited. Unfortunately, no data are available to explore this issue.

Each of these developments and their influence on the management of persannel is discussed in the course of Section 6.3.

\begin{tabular}{|c|c|c|}
\hline \multicolumn{2}{|c|}{$\begin{array}{l}\text { Advarnced manufacturing } \\
\text { technology in continuous } \\
\text { process production }\end{array}$} & Developments perceived in the production environment \\
\hline 1. & $C A D$ & $\begin{array}{l}\text { there are no significant differences in the perception of the } \\
\text { production enwironment between those companies that did and } \\
\text { those that did not adopt CAD }\end{array}$ \\
\hline 2 & $C A E$ & $\begin{array}{l}\text { there are no significant differences in the perception of the } \\
\text { production environment between those companies that did and } \\
\text { those that did not adopt CAE }\end{array}$ \\
\hline 3. & CAM & $\begin{array}{l}\text { there are no significant differences in the perception of the } \\
\text { production environment between these companies that did and } \\
\text { those that did not adopt CAM }\end{array}$ \\
\hline 4. & CAPP & $\begin{array}{l}\text { batch size is increasing }(p<0.1) \\
\text { the amount of work subcontracted increases }(p<0.09 \text { ) }\end{array}$ \\
\hline 5. & CNC & $\begin{array}{l}\text { there are no companies in continuous process production that } \\
\text { utilize CNC machines }\end{array}$ \\
\hline 6. & CuPS & $\begin{array}{l}\text { there is no increase in integration between the different phases } \\
\text { of production }(p<0.05)\end{array}$ \\
\hline 7 & FMS & $\begin{array}{l}\text { there are no companies in continuous process production that } \\
\text { utilize FMS }\end{array}$ \\
\hline 8. & MRP & $\begin{array}{l}\text { the number of people involved in the design and development } \\
\text { function is increasing compared to the number of production } \\
\text { workers }(p<0.04)\end{array}$ \\
\hline 9. & Mobotics & there are no robots used in continuous process production \\
\hline
\end{tabular}

Table 6.4: Significantly different developments in the production environment of continuous process production when advanced manufacturing technologies are implemented

\subsection{Advanced manufacturing technology and human resource management: opposing or reinforcing policies?}

To determine whether advanced manufacturing technologies and human resource management oppose or reinforce each other - again - the extent of automation as well as the individual automation methods are considered. The relationship of the extent of automation to HRM is examined first by means of Mann Whitney tests. The HRM categories were combined into centralized HRM - consisting of traditional personnel management and imposed HRM - on the one hand and decentralized HRM - consisting of true HRM and evolving HRM - on the other. Although decentralized HRM obtained a slightly higher mean ranking on the number of 
advanced technologies implemented 19.82 as opposed to 9.00 for centralized HRM), no significant differences appeared. Also when the HRM categories were combined into strategically integrated HRM - consisting of true HRM and imposed HRM - and HRM not integrated with strategy - consisting of evolving HRM and traditional personnel management - no significant differences appeared. The mean ranking on the number of advanced manufacturing technologies implemented is " however, again slightly higher for HRM integrated with strategy than for HRM not integrated with strategy $(10.38$ as opposed to 8.80$)$.

So since no general relationship between the advanced manufacturing technologies and the HRM categories can be detected, the technology-HRM combinations that are employed in each of the companies interviewed are summarized in Tables 6.5 and 6.6.

\begin{tabular}{|c|c|c|c|c|}
\hline & $\begin{array}{l}\text { Modified large } \\
\text { batch and mass } \\
\text { production }\end{array}$ & $\begin{array}{l}\text { Automated large } \\
\text { batch and mass } \\
\text { production }\end{array}$ & $\begin{array}{l}\text { Flexible large } \\
\text { batch and mass } \\
\text { production }\end{array}$ & $\begin{array}{l}\text { Innovative large } \\
\text { batch and mass } \\
\text { production }\end{array}$ \\
\hline True HAM & & & $\begin{array}{l}\text { Complany } 12 \\
\text { Comprany } 13\end{array}$ & $\begin{array}{l}\text { Company } 3 \\
\text { Company } 11\end{array}$ \\
\hline Evolving HRM & Company 4 & Company 9 & & Company 40 \\
\hline \multicolumn{5}{|l|}{ Imposed HRM } \\
\hline $\begin{array}{l}\text { Traditional personnel } \\
\text { management }\end{array}$ & Company 16 & Company 17 & Company 2 & \\
\hline
\end{tabular}

Table 6.5: Human resource management systems employed in different advanced large batch and mass manufacturing types

\begin{tabular}{|c|c|c|c|c|}
\hline & $\begin{array}{l}\text { Automated } \\
\text { planning in } \\
\text { continuous process } \\
\text { production }\end{array}$ & $\begin{array}{l}\text { Automated distign } \\
\text { in continuous } \\
\text { process production }\end{array}$ & $\begin{array}{l}\text { Automated } \\
\text { continuaus } \\
\text { process } \\
\text { production }\end{array}$ & $\begin{array}{l}\text { F/enible } \\
\text { continuous } \\
\text { process } \\
\text { production }\end{array}$ \\
\hline True HRM & Company 14 & Company 19 & & Company 15 \\
\hline Evolving MRM & & & Company 16 & \\
\hline monsed HRM & & & & Company 1 \\
\hline $\begin{array}{l}\text { Traditional personnel } \\
\text { management }\end{array}$ & & & Company 5 & $\begin{array}{l}\text { Compary } 47 \\
\text { Company } 18\end{array}$ \\
\hline
\end{tabular}

Table 6.6: Human resource management systems employed in different advanced continuous process manufacturing types 
Each of these combinations will be subsequently discussed using the results of Table 6.3 and Table 6.4. Although in general it is, of course, not appropriate to use Tables 6.3 and 6.4 - since these present significant differences at an aggregated production system level - for the analysis of the individual companies, it is deliberately done here. Namely, Tables 6.3 and 6.4 describe how companies with large batch and mass production on the one hand and continuous process production on the other, on average perceive changes in the production environment when advanced manufacturing technologies are implemented. So, for example, in large batch and mass production the implementation of CAM is in the majority of companies associated with an increasing specialization of skills (Table 6.3). At the company level of analysis, it is possible for an individual organization which implemented CAM to not perceive this increasing need for specialization of skills and therefore adapt - or not change - its HRM policy accordingly. In this case the company perceives its technology-HRM combination as consistent, but compared to competition it is not. Therefore, the aggregated results serve as an average standard, or benchmark, against which HRM policies are examined in the individual companies.

It should be noted that due to lack of data on the content of the HRM categories the discussion, unfortunately, can merely provide tentative suggestions on a potential HRM-technology fit. Furthermore country and/or industry differences are not specifically examined because (i) these were analyzed in Chapters 4 and 5 and (ii) the companies are studied at the individual level making more general suggestions on country and industry differences not feasible. The nationality and industry of each company will, however, still be indicated. As in the previous chapters the numbers of the companies correspond to a short company description in Appendix A.

\section{LARGE BATCH AND MASS PRODUCTION}

\section{Modified large batch and mass production}

Two companies are located in this category that both only use one automation method in production. One of these two companies has also implemented an automated planning system.

Company 16 - a Dutch food \& drink company - with traditional personnel management has automated parts of the production process through the use of CNC machines. The only development that is perceived significantly different when CNC machines are employed is that the time between the initial idea for a new product and when it is ready to enter into production remains constant or possibly decreases (Table 6.3). Although in itself the impact of this development on the management of personnel is limited, it could imply that parts of the production process become more efficient in the sense that the time needed to change the production process to manufacture a different product is reduced. The 


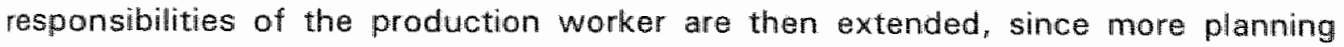
and programming takes place at the CNC machine directly (Sorge, 1989). The impact of CNC machines on the management of personnel in this case is thus limited to the production employees working with them. Since, however, personnel is managed in a traditional fashion fitting within a mechanistic appraach, the production workers' job is not expected to be altered significantly. The authority to change the programming or planning on the machines will be located at a higher level in the organization. Since, however, the main emphasis seems to be on efficiency rather than on flexibility, the present traditional personnel management system is not expected to constrain the functioning of the production process (yet).

Company 4 - a Dutch chemical company - practicing evolving HRM, implemented CNC machines in production in combination with MRP in the planning of materials. In addition to the development in the production environment associated with CNC machines, three other developments related to the use of MRP have to be taken into account. MRP is associated with decreasing inventories of work-in-process and final products, increasing integration of the stages of the production process and a reduction of work that is subcontracted. So. MRP is mainly concerned with process flexibility. The production environment becomes considerably more complex, though, than when just CNC machines are used, since the increased integration can only be achieved when the differentiation of functions becomes less rigid (Sorge, 1989). In other words, previously separate jobs are combined and possiblly even taken over by CNC machines. This implies an upgrading of the required qualifications of the employees, in the sense that their insight in the production process needs to be expanded to obtain the necessary integration. In an evolving HRM approach the possibility is created at a decentralized level to act upon the requirements of larger integration and to obtain the efficiency benefits of a CNC-MRP combination. MRP as a planning system alone cannot, of course, provide the integration.

\section{Automated large batch and mass production}

Two companies fit into this category. These automated parts of their production process through CNC, Robots or CPS, their planning of materials through MRP and their design of the production process through CAPP.

Company 17, a Dutch food \& drink company that uses traditional personnel management, has implemented all of the automation methods mentioned above. Table 6.3 indicates that it therefore faces a whole variety of developments in its production environment: the range of products does not increase (CAPP), but the batch size in which the existing products are produced has become larger (Robots and CPS). This can only be associated with more efficient production when inventories decrease (MRP) and the stages of the production process are further integrated (MRP). It seems that the production process becomes more continuous in the sense that economies of scale can be abtained as a result of the increased 
batch size and the further integration. Although it may seem that traditional personnel management would fit this production system with its emphasis on efficiency, it will fail to create the conditions in which integration between the stages of production is facilitated. When the potential for integration is not realized, efficiency benefits will be lost due to the building up of inventories. A true or evolving HRM approach in which the skills of the emplovees are enhanced and their responsibilities extended, would provide a better fit.

Company 9 - a British food \& drink company - has automated its production through the use of CNC, its planning system by MRP and its design of the production process with CAPP. This firm operates within an evolving HRM approach. Considering, again, the necessity to realize the integration potential provided by MRP and CAPP, an evolving HRM approach seems appropriate.

\section{Flexible large batch and mass production}

This category contains three companies that automated their production process in an integrated way through CAM, their design function with $C A D$ and/or CAE and their planning function with MRP. Two companies also automated the design of the production process with CAPP and two companies use CNC machines and CPS in addition to CAM.

Company 2 - a British chemical company - employs traditional personnel management as its human resource policy. Moreover, this firm automated production by using CAM, CNC and CPS, planning is automated using MRP and design through CAD. This company faces almost the same changes in the production environment as company 17, though the complexity is even larger because also CAD and CAM are used. The use of CAD and CNC machines results in a conflicting change pattern: the time it takes to enter a new product idea into production increases (CAD) as well as decreases (CNC). Furthermore, a need for an increasing specialization of skills is perceived (CAD and CAM). So, in this company the interesting combination occurs of a less rigid differentiation of functions due to increasing integration between the phases of production on the one hand and an increasing specialization of skills due to the creation of new work roles and occupations on the other (Sorge, 1989). Traditional personnel management will deal with this increased complexity by increasing control and thus providing more detailed job descriptions, procedures and regulations. It is very unlikely that within this personnel management system employees can be motivated, trained and retained to deal with such a complex and differentiated environment.

Company 12 - a British food \& drink company - adopted a true HRM policy and automated the production function through use of CAM, CNC and CPS, the design functions through CAD, CAE and CAPP and the planning function with MRP. The changes in the production environment closely resemble those facing company 2, though two ather developments are added: the number of people involved in design and development does not increase compared to the number of production 
workers (CAE) and the management of materials is decentralized to work stations (CAE). Especially the latter aspect is important, since this implies a substantial increase in the discontinuity of the production process while at the same time batch size is increased. Integration of the different phases of production now becomes crucial to decrease inventories (Sorge, 1989). So, although also in this company decreasing differentiation of functions is combined with increasing specialization of skills, the consequences of an inappropriate management of personnel will be far more severe. When integration is not achieved, efficiency benefits will be lost due to the increasing inventories building up between the discontinuous stages of production. A true HRM approach therefore is most likely to be able to prevent this. Furthermore, although no significant increase in production or design variants appeared yet, it could create the atmosphere in which not only efficiency but also flexibility benefits could be obtained.

Finally, company 13 - again a British food \& drink company - also pursues a true HRM policy and implemented CAM in production, CAD and CAPP in design and MRiP in planning. The changes in the production environment for this company can again be summarized as resulting in an extension of the responsibilities of production workers due to a less rigid differentiation and an increasing specialization of skills. True HRM should be able to create the environment in which employees can successfully deal with these changes.

\section{Innovative large batch and mass production}

This category holds three companies that automated their production in the most flexible way through at least FMS, integrated their design function through at least the use of CAD and their planning function with MRP.

Company 10 - a British food \& drink company - with an evolving HRM approach automated production through FMS and CPS, design through CAD and CAPP and planning through MRP. Surprisingly, no significantly different developments in the production enviranment were perceived by those companies that implemented FMS compared to those that did not. One explanation could be that since this is one of the most flexible - and thus advanced - production systems than can be employed, the companies implemented FMS in stages and/or some time ago causing them to perceive no changes in the production environment anwmore. This implies that they are already operating in a more complex environment. If the implementation off FMS just really does not cause any significant changes, the production environment is similar to the one that the companies in the category of flexible large batch and mass production. In either situation, evolving HRM seems suitable.

For company 11 - again a British food \& drink company that utilizes true HRM - a similar reasoning applies. True HRM also fits either scenario discussed above.

Company 3, nonetheless, is an interesting case. This British chemical 
company automated its production by means of CAM, FMS, CNC machines and Robots and its design function with CAD and CAPP. What is lacking here, though, is MRP (the automation of the planning function) that was associated with a perceived increase in integration of the production stages. So, here batch size increases (Robots). while inventories of work-in-progress and final products are perceived to decrease (CAD) without an increase in integration. Although CAD can contribute to a more efficient planning and programming of the production process (Sorge, 1989 ) and thus potentiallly to a decrease of inventories, no significant increase in integration results from the use of CAD $(p=0.2207)$. The only possible explanation is that the employees themselves provide a substantial part of the coordination between the production stages instead of an automated method. Whether this would be feasible in the longer run is questionable, even with true HRM.

\section{CONTINUOUS PROCESS PRODUCTION}

\section{Automated planning in continuous process production}

This category contains only one Dutch food \& drink company, company 14, that automated its planning process through MRP. The only change in the production environment associated with MRP is that the number of people involved in design and development increases compared to the number of production workers (Table $6.4)$. The meaning of this statement is, unfortunately, not completely clear: does it refer to the design and development of new products or to the design and development of the production process? When it relates to the design and development of new products, this development at first sight seems to be unrellated to MRP. However, it appears that the companies that implemented MRP also perceive, although not significantly, an increase in the number of products ( $\mathrm{p}=$ 0.1635 ) and an increase in the variety of production and design variants $(p=$ 0.1190 ). Since in continuous process production it is very unlikely that many people were involved in design and development of new products, a small increase in this number can already lead to a significant result. When, however, the statement refers to the design and development of the production process, it makes more sense. Since in continuous process production the production process itself is highly regulated and automated, there are no or just relatively few people directly involved with the production process itself. People working in the production function are mainly concerned with the design and maintenance of the system (Mintzberg. 1983). So, when an automated system for the planning of materials is introduced, this may lead to a further increase in the number of people involved in designing the process. The impact on the management of personnel in both cases, however, is limited to the possible creation of new functions in design and development. True HRM will certainly fit this environment and can also create the mentality that makes further implementation of advanced manufacturing 
technologies possible.

\section{Automated design in continuous process production}

Again only one Dutch food \& drink company - firm 19 - resides in this category. It combines true HRM with automation methods of the design function by means of $C A D, C A E$ and $C A P P$. The implementation of $C A D$ as well as CAE shows no significantly different perception of developments in the production environment. Two changes are, however, associated with CAPP: batch size and the amount of work subcontracted increases. The increase in batch size is a logical consequence of the more efficient planning of the production process, while the increase in subcontracting points to a decreasing complexity in the production environment within the company (Sorge, 1989). Both developments are not expected to have a large impact on the management of personnel. Although the production function in this company could therefore probably also function with traditional personnel management, the use of true HRM will make future implementation of advanced manufacturing technologies possible.

\section{Automated continuous process production}

This category contains two companies that only automated their production by implementing CPS. One of the companies, firm 5, employs traditional personnel management and the other, company 6 , evolving HRM. Both are Dutch chemical companies. The only significantly different perception of developments in the production environment is that there is no increase in integration between the different stages of production. This makes sense, since more integration between production stages than is achieved in automated continuous process production is hardly physically possible. The impact on personnel is therefore expected to be limited, so company 5 with traditional personnel management as well as company 6 with evolving HRM employ a compatible HRM-technology combination.

\section{Flexible continuous process production}

Four companies are categorized in flexible continuous process production. In addition to CPS, they also employed other automation methods in production.

Companies 7 - a Dutch chemical company - and 18 - a Dutch food \& drink company - that both employ traditional personnel management, automated their production by implementing CPS and CAM, their planning system through MRP and their design function with $C A D$ and $C A E$. They therefore face a production environment in which the number of people involved in design and development increases and no further integration of production stages is perceived. Both developments were discussed above. In combination, however, they are likely to create more complexity in the production environment. Although the use of CAD and CAE was not associated with a significantly different perception of developments in the production environment they may, in combination with MRP. point towards an attempt to make production of a larger number or variety of products feasible without, through CPS, losing efficiency. If this is the case, 
traditional personnel management constrains this development. If this is not the case and merely increasing efficiency is the objective, traditional personnel management will not hinder this. The question then, however, remains why implementation of so many automation methods was necessary and whether the efficiency benefits gained will offset the costs incurred.

Company 1 - a British chemical company - manages its personnel through imposed HRM and has automated its production function by means of CAM and CPS and its design function with CAD. The only significantly different perception of developments in its production environment is associlated with CPS: there is no increase in integration between the stages of production. Since the impact on the management of personnel is therefore limited, imposed HRM is appropriate.

Finally, company 15, a Dutch food \& drink company with a true HRM approach uses CAM, CPS and MRP. It therefore faces developments similar to those for companies 7 and 18. With a true HRM approach, however, it is expected to be able to cope with any possible future changes.

The results on the technology-HRM fit for all the companies analyzed are summarized in Table 6.7 .

\begin{tabular}{|c|c|c|c|}
\hline & $\begin{array}{l}\text { NO FIT: inconsistent } \\
\text { HRM technology } \\
\text { combinations }\end{array}$ & $\begin{array}{l}\text { FIT: consistent HRM- } \\
\text { technology } \\
\text { combinations }\end{array}$ & $\begin{array}{l}\text { "OVER FIT: too much } \\
\text { HRM for technology } \\
\text { employed }\end{array}$ \\
\hline $\begin{array}{l}\text { Large batch and } \\
\text { mass production }\end{array}$ & $\begin{array}{l}\text { Company } 17 \\
\text { Company } 22\end{array}$ & $\begin{array}{l}\text { Company } \# 16 \\
\text { Company } \$ 4 \\
\text { Company } \$ 9 \\
\text { Company } \$ 12 \\
\text { Company } \$ 13 \\
\text { Company } 10 \\
\text { Company } \# 11 \\
\text { Company } 3\end{array}$ & \\
\hline $\begin{array}{l}\text { Continuous process } \\
\text { production }\end{array}$ & & $\begin{array}{l}\text { Company } \# 5 \\
\text { Company } \# 7 ? \\
\text { Company } \# 18 \text { ? }\end{array}$ & $\begin{array}{l}\text { Company } 14 \\
\text { Company } 19 \\
\text { Company } 6 \\
\text { Company } 1 \text { ? } \\
\text { Company } 15 \text { ? }\end{array}$ \\
\hline
\end{tabular}

Table 6.7: Techmology-HRM fit in the chemical and food \& drink companies

\subsection{Conclusion}

In this chapter the HRM-production technology combinations that the companies employ are analyzed in two steps. Firstly, it is examined how the implementation of advanced manufacturing technologies alters the production environment in large batch and mass production on the one hand and in continuous process production on the other. Secondly, the impact of these changes on the management of 
personnel is explored. Our sample reveals that the impact of advanced manufacturing technologies is largest in large batch and mass production, mainly due to a perceived increase in integration between the stages of production and a decrease in inventories of work-in-progress and final products. The demands posed on the management of personnel are therefore higher in large batch and mass production than in continuous process production. The only incompatible HRMtechnology combinations were maybe therefore found in large batch and mass production, since in continuous process production traditional personnel management provides a sufficient match in most cases. Both companies where inconsistent combinations are detected employ traditional personnel management in conjunction with a manufasturing technology that requires a more flexible management of employees. Because the impact of advanced manufacturing technologies is less severe in continuous pracess production, five companies with continuous process production pursue HRM policies that are too advanced for the production technology implemented. All the other companies are found to pursue a consistent combination of HRM and technology policy. The findings are summarized in Figure 6.2. What, unfortunately, could not be determined is the direction of the

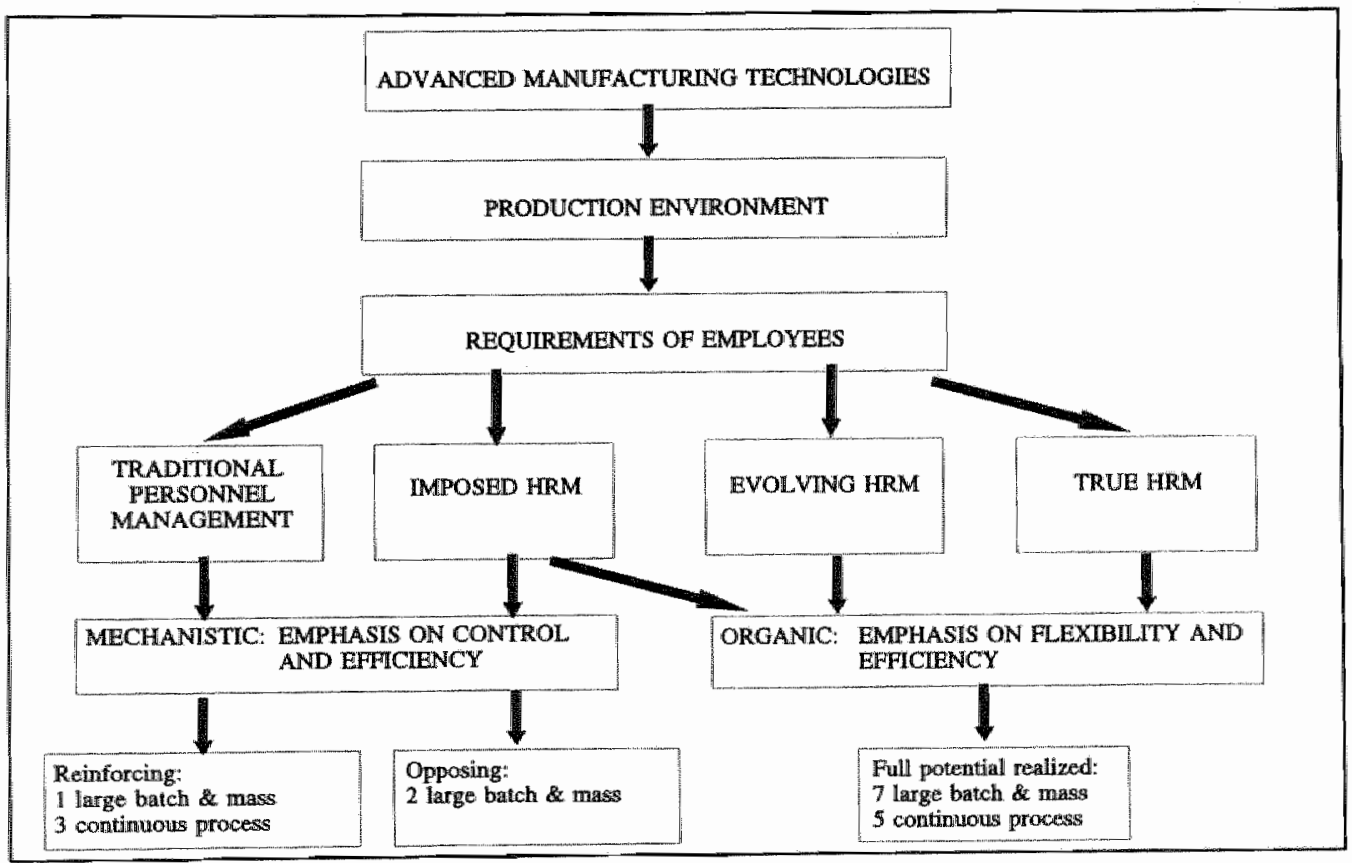

Figure 6.2: The relationship between advanced manufacturing technologies and the management of personnel/human resources 
relationships summarized in Figure 6.2. It can, judging from the number of consistent combinations, be concluded that interaction between the manufacturing technology, work organization and HRM policy indeed exists and that maybe even, judging from the number of "over" fits, limited investment in advanced manufacturing technologies can be compensated by a larger investment in HRM. The larger investment in HRM would then influence the work organization in such a way that the same net effect results as when the work organization would be changed through use of advanced manufacturing technologies: namely, increased efficiency and flexibility. More research on this proposition, however, is necessary to draw more definite conclusions.

Furthermore, as was already indicated in Section 6.3, the discussion on the HRM-technology combinations can be but tentative for four reasons. Firstly, the benchmark used to evaluate the impact of the implementation of advanced manufacturing technologies is the average perception of the chemical and food \& drink companies in the sample. Since this sample is by no means intended to be representative of the entire chemical and food \& drink population isee Chapter 2), further research in a broader context is necessary to see if the perceived changes in the production environment after the implementation of advanced manufacturing technologies, indeed hold. Secondly, the content of the HRM categories remained uncovered (see also Chapter 5), making the extent to which HRM programs are implemented when a HRM policy is pursued impossible to determine. Thirdly, also no information is available on the date of implementation of the advanced manufacturing technologies. The date of implementation is important to gain an understanding of how well accustomed the companies already are to the new production environment. If the implementation took place a considerable time ago, the changes in the production environment may be underestimated due to the fact that the companies grew accustomed to a higher level of complexity and thus not perceive this anymore. When this is indeed the case, it is possible that in the cases where traditiomal personnel management is, as yet, not in conflict with the manufacturing technology employed, still a misfit exists. Finally, the competitive environment and the generic strategy pursued influence the way in which a company manages its employees when advancied manufacturing technologies are implemented. For example, HRM policies that emphasize training and development of employees might be necessary in a competitive environment in which quality is of utmost importance to survive, while in an environment in which lowest cost are crucial traditional personnel policies prevail iChild, 1987\%. The same reasoning applies to whether flexibility or efficiency considerations guide the generic strategy pursued. This, however, is the topic of Chapter 7. 


\title{
CHAPTER 7
}

\section{PUTTING THE PIECES OF THE PUZZLE TOGETHER:}

\author{
PERFORMANCE IMPLICATIONS
}

The Chapters 3 until 6 discussed the separate relationships between the competitive environment and generic strategies (Chapter 3), the technological setting, the competitive environment and generic strategies (Chapter 4 , the HRM/personnel policies, the competitive environment and generic strategies (Chapter $5 /$ and the relationship between the technological setting and HRM (Chapter 6). At the end of each chapter a conclusion was reached on the fit between the respective elements. This chapter integrates these separate findings and attempts to test the performance implications of organizational alignment. The question guiding the analysis is whether companies in which a fit between all the different elements is established outperform those companies where no coherent combinations are found.

Section 7.1 provides an overview of how performance of organizations can be measured and, by means of illustration, discusses a sample of empirical studies. Section 7.2 describes the integrated generic strategy - competitive environment specific strategy profiles of the organizations in our sample, while Section 7.3 addresses the performance implications. Because significant differences appeared between the Netherlands and Great Britain on the one hand and between the food \& drink and chemical industry on the other, the profiles of the companies were evaluated in their awn country and industry context. Support is provided for the hypothesis that companies operating with an internally consilstent technology. HRM combination that is alligned to the competitive environment and generic strategy, outperform those that suffer from inconsistencies. Section 7.4, finally, presents a conclusion. The relationships studied in this chapter are summarized in Figure 7.1

\subsection{Different approaches in performance measurement}

The analyses performed in the previous chapters were based on the assumption that coherent environment, generic and specific strategy gestalts would result in better performance. The measurement of performance should reflect this 


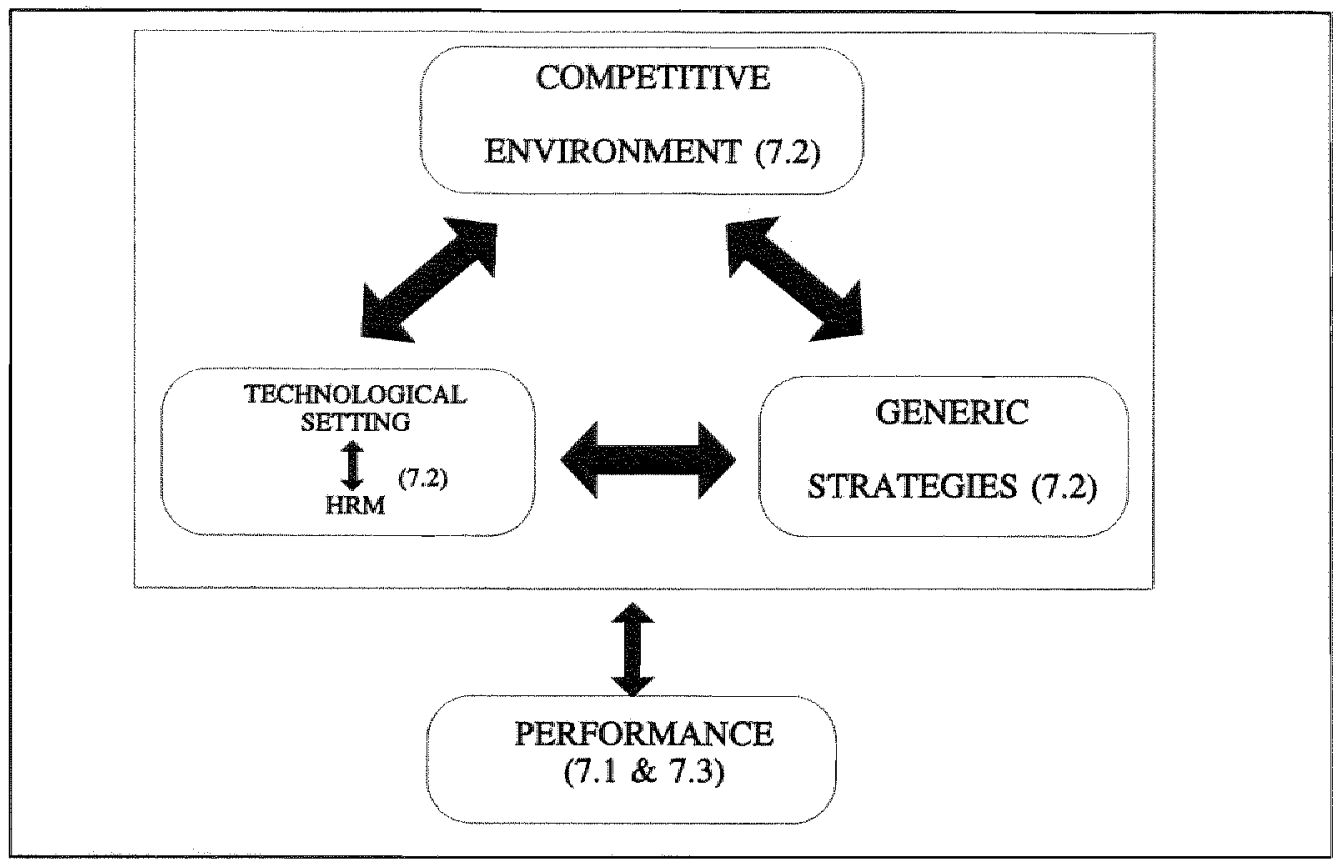

Figure 7.1: The relationship between the competitive environment, generic and specific strategies and performance

assumption, which is a major problem in strategy research (Chakravarthy, 1986; McGuire, Schneeweis \& Hill, 1986; Venkatraman \& Vasudevan Ramanujam, 1986). To guide the discussion on the conceptualization of performance a distinction is made between the type of performance data collected on the one hand and how the data are obtained on the other. Venkatraman \& Vasudevan Ramanujam (1986) provide a classification into ten categories based on two dimensions. These dimensions are the conceptualizations of business performance in terms of financial and operational (non-financial) indicators on the one hand and sources of data divided into primary and secondary on the other. Each of these dimensions are subsequently discussed below, starting with the type of data collected.

The most widely used indicators of performance have been accounting-based (McGuire, Schneeweis \& Hill, 1986). Accounting-based measures include Return on Investment (ROI), Return on Sales (ROS), Growth in Revenue (GIR) and Return on Assets (ROA). The focus on the sole use of accounting-based measures is surprising since many limitations of this approach appear when employed to estimate the effect of strategies or the ability of the company to match internal and external conditions (Chakravarthy, 1986; McGuire, Schneeweis \& Hill, 1986). For one, it assumes that $\mathrm{ROI}$ or ROA are the prime and only objectives of the organization, which is very unlikely. Furthermore, although accounting procedures 
are rooted in legislation and generally accepted practices, there is still scope for manipulating in the way liabilities and assets are presented. Also, comparing results across countries is difficult because of differences in legislation. Next, the lime period that accounting-based measures consider is limited. A onewear period is probably too short to measure the impact of strategy, while in multi-year averages the impact of strategic decisions may be blurred by other nonstrategic effects. Finally, the level at which the data are aggregated may cause difficulties in assessing the impact of strategy, since the effects of lower unit's actions are averaged out in the aggregated whole.

A solution for these problems was sought in using financial market based figures, such as market to book ratio or return on shareholder's wealth. These measures attempt to capture the firm's potential for future performance by calculating the ratio of stock price to book value per share (Brealey \& Myers, 19847. Although these address some of the problems mentioned above, they also assume that the impact of strategy can be assessed using a single criterion (Chakravarthy, 1986). Further attempts to circumvent this problem by deriving composite measures of performance - like the bankruptcy model of Altman (1971) . still only take the stockholder into account as the only and most important stakeholder (Brown \& Laverick, 1994). One approach that considers the various stakeholders is the 'balanced scorecard technique' (Kaplan and Norton, 1992 \& 1993). It provides a set of measures on performance that are both financial and operational and that address performance from four perspectives. First, again, from a financial perspective, including measures like return on capital employed, cash flow and profitability. Second, from a customer perspective measures such as market share, pricing and customer satisfaction indices are covered. Third, the internal business perspective comprises measures on internal key success factors. Finally, the innovation and learning perspective deals with how the company can continue to improve and create value, and thus includes measures as percentage of revenue from new products or services, revenues per employee and employee satisfaction. The only difficulty of this type of performance measurement in strategy research is, however, that the scorecard changes in different environments - and thus comparison between companies becomes difficult - and that a lot of the information required is possibly (still) unavailable in the companies. This approach is, probably for this reason, not encountered frequently in strategy research. How performance is measured in the sample of empirical studies discussed in Chapter 1 , is presented in Table 7.1. As can be revealed from the table, the vast majority of studies employs single or composite measures of performance, while only five studies - Chakravarthy 11986), Govindarajan (1988), Parthasarthy \& Sethi (1992), Dvir. Segev \& Shenhar (1993) and Thomas, Clark \& Gioia (1993) - also consider other stakeholders than stockholders.

The sources of data can, as was discussed earlier, be primary or secondary. 
Data from primary sources are directly collected from organizations, usually by questionnaires or interviews. Data from secondary sources are data from publicly available records (Venkatraman \& Vasudevan Ramanujam, 1986). Although the information on performance obtained from primary sources is subjective, it can circumvent four problems associated with 'objective' data (Powell, 1992): 1) when accounting-based measures are used to assess performance, differences in accounting conventions between companies and countries can seriously diminish the objectivity of financial measures; 2) when divisions or business units within companies are the unit of analysis, objective financial measures are often hard to obtain; 3) when the respondent is the managing director, it can be assumed that they are reasonably well informed on the financial position of the company and since they are involved in the strategy process their perception of how well the company is doing is at least as important; and, finally, 4l when performance measures beyond financial information are taken into account, objective data are hardly ever available. Furthermore, subjective assessments of performance are found to be consistent with objective measures (Dess \& Robinson, 1984 and Govindarajan \& Fisher, 1990).

\begin{tabular}{|c|c|c|c|}
\hline Authar & Theme & Sample & Measurement of performance \\
\hline $\begin{array}{l}\text { Chakravarthy } \\
(1986)\end{array}$ & $\begin{array}{l}\text { Iclentification of } \\
\text { measures of strategic } \\
\text { performance that } \\
\text { distinguish well- } \\
\text { adapted from mal- } \\
\text { adapted firms }\end{array}$ & $\begin{array}{l}14 \text { firms in US } \\
\text { computer } \\
\text { induistry }\end{array}$ & 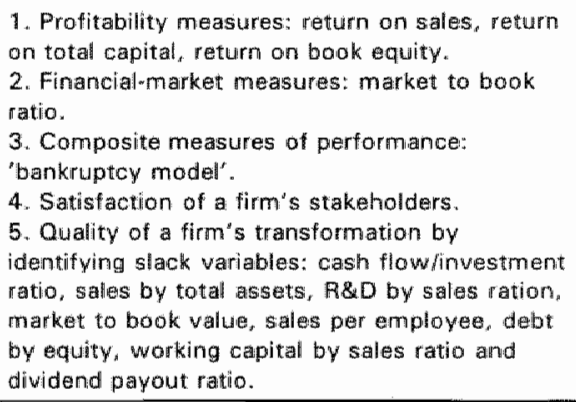 \\
\hline $\begin{array}{l}\text { Conant, } \\
\text { Mokwa \& } \\
\text { Rajan } \\
\text { Varaclaralan } \\
(1990)\end{array}$ & $\begin{array}{l}\text { Relationship between } \\
\text { strategic types, } \\
\text { distinctive marketing } \\
\text { competancies and } \\
\text { organzational } \\
\text { performance }\end{array}$ & $\begin{array}{l}406 \\
\text { organizations } \\
\text { in Ambrican } \\
\text { helalth } \\
\text { maintenance } \\
\text { Industiry } \\
\end{array}$ & $\begin{array}{l}\text { Subjective self report made up of two items that } \\
\text { respondents were asked to evaluate on a } 7 \text { point } \\
\text { scaler: } \\
\text { 1. profitability relative to competitors; and } \\
\text { 2. performance in reference to Rol. }\end{array}$ \\
\hline $\begin{array}{l}\text { Cool } 2 \\
\text { Dierickx } \\
\text { (1993) }\end{array}$ & $\begin{array}{l}\text { 1) Are there } \\
\text { meaningful } \\
\text { differences in weffects } \\
\text { of within group } \\
\text { rivalry on firm } \\
\text { pertormance? } \\
\text { 2) Are these } \\
\text { conditions of rivalry } \\
\text { driven by strategic } \\
\text { group structure? }\end{array}$ & $\begin{array}{l}\text { US pharma- } \\
\text { ceutical } \\
\text { industry }\end{array}$ & $\begin{array}{l}\text { Divisionall profitability meastured by return on } \\
\text { sales fratio of net income before interest and } \\
\text { taxes to total salest. }\end{array}$ \\
\hline
\end{tabular}




\begin{tabular}{|c|c|c|c|}
\hline Authar & Theme & Sample & Measurement of performance \\
\hline $\begin{array}{l}\text { Dess \& Dawis } \\
(1984)\end{array}$ & $\begin{array}{l}\text { Plelitionship between } \\
\text { gemeric strategies, } \\
\text { strategic group } \\
\text { membership and } \\
\text { performance }\end{array}$ & $\begin{array}{l}28 \text { non } \\
\text { diversified } \\
\text { firms in the } \\
\text { US paint and } \\
\text { allied products } \\
\text { ingustry }\end{array}$ & $\begin{array}{l}\text { Profitability was measured by sales growh } \\
\text { derived from fouryear total firm sales data and } \\
\text { average after lax retum on total assets. }\end{array}$ \\
\hline $\begin{array}{l}\text { Duir, Segev \& } \\
\text { Shenhar } \\
\| 19931\end{array}$ & $\begin{array}{l}\text { Relationship between } \\
\text { investment in } \\
\text { technological } \\
\text { progress of } \\
\text { defenders, analyzers } \\
\text { and prospectors and } \\
\text { their level of short- } \\
\text { and long-term } \\
\text { success }\end{array}$ & $\begin{array}{l}180 \text { firms in } \\
\text { electronic and } \\
\text { computer } \\
\text { industry. } \\
\text { Country could } \\
\text { not be } \\
\text { specified. }\end{array}$ & $\begin{array}{l}\text { Four dimensions of performance: } \\
\text { 1. profitability level: } \\
\text { 2. generating orders; } \\
\text { 3. generating new opportunities; and } \\
\text { 4. preparing the infrastucture for the future. } \\
\text { Operationalization not clear from anticle. }\end{array}$ \\
\hline $\begin{array}{l}\text { Govind arajan } \\
\text { (1988) }\end{array}$ & $\begin{array}{l}\text { The reliationship } \\
\text { between competitive } \\
\text { strategy. } \\
\text { administrative } \\
\text { mechanisms and their } \\
\text { interactive effect on } \\
\text { performance }\end{array}$ & $\begin{array}{l}\text { 24. US firms } \\
\text { on Fortune } \\
500 \text { Hist in } \\
\text { various } \\
\text { industries }\end{array}$ & 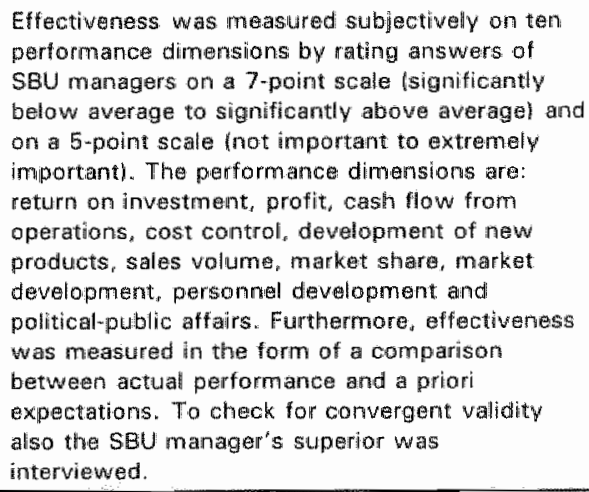 \\
\hline $\begin{array}{l}\text { Govindarajan } \\
\text { \& Fisher } \\
\text { (1990 }\end{array}$ & $\begin{array}{l}\text { Rielationship between } \\
\text { control systems. } \\
\text { resource sharing } \\
\text { between SBU and } \\
\text { other units. } \\
\text { competitive strategy } \\
\text { and performance }\end{array}$ & $\begin{array}{l}24 \text { US firms } \\
\text { on Fortune } \\
500 \text { list in } \\
\text { various } \\
\text { ondustries }\end{array}$ & See Govindarafian $(1988)$ \\
\hline $\begin{array}{l}\text { Habib } \\
\text { Victor }(1991)\end{array}$ & $\begin{array}{l}\text { Reldtionship between } \\
\text { strategy, structure } \\
\text { and performance in } \\
\text { MNCs }\end{array}$ & $\begin{array}{l}144 \text { US based } \\
\text { MNCs, } 72 \text { in } \\
\text { services and } \\
72 \text { in } \\
\text { manufacturing }\end{array}$ & $\begin{array}{l}\text { Performance was masured as the difference } \\
\text { between the average MNC return on assets and } \\
\text { the respective industry return on ascets. Hetum } \\
\text { on assats data were callected for two years. }\end{array}$ \\
\hline $\begin{array}{l}\text { Hambrick } \\
\text { (1983a) }\end{array}$ & $\begin{array}{l}\text { Development of a } \\
\text { typolagy of mature } \\
\text { industrial product } \\
\text { enviromments }\end{array}$ & $\begin{array}{l}200 \text { firms in } \\
\text { plMs deta } \\
\text { base }\end{array}$ & Not applicable \\
\hline $\begin{array}{l}\text { Hambrick } \\
\text { (1983tit }\end{array}$ & $\begin{array}{l}\text { How is thigh } \\
\text { performance } \\
\text { achieved in two } \\
\text { types of industry } \\
\text { environiments: in the } \\
\text { disciplined ciapital } \\
\text { goods makers and in } \\
\text { the aggressive } \\
\text { makers of complex } \\
\text { capital goods? }\end{array}$ & $\begin{array}{l}164 \text { firms in } \\
\text { PuMS data } \\
\text { base }\end{array}$ & $\begin{array}{l}\text { Performance was measured as a four }{ }^{2} \text { ear } \\
\text { average return on investment calculated als pretax } \\
\text { proflits divided by net inver tment. }\end{array}$ \\
\hline
\end{tabular}




\begin{tabular}{|c|c|c|c|}
\hline Author & Theme & Sample & Measurement of pertormance \\
\hline $\begin{array}{l}\text { Herbert } \\
\text { Deresky } \\
11989 \text { ? }\end{array}$ & $\begin{array}{l}\text { Empinical } \\
\text { development of a } \\
\text { typology of generic } \\
\text { strategies and the } \\
\text { content of each type }\end{array}$ & $\begin{array}{l}\text { 34. Canadian } \\
\text { firms in } \\
\text { warious } \\
\text { industrias }\end{array}$ & Not applicable \\
\hline $\begin{array}{l}\text { Koth \& Orne } \\
119891\end{array}$ & $\begin{array}{l}\text { To develop a } \\
\text { conceptual } \\
\text { framework for } \\
\text { considering the fit } \\
\text { between structire, } \\
\text { strategy, technology } \\
\text { and performancie in } \\
\text { manufacturing } \\
\text { competitiveness }\end{array}$ & Not applicable & Not applicabile \\
\hline $\begin{array}{l}\text { Mckea, Rajan } \\
\text { Varradarajan } \\
\text { \& Pride } \\
\text { (1989) }\end{array}$ & $\begin{array}{l}\text { Effectiveness of a } \\
\text { strategy in the Miles } \\
\text { \& Sinow }(1978) \\
\text { fypology is } \\
\text { contingent upom the } \\
\text { dynamios of the } \\
\text { market }\end{array}$ & $\begin{array}{l}560 \text { banks in } \\
7 \text { US staites }\end{array}$ & $\begin{array}{l}\text { Three measures of performance were used: } 11 \\
\text { percentage charage in share of total bank deposits } \\
\text { in the market for a two-year period; } 21 \text { revurn on } \\
\text { assets for one-year; and } 3 \text { ifetum on equity for } \\
\text { ane vear. }\end{array}$ \\
\hline $\begin{array}{l}\text { Miller } \text { Dess } \\
(1993)\end{array}$ & $\begin{array}{l}\text { To evaluate Porter's } \\
(1980) \text { generic } \\
\text { strategies, on the } \\
\text { basis of simplicity, } \\
\text { alccuracy and } \\
\text { generalizability. } \\
\text { through an empirical } \\
\text { analysis of PIMS data }\end{array}$ & $\begin{array}{l}200 \text { firms in } \\
\text { PIMS database }\end{array}$ & $\begin{array}{l}\text { Performance was considered as a multi- } \\
\text { dimensional concept consisting of } 11 \text { proffitability } \\
\text { measured as the pretax/pre-interest return an } \\
\text { investment and the casth filow on investment and } \\
\text { 2) growth measured as siales growth and market } \\
\text { share gained. As a measure of predichability of } \\
\text { financial performance 'Rol instability'. } \\
\text { operationalized as the variation around a four. } \\
\text { year trend line, was used. }\end{array}$ \\
\hline $\begin{array}{l}\text { Miller \& } \\
\text { Frissen } \\
\text { (1986a) }\end{array}$ & $\begin{array}{l}\text { Can Porter's } 119801 \\
\text { generic strategles be } \\
\text { detected when } \\
\text { evaluating data in the } \\
\text { PIMs database? }\end{array}$ & $\begin{array}{l}102 \text { sBUs in } \\
\text { consumer } \\
\text { durable } \\
\text { industries from } \\
\text { PHMS database }\end{array}$ & Not applicable \\
\hline $\begin{array}{l}\text { Nillar } 8 \\
\text { Frigenth } \\
(19866)\end{array}$ & $\begin{array}{l}\text { Are there } \\
\text { performance } \\
\text { differences between } \\
\text { different strategy } \\
\text { clusters? }\end{array}$ & $\begin{array}{l}102 \text { spuls in } \\
\text { consumeir } \\
\text { durable } \\
\text { industries from } \\
\text { PINS dattabasa }\end{array}$ & $\begin{array}{l}\text { Pentormance is measured as return on investment } \\
\text { and market share growth. }\end{array}$ \\
\hline $\begin{array}{l}\text { Mitler } 8 \\
\text { Friesen } \\
\text { (1984) }\end{array}$ & $\begin{array}{l}\text { Organizations exthibit } \\
\text { an internat } \\
\text { congruence between } \\
\text { enwironment: } \\
\text { strategy, structure } \\
\text { and deciston making } \\
\text { methods in each } \\
\text { phase of the } \\
\text { conporate life cycle } \\
\text { This match changes } \\
\text { as an organization } \\
\text { moves to the next } \\
\text { phase }\end{array}$ & $\begin{array}{l}36 \text { US } \\
\text { companies }\end{array}$ & Not applicable \\
\hline
\end{tabular}




\begin{tabular}{|c|c|c|c|}
\hline Author & Theme & Sample & Measurenent of parformance \\
\hline Miller $(1988)$ & $\begin{array}{l}\text { Relationship between } \\
\text { Porter's } 11980 \text { ) } \\
\text { business strategies. } \\
\text { environment, } \\
\text { structure and } \\
\text { performance }\end{array}$ & $\begin{array}{l}89 \text { Canadian } \\
\text { firms in } \\
\text { various } \\
\text { industries }\end{array}$ & $\begin{array}{l}\text { Performance is operationalized by a combination } \\
\text { of objective and subective measures. The } \\
\text { objective measures are five-vear averages of } \\
\text { return an investment and grow th in net incoma. } \\
\text { For the subjective measure the CEO was asked } \\
\text { for a live year period to compare profitability of } \\
\text { their firm to that of competitors. }\end{array}$ \\
\hline $\begin{array}{l}\text { Militer } \\
\text { 1987 a }\end{array}$ & $\begin{array}{l}\text { Relationship between } \\
\text { strategy-making and } \\
\text { organizational } \\
\text { structures and its } \\
\text { implications for } \\
\text { performance }\end{array}$ & $\begin{array}{l}97 \text { Canadian } \\
\text { firms in } \\
\text { various } \\
\text { industries }\end{array}$ & See Miller (1988). \\
\hline $\begin{array}{l}\text { Mallieir } \\
\text { M } 987 \mathrm{~b})\end{array}$ & $\begin{array}{l}\text { Relationship between } \\
\text { dimenisions of } \\
\text { strategy content. } \\
\text { organizational } \\
\text { structure and } \\
\text { environment }\end{array}$ & $\begin{array}{l}161 \text { US firms } \\
\text { and } 110 \\
\text { Canadian and } \\
\text { Australian } \\
\text { firms in } \\
\text { various } \\
\text { industries }\end{array}$ & Not applicable \\
\hline Miller 11986$)$ & $\begin{array}{l}\text { Relationship between } \\
\text { several common } \\
\text { configurations of } \\
\text { strategw and } \\
\text { structure }\end{array}$ & Not applicable & Not applicable \\
\hline $\begin{array}{l}\text { Milliman; Von } \\
\text { Glinow \& } \\
\text { Natthan } \\
\text { (1991) }\end{array}$ & $\begin{array}{l}\text { To diewelop a } \\
\text { framework on the } \\
\text { relationship between } \\
\text { organizational life } \\
\text { cycles and strategic } \\
\text { international HRM } \\
\text { and its implications } \\
\text { for fit and flexibility }\end{array}$ & Not applicable & Not applicable \\
\hline $\begin{array}{l}\text { Moprison } 8 \\
\text { Fich }(1992)\end{array}$ & $\begin{array}{l}\text { To develop a } \\
\text { taxonomy of } \\
\text { business-level } \\
\text { strategy in global } \\
\text { industries }\end{array}$ & $\begin{array}{l}115 \text { US firms } \\
\text { in global } \\
\text { industries }\end{array}$ & 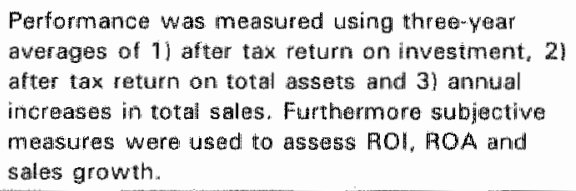 \\
\hline $\begin{array}{l}\text { Naman } 8 \\
\text { Slevin 11993. }\end{array}$ & $\begin{array}{l}\text { Relationship between } \\
\text { entrepreneursinip and } \\
\text { the firm's fit with the } \\
\text { environment }\end{array}$ & $\begin{array}{l}\text { 82. US virms in } \\
\text { adwanced: } \\
\text { technollogy } \\
\text { manufacturing }\end{array}$ & 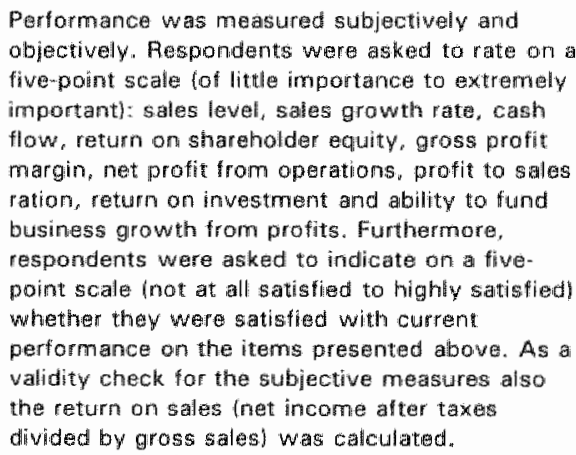 \\
\hline
\end{tabular}




\begin{tabular}{|c|c|c|c|}
\hline Author & Theme & Sample & Measurement of performance \\
\hline $\begin{array}{l}\text { Parkir } 2 \\
\text { Helms (1992) }\end{array}$ & $\begin{array}{l}\text { What are the } \\
\text { relationships between } \\
\text { singular and mixed } \\
\text { generic strategies in a } \\
\text { decine industry? }\end{array}$ & $\begin{array}{l}48 \text { US and } 39 \\
\text { UK firms in } \\
\text { the textile mill } \\
\text { products } \\
\text { hindustry }\end{array}$ & $\begin{array}{l}\text { Performance is measured subjectively by asking } \\
\text { respondents to rate on a fivewpoint sicale } \\
\text { lexcellent to poon: relative net profit, operating } \\
\text { performance, return on assets, sales reventhe } \\
\text { growth and employment growth for one and five } \\
\text { years. }\end{array}$ \\
\hline $\begin{array}{l}\text { Parthasarthy } \\
\text { \&ethi } \\
(1992)\end{array}$ & $\begin{array}{l}\text { To develop a } \\
\text { framework to studv } \\
\text { the impact of flexible } \\
\text { automation on } \\
\text { business strategy and } \\
\text { organizationals } \\
\text { structure. Can a link } \\
\text { with performance be } \\
\text { established? }\end{array}$ & Not applicable & $\begin{array}{l}\text { Performance should be measured using: } \\
\text { 1) gutput efficiency based performance measures } \\
\text { le.g. ROS and ROAl; and } \\
\text { 2) input efficiency based performance measures } \\
\text { le.g., product manulacturing cost and worker } \\
\text { productivityl. }\end{array}$ \\
\hline $\begin{array}{l}\text { Povelf } \\
119921\end{array}$ & $\begin{array}{l}\text { What are the } \\
\text { performance } \\
\text { consequences of } \\
\text { organizational } \\
\text { alignments in context } \\
\text { with the effects of } \\
\text { industry, market } \\
\text { share and strategy? }\end{array}$ & $\begin{array}{l}113 \text { US firms } \\
\text { in wood } \\
\text { upholstered } \\
\text { industry }\end{array}$ & $\begin{array}{l}\text { Performance was measured by three survey } \\
\text { questions concerning profitability, sales growth, } \\
\text { and overall financial performance ower the most } \\
\text { recent three fiscal years. }\end{array}$ \\
\hline $\begin{array}{l}\text { Mobinson } 8 \\
\text { Pearce } \\
(1988)\end{array}$ & $\begin{array}{l}\text { The influence of } \\
\text { plarming } \\
\text { sophistication on the } \\
\text { strategy-performance } \\
\text { reltationship }\end{array}$ & $\begin{array}{l}97 \text { US } \\
\text { manufacturing } \\
\text { tirms in } 60 \\
\text { different } \\
\text { industries }\end{array}$ & $\begin{array}{l}\text { Each CEO was asked to providle information on } \\
\text { firm sales, neturn on assets and return on sales } \\
\text { for the beginning and ending years of the fiwe- } \\
\text { year period under study. Subsequently, each CEO } \\
\text { was asked to provide a subjective evaluation on } \\
\text { 1) after tax return on total assets, 2) after tax } \\
\text { return on total sales, 3) firm total sales grown } \\
\text { over past five years and } 41 \text { overall firm } \\
\text { performance/success compared to other firms in } \\
\text { the incustry. }\end{array}$ \\
\hline Foth $\{1992\}$ & $\begin{array}{l}\text { To dietermine the } \\
\text { basic contiguration } \\
\text { and coorclination } \\
\text { patterns in medium- } \\
\text { sized firms in gllobal } \\
\text { industries to further } \\
\text { understand the } \\
\text { implemontation of } \\
\text { imternational strategy }\end{array}$ & $\begin{array}{l}126 \text { us } \\
\text { business in } 9 \\
\text { glabial } \\
\text { industries }\end{array}$ & 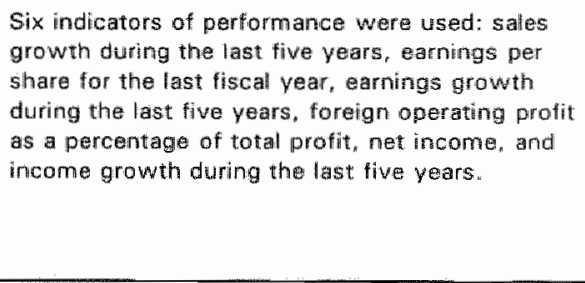 \\
\hline $\begin{array}{l}\text { Sohule: } \\
(1987) \text { and } \\
\text { Sohuler } 8 \\
\text { Jackson } \\
\text { (1987) }\end{array}$ & $\begin{array}{l}\text { Relationship between } \\
\text { organizational } \\
\text { strategy, organization } \\
\text { level and HRMA } \\
\text { practices }\end{array}$ & $\begin{array}{l}304 \text { business } \\
\text { units in } \\
\text { various } \\
\text { industries }\end{array}$ & Not applicable \\
\hline Shan (1990) & $\begin{array}{l}\text { What are the } \\
\text { determinants of } \\
\text { entiepreneurial high } \\
\text { technology firms to } \\
\text { torn cooperative } \\
\text { relationships? }\end{array}$ & $\begin{array}{l}278 \text { us firms } \\
\text { in bio } \\
\text { technology } \\
\text { industry }\end{array}$ & Not applicable \\
\hline
\end{tabular}




\begin{tabular}{|c|c|c|c|}
\hline Author & Theme & Sample & Measurement of performance \\
\hline $\begin{array}{l}\text { Smith. } \\
\text { Guthrie \& } \\
\text { Chen }(1989)\end{array}$ & $\begin{array}{l}\text { 1) To test the validity } \\
\text { of Miles and Sinow's } \\
\text { (1978/ typoliogy } \\
\text { 2) The relationstyip } \\
\text { between Miles and } \\
\text { Snow's strategies, } \\
\text { size and performance }\end{array}$ & $\begin{array}{l}47 \text { US } \\
\text { electronic } \\
\text { manufacturing } \\
\text { firms }\end{array}$ & $\begin{array}{l}\text { Performance was assessed using a subjective self } \\
\text { report on sales growth, profit as a percentage of } \\
\text { sales, retum on total assets and overall } \\
\text { performance. Olbjective data on return on total } \\
\text { assets were also collected to test the validity of } \\
\text { the self report. }\end{array}$ \\
\hline $\begin{array}{l}\text { Thomas. } \\
\text { Clark and } \\
\text { Gioia (1993) }\end{array}$ & $\begin{array}{l}\text { What are the direct } \\
\text { and indirect effects } \\
\text { of three strategic } \\
\text { sense-making } \\
\text { atcivities, scanning } \\
\text { inferpretation and } \\
\text { action, on } \\
\text { performance? }\end{array}$ & $\begin{array}{l}156 \text { US } \\
\text { hospitals }\end{array}$ & $\begin{array}{l}\text { Three measures of performance were used: } \\
\text { occupancy of hospital beds. profit per discharge } \\
\text { and admisions. }\end{array}$ \\
\hline $\begin{array}{l}\text { Venkatraman } \\
\text { \& Prescott } \\
\text { (1990 }\end{array}$ & $\begin{array}{l}\text { Does a business in } \\
\text { which the strategic } \\
\text { resources are alligned } \\
\text { to the requirements } \\
\text { of the enyironment, } \\
\text { outperform a } \\
\text { business in which } \\
\text { this is not the case? }\end{array}$ & $\begin{array}{l}1638 \text { SBUs } \\
\text { from PNMS } \\
\text { data base in } \\
\text { first sample } \\
\text { and } 82 \text { S SBUs } \\
\text { from PIMS } \\
\text { data base in } \\
\text { second sample }\end{array}$ & $\begin{array}{l}\text { Perlomance is measured as return on imwestment } \\
\text { of the business unit. }\end{array}$ \\
\hline White (1986) & $\begin{array}{l}\text { Relationship between } \\
\text { Porter's }\left(1980^{\prime}\right) \\
\text { generic strategies of } \\
\text { owerall cost } \\
\text { leadership and } \\
\text { differentiation, } \\
\text { organizational } \\
\text { comtext and } \\
\text { performance }\end{array}$ & $\begin{array}{l}69 \text { SBU's in } \\
\text { various } \\
\text { industries from } \\
\text { PIMS data } \\
\text { basie }\end{array}$ & $\begin{array}{l}\text { Business unit performance was operationalized als } \\
\text { four-year awerages of sales growth and pretax } \\
\text { return on investment. }\end{array}$ \\
\hline 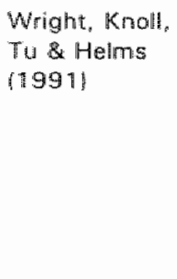 & $\begin{array}{l}\text { Relationship between } \\
\text { generic strategies of } \\
\text { low cost. } \\
\text { differentiation and a } \\
\text { combination of both } \\
\text { and performance } \\
\text { within the screw } \\
\text { machine products } \\
\text { industry }\end{array}$ & $\begin{array}{l}56 \text { US firms in } \\
\text { screw } \\
\text { machine } \\
\text { products } \\
\text { industry }\end{array}$ & $\begin{array}{l}\text { Two measures of performance are emploved: } \\
\text { fiwe-year average Rol calculated as net income } \\
\text { before taxes diwided by total inwestment and fiwe } \\
\text { year growth in ratative market shere calculated by } \\
\text { dividing the growth in sales in each business by } \\
\text { the combined growth in salss of the three largest } \\
\text { competitors. }\end{array}$ \\
\hline $\begin{array}{l}\text { Zahura } 8 \\
\text { Covinn }(9993)\end{array}$ & $\begin{array}{l}\text { Relationship between } \\
\text { technology policw. } \\
\text { generic business } \\
\text { strategy and } \\
\text { performance }\end{array}$ & $\begin{array}{l}103 \text { US } \\
\text { manufactuing } \\
\text { based firms in } \\
28 \text { mature } \\
\text { industries }\end{array}$ & $\begin{array}{l}\text { Performance was measured by return on sales for } \\
\text { a three-year pertiod. }\end{array}$ \\
\hline
\end{tabular}

Table 7.1: Performance measures in a sample of empirical studies 1983-1993

Which performance measures are considered in our study is discussed in Section 7.3. Section 7.2 first describes the competitive environment, generic and specific strategy profiles of the Dutch and British food \& drink and chemical companies by integrating the findings of Chapters 3 to 6 . 


\subsection{Profiles of the companies: can consistent combinations of competitive environment, generic and specific strategies be found?}

In Chapters 3 to 6 a total of six different possible types of fit were analyzed: i) a generic fit between the competitive environment and the generic strategy pursued, ii) a specific fit between the technological setting and the generic strategy pursued, iii) a specific fit between the technological setting and the competitive environment, iw) a specific fit between the HRM policy and the generic strategy, v) a specific fit between the HRM policy and the competitive environment and, finally, vily a specific fit between the technological setting and the HRM policy. The combinations found in the companies are presented in Figure 7.2. Each of the different types of fit in each of the clusters in the food \& drink as well as chemical industry will be discussed subsequently. The numbers of the companies correspond to a short company description in Appendix $\mathrm{A}$.

\section{Food \& Drinks}

In cluster I four companies - 10, 11, 12 and 13 - demonstrate a perfect fit between all the different elements. In other words, they are internally consistent (technological setting-HRM fit) and have aligned this internal consistency with their generic strategy and the competitive environment. Whether company 20 can be included in this group as well remains unknown, since data on the technological setting are missing. However, the elements on which information was available generic strategy, competitive environment and HRM - form a consistent whole. The generic strategy pursued matches the conditions in the competitive environment, and the HRM policy is consistent with both the generic strategy and the competitive environment. Finally, company 9's technology is not advanced enough compared to the generic strategy, the competitive environment, the HRM policy and the other competitors operating in this cluster, although the generic strategy is alligned with the competitive environment and a matching HRM policy is pursued, Company 9, therefore, is expected to perform worse than the other companies in this cluster. The results per type of fit in cluster I are summarized in Table 7.2.

In cluster $\|$ companies 14,16 and 19 operate. Company 16 exhibits an internal consistency in the technology-HRM combination which in turn is aligned to the competitive environment. Nane of the specific strategies, however, match the generic strategy pursued, nor is the generic strategy in line with environmental requirements. Performance in this case does not necessarily suffer, however. As was suggested in Chapter 3, the strategy implemented could differ from the strategy formally stated. Given the consistency in the specific strategies and the alignment of those with the competitive environment, it is suspected that this is indeed the case here. Companies 14 and 19 theoretically exhibit a perfect fit on all elements, although - as was discussed in Chapter 5 - the use of true HRM in this 


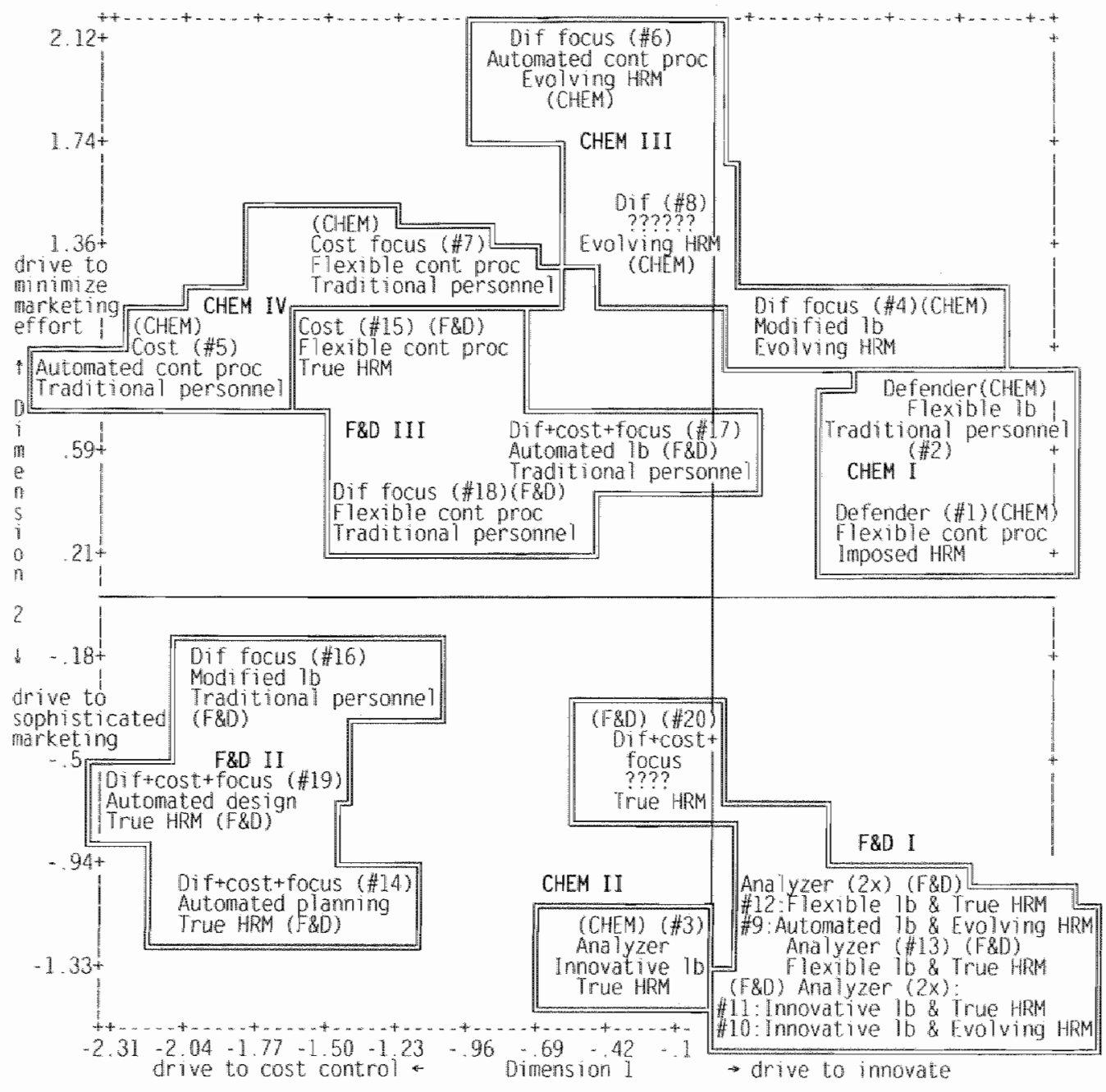
CHEM =
Chemicals
$F \& D=$
Food \& Drinks
$\mathrm{Dif}=$
Differentiation
Dif focus =
Differentiation focus
$\mathrm{Dit}+\cos \mathrm{t}+$ focus $=$
Combination of differentiation, cost leadership and locus
$\cos t=$
Cost leadership
Cont proc $=$
Continuous process production
$\mathbb{L b}=$
Large batch and mass production
Traditional personnel $=$
Traditional personnel management

Figure 7.2: Food \& drink and chemical clusters labeled with strategy-technologyHRM pairs 
type of environment with a very strong emphasis on cost may be redundant as the production technologies of automated design and automated planning in continuous process production would match traditional personnel management (see allso Chapter 6\%. It is striking, though, that both companies adopted true HRM while operating in very similar circumstances. The different types of fit in cluster 11 are summarized in Table 7.3 .

\begin{tabular}{|c|c|c|c|c|c|c|}
\hline $\begin{array}{l}\text { F\&D } \\
\text { CLUSTER }\end{array}$ & $\begin{array}{l}\text { Generic } \\
\text { strategy- } \\
\text { competitive } \\
\text { environment for }\end{array}$ & $\begin{array}{l}\text { Technohogr } \\
\text { strategy fit }\end{array}$ & $\begin{array}{l}\text { Technology- } \\
\text { anvironment } \\
\text { fit }\end{array}$ & $\begin{array}{l}\text { MAM - } \\
\text { strategy fit }\end{array}$ & $\begin{array}{l}\text { HRM - } \\
\text { enviromment } \\
\text { fit }\end{array}$ & $\begin{array}{l}\text { Technology } \\
\text { +HAM fit }\end{array}$ \\
\hline Company & $+1+$ & $-1-$ & -4 & $+1+$ & 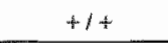 & $+1+$ \\
\hline Company 10 & $+1+$ & $t+1+$ & $48+$ & $+1+$ & $+1+$ & $+1+$ \\
\hline Company 11 & $+1+4$ & $+1+$ & $+1+$ & $+1+$ & $+1+$ & $+1+$ \\
\hline Company 12 & $H 1+$ & $+1+$ & $+1+$ & 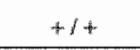 & $+1+$ & $+1+$ \\
\hline Company 13 & $41+$ & $+1+$ & $+1+$ & $+1+$ & $+1+$ & $+1+$ \\
\hline Company 20 & $41+$ & $?$ & $? ?$ & $+1+$ & $+1+$ & $? ?$ \\
\hline
\end{tabular}

Table 7.2: Different types of fit in food \& cluster 1

\begin{tabular}{|c|c|c|c|c|c|c|}
\hline $\begin{array}{l}\text { FSD } \\
\text { CLUSTER }\end{array}$ & $\begin{array}{l}\text { Generic } \\
\text { strategy" } \\
\text { competitive } \\
\text { epwironment fit }\end{array}$ & $\begin{array}{l}\text { Technology- } \\
\text { strategy fint }\end{array}$ & $\begin{array}{l}\text { Technology" } \\
\text { environment } \\
\text { fit }\end{array}$ & $\begin{array}{l}\text { HRWh } \\
\text { strategw fit }\end{array}$ & $\begin{array}{l}\text { HRM: } \\
\text { enwironment } \\
\text { fit }\end{array}$ & $\begin{array}{l}\text { Techmology } \\
\text { HAM Wir }\end{array}$ \\
\hline Company 14 & $+1+$ & $+1+\infty$ & $+1+$ & $+1+?$ & $+1+?$ & $+1+$ \\
\hline Companw 16 & $\infty$ & -1 & $+1+$ & $\%$ & $+1+4$ & $+1+$ \\
\hline Company 19 & +10 & $+1+$ & $+1+$ & $41+?$ & $41+?$ & $+1+$ \\
\hline
\end{tabular}

Table 7.3: Different types of fit in food \& cluster $/ 1$

Companies 15, 17 and 18 operate in food \& dirink cluster III. Company 15 in a way demonstrates a perfect fit between generic strategy and competitive environment on the one hand and technology and HRM on the other. The strange situation in this company, however "exists that the production technology employed - flexible continuous process production - and the HRM policy - true HRM - are too advanced for both the generic strategy as well as the competitive enviranment. However, when the investments in technology and HRM increase efficiency to such an extent that this reinforces the strategy pursued, performance will obviously not suffer since then a "perfect gestalt" exists. When this is not the case, and the additional investment impedes the effectiveness of a cost leadership strategy, performance will deteriorate. Company 17 suffers from a misalignment between the production technology and HRM policy. Moreover, although the HRM policy fits environmental 
conditions, it is not aligned with strategy. The technological setting also fits the environment and would match the generic strategy when cost is emphasized but not when differentiation receives more attention. Finally, company 18 only exhibits a fit on two elements: the technological setting is aligned with the generic strategy pursued and the HRM policy matches the environment. Traditional personnel management in this company is not necessarily inconsistent with the technological setting of flexible continuous process production. Since, as was explained in Chapter 6 , the impact of flexible continuous process production on the work organizations is limited. However, since this company has the least number of fits that could contribute to an internal or external consistency, the performance of this company is expected to be worse than company 15's or company 17 's. The types of fit in cluster III are summarized in Table 7.4 .

\begin{tabular}{|c|c|c|c|c|c|c|}
\hline $\begin{array}{l}\text { FQD } \\
\text { CLUSTEA III }\end{array}$ & $\begin{array}{l}\text { Generic } \\
\text { strategw- } \\
\text { competitive } \\
\text { enwironment fit }\end{array}$ & $\begin{array}{l}\text { Technology- } \\
\text { strategy fit }\end{array}$ & $\begin{array}{l}\text { Techrology- } \\
\text { environment } \\
\text { fit }\end{array}$ & $\begin{array}{l}\text { HRM } \\
\text { strategy ht }\end{array}$ & $\begin{array}{l}\text { HRM- } \\
\text { environment } \\
\text { fit }\end{array}$ & $\begin{array}{l}\text { Techmology } \\
\text { MPM Pit }\end{array}$ \\
\hline Company 15 & $1+$ & $41+?$ & $+1+?$ & $+14 ?$ & $+1+?$ & $+1+$ \\
\hline Company 17 & +1 & $+\%$ & $+4 t$ & $\%$ & $+x+1+$ & $-1-$ \\
\hline Compary 18 & $-f$ & $+1+$ & $-\mu$ & 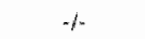 & $+1+$ & $+1-2$ \\
\hline
\end{tabular}

Table 7.4: Different types of fit in food \& drink cluster III

Summarizing, it is expected that - based on the fit between the competitive environment, generic strategy and specific strategies regarding technology and HRM - the best performing companies in the food \& drink sector are firms 10, 11 , 12. 13 in cluster $\|$ companies 14 and 19 in Cluster $\|$ and possibly company 15 in cluster III. The hypotheses on performance implications are summarized in Table 7.5 .

\begin{tabular}{|l|l|l|l|}
\hline Food \& drink industry & Cluster & Chuster $N$ & Cluster III \\
\hline Best performers & $10,11,12,13$ & 14,19 & $15 ?$ \\
\hline
\end{tabular}

Table 7.5: Hypotheses on performance implications in food \& drink industry

\section{Chemicals}

Chemical cluster I contains two companies. On the one hand, company I possesses internally consistent policies regarding production technology and HRM. These policies are aligned with the environment, but not with the generic strategy pursuled. Like company 16 in the food \& drink industry, performance does not 
necessarily have to suffer, as also in this case the strategy stated could differ from the strategy implemented. From the cansistency between the other elements, this is likely to be the case here. Company 2 , on the other hand, suffers from various inconsistencies. This firm can benefit from only two fits between the technological setting and the competitive environment on the one hand and HRM and the generic strategy on the other. The HRM-strategy pair, however, cannot deal with the requirements of the competitive environment, nor can it support the production technology employed. It is expected that this company will perform far worse than its competitor in this cluster. The types of fit present in chemical cluster 1 are summarized in Table 7.6 .

\begin{tabular}{|c|c|c|c|c|c|c|}
\hline $\begin{array}{l}\text { CHEMHCAL } \\
\text { CLUSTER }\end{array}$ & $\begin{array}{l}\text { Generic } \\
\text { strategy- } \\
\text { compotitive } \\
\text { environment fit }\end{array}$ & $\begin{array}{l}\text { Technology } \\
\text { strategy tht }\end{array}$ & $\begin{array}{l}\text { Technology- } \\
\text { environment } \\
\text { fit }\end{array}$ & $\begin{array}{l}\text { HRM } \\
\text { strategy fit }\end{array}$ & $\begin{array}{l}\text { HRM- } \\
\text { environment } \\
\text { fit }\end{array}$ & $\begin{array}{l}\text { Technolagy - } \\
\text { HAM it }\end{array}$ \\
\hline Company i & $H=$ & -1 & $+1+$ & $-x$ & $+1+$ & $+1+$ \\
\hline Company 2 & $\mu$ & $+\mu$ & $+1+4$ & $+1+$ & -4 & $\%$ \\
\hline
\end{tabular}

Table 7.6: Different types of fit in chemical cluster $/$

Only one company, number 3, resides in cluster II. Although no comparison with competitors in this group is possible, this firm is expected to perform well since it demonstrates a perfect fit between all the relationships analyzed. The types of fit for this company are summarized in Table 7.7 .

\begin{tabular}{|c|c|c|c|c|c|c|}
\hline $\begin{array}{l}\text { CHEMCAL } \\
\text { CLUSTEA }\end{array}$ & $\begin{array}{l}\text { Generic } \\
\text { strategy } \\
\text { competitive } \\
\text { enviromment fit }\end{array}$ & $\begin{array}{l}\text { Technology- } \\
\text { strategy fir }\end{array}$ & $\begin{array}{l}\text { Technokogy- } \\
\text { environment } \\
\text { fit }\end{array}$ & $\begin{array}{l}\text { HRM. } \\
\text { strategy fit }\end{array}$ & $\begin{array}{l}\text { HRM } \\
\text { entrironment } \\
\text { fit }\end{array}$ & $\begin{array}{l}\text { Technology - } \\
\text { HRM fit }\end{array}$ \\
\hline Company 3 & $+1+$ & $+1+$ & $+1+$ & $H+$ & $+1+$ & $+1+$ \\
\hline
\end{tabular}

Table 7.7: Different types of fit in chemical chuster II

Cluster III contains three firms of which none obtained a perfect match between all the elements. Company 4 is internally consistent and has matched its generic strategy as well as its HRM policy to the requirements posed by the competitive environment. The HRM policy is also aligned to the generic strategy. A misfit exists, however, concerning the production technology employed. Modified large batch and mass production is not advanced enough to fit environmental conditions as it impedes the proper implementation of a differentiation focus strategy. Company 6 suffers from inconsistencies too. Although the HRM - technology combinations represents a consistent match and HRM is aligned to the generic strategy and the competitive environment, the technological setting does not fit the 
generic strategy nor does the strategy fit the environmental conditions. In other words, automated continuous process production is geared towards efficiency, while the strategy and HRM policy is directed toward differentiation in a competitive environment with a slight emphasis on cost rather than on innovative behavior. If this company was trying to move towards an environment with a drive to innovate, it would have to adapt its technological setting. So, both companies, 4 and 6 , are not expected to obtain high performance. Company 8 , finally, has missing data on the technological setting. The HRM policy, however, is aligned to the gemeric strategy and the competitive environment. The fit between generic strategy and competitive environment is doubtful, since a differentiation strategy is pursued in an environment with a slightly larger emphasis on cost rather than differentiation. Therefore, despite the missing data, the performance of this company is neither expected to be high. The types of fit in this cluster are summarized in Table 7.8.

\begin{tabular}{|c|c|c|c|c|c|c|}
\hline $\begin{array}{l}\text { CHEMHCAL } \\
\text { CLUSTER HI }\end{array}$ & $\begin{array}{l}\text { Generic strategy } \\
\text { competitive } \\
\text { enviromment pit }\end{array}$ & $\begin{array}{l}\text { Technology } \\
\text { strategy fint }\end{array}$ & $\begin{array}{l}\text { Technalagy- } \\
\text { environment } \\
\text { fit }\end{array}$ & $\begin{array}{l}\text { HPM } \\
\text { strategr fir }\end{array}$ & $\begin{array}{l}\text { HRM- } \\
\text { enwironment } \\
\text { fit }\end{array}$ & $\begin{array}{l}\text { Technology } \\
\text { - HAM Fit }\end{array}$ \\
\hline Company 4 & $+1+$ & 4. & $\mu / x$ & $+1+$ & $+1+$ & +14 \\
\hline Company 6 & $-1-$ & -1 & $+1+$ & $+1+$ & +14 & $+1+$ \\
\hline Company 8 & -1 & $? ?$ & $? ?$ & $+1+$ & $+1+$ & $7 ?$ \\
\hline
\end{tabular}

Table 7.8: Different types of fit in chemical cluster III

Finally, chemical cluster IV contains companies 5 and 7. Company 5 exhibits a perfect alignment of all the elements as, in a way, is the case with company 7. Because firm 7 employed flexible continuous process production, which is too advanced for the generic strategy and the competitive environment unlless the main goal of the investments was to increase efficiency. So, high performance in this case will depend on whether the efficiency objective is realized and offsetting the costs incurred. In Chapter 6 is was furthermore argued that the combination of flexible continuous process production with traditional personnel management is not necessarily a misfit, since the impact of flexible continuous process production on the work organization was limited. Company 5 is expected to be among the better performing firms. The types of fit in this cluster are summarized in Table 7.9.

\begin{tabular}{|c|c|c|c|c|c|c|}
\hline $\begin{array}{l}\text { CHEMNCAL } \\
\text { CLUSTER N }\end{array}$ & $\begin{array}{l}\text { Gemeric } \\
\text { strategy } \\
\text { competitive } \\
\text { enwhonment fir }\end{array}$ & $\begin{array}{l}\text { Technology- } \\
\text { strategy fit }\end{array}$ & $\begin{array}{l}\text { Technology- } \\
\text { environment } \\
\text { fit }\end{array}$ & $\begin{array}{l}\text { MRM } \\
\text { strategy fit }\end{array}$ & $\begin{array}{l}\text { ARM- } \\
\text { environment" } \\
\text { fit }\end{array}$ & $\begin{array}{l}\text { Technologw } \\
\text { - Hirm fit }\end{array}$ \\
\hline Company 5 & $+1+$ & $40+$ & $+1+$ & $+1+$ & $+1+$ & $+1+$ \\
\hline Company 7 & $+1+$ & $41+?$ & $4 /+2$ & $+i+$ & $+1+$ & $410 ?$ \\
\hline
\end{tabular}

Table 7.9: Different types of fit in chemical cluster $N$ 
Summarizing, it is expected that - based on the types of fit present - the best performing firms in the chemical industry are companies 3 and 5 and possibly 7 . These hypotheses on performance implications are summarized in Table 7.10 .

\begin{tabular}{|l|l|l|}
\hline Chemical dridustry & Cluster & Cluster/ \\
\hline Best performers & 3 & $5,7 ?$ \\
\hline
\end{tabular}

Table 7.10: Hypotheses on performance implications in chemical industry

\subsection{Profiles of the food \& drink and chemical companies: performance implications}

As can be concluded from the literature review in section 7.1 , performance is ideally measured with criteria that are multi-faceted and thus move beyond financial measures only. Since the objectives of the organization are hardly ever limited to financial criteria only (Heijlties, Sorge \& Van Witteloostuijn, 1995 forthcomingh, non-financial measures that provide an indication of the level of satisfaction of other stakeholders besides the shareholder should be included. Furthermore, the time period considered should include a number of years to in be able to measure the impact of strategy and b) to rule out as much as possible the possibility that performance in one year is the result of external effects rather than the actions of the organization. Finally, performance measurement should be a combination of objective and subjective measures.

The measurement of performance proves to be difficult in our sample for several reasons. For one, only questions on financial performance were included in the questionnaire (see Appendix B). Moreover, these were limited to a one-year time period. Finally, because the unit of analysis in the vast majority of companies was a division or business unit of a larger corporation, the financial measures asked for were not always available. In the case that an entire company was the unit of analysis, the performance data were considered to be confidential. This implies that the answers provided by the respondents could not be checked using "objective"

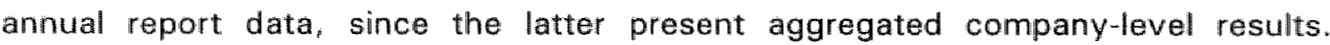
Although this sole use of subjective financial performance data is of course not ideal, it is all but exceptional in the empirical literature ffor example: Robinson \& Pearce, 1988; Conant, Mokwa \& Rajan Varadarajan, 1990; Parker \& Helms, 1992; and Powell, 1992).

The performance measures used in this study include Return on Sales (ROS). measured as the profit before taxes divided by total sales, and a subjective self report in which the managing director of the business unit, division or company was asked to assess their profitability compared to the previous vear, compared to 
national competitors and compared to competitors abroad. The choice for the performance criteria is pragmatic since only for ROS, data on all companies - except two-could be obtained. Before the performance implications of the types of fits of the companies are analyzed in Section 7.3.2, it is first investigated whether there are performance differences between the Netherlands and Great Britain in general and between the food \& drink and chemical industry in specific. Furthermore, the relationship between $R O S$ and the subjective self-report is discussed.

\subsection{Differences in performance between countries and industries}

Two of the difficulties with the accounting-based measures that were discussed in Section 7.1, are that comparison between countries as well as industries becomes difficult due to differences in accounting legislation and conventions. This section therefore examines these potential differences.

Mann-Whitney tests of ROS by country indicate that the eight British companies perform significantly better $(p=0.0263)$ than their Dutch counterparts. The average ROS in each country with the standard deviation and range of scores is presented in Table 7.11 .

\begin{tabular}{|l|c|c|c|c|}
\hline Country & Average ROS & Standard deviation & Minimum ROS & Maximum ROS \\
\hline Great Britain $(n=8)$ & 0.11 & 0.06 & 0.01 & 0.23 \\
\hline $\begin{array}{l}\text { The Netherliands } \\
(\mathrm{n}=10)\end{array}$ & 0.04 & 0.05 & -0.03 & 0.13 \\
\hline \hline
\end{tabular}

Table 7.11: Return on Sales (ROS) per country

Mann-Whitney tests on the subjective self-report measure of profitability compared to llast year by country confirm this pattern. Although the outcome is not significant $(p=0.1424)$, Dutch companies are less optimistic about their profitability compared to last year than their British counteirparts. However, when a Mann Whitney test is performed on ROS by profitability compared to the previous year a significant result appears $(p=0.0812)$ : indeed, companies with higher ROS feel they performed better this year than last year. What is striking is that when profitability compared to national or foreign competitors per country is analyzed, Dutch companies are more optimistic than their British colleagues. Although the results are again not significant $(p=0.1842$ and $p=0.1717$, respectively) this could indicate that the gap in ROS detected in our sample between the Netherlands and Great Britain is not as large as initially expected: British companies are not very confident about their functioning compared to competitors, while Dutch companies feel they outperform their competitors. This result can be partly explained by the financial 
institutional context of both countries. As was explained in Chapter 5, the British are more dependent on their -often large - shareholders than their Dutch counterparts, since they traditionally raise their capital mainly by issuing shares on the stock market (Lane, 1992). This implies that the British firms are more focused toward short-term financial results - such as profit - as these are the conditions under which the shareholders provide their resources. The Dutch firms, on the other hand, are allowed to be more leveraged at the expense of short-term profits due to higher interest costs.

When the food \& drink and chemical industry is examined, no significant difference in ROS appears. The average values with the associated standard deviations and ranges are presented in Table 7.12.

\begin{tabular}{|l|c|c|c|c|}
\hline \hline Industry & Average ROS & Standard deviation & Minimum ROS & Maximum ROS \\
\hline $\begin{array}{l}\text { Food \& Drinks } \\
(n=10)\end{array}$ & 0.08 & 0.04 & -0.01 & 0.13 \\
\hline Chemicals $(n=8)$ & 0.06 & 0.08 & -0.03 & 0.23 \\
\hline
\end{tabular}

Table 7.12: Return on Sales (ROS) per industry

Mann-Whitney tests on the subjective self report measures produce only one significant difference between the industries $(p=0.0684)$ on profitability compared to foreign competitors. The companies in the food \& drink industry are more confident about their profitability abroad than the chemical firms. This larger confidence of the food \& drink companies, although not significant, also appears on the other two subjective measures of profitability. Although the differences in ROS between the chemical and food \& drink industry are not significant, the slightly higher ROS for the food \& drink firms is not surprising. Especially the chemical industry has suffered from overcapacity, falling prices and increasing costs in 1991/1992, resulting in deteriorating margins (CEFIC, 1993). The food \& drink industry, however, retained a modest growth rate over that same time period (Commission of the European Communities, 1993).

The average return on sales per industry in both countries is summarized in Table 7.13. Especially because of the significant difference in ROS over countries, the performance implications of the profiles of the companies are evaluated in the context of Table 7.13. So, high or low performance is subject to the country, industry and cluster the companies operate in. This will be the topic of Section 7.3.2. 


\begin{tabular}{|l|c|c|c|c|}
\hline Mndustry per country & Average ROS & Standard deviation & Minimum ROS & Maximum ROS \\
\hline $\begin{array}{l}\text { Dutch food \& drinks } \\
\text { (n) }=5)\end{array}$ & 0.07 & 0.05 & -0.01 & 0.13 \\
\hline $\begin{array}{l}\text { British food \& drinks } \\
(n=5)\end{array}$ & 0.10 & 0.02 & 0.08 & 0.12 \\
\hline $\begin{array}{l}\text { Dutch chemicals } \\
\text { (n=5) }\end{array}$ & 0.02 & 0.03 & -0.03 & 0.05 \\
\hline $\begin{array}{l}\text { British chemicals } \\
\text { in }=3 \text { ? }\end{array}$ & 0.12 & 0.11 & 0.01 & 0.23 \\
\hline
\end{tabular}

Table 7.13: Return on Sales (ROS) per industry and country

The subjective self-report measures on profitability are only used to investigate differences between the clusters in the food $\&$ drink and chemical industry. The number of companies is too limited to perform non-parametric tests within the clusters.

\subsubsection{Fit and performance implications}

In Section 7.2. the profiles of the companies per cluster were discussed and hypotheses regarding their performance were developed. The performance of the companies in each cluster is evaluated in this section using the results of Tables 7.2 to 7.10 .

\section{Food \& Drinks}

Of the six companies that operate in food \& drink cluster 1 , four companies ." 10 , 11. 12 and 13 - demonstrated a perfect fit. Company 9 was expected to be the worst performer in this cluster. Predictions on the performance of company 20 were hard to make, since data on the technological setting are missing. Companies 9 to 13 are of British origin, while company 20 is Dutch. When the ROS for each company in the cluster is calculated it indeed appears that all the companies, but one, with a perfect alignment between all the elements are among the best performers. ROS for companies 10 to 13 are $0.12,0.12,0.08$ and 0.1 , respectively. It is surprising that company 12 has a ROS of 0.08 which makes it although still higher than the Dutch national average - one of the lowest performers in the British food \& drink sample. Although based on the number of fits investigated in this study no satisfactory explanation for this phenomenon is found. it is striking that the highest performers, with a ROS of 0.12 , both employ innovative large batch and mass production, while companies 12 and 13 both employ flexible large batch and mass production. So, maybe only investments in the most advanced production technology generate above average performance in this type of environment, thereby making even flexible large batch and mass 
production not advanced enough. It remains surprising, though, that company 9 still reveals a ROS of 0.08 . The only Dutch company in the cluster, 20 , has a ROS of 0.07 , which is equal to the Dutch industry average. Although the key data are missing, this firm is therefore suspected to possess a production technology that at least meets some of the requirements posed by the generic strategy and the competitive environment. The production technology is not advanced enough. though, to contribute to superior performance. The ROS of the companies in cluster I and the respective national averages are summarized in Table 7.14.

\begin{tabular}{|c|c|c|c|c|}
\hline Food \& Drinks & Company number & Nationality & $\begin{array}{l}\text { ROS of the } \\
\text { company }\end{array}$ & $\begin{array}{l}\text { Average national } \\
\text { industry ROS }\end{array}$ \\
\hline \multirow[t]{6}{*}{ CLUSTER I } & 9 & British & 0.08 & 0.10 \\
\hline & 10 & British & 0.12 & 0.10 \\
\hline & 11 & British & 0.12 & 0.10 \\
\hline & 12 & British & 0.08 & 0.10 \\
\hline & 13 & British & 0.10 & 0.10 \\
\hline & 20 & Dutch & 0.07 & 0.07 \\
\hline \multirow[t]{3}{*}{ CLUSTER II } & 14 & Dutch & 0.09 & 0.07 \\
\hline & 16 & Dutch & 0.05 & 0.07 \\
\hline & 19 & Dutch & missing & 0.07 \\
\hline \multirow[t]{3}{*}{ CLUSTER III } & 15 & Duteh & 0.13 & 0.07 \\
\hline & 17 & Dutch & missing & 0.07 \\
\hline & 18 & Dutch & -0.01 & 0.07 \\
\hline
\end{tabular}

Table 7.14: ROS per company per food \& drink cluster

Food \& drink cluster II contains three Dutch companies. Based on the analysis of the type of fit, companies 14 and 19 were expected to outperform company 16. When the ROS of the companies is examined, this indeed appears to be the case. Although ROS data for company 19 are missing, company 14 reported one of the highest ROS of the Dutch food \& drink sample. It appears that an HRM policy that theoretically is too advanced for all the other elements does not impede but indeed contribute to superior performance. Company 16 possesses an ROS that belongs to the lowest in the Dutch sample. Although it was hypothesized that this company may have implemented a different strategy than it formally stated, this is doubtful considering its performance. To increase their performance, they should either adapt the technology-HRM combination to the generic strategy and move out of the environment with an extreme drive to cost control or adapt their strategy to their competitive environment and to the HRM and production technology policies 
employed. The ROS for each of the companies in this cluster is summarized in Table 7. 74.

Finally, food \& drink cluster III comprises three Dutch firms. Company 15 was expected to outperform companies 17 and 18 that suffered from several misalignments. When the ROS for these companies is examined, this proposition is confirmed. Company 15 with a ROS of 0.13 is the best performer of the entire British and Dutch sample. Like company 14 in cluster 11 , this firm also invested more than theoretically required by the competitive environment and generic strategy in HRM. Additionally, their production technology also seemed to be too advanced. Also in this case, however, instead of constraining performance the additional investments seem to contribute to superior performance. Although performance data are missing for company 17 , the misalignment of various ellements in company 18 make it the worst performer in the industry with an ROS of -0.01 . This company can truly be considered 'stuck in the middle' (Porter, 1980) or classified as a reactor strategist (Miles \& Snow, 1978), since neither internal consistency among HRM and production technology exists, nor external consistency in meeting environmental requirements, nor any consistency with the generic strategy pursued. The results for this cluster are summarized in Table 7.14.

Besides performance differences within the clusters also differences between the clusters were investigated. No significant difference in ROS between the clusters could be detected, although cluster 1 , on average, has the highest ROS (0.1) and cluster 111 the lowest $(0.06)$. Cluster II ranks in between with an average ROS of 0.07 . When the subjective self-reports were evaluated, however, significant differences between the clusters do appear on all three measures. The companies in cluster $\|$ are significantly $(p=0.0356)$ more confident that their profitability is high compared to their national competitors than the companies in cluster I - that raniks second - and the companies in cluster III. Considering the Dutch companies in cluster II and III, this finding is supported by the average ROS for these clusters. The same result appears when profitability compared to last year is analyzed $(p=0.0882)$. When, however, profitability compared to foreign competitors is considered, the best performing cluster in terms of ROS - number - feels least secure about its profitability.

\section{Chemicals}

Of the two British companies that operate in chemical cluster 1 , company 1 was expected to outperform company 2. Company 2, similar to food \& drink company 18. suffered from various inconsistencies. Analysis of the ROS for both companies supports this hypothesis. On the one hand, company 1 obtained an ROS of 0.23 , the highest value in the entire chemical sample. This also indicates that the strategy implemented in this case must differ from the strategy formally stated. Company 2 . on the other hand, suffers from the worst performance in the British chemical 
sample with an ROS of 0.01 . This company can be considered 'stuck in the middle' (Porter, 1980) or pursuing a reactor strategy (Miles \& Snow, 1978), since it suffers from an inconsistent technology-HRM combination that is aligned to neither the generic strategy nor the competitive environment in any systematic way. Furthermore, its generic strategy does not meet the requirements posed by the competitive environment. The results for these companies are summarized in Table 7.15 .

Chemical cluster II consists of only one British firm that demonstrated a perfect alignment of all the elements investigated. Although its ROS cannot be compared to other companies operating under similar conditions, performance: with a ROS of 0.12 - is as expected, and equal to the British industry average. The results are summarized in Table 7.15.

\begin{tabular}{||l|l|l|c|c||}
\hline Chemicals & Company number & Notionality & $\begin{array}{l}\text { ROS per } \\
\text { company }\end{array}$ & $\begin{array}{l}\text { Average national } \\
\text { industry ROS }\end{array}$ \\
\hline \multirow{2}{*}{ CLUSTER I } & 1 & British & 0.23 & 0.12 \\
\cline { 2 - 5 } & 2 & British & 0.01 & 0.12 \\
\hline CLUSTER II & 3 & British & 0.12 & 0.12 \\
\hline CLUSTER III & 4 & Dutch & 0.01 & 0.02 \\
\cline { 2 - 5 } & 6 & Dutch & 0.03 & 0.02 \\
\hline \multirow{2}{*}{ CLUSTER N } & 8 & Dutch & 0.03 & 0.02 \\
\cline { 2 - 5 } & 5 & Dutch & 0.05 & 0.02 \\
\hline
\end{tabular}

Table 7.15: ROS per company per chemical cluster

Chuster Ill holds three Dutch firms that were all expected not to perform very well, although for company 8 the hypothesis was tentative due to missing data on the technological setting. The ROS for company 4 and $6,0.01$ and -0.03 , respectively, indeed suggest that these companies suffer from inferior performance. Company 8 , however, has a ROS of 0.03 , which is above the Dutch industry average. Apparently, this firm employs a production technology that fits the environment with a slight emphasis on a drive to cost control while at the same time maintaining enough flexibility to pursue a differentiation strategy. The ROS for each company in this cluster is summarized in Table 7.15 .

Chemical cluster IV comprises Dutch companies 5 and 7. Because company 5 had perfectly matched all the elements investigated, it was expected to outperform company 7, which invested more than required by strategy or competitive environment in advanced technology and possessed a questionable technology-HRM fit. The ROS for both companies, however, is equally high -0.05 
in both cases. So, like in food \& drink company 15 an additional investment in advanced technology leads to superior performance. Furthermore, the results of Chapter 6 on the limited impact of advanced manufacturing technologies in continuous process production seem confirmed. Companies that employ flexible continuous process production apparently perform well, even when traditionall personnel management is employed. The results for this cluster are also summarized in Table 7.15.

Finally, performance, in terms of ROS and a subjective self report on profitability, between the clusters was analyzed but no significant differences appeared. So, in the chemical industry the differences within clusters are larger than between clusters.

\subsection{Conclusion}

This chapter analyzes the performance implications of the profiles adopted by the companies that consist of six different types of fit: i) the fit between the generic strategy and the competitive environment, ii) the fit between the technological setting and strategy, iii) the fit between the technological setting and the competitive environment, iv) the fit between HRM and strategy, $v /$ the fit between HRM and the competitive environment and, finally, vil the fit between the technological setting and HRM. Performance is measured using questionnaire data on Return on Sales (ROS), calculated as the profit before taxes divided by sales.

In both industries, the hypothesis that companies which aligned the different elements to a perfectlly consistent profile would gain above average performance, is confirmed by our analysis. In the food \& drink industry four companies with a perfect fit - companies 10 and 11 in cluster 1 , company 14 in Cluster II and company 15 in Cluster II - gained above average performance. In the chemical industry, also four companies with perfect alignment - company 1 in cluster 1 , company 3 in cluster II and companies 5 and 7 in cluster IV - were detected. Striking about these results for both industries, however, is that three companies are included among the above average performers that 'over-invested' in production technology or HRM. Food \& drink company 14 employs true HRM while to match the generic strategy, technological setting and competitive environment it could suffice with traditional personnel management. Food \& drink company 15 employs true HRM and flexible comtinuous process production while also traditional HRM and any less sophisticated production technology would be sufficient. Finally, chemical company 7 implemented flexible continuous process production while it could meet the requirements posed by the environment and strategy with a less adwanced production system. This distinction detected in our sample is similar to two categories that Chakravarthy (1986) distinguishes when measuring the quality 
of a firm's transformation. He identifies 'adaptive specialization' and 'adaptive generalization". Adaptive specialization on the one hand, refers to the process of improving the goodness of fit in a given situation. This applies to all the companies with a perfect match in our sample. Adaptive generalization, on the other hand, refers to the investment in a surplus of 'slack resources', which enables the firm to improve its ability to adapt to changing conditions. This apparently is the case with the companies in our sample that "over-invested". Although, of course, by applying ROS as the performance measure only companies that successfully created and utilized these slack resources are recognized as such. Firms that are in the process of investing in technology and therefore suffer from worse performance in the year investigated, will not be detected. Besides the companies that performed above average, also two reactors (Miles \& Snow, 1978) or companies that are "stuck in the middle' (Porter, 1980), are identified. Food \& drink company 18 and chemical company 2 both suffer from internal inconsistencies which are neither matched to the strategy pursued nor to the competitive environment. Therefore, they suffer from inferior performance.

Although the results presented in this chapter are promising, they remain preliminary for three reasons. By way of conclusion, these are briefly indicated.

1. A serious limitation of the analysis is that no conclusions can be drawn about what percentage of performance is explained by the six types off fit investigated, or which type of fit contributes most or least to performance. The data set at this point is too limited to perform multivariate analysis.

2. Data on whether a stated strategy is actually implemented are not available. This was already mentioned in Chapter 3 on generic strategies and in Chapter 5 on HRM policies. It appears again in this chapter because of food \& drink company 16 and chemical company 1. For these companies it is expected that the generic strategy stated differs from the strategy implemented. The questionnaire employed needs improvement on this point and be able to establish a sounder strategic profile.

3. The measure of performance used, ROS, is too restricted and needs to move to a more multi-faceted measure that includes, apart from multiple measures of financial performance, non-financial data as well. As was mentioned in Section 7.1, the objectives companies pursue with their strategies are hardly ever limited to financial criteria. To measure the impact of strategy, performance measures should therefore also include a broader perspective. 


\section{CHAPTER 8}

\section{SUMMARY OF CONCLUSIONS AND FUTURE RESEARCH}

The objective of this study was to gain more insight into the relationship between the competitive environment, generic strategies and specific strategies regarding manufacturing technology and human resource management (HAM). This chapter summarizes the conclusions of the previous chapters and addresses the problems encountered while performing the analyses by discussing the validity of the questionnaire and future research. Section 8.1 presents a summary of the empirical results regarding the relationship between the competitive environment, generic strategies and specific manufacturing and HRM strategies. Section 8.2 summarizes the country differences between Great Britain and the Netherlands and thus explores whether organizations in one of the two nations have a competitive advantage over the other, while Section 8.3 presents a summary of the differences detected between the chemical and food \& drink industry. In Section 8.4 the question - as formulated in Chapter 3 - whether strategic groups within the industries are present is discussed. Section 8.5 then turns to the data collection instrument employed and discusses issues relating to the validity of the questionnaire. Finally, in Section 8.6 suggestions for future research are presented.

\subsection{Summary of empirical results}

As was mentioned in the Introduction of this book, the objective of this study was not to determine whether certain specific strategies are more important than others, but merely to study if and how parallel specific strategies link up with the chosen overall strategy. The results in that sense are encouraging, since organizations with coherent environment-generic strategy-specific strategy gestalts indeed perform better than those organizations where this coherence is lacking. However, before turning to the topic of which gestalts represent a coherent profile, the classification schemes used for the competitive environment, generic strategies and specific manufacturing and HRM strategies are summarized first.

The competitive environment (Chapter 3) is described in two dimensions that were derived by applying a PRINCALS analysis to a set of statements describing the environment of the companies. Dimension 1 portrays a continuum between a "drive to cost control" and a "drive to innovate" and refers to items that affect the 
intrinsic operations of the company. Dimension 2 represents a continuum between a "drive to sophisticated marketing" and a "drive to minimize the marketing effort" and thus relates to items that affect the necessity for well-developed marketing and sales activities.

The generic strategies (Chapter 3) are classified according to Porter (1980) in the Dutch sample and according to Miles \& Snow (1978) in Great Britain. In the Dutch sample of chemical and food \& drink companies, five generic strategies are detected: i) differentiation, ii) cost leadership, iii) differentiation focus, iv) cost focus and $v$ ) a combination strategy of differentiation, cost leadership and focus. The British chemical and food \& drink companies are characterized by two generic strategies: i) defenders and ii) analyzers.

The specific strategies regarding manufacturing technology (Chapter 4) are characterized by the degree of flexibility and integration expected to be achieved in the manufacturing function. In large batch and mass production this results in four categories of technological settings that represent a gliding scale from little to much flexibility and integration - synonymous to little and much investment in advanced manufacturing technologies: modified large batch and mass production, automated large batch and mass production, flexible large batch and mass production and, finally, innovative large batch and mass production. In continuous process production also four categories are distinguished which, however, represent opposite poles on this continuum. Limited investment in advanced manufacturing technologies has taken place in three categories: automated planning in continuous process production, automated design in continuous process production and automated continuous process production. On the opposite end of the continuum resides flexible continuous process production where a relatively higher level of flexibility and integration is assumed.

The specific strategies regarding HRM (Chapter 5) are classified by the level of strategic integration and decentralization. Four types of HRM strategies emerge: a 'true' HRM strategy which is integrated with the generic strategy pursued and decentralized to a lower level in the organization; an 'imposed' HRM strategy that is also integrated with the generic strategy pursued but implemented in a centralized manner; an "evolving" HRM strategy, where personnel policies are develaped at a decentralized level without being integrated with the generic strategy pursued; and, finally, a traditional personnel strategy without strategic integration and decentralization.

In Chapter 6 the manufacturing strategies are compared to the HRM strategies. To study the impact of advanced manufacturing technologies on the work organization - and thus the HRM strategy - the average changes in the production environment that the chemical and food \& drink companies perceive after the implementation of advanced manufacturing technologies, are used as a benchmark. 
To determine whether gestalts are coherent or incoherent, six different types of fit are examined (Chapter 7): i) the fit between the generic strategy and the competitive environment, ii) the fit between the technological setting and the generic strategy, iii) the fit between the technological setting and the competitive environment, iv) the fit between HRM and the generic strategy, v) the fit between HRM and the competitive environment and, finally, vil the fit between the technological setting and HRM. These different types of fit are then related to the performance - in terms of Return on Sales (ROS) - of the organization. The best performing caherent gestalts are presented in Table 8.1 for the food \& drink industry and in Table 8.2 for the chemical industry. The numbers of the companias correspond to a short company description in Appendix A.

\begin{tabular}{|c|c|c|}
\hline Competitive enwironment & Drive to cost contral & Drive to innovate \\
\hline $\begin{array}{l}\text { Drive to sophisticated } \\
\text { marketing }\end{array}$ & $\begin{array}{l}\text { Company number } 14 \text {; } \\
\text { combination strategy of } \\
\text { cost leadership. } \\
\text { differentiation and focus } \\
\text { automated planning in } \\
\text { continuous process } \\
\text { production } \\
\text { true HRM }\end{array}$ & $\begin{array}{l}\text { Companies number } 10 \text { \& } 11: \\
\text { * analyzer strategy } \\
\text { innovative large batich } \\
\text { and mass piroduction } \\
\text { evolving and true } \\
\text { HAM respectively }\end{array}$ \\
\hline $\begin{array}{l}\text { Drive to minimize the } \\
\text { marketing effort }\end{array}$ & $\begin{array}{l}\text { Company number } 15: \\
\text { * cost leadership strategy } \\
\text { flexible continuous } \\
\text { process production } \\
\text { true HAM }\end{array}$ & $\begin{array}{l}\text { No food \& drink companies } \\
\text { operate in this enviromment }\end{array}$ \\
\hline
\end{tabular}

Table 8.1: Best performing coherent gestalts in the food \& drink industry

\begin{tabular}{|c|c|c|}
\hline Competitive environment & Drive to cost controf & Drive to innowate \\
\hline $\begin{array}{l}\text { Drive to sophisticated } \\
\text { marketing }\end{array}$ & $\begin{array}{l}\text { Company number } 3 \text { : } \\
\text { * analyzer strategy } \\
\text { * innovative large batch and } \\
\text { mass production } \\
\text { true HRM }\end{array}$ & $\begin{array}{l}\text { No chemical companies } \\
\text { operate in this enwironment }\end{array}$ \\
\hline $\begin{array}{l}\text { Orive to minwize the } \\
\text { marketing effort }\end{array}$ & $\begin{array}{l}\text { Companies number } 5 \text { and } 7 \text { : } \\
\text { cost leadership and cost } \\
\text { focus strategies } \\
\text { respectively } \\
\text { automated and flexible } \\
\text { continuous process } \\
\text { production respectively } \\
\text { traditional persommel } \\
\text { management }\end{array}$ & $\begin{array}{l}\text { Company number } 1 \text { : } \\
\text { * defender strategy } \\
\text { tlexible continuous } \\
\text { process piroduction } \\
\text { Traditional personnel } \\
\text { management }\end{array}$ \\
\hline
\end{tabular}

Table 8.2: Best performing coherent gestalts in the chemical industry 
Although these results are not surprising and consistent with what theory would predict, they also contain some striking observations. First, a combination strategy of cost leadership, differentiation and focus only successfully appears in the food \& drink industry in a competitive environment with a drive to cost control and a drive to sophisticated marketing. The hypothesis that this combination strategy is only feasible when differentiation occurs through the creation of a perceived added value through marketing, seems confirmed by this result. A perceived - rather than real - added value is almost impossible to achieve in the chemical industry due to the importance of the technical specifications of the product. Furthermore, all the companies in the food \& drink industry pursue true HRM strategies even when based on the competitive environment, strategy and technological setting a less advanced form would suffice. Furthermore, company 15 utilizes flexible continuous process production while a less advanced manufacturing technology would also match the generic strategy and environmental conditions. "Over" investment also occurs once in the chemical industry, but now concerning the technological setting of company number 7. Flexible continuous process production is theoretically too advanced for the competitive environment, generic strategy and HRM strategy, but seems to contribute to better performance. A possible explanation for this phenomenon is that the implementation of advanced manufacturing technologies increased efficiency to such an extent that the cost incurred were offset. The question then, however, arises whether company number 5 will not be lagging behind in the future. Company number 3 in the chemical industry also seems out of place, but since it balances between a drive to cost control and a drive to innovate (Figure 7.2) it possesses a completely coherent gestalt that also allows a further movement in the direction of a drive to innovate. Finally chemical company number 1. The defender strategy presents a misfit with the competitive environment, technological setting and the HRM policy pursued. Because this company belongs to the best performers in the industry, it is assumed that in this case the strategy implemented differs from the strategy formally stated. This problem will be elaborated upon in Section 8.5.

Although due to the nature of the sample none of the results may be extrapolated to a larger whole, for the companies in our sample it can be concluded that superior performance is achieved by those organizations that are internally consistent and at the same time aligned to the competitive environment without losing sight of competition. Sun-Tzu's two-thousand year old wisdom quoted in the Introduction for them indeed holds:

"He who knows the enemy and himself, Will in a hundred battles not be in danger". 


\subsection{Summary of country differences between Great Britain and the Netherlands}

Two European countries were included in the analysis to explore potential differences between the organizations in Great Britain and the Netherlands. With respect to the relationships studied only a relatively limited number of significant differences appeared. The British and Dutch companies differ significantly on environmental dimension 1: the drive to innovate is much stronger in British than in Dutch organizations. Consistent with this finding the British companies invest more in advanced manufacturing technologies, such as CAD, CAM, Robots and FMS. These differences between the countries are, however, partly attributable to the nature of the sample. The British sample contains more large batch and mass production firms than the Dutch sample in which continuous process production is the dominant mode of production. Since the possibility to gain flexibillity and integration benefits by the implementation of advanced manufacturing technologies is larger in large batch and mass production than in continuous process production, this could also explain why advanced manufacturing technologies are implemented more in Great Britain. Furthermore, the British and Dutch companies in the sample differ in size. Since the British companies are in general larger than their Dutch counterparts, the investment in advanced manufacturing technologies could possibly also be attributed to differences in size. This, however, needs to be further investigated.

The specific strategy on which both countries were expected to differ most is the HRM strategy, since this is most strongly embedded in the institutional context of the countries. Analysis of the business systems and industrial relations in both countries indeed reveals that differences with respect to the content of HRM strategies exist. Because of the existence of societal effects on HRM practices, HRM strategies are examined at a level where the societal effect has lless direct impact. At this level - where HRM strategies are characterized by the degree of strategic integration and decentralization - no substantial differences between the type of HRM strategies are detected. Among the companies that practice traditional personnel management, however, the vast majority is Dutch.

Finally, a difference in the performance measure - Return on Sales (ROS) - is observed: the British companies posses a significantly higher ROS than their Dutch counterparts. This is aiso believed to be partly rooted in the financial-institutional context, especially since subjective performance measures do not indicate a significantly better performance of the British firms.

No differences, however, between Great Britain and the Netherlands are found when the nature of relationship between the competitive environment, generic strategies and specific manufacturing and HRM strategies is examined. Although the type of combinations differ between - and within - the countries, in each country coherent gestalts outperform incoherent combinations. So for the 
companies in this sample it can be concluded that being British or being Dutch does not automatically contribute to gaining a competitive advantage.

\subsection{Summary of industry differences between chemicals and food \& drinks}

Two industries were included in the sample to examine whether the relationship between the competitive environment, generic strategies and specific manufacturing and HRM strategies differs between the chemical and food \& drink industry. The main differencie between the industries can be found in the competitive environment they operate in. The food \& drink industry abtains a significantly higher score on environmental dimension 2 'the drive to sophisticated marketing'. This difference is a logical consequence of the characteristics of both industries (Chapter 3). The importance of sophisticated marketing is also reflected in the fact that a combination strategy of cost leadership, differentiation and focus is only found in the food \& drink industry. As was explained in Section 8.1, a simultaneous emphasis on differentiation and cost leadership is only feasible when differentiation is achieved through the creation of a perceived - rather than real added value, which can be attained in the food $\&$ drink industry.

Although the explanations behind the gestalts of competitive environment, generic and specific strategies differ, the fact that only coherence leads to superior performance does not differ over industries.

\subsection{Do strategic groups exist within the industries?}

In Chapter 3, clusters within the chemical and food \& drink industry were established to examine the relationship between competitive environment, generic strategies and specific manufacturing and HRM strategies within industries. Since the different clusters within both industries showed considerable variation in their perception of the competitive environment, the question arose whether these clusters could be viewed as strategic groups.

Strategic groups are defined as groups of firms in an industry that pursue similar strategies (Porter, 1980) that are tied to similar resource commitments (Coo) \& Schendel, 1987). Furthermore they are separated from other groupings by mobility, entry and exit barriers (Mascarenhas \& Aaker, 1989). The different food \& drink and chemical clusters labeled with their strategy-technology-HRM pairs in their respective competitive environments are presented in Figure 8.1 . The discussion on whether strategic groups are present can, however, remain but tentative since no information on mobility, entry or exit barriers is available. 


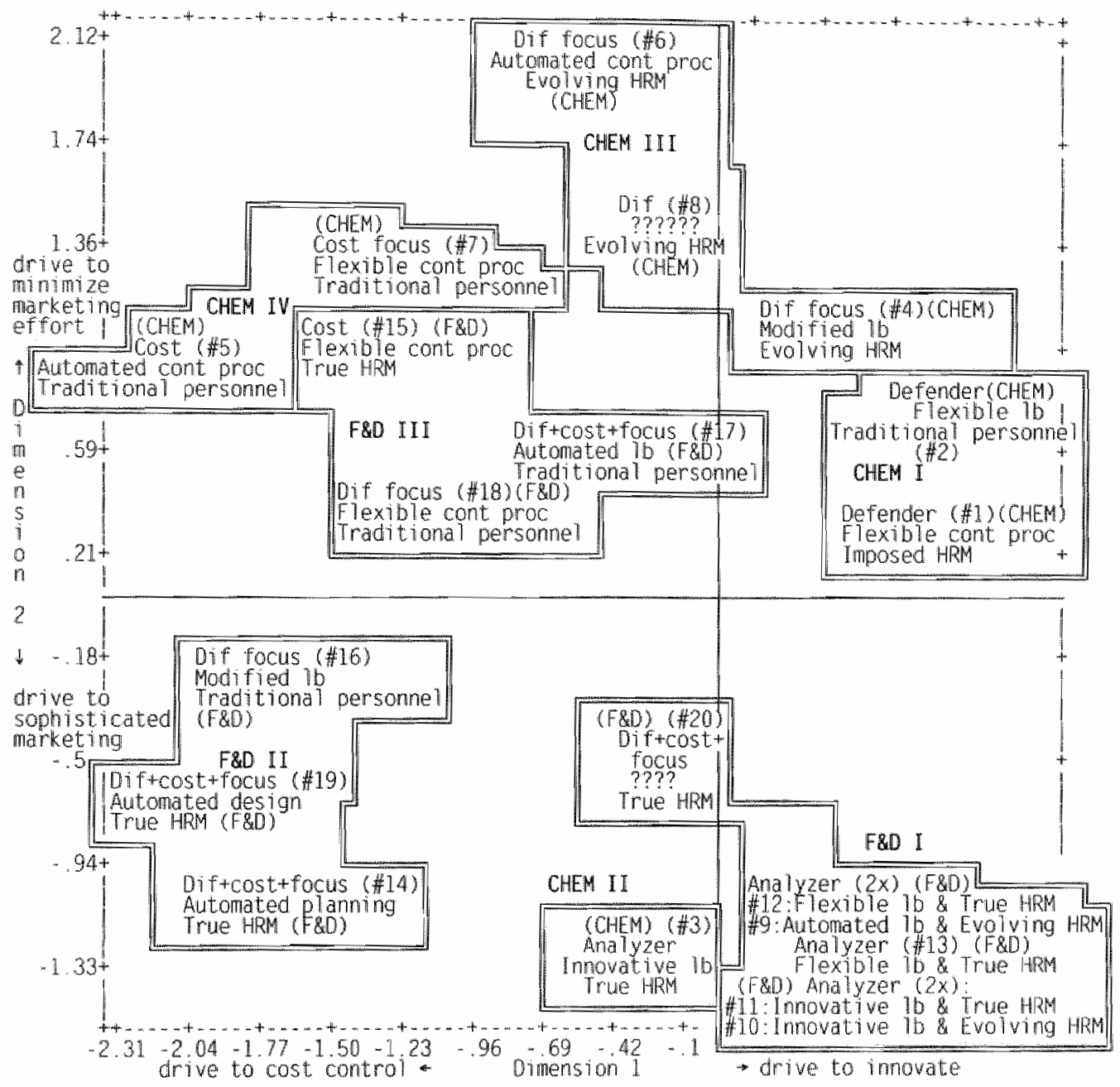

Chemicals

Food \& Drinks

Differentiation

Differentiation focus

Combination of differentiation, cost leadership and focus

Cost leadership

Continuous process production

Large batch and mass production

Traditional personnel managerment

Figure 8.1: Food \& drink and chemical clusters labeled with strategy-technologyHRM pairs in their respective competitive environments 
In the food \& drink industry three clusters were distinguished. Although cluster I consists of firms that all pursue similar strategies, their resource allocation to the manufacturing function differs. Therefore it is suspected that this cluster contains two strategic groups: companies number 10 and 11 on the one hand and companies 9, 12, and 13 on the other. Companies number 10 and 11 employ manufacturing strategies that are more advanced and they both perform significantly better than the other companies. Althougth a difference in performance in itself is no criterium to classify strategic groups, these two companies might have created entry barriers through the combination of aggressive advertising and the creation of a brand name. Cluster II consist of two firms - number 14 and 19. that operate with similar strategies and similar resource allocation patterns and are thus expected to belong to the same strategic group. Company number 16 , however, pursues a different generic and a different HRM strategy. Finally, cluster III contains three companies that have very different profiles. These companies are obviously not expected to belong to the same strategic group.

In the chemical industry, four clusters were distinguished. Cluster I contains two firms that at first glance appear very similar. It was concluded however in Chapter 7 that the generic strategy stated of company number 1 is suspected to differ from the strategy implemented. If this is the case these companies do not belong to the same strategic group. Cluster II only consists of one firm. This makes any canclusions on strategic groups, of course, impossible. The three firms in Cluster III all have similar generic strategies, and although there is a significant performance difference between company 4 and 6 , these firms could belong to the same strategic group. Finally, cluster IV. Although the generic and HRM strategy is simillar, a difference exists with respect to the manufacturing strategy. Since resource allocations in this area differ, also these companies are not expected to be positioned in the same strategic group.

So, on the basis of the information available not many strategic groups exist arnong the companies in our sample: three in the food \& drink industry and one in the chemical industry.

\subsection{Validity of the questionnaire}

As was discussed in Chapter 2, the International Organizational Observatory (IOO) was a pioneer attempt at building a European-wide data base on the functioning of organizations. Since the questionnaire was thus not developed with this specific research project in mind, several problems in the measurement of concepts were encountered. These problems - which were addressed in the previous chapters will be summarized in this section. Also suggestions for improvement of the questionnaire are provided. 
In Chapter 3 generic strategies were measured using Porter's (1980) and Miles \& Snow's typologies. To determine which strategles the companies pursued, the Dutch companies were asked whether they emphasized cost, quality or both and/or focused on a specific segment (Appendix B). The British companies were asked to state their generic strategy, after which the British researchers classified them on the basis of a list of key features derived from Miles \& Snow's (1978) work. In this approach a risk exists that the strategy stated by the companies differs from the strategy implemented las is suspected in chemical company number 1). Although this risk can never be completely avoided when questionnaires are used, the risk can be minimized by formulating the question in such a way that the temptation to provide a desired answer is minimized. A suggestion would be to develop a list of statements based on Porter's (1980) and Miles \& Snow's (1978) work for which the companies determine on a scale from 1 (incorrect) to 4 (correct) how they rank on this statement. The advantages of such an approach are that i) "wishful" thinking is minimized because of the increased number of diverse statements and, ii) potential combinations between features that are not included in the original typologies could be detected.

In Chapter 4 the implementation of advanced manufacturing technologies was discussed. It was assumed in this chapter that increased implementation of advanced manufacturing technologies resulted in increased flexibility and integration of the manufacturing function. However, to determine the real impact of the implementation of advanced manufacturing technologies additional information is necessary on i) the objectives to be realized before implementation, ii) whether these objectives are indeed realized at the present time, iii) whether the manufacturing system is fully developed or whether improvements are still being made and iv) which performance measures are used to determine a potential increase in flexibility and integration (if these were the objectives).

In Chapter 5 HRM strategies were analyzed. There are, however, several improvements to be made in the questionnaire employed to analyze more in depth whether HRM strategies rather than traditional personnel management is pursued in the companies. First, questions on the content of HRM need to be extended that specifically address the HRM components of recruitment and selection. performance appraisal and compensation and tiraining and development. Second, questions need to be included on the level of strategic integration, such as whether the personnel manager is a member of the management team, whether he is involved in developing the generic strategy for the division or business unit and whether he specifically incorporates the objectives of the generic strategy into an HRM strategy. Finally, the integration of the different HRM components needs to be addressed since this is - besides strategic integration and decentralization - also an important part of the definition of an HRM strategy compared to traditional personnel management. 
Finally in Chapter 7, performance implications were analyzed. The performance measure employed is, however, too restricted. First, it was measured over a one year time period only. This entails the risk that the result is influenced by incidental external factors beyond the control of the company. Second, to measure the impact of strategies performance measures should be extended beyond financial criteria. So, ideally a performance measure should be a multi-year multi-faceted measure that includes, besides multiple measures of financial performance, also non-financial data. The collection of financial data, however. proved to be very difficult due to the nature of the sample. Furthermore it was argued in Chapter 7 that the existence of country and industry differences complicates the interpretation of financial measures. Therefore it is suggested to create a performance index similar to that of Govindarajan 11988), Govindarajan \& Fisher (1990) and Conant, Mokwa \& Rajan Varadarajan (1990). This would imply that respondents rate performance items, such as profit or market share, on two scales: 1) a Likert-scale ranging from 'significantly below average' to 'significantly above average" and 2) a Likert scale ranging from "not important' to extremely important'. Using the data on importance as weights, a performance index can then be calculated. To have some check on the validity of this self-report, "objective" data on profit and sales should remain part the performance questions.

\subsection{Future research}

In Chapter 2 the different parts of the 100 questionnaire were described and it was explained why only a limited number of topics are included in this study. Since, however, data on these topics are collected and available, the present analysis can be extended to organization structure, planning and control systems and information systems. An interesting research question in this context would be whether the coherent gestalts remain coherent when the decisions regarding organization structure, planning and control and information systems are incorporated in the analysis. Furthermore the current analysis can be extended to France, since also the French data are now available.

Since the relationships could now only be studied in a small sample. the classification schemes developed to position the companies with regard to the competitive environment and specific manufacturing and HRM strategies as well as the proposition that coherent combinations outperform incoherent gestalts, need to be tested in a larger sample.

One of the most promising avenues of future research is provided by the 100. Based on experience with the data collection instrument in this study and in other studies by other member countries, an improved questionnaire is currently developed. This new instrument focuses on specific research questions, and thus 
loses the general nature it now possesses, and is considerably shorter to reduce the interview burden put on companies. Furthermore questions are equal in all the countries that agree to participate in the analysis of a particular research question, which enables the more rigorously testing of the research questions in a larger sample. 


\section{APPENDIX A}

\section{CHARACTERISTIICS OF BRITISH AND DUTCH COMPANIES IN THE CHEMICAL AND FOOD \& DRINK SAMPLE}

\begin{tabular}{|c|c|c|c|c|c|}
\hline Nurribuer & Nationality & industry & $\begin{array}{l}\text { Size in } \\
\text { number of employees }\end{array}$ & Type of product & $\begin{array}{l}\text { Main } \\
\text { target } \\
\text { market }\end{array}$ \\
\hline 1 & British & Chemicats & 25,800 & $\begin{array}{l}\text { Bulk \& specialty } \\
\text { chemicals }\end{array}$ & Industrial \\
\hline 2 & British & Chemicals & 3,061 & Bulk chemicals & Consumer \\
\hline 3 & British & Chemicals & 1,100 & $\begin{array}{l}\text { Bulk speciality } \\
\text { chemicals }\end{array}$ & Consumer \\
\hline 4 & Dutch & Chemicals & 308 & $\begin{array}{l}\text { Specialty } \\
\text { chemicals }\end{array}$ & Industrial \\
\hline 5 & Dutch & Chemicals & $\begin{array}{l}\text { missing for company } \\
25,000 \text { for entire } \\
\text { group }\end{array}$ & Bulk chemicals & Industrial \\
\hline 6 & Dutch & Chemicats & 161 & $\begin{array}{l}\text { Butk \& specialty } \\
\text { chemicals }\end{array}$ & Industrial \\
\hline 7 & Dutch & Chemicals & 270 & Bulk chemicals & Industrial \\
\hline 8 & Dutch & Chemicals & 1,950 & Bulk chemicals & Consumer \\
\hline 9 & Britisith & Food \& drinks & 744 & Specialty teas: & Consumer \\
\hline 10 & British & Food \& drinks & 1,723 & $\begin{array}{l}\text { Alcoholic \& non- } \\
\text { alcoholic } \\
\text { beverages }\end{array}$ & Consumer \\
\hline 11 & British & Food \& drinks & 12,000 & Confectionery & Consumer \\
\hline 12 & British & Food \& drinks & 6,001 & Frozen foods & Consumer \\
\hline 13 & British & Food \& drinks & 2,524 & Confectionery & Consumer \\
\hline 14 & Dutch & Food \& drinks & 434 & $\begin{array}{l}\text { Alcoholic \& non- } \\
\text { alcoholic } \\
\text { beveragles }\end{array}$ & Consumer \\
\hline 15 & Dutchlu & Food \& drinks & 1.270 & $\begin{array}{l}\text { Basic food } \\
\text { product in bulk }\end{array}$ & Consumer \\
\hline 16 & Dutch & Food \& drinks & 162 & $\begin{array}{l}\text { Frozen potato } \\
\text { products }\end{array}$ & Consumer \\
\hline 17 & Dutch & Food \& drinks & 360 & Dairy products & Consiumer \\
\hline$\pi 8$ & Dutch & Food \& driniks & $\begin{array}{l}\text { missing for company } \\
7,077 \text { for entire } \\
\text { group }\end{array}$ & Dairy products & Consumer \\
\hline 19 & Dutch & Food \& drinks & 100 & Dairy products & Consumer \\
\hline 20 & Dutch & Food \& drinks & 1,100 & Confectionery & Consumer \\
\hline
\end{tabular}




\section{APPENDIX B}

\section{QUESTIONNAIRE ITEMS USED IN ANALYSES}

\section{B. 1 The Netherlands}

\section{B.1.1 Competitive environment: the Netherlands}

1. Wanneer $U$ de voornaamste sector waarin de onderneming opereert en de belangrijkste produkttijn als referentiekader neemt, welke van de volgende beweringen geven dan een beschrijving van de concurrentieomgeving waarin de onderneming en haar naaste concurrenten opereert?

Gebruik hiervoor de volgende schaal van 1 tot en met 4, waarbij:

$1=$ de bewering geeft een uiterst correcte beschrijving van de concurrentieomgeving

$4=$ de bewering geeft geen correcte beschrijving van de concurrentieomgeving

1.1 De merknaam is een bepalend element in het inkoopproces van klanten

1.2 De klanten krijgen te maken met hoge kosten indien zij zich tot een andere leverancier dan ons bedrijf wendlen

1.3 Toetreding tot sommige distributiekanalen is moeilijk

1.4 Schaalvergrating in de produktie leidt tot een aanzienlijke verlaging van de gemiddelde kosten per eenheid produkt

1.5 Het bezitten wan patenten op de technologie van het produkt is wit concurrentie oogpunt belangrijk

1.6 Een gunstige ligging van produktie enfof verkoop faciliteiten is uit concurrentie oogpunt belangrijk

1.7 De sector wordt sterk gesubsidieerd door de overheid

1.8 In de sector treedt slechts beperkte groei op, waardoor het slechts in beperkte mate mogelijk is om nieuwe concurrenten te laten toetreden zonder dat dit gevolgen heeft woor de werkopen en economische resultaten van al bestaande bedrijuen

1.9 Het produkt dat door ans bij onze voornaamste leverancier wordt gekocht is bepalend woor de kwaliteit van het eindprodukt dat wij leveren

1.10 De sector wordt gekenmerkt door een agressief gebruik van reclame

1.11 De concurrenten zijn niet erg gediversificeerd

1.12 De ondernemingen in de sector hebben recent hun produktiecapaciteit sterk vergroot

1.13 De concurrentie groeit door een toename van substitueerbare produkten

1.14 Ons produkt beinvloedt in hoge mate de kwaliteit van het produkt/de dienst van onze klant

1.15 De klant heeft gedetailleerde informatie over de vraag en de prijzen in de markt

1.16 Het makkelijk kunnen beschikken over grondstoffen, is uit concurrentie oogpunt belangrijk

1.17 Het wordt andere bedrijven bemoeilijkt om tot de sector toe te treden, daar de al aanwezige bedrijven over aanzienlijk hulpbronnen beschikken (bijv. sterke liquiditeit, ongebruikte tegoeden, overschot aan produktie-capaciteit, grote inwloed op de distributiekanalen en op hun klanten)

1.18 Om te kunnen opereren in deze sector is het noodzakelijk deel uit te maken van een nationale groep of een netwerk van bedrijuen

1.19 Om te kunnen opereren in de sector is het noodzakelijk deel uit te maken van een multinationale groep of een netwerk van bedrijven verdeeld over diverse landen 


\section{B.1.2 Generic strategy: the Netherlands}

1. Is de strategie formeel in een plan vastgelegd?

2. Maakt de onderneming:

- een strategisch plan op andernemingsniveau

- een strategisch plan op business unit niveau

- een strategisch plan op functioneel niveau (bijvoorbeeld cen strategisch plan voor marketing)

3. Wordt er in de onderneming gebruikt gemaakt van een van de volgende concepten? produkt levenscycli technologische levenscycli portfolio matrices om de strategische positie van de door de onderneming gevoerde produkten te bepalen

4. Verzamelt $U$ systematisch informatie over:

concurrenten

klanten

afzetmarkten

leveranciers

5. Hoe wordt deze informatie verzameld?

voornamelijk door interne staf

voornamelijk door externe instanties

6. Voor Uw belangrijkste produkt lijnen, volgt $U$ voornamelijk een strategie van kosten leiderschap of van leiderschap op het gebied van kwaliteit?

7. Richt $U$ zich op een specifiek segment in de markt?

\section{B.1.3 Manufacturing technology and innovation: the Netherlands}

\section{PRODUCTION SYSTEM: the Netherlands}

1. Geef woor onderstaande beweringen aan in hoeverre deze een correcte beschrijving geven van de gebruikte produktiesystemen.

Gebruik hiervoor een schaal van $1 \mathrm{t} / \mathrm{m} 4$ waarbij:

1 = Een correcte omschrijving van de activiteiten, en

$4=$ Geen correcte beschrijving van de activiteiten.

1.1. De produkten worden alleen geproduceerd op basis van specificaties van eén klant of een kleine groep van klanten.

1.2 De produkten worden alleen in kleine series (500 stuks of minder) geproduceerd

1.3. De produkten worden in grotere hoeveelheden geproduceerd, maar bestaan zowel uit gestandaardiseerde componenten als componenten vervaardigd op bestelling van de klant.

1.4. De produkten worden in zeer grote series of in massaproduktie geproduceerd. Het produkt wordt niet regelmatig veranderd.

1.5. De produkten worden in zeer grote series of in massaproduktie geproduceerd. Toch worden frequent nieuwe produkten geïntroduceerd.

1.6. De produktie vindt plaats in een continue proces. 
2. Geef in onderstaand schema bij elke mogelijke automatiseringsmethode van de ontwerp en produktie functie aan, welk stadium van ontwikkeling is bereikt. $|x|$

\begin{tabular}{|c|c|c|c|c|}
\hline & & Niet in gebruik & $\begin{array}{l}\text { Alleen als } \\
\text { experiment }\end{array}$ & Wordt gebruikt \\
\hline 1. & $\mathrm{CAD}$ & & & \\
\hline 2. & CAM & & & \\
\hline 3. & CAE & & & \\
\hline 4. & MRP & & & \\
\hline 5. & CAPP & & & \\
\hline 6. & Robots & & & \\
\hline 7. & FMS & & & \\
\hline 8. & $\begin{array}{l}\mathrm{CNC}- \\
\text { machines }\end{array}$ & & & \\
\hline 9. & CPS & & & \\
\hline
\end{tabular}

1. CAD (Computer Alided Design): een informatiesysteem ter ondersteuning van werkzaamheden op het gebied van ontwerp, modelleren en archiveren.

2. CAM (Computer Aided Manufacturing): een informatiesysteem dat op geintegreerde wijze de machines in gebruik stuurt en beheerst.

3. CAE (Computer Aided Engineering): een informatiesysteem ter ondersteuning wan ontwerp berekeningen en functionele analyses van onderdelen en componenten.

4. MRP (Material Requirement Planning): een informatiesysteem ter ondersteuning van de planning van materialen.

5. CAPP (Computer Aided Process Planning): een informatiesysteem gericht op het definiëren van produktiemethoden met betrekking tot produktiecycli, werkinstructies en gebruik van machines.

6. Robot: automatisering van enkele fasen van produktie. Bijvoorbeeld een robot voor hat lakproces, het soldeerproces, het monteren etc.

7. FMS (Flexible Manufacturing Systems): een combinatie van CNC machines (zie 8 ) of andere machines of robots, geïntegreerd in een flexibel gestuurd systeem.

8. CNC machines (Computer Numerically Controlied Machines): machine gestuurd door een computer of andere machine met geheugen die geprogrammeerd kan worden.

\section{DEVELOPMENTS IN THE PRODUCTION ENVIRONMENT: the Netherlands}

3. Wanneer $U$ de actuele ontwikkelingen in de produktietechnologie als referentiekader neemt, geef dan de mate aan waarin de volgende beweringen op Uw onderneming van toepassing zijn.

Maak hierbij gebruik wan een schaal van $1 \mathrm{t} / \mathrm{m} 4$ waarbij:

$1=$ Een correcte beschrijving, en

$4=$ Niet van toepassing is.

3.1 Wij produceren steeds meer verschillende produlkten.

3.2 Het aantal verschillende ontwerp-en produktie varianten neemt toe.

3.3 De produkten lijken steeds meer op elkaar (standaardisatie). 
3.4 De tijd tussen het eerste idee voor een nieuw produkt en het moment waarop dit klaar is om in produktie te worden genomen wordt steeds langer.

3.5 Het werk in uitvoering en de voorraden materiaal en eindprodukt zijn aanzienlijk verminderd.

3.6 De gemiddelde serie-grootte wordt groter.

3.7 De produktiefasen zijn onderling nauwer met elkaar verbonden lorganisatorisch en/of technischl.

3.8 Bij ontwerp en ontwikkeling zijn in verhouding steeds meer medewerkers betrokken (in vergelijking tot produktiel.

3.9 Het aantal werknemers dat zich uitsluitend bezig houdt met de planning en tijdsprogrammering van het produktieproces, alsmede met de personeelsplanning en de controle ap de het werk in uitvoering is toegenomen.

3.10 De beheersing van de stroom van materialen, onderdelen, componenten en halffabrikaten is gedecentraliseerd naar werkgroepen of stations (bijv. 'just-in-time' systemenl.

3.11 Er is meer tijd nodig om machines in te stellen en gereed te maken voor produktie.

3.12 Er windt een steeds verdergaande specialisatie van arbeidskrachten plaats zowel op uitvoerend als op hoger geschoold niveau.

3.13 De produkten zijn technisch zodanig complex geworden dat een grote specialistische technische kennis met betrekking tot de ontwikkeling, het ontwerp en het produkt noodzakelijk is geworden. Hierdoor wordt steeds meer een beroep op derden gedaan (subcontracting).

\section{B.1.4 Personnel Management/HRM: the Netherlands}

\section{RECRUITMENT AND SELECTION: the Netherlands}

1. Welke middelen worden gebruikt om nieuw personeel te werven?

Gebruik hiervoor de volgende indeling:

$0=$ dit middel wordt niet gebruikt

$1=$ dit middel wordt soms gebruikt

2 = dit middel wordt constant gebruikt

1. Intern zoeken naar kandidaten

2. Het arbeidsbureau

3. Advertenties in de nationale pers

4. Advertenties in de regionale pers

5. Consultancy en headhunter bureaus

6. Recrutering op scholen en universiteiten

7. Persoonlijke aanbeveling

8. Overig

2. Geef in het onderstaande schema het belang van de genoemde selectiemethodes aan. Gebruik daarbij de volgende schaal.

$0=$ methode wordt niet gebruikt

1 methode wordt soms gebruikt

$2=$ methode wordt constant gebruikt

1. Individuele gesprekken

2. Groepsgesprekken

3. Psychologische testen

4. Grafologie 
5. Panel discussies

6. Assessment center

7. Overig (specificeren)

3. Hoe wordt nieuw personeel ingewerkt ?

\begin{tabular}{|c|c|c|c|c|c|}
\hline & & Management & $\begin{array}{l}\text { Miodle } \\
\text { management }\end{array}$ & $\begin{array}{l}\text { Overige } \\
\text { werknemers }\end{array}$ & $\begin{array}{l}\text { Produktie } \\
\text { werknemers }\end{array}$ \\
\hline 1. & $\begin{array}{l}\text { Geen specifieke } \\
\text { inwerk procedure }\end{array}$ & & & & \\
\hline 2. & $\begin{array}{l}\text { Een rotatie } \\
\text { programma }\end{array}$ & & & & \\
\hline 3. & $\begin{array}{l}\text { Meelopen met } \\
\text { ervaren personeel }\end{array}$ & & & & \\
\hline 4. & $\begin{array}{l}\text { Training en } \\
\text { opleiding }\end{array}$ & & & & \\
\hline 5. & $\begin{array}{l}\text { Formele } \\
\text { gesprekken ter } \\
\text { oriëntatie }\end{array}$ & & & & \\
\hline 6. & Overig: & & & & \\
\hline
\end{tabular}

PERFORMANCE APPRAISAL AND COMPENSATION: the Netherlands

4. Bestaat eir een formeel loopbaanplan ? S.V.P. invullen per categorie werknemers.

\begin{tabular}{||l|l|l|l|l|}
\hline & Management & $\begin{array}{l}\text { Middle } \\
\text { management }\end{array}$ & $\begin{array}{l}\text { Overige } \\
\text { werknemers }\end{array}$ & $\begin{array}{l}\text { Produktie } \\
\text { werknemers }\end{array}$ \\
\hline 1. Nee & & & & \\
\hline 2. $\begin{array}{l}\text { Ja, voornamelijk } \\
\text { per functie of } \\
\text { specialisme }\end{array}$ & $\begin{array}{l}\text { Ja. voornamelijk } \\
\text { tussen functie } \\
\text { gebieden en } \\
\text { generalistische } \\
\text { functies }\end{array}$ & & & \\
\hline 3. & & & \\
\hline
\end{tabular}

5. Welke percentage van de managers, middle managers, overige werknemers en produktie werknemers ontvangt salaris dat (woor een deel) gekoppeld is aan behaalde resultaten? 
6. Van welke van de volgende extra faciliteiten kan het personeel gebruik makem ?

\begin{tabular}{|c|c|c|c|c|c|}
\hline & & Management & $\begin{array}{l}\text { Middle } \\
\text { management }\end{array}$ & $\begin{array}{l}\text { Overige } \\
\text { werknemers }\end{array}$ & $\begin{array}{l}\text { Produktie } \\
\text { werknemers }\end{array}$ \\
\hline 1. & Maaltijden & & & & \\
\hline 2. & Sportfacilliteiten & & & & \\
\hline 3. & $\begin{array}{l}\text { Kopen bij de } \\
\text { onderneming }\end{array}$ & & & & \\
\hline 4. & Verzekeringen & & & & \\
\hline 5. & $\begin{array}{l}\text { Pensioen } \\
\text { voorzieningen }\end{array}$ & & & & \\
\hline 6. & $\begin{array}{l}\text { Faciliteiten als } \\
\text { gratis cursussen, } \\
\text { conterenties over } \\
\text { andere produkten }\end{array}$ & & & & \\
\hline 7. & $\begin{array}{l}\text { Financiering } \\
\text { faciliteiten, zoals } \\
\text { leningen }\end{array}$ & & & & \\
\hline 8. & Bedrijfsauto & & & & \\
\hline 9. & Bedrijfswoning & & & & \\
\hline 10 & $\begin{array}{l}\text { Aandelen van de } \\
\text { onderneming }\end{array}$ & & & & \\
\hline 11. & Aandelen opties & & & & \\
\hline 12. & Overig: & & & & \\
\hline
\end{tabular}

\section{TRAINING AND DEVELOPMENT: the Netherlands}

7. Wordt de behoefte aan training van thet personeell systematisch geanalyseerd?

- NEE

- IA

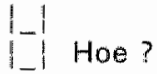

\section{B.1.5 Performance: the Netherlands}

1. Wat bedroeg Uw omzet in 1991?

2. Wat bedroeg in 1991 de winst/verlies (winst voor belastingl?

3. De winstgevendheid van de onderneming is: 


\begin{tabular}{|l|l|l|l|}
\hline & \multicolumn{2}{|l|}{$\begin{array}{l}\text { Vergeleken met } \\
\text { soortgelike/concurrende bedrijuen in: }\end{array}$} & Vergeleken met vorig jaar \\
\hline & Nederland & Buitenland & \\
\hline Veel slechter & & & \\
\hline Slechter & & & \\
\hline Gelijk & & & \\
\hline Beter & & & \\
\hline Veel beter & & & \\
\hline
\end{tabular}

\section{B.2 Great Britain}

\section{B.2.1 Competitive environment: Great Britain}

1. How would you characterize the competitive environment of the organization? 1 =incorrect description and $4=$ correct description

1.1 The brand name is an important element in the buying process of clients

1.2 Clients face high switching cost when they consider changing suppliers

1.3 There are obvious difficulties in getting access to some distribution channels

1.4 Economies of scale in production can be obtained

1.5. The possession of patents is important

1.6 A favourable location of production plants and/or sales facilities is important

1.7 Large government subsidies are a feature of this sector

1.8 The sector has a limited growth rate, which makes it difficult to absorb a new competitor without an adverse affect on the sales and trading results

1.9 The products we buy from our supplier determine the quality of the product we manufacture

1.10 Fierce advertising battles are a feature of this sector

1.11 The competitors in this sector are not highly diversified

1.12 Companies in this sector have recently increased their production capacity considerably

1.13 Competition from producers of substitutes of our products increases

1.14 Our product has a strong influence on the quality of our customer's product or service

1.15. The customer has detailed information on demand and market prices

1.16 Easy access to raw materials is important

1.17 In this sector, companies generally are in a strong position to withstand a new competitor

1.18 To operate in this sector it is essential to be able to call on the combined resources of a national group or network of companies

1.19 To operate in this sector it is essential to be able to call on the combined resources of a multinational group or network of companies located in different companies

\section{B.2.2 Generic strategy: Great Britain}

1. Do you draw up a formal strategic plan?

for the whole arganization

for the strategic business unit level

for each functional area 
2. What part do the following conceptual tools play in the strategy planning process? product life cycle

technology life cycle

portfolio matrices

3. What systematic data do you gather on:

competitors

customers

suppliers

general market or economic trends

4. What is the major source of this data?

internall only

publically available external data

commissioned studies

a mix

trade associations

5. Is this data analyzed on a regular basis?

6. What is you current strategy?

The answers of the companies were classified by the British researchers according to the main characteristics which Miles \& Snow (1978) mention for each of the strategy types.

\section{B.2.3 Manufacturing technology and innovation: Great Britain}

\section{PRODUCTION SYSTEM: Great Britain}

1. How would you characterize your organization's primary manufacturing technology?

1.1 Output is individually produced to the specification of an individual or small groups of customers

1.2 Output is produced in batches of 500 or less

1.3 Output is produced in larger batches but they tend to be modular, consisting of both standardized components and components produced for customers specification

1.4 Output is produced in very large batches or on mass production basis and the products change very little over time

1.5 Output is produced in very large batches or on a mass production basis but new products are often brought out

1.6 Output is for gaseous, viscous or solids and is produced using continuous process technology

2. To what extent do you use design aryd development tools and systems such as:

\subsection{Computer aided design}

2.2 Computer aided manufacturing

2.3 Computer aided engineering

2.4 Material requirement planning 
2.5 Computer aided process planning

2.6 Robotics

2.7 Flexible manufacturing systems

2.8 Numerically controlled machines

2.9 Flow process computers

\section{DEVELOPMENTS IN THE PRODUCTION ENVIRONMENT: Great Britain}

3. Given the current state of production technologies how do the following statements apply to your organization?

$1=$ incorrect description

$5=$ correct description

3.1 The number of products is increasing

3.2 The number of variants from standard is increasing

3.3 Products are becoming more standardized

3.4 The time between the initial idea for new products and when they enter production is becoming longer

3.5 Work in progress and stocks of materials are being reduced

3.6 Stocks of finished goads are being reduced

3.7 Batch size is increasing

3.8 The stages of the production process are becoming more closely integrated (from either the organizational or technical point of view)

3.9 There is a steady increase in the number of people involved in the design and development compared with numbers involved in production

3.10 There is steady increase in the number of people inwalved in planning and scheduling the production process compared with numbers involved in production

3.11 The management of materials, components and work in progress is becoming decentralized to work stations/groups

3.12 Plant and equipment is being used more intensively

3.13 The variety and diversity of skills needed to produce output is increasing

3.14 The previous statement has been largely resolved by subcontracting specific tasks

\section{B.2.4 Personnel management/HRM: Great Britain}

\section{RECRUITMENT AND SELECTION: Great Britain}

1. What methods do you use to recruit each grade of employee?

1. Job centers

2. Personal recommendation

3. Recruitment consultancies

4. Other

2. What kinds of assessments methods does your organization use when selecting the different grades of staff?
1. Interviews
2. References
3. Psychometric tests
4. Biodata
5. Graphology
6. Other 
3. What methods does your organization use when introducing new employees to the company and their jobs?
1. Unprogrammed and unassisted
2. Programmed
3. Ad-hoc
4. Mentoring
5. Formal monitoring and vocational guidance
6. Company brochure
7. Other

\section{PERFORMANCE APPRAISAL AND COMPENSATION: Great Britain}

4. To what extent are career paths formalized in the different grades of staff?

$1=$ not formalized to $5=$ formalized

5. What percentage of employees receive performance rellated pay?

6. What other benefits do you offer your employees?
1. Sports club
2. Company shop
3. Discounts
4. Insurance
5. Pension
6. Company loans
7. Private health
8. Loans
9. Other

\section{TRAINING AND DEVELOPMENT: Great Britain}

7. Do you systematically analyze the training needs of your employees?
If yes, how?
1. Training audits
2. Performance appraisals
3. Employee requests.
4. Other

\section{STRATEGIC INTEGRATION: Great Britain}

8. Was the personnel department involved in the development of a HRM or personnel strategy from the outset?

9. Was this strategy formally written down?

\section{DECENTRALIZATION: Great Britain}

10. Who is primarily responsible for the recruitment of different grades of employees?
1. Senior management
2. Personnel department
3. Line management 

4. First line supervisors
5. Other

11. Who is primarily responsible for regulating employee departures of different grades of employees?

1. Senior mamagement.

2. Personnel department

3. Line management:

4. First line supervisors

5. Other

12. Who has overall responsibility for career development policies?

1. Senior management

2. Personnel department

3. Line management

4. First line supervisors

5. Other

13. Who has overall responsibility for training?

1. Senior management

2. Personmel department

3. Line management

4. First line supervisors

5. Other

\section{B.2.5 Performance: Great Britain}

1. Profit before tax

2. Sales

3. How does your organization's profitability compare with:

1. Other UK firms in the same sector?

2. Other foreign firms in the same sector?

3. The previous year? 


\section{APPENDIX C}

\section{PRINCALS ENVIRONMENT VARIABLES}

PRINCALS stands for "PRINcipal Component Analysis by means of alternating Least Squares". It is a non-linear technique for detecting relationships within a group of numeric or categorical variables (van den Berg, 1988). The list of variables used in the analysis, their number of categories and the marginal frequencies are presented below in Tables $C .1$ and $C .2$ respectively.

\begin{tabular}{|c|c|c|c|}
\hline \multicolumn{4}{|c|}{ List of variables } \\
\hline Marrables & Wariable label & Number of categories & Measurement level \\
\hline Name 1 & Brand name & 3 & Singie nominal \\
\hline $\operatorname{Loc} 1$ & Fivorable location & 3 & Single nominal \\
\hline Subs 1 & Government subsidies & 3 & Single naminal \\
\hline Patent1 & Exclusive technologies & 3 & Single: nominaal \\
\hline Cust1 & Customer information & 3 & Single rominal \\
\hline Sweost1 & Swwittching costs & 3 & Single nominal \\
\hline Entry 1 & Distribution channels & 3 & Single nominal \\
\hline Raw1 & Access to raw materials & 3 & Shinglle rominal" \\
\hline Adver 1 & Advertising is fierce & 3 & Single nomima: \\
\hline
\end{tabular}

Table C.1: List of variables used in PRINCALS analysis

The variables in this analysis were treated as nominal instead of ordinal, because the category quantifications after initial analysis appeared to be equal on many variables. This indicates that the imposed order of the categories does not allow for an optimal solution. Treating the variables as nominal allows PRINCALS the freedom to adopt an ordering that leads to an optimal solution. The examination of the category quantifications also leads to the deletion of seven variables from the initial variable list. On these variables the distinction between the supposedly opposite categories of 'correct' and 'incorrect' was insufficient. The seven deleted variables are the following:

1. The products that the company buys from its most important supplier also determine the quality of the company's final product

2. An increase in the scale of production will lead to a considerable decrease in the average costs per unit produced

3. Competition intensifies due to an increase in the number and/or power of substitute products

4. The industry's product influence to a large extent the quality of the products of clients

5. It is hard for other companies to enter the industry because of the existence of considerable resources sunk in the companies already present in the industry

6. There is only slow growth in the industry, implying that only limited entry accommodation can occur without this having an impact on the sales of established companies

7. The companies in the industry have recently increased their productive capacity 
substantially.

Finally, on the basis of examining the category quantifications, the categories 'slightly correct" and 'slightly incorrect' were combined into a category 'undecided".

\begin{tabular}{|c|c|c|c|c|}
\hline \multicolumn{5}{|c|}{ Marginal frequencles } \\
\hline \multirow[t]{2}{*}{ Variable } & \multirow[t]{2}{*}{ Missing } & \multicolumn{3}{|l|}{ Categorias } \\
\hline & & 1 & 2 & 3 \\
\hline Name 1 & 0 & 6 & 17 & 15 \\
\hline Loc 1 & 0 & 11 & 20 & 7 \\
\hline Subs 1 & 0 & 13 & 8 & 17 \\
\hline Patervt 1 & 0 & 9 & 18 & 11 \\
\hline Cust1 & 0 & 8 & 18 & 112 \\
\hline Swcosti & 0 & 16 & 19 & 3 \\
\hline Entry1 & 0 & 16 & 18 & 4 \\
\hline Raw 1 & 0 & 17 & 14 & 7 \\
\hline Adver 1 & 0 & 19 & 11 & 8 \\
\hline
\end{tabular}

Table C.2: Categories and marginal frequencies used in PRINCALS

The analysis performed with the list of final variables, results in a solution with two optimal dimensions that together explain $69 \%$ of the variance. The associated eigenvalues are presented in Table C. 3.

\begin{tabular}{|l|l|}
\hline Dimension & Eigenwalue \\
\hline 1 & .4479 \\
\hline 2 & .2428 \\
\hline
\end{tabular}

Table C. 3: Eigenvalues of environmental dimensions

A third dimension was not included because its eigenvalue of 0.1055 does not meet the criterion of $1 /$ number of variables $(9)=0.1111$. To determine which variables load on which dimensions, the highest component loading for each dimension is divided by two. This results in a cut-off point of 0.4305 for dimension 1 and a cut-off point of 0.4295 for dimension 2 . Although "switching cost" on dimension 1 does meet this criterion, it was nat included in the analysis because of the large discrepancy with the other loadings. The component loadings for the different variables are summarized in Table C. 4 . 


\begin{tabular}{|c|c|c|c|c|}
\hline \multicolumn{5}{|c|}{ Component loadings } \\
\hline \multicolumn{2}{|l|}{ Variable } & \multicolumn{2}{|l|}{ Dimension 1} & Dimension 2 \\
\hline \multicolumn{2}{|l|}{ Mame } & \multicolumn{2}{|l|}{$.692 *$} & .347 \\
\hline \multicolumn{2}{|l|}{ Loc1 } & \multicolumn{2}{|l|}{.792} & .132 \\
\hline \multicolumn{2}{|l|}{ Subs 1} & \multicolumn{2}{|l|}{$.738^{*}$} & -.376 \\
\hline \multicolumn{2}{|l|}{ Patent: } & \multicolumn{2}{|l|}{$.846^{*}$} & -.060 \\
\hline \multicolumn{2}{|l|}{ Cust1 } & \multicolumn{2}{|l|}{$-746 *$} & .426 \\
\hline \multicolumn{2}{|l|}{ Swcost } & \multicolumn{2}{|l|}{480} & $612 *$ \\
\hline \multicolumn{2}{|l|}{ Entry 1} & \multicolumn{2}{|l|}{-.358} & $-.764 *$ \\
\hline \multicolumn{2}{|l|}{ Raw 1} & \multicolumn{2}{|l|}{$-.961 *$} & .158 \\
\hline \multicolumn{2}{|l|}{ Adver 1} & \multicolumn{2}{|l|}{.090} & $-859 *$ \\
\hline Iteration number & Tatal fit & Total lass & Multiple lass & Single loss \\
\hline 25 & .6906 & 1.3094 & 1.2304 & .0790 \\
\hline
\end{tabular}

* = Wariablie belongs to dimension 1

* * wariable belongs to dimension 2

Table C.4: Components loadings of envirommental variables 


\section{APPENDIX D}

\section{CLUSTER ANALYSIS}

The objective of cluster analysis is to form groups of abjects in such a way that objects in the same group are similar to each other, whereas objects in different groups are as dissmillar as possible. Two clustering algorithms were used. One partitioning method, Partitioning around Medoids (Kaufman \& Rousseeuw, 1990) and one hierarchical method, SPSS Single Linkage (SPSS-X User's Guide, 1988).

Although the partitioning method was applied to 2 to 5 clusters, for reasons of brevity only characteristics of the chosen cluster solution are presented here. For the hierarchical method the complete analysis is reported.

\section{Food \& drinks}

\section{Partitioning around medoids for $k=3$}

The three resulting clusters have the following characteristics:

* Cluister 1 is isolated, with diameter 1.05 and separation 1.21

* Cluster 2 is not isolated, with diameter 0.87 and separation 0.84

* Cluster 3 is isolated, with diameter 1.14 and separation 0.84

The silhouette width of the clusters is then determined to examine the composition and strength of the three clusters. The results are presented in Table D. 1 . The analysis reveals that Cluster I has an average silhouette width of 0.75 , Cluster II has an average silhouette width of 0.57 and Cluster III has and average silhouette width of 0.46 . For the entire data set, the average silhouette width is 0.63 .

00000000000000000000000001

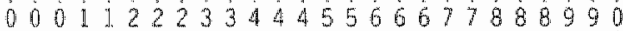

04826048260482504826048260

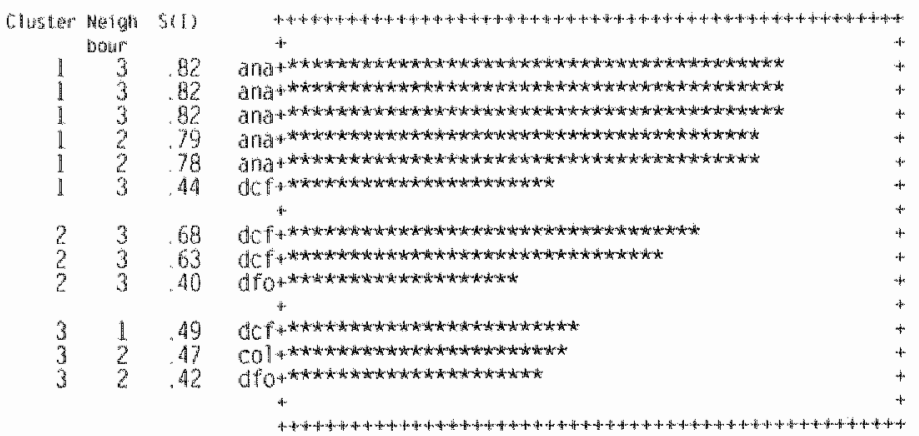

ana $=$ analyzer ${ }$ dcf $=$ combination of differentiation, cost leadership and focus, dfo $=$ differen . tiation focus, $c o l=$ cost leadership

Table D.1: Silhouette of three food \& drink clusters using PAMS 
The proposed decision criteria according to Kaufman and Rousseeuw (1990) are summarized in Table D.2.

\begin{tabular}{|l|l|}
\hline Silhouette Coefficient & Proposed interpretation \\
\hline $0.71-1.00$ & A strong structure has been found \\
\hline $0.51-0.70$ & A reasonable structure has been found \\
\hline $0.26-0.50$ & $\begin{array}{l}\text { The structure is weak and could be artificial, } \\
\text { please try additional methods on this datiaset }\end{array}$ \\
\hline$<0.26$ & No substantial structure has been found \\
\hline
\end{tabular}

Table D.2: Interpretation of silhouette coefficients according to Kaufman and Rousseeuw (1990)

Taking the criteria of Table D. 2 into account the cluster structure in the food \& drink industry can be considered reasonable. Nonetheless also a hierarchical clustering method is performed to check whether the same results appear. This procedure is summarized below.

\section{Singlle linkage}

The agglomeration schedule using single linkage is summarized in Table D.3.

\begin{tabular}{|c|c|c|c|c|c|}
\hline Stage & Chuster $t$ & Cluster 2 & Squared Euclidean distance & $\begin{array}{l}\text { Ist appearance in } \\
\text { cluster }\end{array}$ & $\begin{array}{l}\text { Ist appearance in } \\
\text { chuster } 2\end{array}$ \\
\hline 1 & 2 & 3 & 0.008865 & 0 & 0 \\
\hline 2 & 1 & 4 & 0.009814 & 0 & 0 \\
\hline 3 & 1 & 5 & 0.051307 & 2 & 0 \\
\hline 4 & 1 & 2 & 0.121834 & 3 & 1 \\
\hline 5 & 6 & 11 & 0.287085 & 0 & 0 \\
\hline 6 & 6 & 8 & 0.369407 & 5 & 0 \\
\hline 7 & 7 & 10 & 0.429542 & 0 & 0 \\
\hline 8 & 1 & $\pi 2$ & 0.484588 cut-off & 4 & 0 \\
\hline 9 & 7 & 9 & 0.675804 & 7 & 0 \\
\hline 10 & 6 & 7 & 0.721426 & 6 & 9 \\
\hline 91 & 1 & 6 & 1.476125 & 8 & 10 \\
\hline
\end{tabular}

Table D.3: Agglomeration schedule food \& drink chusters

The associated dendogram using single linkage in which can be seen how the clusters are formed is presented in Table D.4. 
Rescoled Distance cluster Combine

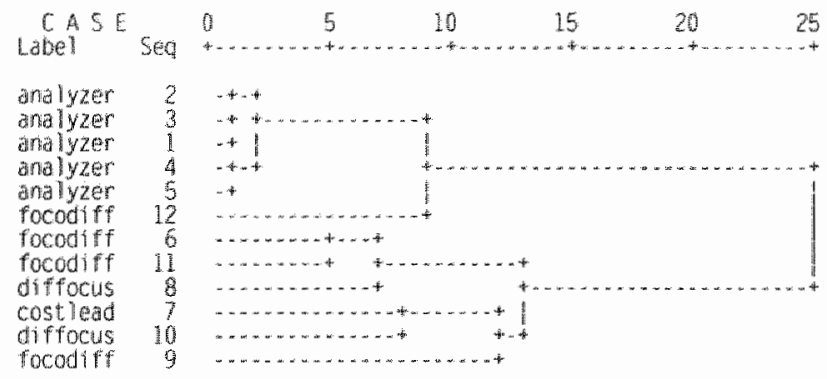

Table D. 4: Dendogram food \& drink clusters

The resulting cluster membership of cases is summarized in Table D.5.

\begin{tabular}{|c|c|c|c|c|}
\hline Labed & Case & 4 clusters & 3 chusters & 2 clusters \\
\hline analyzer & 1 & i & 1 & 1 \\
\hline analyzer & 2 & 1 & 1 & q \\
\hline analyzer & 3 & 9 & 1 & 1 \\
\hline analyzer & 4 & 1 & 1 & 1 \\
\hline analyzar & 5 & 1 & 1 & 1 \\
\hline differentiation ${ }_{\text { cost leadership and focus }}$ & 6 & 2 & 2 & 2 \\
\hline cost leadership & 7 & 3 & 3 & 2 \\
\hline differentiation focus & 8 & 2 & 2 & 2 \\
\hline differentiation, cost leadership and focus & 9 & 4 & 3 & 2 \\
\hline differentiation focus & 10 & 3 & 3 & 2 \\
\hline differentiation, cost leadearship and foces & 11 & 2 & 2 & 2 \\
\hline differentiation, cost leadership and tocus & 12 & 1 & 1 & 1 \\
\hline
\end{tabular}

Table D.5: Cluster membership food \& drink companies

From the agglomeration schedule - which shows the stages of clustering and the proximity values at which items combine to form new clusters -, the dendogram - which graphically displays the stages of clustering - and the cluster membership, it can be concluded that three is the optimal number of clusters in the food \& drink industry. 


\section{Chermicals}

\section{l. Partitioning around Medoids for $k=4$}

The four clusters distinguished in the chemical industry have the following characteristics: Cluster 1 is isolated with diameter 0.69 and separation 0.94 Cluster 2 is isolated, it is a singleton with separation 1.79 Cluster 3 is not isolated with diameter 1.25 and separation 0.94 Cluster 4 is isolated with diameter 0.71 and separation 1.18

The silhouette width of the clusters is then examined to determine the composition and the strength of the clusters. The silhouette coefficients are presented in Table D. 6.
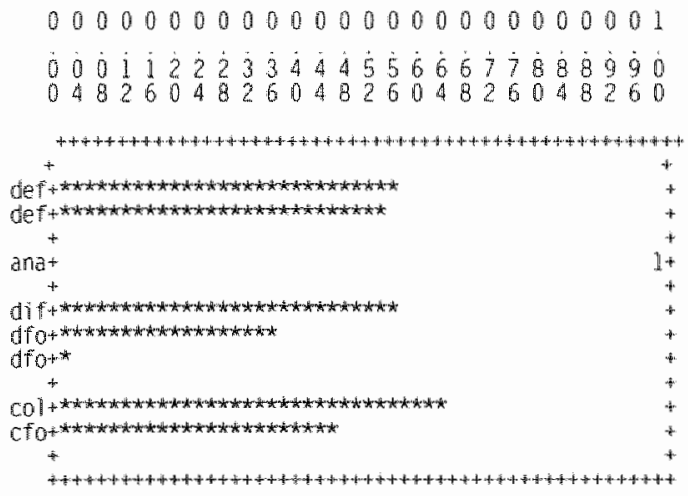

def $=$ defender, ana = analyzer, dif = differentiation, dfo = differentiation focus, $\mathrm{col}=$ cost leadership, cfo $=$ cost focus

Table D.6: Silhouette of four chemical clusters

The analysis reveals that cluster I has an average silhouette width of 0.55 , cluster 11 has an average silhouette width of 0.00 , cluster III has an average silhouette width of 0.32 and cluster IV has an average silhouette width of 0.56 .

For the entire data set in chemicals, the average silhouette width is then 0.40 . When the proposed decision criteria according to Kaufman and Rousseeuw (1990) are examined (Table: D.2) it has to be concluded that the cluster structure is weak and could be artificial. Therefore additional analysis, by means of a hierarchical methods, is necessary. The results of the hierarchical method are presented in the following.

II Single linkage

The agglomeration schedule using single linkage for the chemical industry is presented in Table D.7. 


\begin{tabular}{|l|l|l|l|l|l||}
\hline Stage & Cluster 1 & Cluster 2 & Squared Euclidean distance & $\begin{array}{l}\text { ist appearance } \\
\text { chister } 1\end{array}$ & $\begin{array}{l}\text { 2nd appearance } \\
\text { chuster 2 }\end{array}$ \\
\hline 1 & 4 & 8 & 0.360625 & 0 & 0 \\
\hline 2 & 4 & 6 & 0.464462 & 1 & 0 \\
\hline 3 & 1 & 2 & 0.472802 & 0 & 0 \\
\hline 4 & 5 & 7 & 0.506497 cut off & 0 & 0 \\
\hline 5 & 1 & 4 & 0.877026 & 3 & 2 \\
\hline 6 & 1 & 5 & 1.400777 & 5 & 4 \\
\hline 7 & 1 & 3 & 3.206482 & 6 & 0 \\
\hline
\end{tabular}

Table D.7: Agglomeration schedule for chemical chusters

The associated dendogram using single linkage is presented in Table D.8.

Rescaled Distance Ciuster Combine

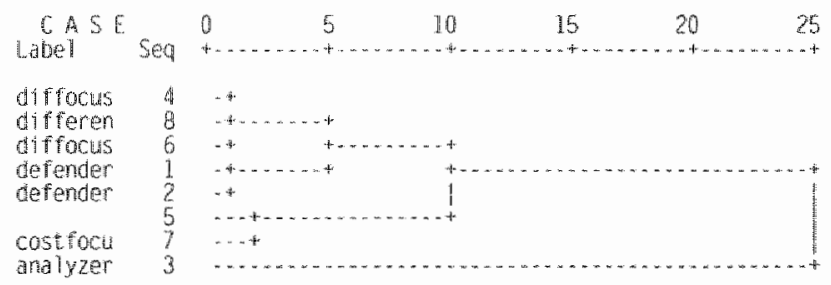

Table D.8: Dendogram for the chemical clusters

Finally the cluster membership using single linkage for the chemical industry is presented in Table D.9.

\begin{tabular}{|c|c|c|c|c|}
\hline Labol & Case & 4 chusters & 3 chusters & 2 chusturs \\
\hline defender & 1 & 1 & 1 & 1 \\
\hline defender & 2 & 1 & 1 & 1 \\
\hline analyzer & 3 & 2 & 2 & 2 \\
\hline differantiatlon focus & 4. & 3 & 1 & 1 \\
\hline cost leadership & 5 & 4 & 3 & 1 \\
\hline differentiation focus & 6 & 3 & $\pi$ & 1 \\
\hline cost focus. & 7 & 4 & 3 & 1 \\
\hline differentiation & 8 & 3 & 1 & 1 \\
\hline
\end{tabular}

Table D.9: Cluster membership of chemical companies

From the agglomeration schedule - which shows the stages of clustering and the proximity values at which items combine to form new clusters : the dendogram - which graphically displays the stages of clustering - and the cluster membership, it can be concluded that four is the optimal number of clusters in the chemicall industry. 


\section{APPENDIX E}

\section{MEAN SCORES ON DEVELOPMENTS IN THE PRODUCTION ENVIRONMENT}

\begin{tabular}{|c|c|c|c|c|c|c|c|c|c|c|c|c|c|c|}
\hline & \multicolumn{2}{|c|}{$\begin{array}{l}\text { Incpease in } \\
\text { number of } \\
\text { different } \\
\text { products }\end{array}$} & \multicolumn{2}{|c|}{ 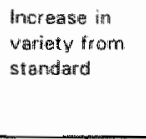 } & \multicolumn{2}{|c|}{ 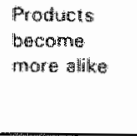 } & \multicolumn{2}{|c|}{$\begin{array}{l}\text { lnorease in } \\
\text { development } \\
\text { lenad whe }\end{array}$} & \multicolumn{2}{|c|}{$\begin{array}{l}\text { Dearatase ha } \\
\text { intermoth }\end{array}$} & \multicolumn{2}{|c|}{$\begin{array}{l}\text { fincorasse in } \\
\text { batch size }\end{array}$} & \multicolumn{2}{|c|}{ 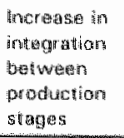 } \\
\hline & LEM & $\mathrm{CP}$ & LBM & $\mathrm{CP}$ & LBMA & $C P$ & LBBM & $\mathbb{C P}$ & LBMA & $C P$ & $\angle B M$ & $C P$ & LBN & $\mathrm{CP}$ \\
\hline $\begin{array}{l}\text { CAD } \\
\text { used }\end{array}$ & 2.8 & 2.0 & 2.7 & 2.3 & 2.5 & 1.5 & 2.5 & 1.6 & 3.8 & 1.5 & 1.7 & 2.3 & 4.0 & 2.0 \\
\hline $\begin{array}{l}\text { CAD not } \\
\text { used }\end{array}$ & 2.8 & 2.3 & 2.5 & 1.8 & 3.3 & 1.8 & 1.0 & 1.8 & 2.6 & 2.3 & 10 & 2.0 & 3. & 1.5 \\
\hline $\begin{array}{l}\text { CAE } \\
\text { used }\end{array}$ & 1.5 & 2.3 & 2.5 & 2.7 & 2.5 & 3.7 & 2.0 & 1,7 & 4.0 & 1.7 & 3.0 & 2.7 & 40 & 2.3 \\
\hline $\begin{array}{l}\text { CAE not } \\
\text { Used }\end{array}$ & 3.1 & 2.0 & 2.6 & 11.6 & 2.9 & 16 & 1.9 & 1.6 & 3.2 & 2.0 & 9.4 & 1.8 & 3.6 & 1. A A \\
\hline $\begin{array}{l}\text { CAMt } \\
\text { Usted }\end{array}$ & 3.0 & 20 & 2.8 & 2.0 & 2.5 & 2.3 & 2.5 & 1.5 & 38 & 1.8 & 1.3 & 1.5 & 4.0 & 1.3 \\
\hline $\begin{array}{l}\text { CAMA not } \\
\text { used }\end{array}$ & 2.7 & 2.3 & 2.5 & 2.0 & 3.0 & 1.0 & 1.5 & 1.6 & 3.1 & 2.0 & 2.0 & 2.8 & 3.7 & 2.0 \\
\hline $\begin{array}{l}\text { CAPP } \\
\text { used }\end{array}$ & 2.3 & 1.0 & 2.4 & 2.0 & 2.7 & 1.0 & 1.9 & 1.0 & 3.6 & 1.0 & 2.0 & 4.0 & 4.0 & 3.0 \\
\hline $\begin{array}{l}\text { CAPHP } \\
\text { nol USEd }\end{array}$ & 4.0 & 2.3 & 3.0 & 2.0 & 3.0 & 1.7 & 2.0 & 1.7 & 2.3 & 2.0 & 1.0 & 1.9 & 3.3 & 1.6 \\
\hline $\begin{array}{l}\text { CNC } \\
\text { tsed }\end{array}$ & 3.0 & $N A$ & 2.7 & $N A$ & $3 . \pi$ & $\mathrm{NA}$ & 1.6 & $N A$ & 3.1 & NA & 1.6 & $N A$ & 3.7 & NA \\
\hline $\begin{array}{l}\text { CNC runt } \\
\text { thsed }\end{array}$ & 2.3 & 2.1 & 2.3 & 2.0 & 2.0 & 16 & 2.7 & 1.6 & 4.0 & 1,9 & 2.0 & 2.7 & $\$, 0$ & 1.8 \\
\hline $\begin{array}{l}\text { CPS } \\
\text { usact }\end{array}$ & 2.6 & 2.0 & 2.2 & 1.2 & 12 & 1.9 & 2.2 & 1,7 & 3.9 & 1.9 & 2.4 & 2.0 & 4.0 & 1.3 \\
\hline $\begin{array}{l}\text { CPS not: } \\
\text { used }\end{array}$ & 3.0 & 2.5 & 3.0 & 3.0 & 2.6 & 1.0 & 1.6 & 1.5 & $2 A$ & 2.0 & 1.0 & 2.6 & 3.6 & 3.0 \\
\hline $\begin{array}{l}\text { FMas } \\
\text { WSed }\end{array}$ & 3.0 & NA & 30 & $\mathbb{N A}$ & 2.3 & NA & 2.3 & $\mathrm{NA}$ & 3.7 & $N A$ & 20 & $\mathrm{NA}$ & 40 & $\mathrm{~N} N \mathrm{~A}$ \\
\hline $\begin{array}{l}\text { FMS nat } \\
\text { nsad }\end{array}$ & 2.7 & 2. & 30 & 2.0 & 3.0 & 1.6 & 1.7 & $1: B$ & 3.2 & 1.9 & $1, B$ & 2.1 & 3.7 & 1.8 \\
\hline $\begin{array}{l}\text { MAP } \\
\text { W5ed }\end{array}$ & 25 & 2.8 & 2.3 & 2.18 & 3.0 & 2.3 & 2.0 & 1. $B$ & 3.6 & 2.3 & 1.9 & 1.5 & 4.0 & 2.0 \\
\hline $\begin{array}{l}\text { MARP nol } \\
\text { used }\end{array}$ & 40 & 1.5 & 4.0 & 1.3 & 2.0 & $9: 0$ & 7.5 & 1.5 & 2.5 & 1.5 & 1.0 & 2.8 & 3.0 & 1.5 \\
\hline $\begin{array}{l}\text { Robbot: } \\
\text { Used }\end{array}$ & 2.3 & $\mathrm{~N} / \mathrm{A}$ & 2.0 & WA & 20 & NA & 20 & $M A$ & 3.5 & $\mathrm{~N}: \mathrm{A}$ & 30 & NA & 4.0 & $\mathrm{NA}$ \\
\hline $\begin{array}{l}\text { Rotots } \\
\text { not used }\end{array}$ & 3.0 & 2.1 & 29 & 20 & $\$ 1$ & 1.6 & 1.9 & 1.6 & 3.3 & 1.9 & 1. $\eta_{i}$ & 2.1 & 3.7 & 1.8 \\
\hline
\end{tabular}

LBM: Large batch and mass production

CP: Continuous process production

NA: Not applicable, automation method not in use

Continued on next page. 


\begin{tabular}{|c|c|c|c|c|c|c|c|c|c|c|c|c|}
\hline & \multicolumn{2}{|c|}{$\begin{array}{l}\text { Incrigatse in } \\
\text { peophlo invelvitud } \\
\text { in tiestagn and } \\
\text { development }\end{array}$} & \multicolumn{2}{|c|}{$\begin{array}{l}\text { Increase in } \\
\text { prople } \\
\text { involved in } \\
\text { production } \\
\text { plentinig }\end{array}$} & \multicolumn{2}{|c|}{ 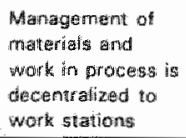 } & \multicolumn{2}{|c|}{$\begin{array}{l}\text { Set up time fico } \\
\text { production } \\
\text { decreases, panti } \\
\text { used more } \\
\text { intensively }\end{array}$} & \multicolumn{2}{|c|}{$\begin{array}{l}\text { meresase in } \\
\text { specialization } \\
\text { of skitls }\end{array}$} & \multicolumn{2}{|c|}{$\begin{array}{l}\text { Increase in } \\
\text { suluc ontr actirger }\end{array}$} \\
\hline & LOM & $\mathrm{CP}$ & LEBA & $C^{\circ}$ & EBM & $C p$ & LBM & $C P$ & LBA & $\mathrm{CP}$ & LBM & $\mathrm{CP}$ \\
\hline $\begin{array}{l}\text { CAD } \\
\text { wased }\end{array}$ & 2.8 & 30 & 31.0 & 3.0 & 2.5 & 1.8 & 4.0 & 40 & 32 & 3.3 & 4.5 & 1.3 \\
\hline $\begin{array}{l}\text { CAD not } \\
\text { UAsed }\end{array}$ & 2.5 & 2.8 & 2.5 & 2.8 & 2.0 & 1.5 & 4.0 & 4.0 & 1.5 & 2.3 & 2.5 & 1.3 \\
\hline $\begin{array}{l}\text { CAEE } \\
\text { Whasd }\end{array}$ & 1.0 & 3.3 & 2.5 & 3.0 & 4.0 & 2.0 & 4.0 & 4.0 & 2.5 & 3.7 & 1.0 & 1.3 \\
\hline $\begin{array}{l}\text { CAE not } \\
\text { usied }\end{array}$ & 3.1 & 2.6 & 2.9 & 28 & 1.9 & 1.4 & 4.0 & 4.0 & 2.5 & 2.2 & 2.1 & 1.2 \\
\hline $\begin{array}{l}\text { CAM } \\
\text { UESED }\end{array}$ & 30 & 3.3 & 2.5 & 3.0 & 2.5 & 1.5 & 4.0 & 4.0 & 3.5 & 3.3 & 1.8 & $\$ .0$ \\
\hline $\begin{array}{l}\text { CHM } \\
\text { not usad }\end{array}$ & 2.5 & 2.5 & 3.0 & 2.8 & 2.2 & 1.8 & 4.0 & 4.0 & 1.8 & 2.3 & 20 & 1.5 \\
\hline $\begin{array}{l}\text { CAPP } \\
\text { Usisd }\end{array}$ & 2.6 & 3.0 & 2.7 & 4.0 & 2.7 & 2.0 & 4.0 & 4.0 & 2.7 & 4.0 & 1.9 & 20 \\
\hline $\begin{array}{l}\text { CAPP } \\
\text { not uged }\end{array}$ & 30 & 2.9 & $3 i, 0$ & 2.7 & 1.3 & 1.5 & 4.0 & 4.0 & 2.0 & 2.6 & 2.0 & 1.1 \\
\hline $\begin{array}{l}\text { CNC } \\
\text { Lised }\end{array}$ & 2.7 & $N A$ & 2.3 & $N A_{6}$ & 2.4 & NA & 40 & NAA & 2.3 & $N A$ & 2.3 & $N A$ \\
\hline $\begin{array}{l}\text { CNC not } \\
\text { used }\end{array}$ & 2.7 & 2.9 & 4.0 & 2.9 & 2.0 & 青.6 & 4.0 & 4.0 & 30 & 2.8 & 1.0 & 1.3 \\
\hline $\begin{array}{l}\text { CPS } \\
\text { usised }\end{array}$ & 2.8 & 28 & 3.4 & 2.5 & 2.2 & 1.7 & 4.0 & 4.0 & 2,4 & 2.8 & 1.0 & 1.2 \\
\hline $\begin{array}{l}\text { Cips not } \\
\text { used }\end{array}$ & 2.6 & 3.0 & 2.2 & 4.0 & 2.4 & 1.5 & 40 & 4.0 & $2.6 \mathrm{i}$ & 2.5 & 2.8 & $7: 5$ \\
\hline $\begin{array}{l}\text { FMS } \\
\text { wsed }\end{array}$ & 3.0 & NA & 3.0 & $\mathrm{NA}$ & 3.0 & $N A$ & 4.0 & $\mathrm{NA}$ & 3.0 & $\mathbb{N A}$ & 2.0 & NA \\
\hline $\begin{array}{l}\text { FMS not } \\
\text { usud }\end{array}$ & 3.0 & 2.9 & 27 & 2.9 & 2,0 & 16 & 4.0 & 40 & 2.3 & 2.8 & 1.9 & 1.3 \\
\hline $\begin{array}{l}\text { MRPP } \\
\text { URBed }\end{array}$ & 2.4 & 3.55 & 2.9 & 3.3 & 2.11 & 1.5 & 4.0 & 4.0 & 2.3 & 3.0 & 1.4 & 1.0 \\
\hline $\begin{array}{l}\text { MHFP not } \\
\text { Hised }\end{array}$ & 40 & 2.3 & 2.5 & 2.5 & 3.0 & 9.8 & 4.0 & 4.0 & 3.5 & 2.5 & 4.0 & 11.5 \\
\hline $\begin{array}{l}\text { Pobouts } \\
\text { wised }\end{array}$ & $3: 0$ & $\mathbb{N A}$ & 3.0 & NA & $3 . \ddot{0}$ & NA. & 4.0 & NA & 20 & $\mathrm{NA}$ & 2.0 & $\mathrm{NA}$ \\
\hline $\begin{array}{l}\text { Fobots } \\
\text { not us.er }\end{array}$ & 2.6 & 2.9 & 2.7 & 2.9 & 2.0 & 16 & 4.0 & 4.0 & 2.7 & 2.8 & 1.9 & 1.3 \\
\hline
\end{tabular}

LEM: Large batch and mass production

CP: Continuous process production

NA: Not applicable, automation method not in use

Table E. 1: Mean scores on developments in the production environment 


\section{REFERENCES}

Adler, P.S. (1988), Managing Flexible Automation, California Management Review, 30 , 34-56.

Adler, P.S. (1989), Technology Strategy: Guide to the Literature, in: Research on Technological Innovation, Management and Policy: A Research Annual, Rosenbloom, R.S. and Burgelman, R.A. (eds), JA. Press, Greenwich, CT, "i-25. Albeda, W., Dercksen, W.J. (1989), Arbeidsverhoudingen in Nederland, 4th edition, Samsom, Alphen a/d Rijn.

Aldrich, H.E., Pfeffer, J. (1976), Organizations and Environments, Annual Review of Sociology, 2, 79-105.

Altman, E.l. (1971), Corporate Bankruptcy in America, Heath Lexington Books, Lexington.

Ames, R.T. (1994), Sun-Tzu: de Kunst van Het Oorlogsvoeren, Areopagus, Vianen. Ansoff, H.1. (1965). Corporate Strategy: An Analvtic Approach to Business Policy for Growth and Expansion, McGraw-Hill, New York.

APPE: Association of Petrochemical Producers in Europe (1993), Activity Review 1992-1993: Adapting to the Global Market, CEFIC, Brussel.

Arthur, J.B. (1994), Effects of Human Resource Systems on Manufacturing Performance and Turnover, Academy of Management Journal, 37, 670-687.

Baird, L., Meshoulam, 1. (1988), Managing Two fits in Strategic Human Resource Management, Academy of Management Review, 13, $1116-128$.

Barnard, C.I. (1938), The Functions of the Executive, Harvard University Press, Cambridge, Mass.

Begin, J.P. 11992), Comparative Human Resource Management (HRM): A Systems Perspective, The International Journal of Human Resource Management, 3,379 408.

Benders, J.G.J.M. (1992), Fabricagetechnologie en Arbeidsorganisatie: een Theoretische Beschouwing, in: Frambach, R.T., Nijssen, E.J. leds). Technologie en Strategisch Management, Lemma, Utrecht.

Berg van den, G. (1988), PRINCALS voor Beginners, Department of Data Theory, University of Leiden, RR-88-11.

Blackburn, R., Rosen, B. (1993). Total Quality and Human Resources Management: Lessons Learned from Baldridge Award-winning Companies, Academy of Management Executive, 7, 49-66.

Blau, P.M. McHugh Falbe, C., McKinley, W. Tracy, P.K. 11976), Technology and Organization in Manufacturing, Administrative Science Quarter/y, 21, 20-40. 
Boone, C., Brabander de, B., Witteloostuijn, van A. (1993), Het Verband tussen de Samenstelling van het Topmanagement Enerzijds en het Adaptievermogen van Organisaties Anderzijds: Een Contingentiebenadering, Onderzoeksmemorandum. 93-049, Faculteit der Economische Wetenschappen, Rijksuniversiteit Limburg. Boone, C., Witteloostuijn, van A. (1995), Industrial Organization and Organizational Ecology: The Potential for Cross-Fertilization, Organization Studies, 16, 265 298.

Bowen, D.E., Ledford, G.E., Nathan, B.R. (1991), Hiring for the Organization, Not the Job, Academy of Management Executive, 5, 35-51.

Brealey, R. Myers, S. 119841, Principles of Corporate Finance, 2nd edition, McGrawHill, Singapore.

Brewster, C. (1993), Developing a 'European' Model of Human Resource Management, The international Journal of Human Resource Management, 4, 765-783.

Brewster, C., Larsen, H.H. (1992), Human Resource Management in Europe: Evidence from Ten Countries, International Journal of Human Resource Management, $\mathbf{3}$, 409-434.

Brown, D.M., Laverick, S. (1994), Measuring Corporate Performance, Long Range Planning, 27, 89.98.

Bryman, A. (1989), Research Methods and Organization Studies, Unwin Hyman, Boston.

Buffa, E.S., Sarin, R.K. (1987), Modern Production/Operations Management, Wiley. New York.

Buitendam, A. (1987). The Horizontal Perspective of Organization Design and New Technology, in: New Technology as Organizational Innovation, Pennings, J.M., Buitendam, A. (eds), Ballinger, Cambridge.

Burns, T., Stalker, G.M. (1961), The Management of Inmovation, Tavistock, London. Butler, J.E., Theories of Technological Innovation as Useful Tools for Corporate Strategy, Strategic Management Journal, 9, 15-29.

Castrogiovanni, G.J. (1991), Environmental Munificence: A Theoretical Assessment, Academy of Management Review, 16, 542-565.

Cavestro, W. (1989). Automation, New Technology and Work Content, in: The Transformation of Work, Wood, S. (ed), Routledge, London.

CBS (1990), Volwasseneneducatie, Bedriffsopleidingen, 1990, Deel 1: Particuliere Sector, Heerlen.

CBS (1993), Statistical Yearbook, The Hague.

CBS (1994), Statistical Yearbook of the Netherlands, Heerlen.

CEFIC (1993): European Chemical Industry Council, Economic outlook of the European Chemical Industry and Basic Economic Statistics 1991-1992, Brussels.

CEFIC (1993a): European Chemical Industry Council, Facts and Figures: The European Chemical Industry in a Worldwide Perspective. Brussels. 
Chakravarthy, B.S. (1986), Measuring Strategic Performance, Strategic Management Journal, 7. 437-458.

Chandler, A.D., Jr 11962), Strategy and Structure: Chapters in the History of the American Industrial Enterprise, M.I.T. Press, Cambridge, MA.

Child, J. (1972), Organizational Structure, Environment and Performance: The Role of Strategic Choice, Sociology, 6, 1-22.

Child, J. (1987), Managerial Strategies, New Technology, and the Labor Process, in: New Technology as Organizational Innovation, Pennings, J.M., Buitendam, A. (eds), Ballinger, Cambridge.

Child, J., Ganter, H.D., Kieser, A. (1987), Technology Policy and Innovation in Organizations, in: New Technology as Organizational Mnovation, Pennings. J.M. and Buitendam, A. (eds), Ballinger, Cambridge.

Chrisman, J.J., Hofer, C.W., Boulton, W.R. (1988), Toward a System for Classifying Business Strategies, Academy of Management Review, 13, 413-428.

Clark, T., Mallory, G., Pugh, D. (1993), International Organizational Observatory: British Feedback Report No.1. School of Management, The Open University, Great Britain.

Commission of the European Communities (1993), Panorama of EC industry-1993, Office for Official Publications of the European Communities, Luxemburg.

Conant, J.S., Mokwa, M.P., Rajan Varadajaran, P.R. (1990), Strategic Types, Distinctive Marketing Competencies and Organizational Performance: A Multiple Measure-Based Study, Strategic Management Journal, 11, 365-383.

Cool, K., Dierickx, I. (1993), Rivalry, Strategic Groups and Firm Performance, Strategic Management Journal, 14, 47-59.

Cool, K.O., Schendel, D. (1987), Strategic Group Formation and Performance: The Case of the US Pharmaceutical Industry 1963-1982, Management Science, 33, $1102-1124$.

Coopers \& Lybrand, Berenschot 11994), Ken- en Stuurgetallen voor Personeelsmanagement, Resultaten Nederland 1994, Coopers \& Lybrand and Berenschot, Utrecht.

Cronshaw, M., Davis, E., Kay, J. 11994), On Being Stuick in the Middle or Good Food Costs Less at Sainsbury's, British Journal of Management, 5, 19-32.

Crouch, C. (1990). United Kingdom: The Rejection of Compromise, in: European Industrial Relations: The Challenge of Flexibility, Baglioni, G. and Crouch, $\mathrm{C}$. (eds), Sage, London.

Crouch, C. (1994), Beyond Corporatism: The Impact of Company Strategy, in: New Frontiers in European Industrial Relations, Hyman, R. and Ferner, A. (eds), Blackwell, Oxford.

CSO 11994). Annual Abstract of Statistics 1994, Government Statistical Service. London. 
Daft, R.L. (1992), Organization Theory and Design, 4th edition, West, St. Paul, MN.

Dean, J.W., Snell, S.A. 119911, Integrated Manufacturing and Job Design: Moderating Effects of Organizational Inertia, Academy of Management Journal, 34, 776 804.

Dean, J.W., Yoon, S.J., Susman, G.l. (1992), Advanced Manufacturing Technology and Organization Structure: Empowerment or Subordination, Organization Science, 3, 203-229.

Dess, G.G., Davis, P.S. (1984), Porter's (1980) Generic Strategies as Determinants of Strategic Group Membership and Organizational Performance, Academy of Management Journal, 27, 467-488.

Dess, G.S., Robinson, R.B. (1984), Measuring Organizational Performance in the Absence of Objective Measures, Strategic Management Journal, 5, 265-273.

Dijk, wan N., Punch, M. (1993), Open Borders, Closed Circles: Management and Organization in the Netherlands, in: Management in Western Europe: Society, Culture and Organization in Twe/ve Nations, Hickson, D.J. (ed). De Gruyter, Berlin.

Dill, W.R. (1958), Environment as an Influence an Managerial Autonomy, Adrinistrative Science Quarterly, 2, 404-443.

Dimaggio, P.J., Powell, W.W. 11983), The Iron Cage Revisited: Institutional Isomorphism and Collective Rationality in Organizational Fields, American Sociological Review, 48, 147-160.

Drazin, R., Van de Ven, A.H. (1985), Alternative Forms of Fit in Contingency Theory, Administrative Science Quarterly, 30, 514-539.

Duimering, P.R., Safayeni, F., Purdy, L. (1993), Integrated Manufacturing: Redesign the Organization before Implementing Flexible Technology, Sloan Management Review, Summer, 47-56.

Dussauge, P., Hart, S., Ramanantsoa, B. (1992), Strategic Technology Management, Wiley, New York.

Dvir, D., Segev, E., Shenhar, A. (1993), Technology's Varying Impact on the Success of Strategic Business Units within the Miles and Snow Typology, Strategic Management Journal, 14, 155-162.

Edwards, P., Hall, M., Hyman, R., Marginson, P., Sisson, K., Waddington, J., Winchester, D. (1992), Great Britain: Still Muddling Through, in: Industrial Relations in the New Europe, Ferner, A. and Hyman, R. (eds), Basill Blackwell, Oxford.

Ettlie, J.E. (1986), Implementing Manufacturing Technologies: Lessons from Experience, in: Managing Technological Innovation, in: Davis, D.D. and Associates (eds), Jossey-Bass, San Francisco.

Evan, W.M. (1966), The Organization Set, in: Approaches to Organizational Design, Thompson, J.D. (ed), University of Pittsburgh Press, Pittsburgh.

Fayol, H.F. (1916), Administration Industrielle et Générale, Dunod, Paris. 
Financieele Dagblad 119911. De Omzet Cijfers van 1990, 19 November 1991. Amsterdam.

Fisscher, O.A.M., Middel, H. Vinke, R.H.W. 11992), Inleiding HRM: een Ontwikkeling mar ook een Visie, in: HRM: De Praktijk Gewogen. Fisscher, O.A.M. Middel, H., Vinke, R.H.W. (eds), Kluwer Bedrijfswetenschappen, Deventer.

Fox, S., Mcleay, S. (1992), An Approach to Researching Manageriall Labour Markets: HRM, Corporate Strategy and Financial Performance in UK Manufacturing, The International Journal of Human Resource Management, 3, 523-554.

Fry. L.W. (1982), Technology-Structure Research: Three Critical Issues, Academy of Management Journal, 25, 532-552.

Galbraith, J. (1973), Designing Complex Organizations, Addison Wesley, Reading, Mass.

Gaspersz, J.B.R. (1993), De Keuze voor de Interne Arbeirlsmarkt: een Verkennende Studie vanuit de Optiek van het Personee/smanagement. Elinkwijk BV, Utrecht. Gerwin, D. (1981), Relationship between Structure and Technology, in: Handbook of Organizational Design. Volume 2: Remodeling Organizations and their Enviromments, Nystrom, P.C. and Starbuck, W.H. ledsl, Oxford University Press, New York.

Gillespie, D.F., Mileti, D.S. (1977). Technology and the Study of Organizations: An Overview and Appraisal, Academy of Management Review, January, 7-16.

Gomez-Meija, L. (1992), Structure and Process of Diversification, Compensation Strategy, and Firm Performance, Strategic Management Journal, 13, 381-397. Govindarajan, V. (1988). A Contingency Approach to Strategy implementation at the Business-Unit Level: Integrating Administrative Mechanisms with Strategy, Academy of Management Journal, 31, 828-853.

Govindarajan, V., Fisher, J. (1990), Strategy, Control Systems and Resource Sharing: Effects on Business-Unit Performance, Academy of Management Journal, 33, 259-285.

Guest, D.E. 11987), Human Resource Management and Industrial Relations, Journal of Management Studies, 24, 503-521.

Guest, D.E. (1990), Human Resource Management and the American Dream, Journal of Management Studies, 27, 377-397.

Guest, D.E. (1992), Human Resource Management in the United Kingdom, in: The Handbook of Human Resource Management, Towers, B. (ed), Blackwell, Oxford.

Habib, M.M., Victor, B. (1991), Strategy, Structure and Performance of US Manufacturing and Service MNC's: A Comparative Analysis, Strategic Management Journal, 12, 589-606.

Hambrick, D. (1983a), An Empirical Typology of Mature Industrial-Product Environments, Academy of Management Journal, 26, 213-230.

Hambrick, D. (1983b). High Profit Strategies in Mature Capital Goods Industries: A Contingency Approach, Academy of Management Journal, 26, 687-707. 
Hannan, M.T., Freeman, J. 11989), Organizational Ecology, Harvard University Press, Cambridge, Mass.

Hatten, K.J., Hatten, M.L. (1988), Effective Strategic Management: Analysis and Action, Prentice Hall, Englewood Cliffs, NJ.

Have ten, K. (1993), Markt, Organisatie en Personeel in de Industrie, Tilburg Uniwersity Press, Tilburg.

Hayes, R.H., Wheelwright, S.C. 119841, Restoring our Competitive Edge: Competing through Manufacturing, Wiley, New York.

Hayes, R.H., Wheellwright, S.C., Clark, K.B. (1988), Dynamic Manufacturing: Creating the Learning Organization. The Free Press, New York.

Heijtjes, M.G., Sorge, A., Witteloostuijn, van A. (1993), International Organizational Observatory: Descriptive Report The Netherlands, Faculty of Economics and Business Administration, University of Limburg, Maastricht.

Heililjes, M.G., Sorge, A., Witteloostuijn, van A. (1995, forthcoming). An Internationall Comparison: Strategies Pursued in Competitive Environments, in: International Feedback Report 100, Pugh, D.S., Clark, T. (eds).

Heino, V.(1993). Strategies and Performance Chemical Industry 1982-1991, Helsinki School of Economics and Business Administration, ARTTO-project 1992-1993. Henderson, R.M., Clark, K.B. 11990), Architectural Innovation: The Reconfiguration of Existing Product Technologies and the Failure of Established Firms, Administrative Science Quarterly, 35, 9-30.

Herbert, T.T., Deresky, H. (1987), Generic Strategies: An Empirical Investigation of Typology Validity and Strategy Content, Strategic Management Journal 8,135 147.

Hetebrij, M., Jonker, B.F.L. (1992), Implicaties van Technologische Ontwikkelingen voor de Human Resources, in: Frambach, R.T., Nijssen, E.J. (eds). Technologie en Strategisch Management, Lemma, Utrecht..

Hickson, D.J., Pugh, D. S., Pheysey, D.C. (1969), Operations Technology and Organization Structure: An Empirical Appraisal, Administrative Science Quarterly, 14, 378-397.

Hill, C.W.L. (1988), Differentiation Versus Low Cost or Differentiation and Low Cost: A Contingency Framework, Academy of Management Review, 13, 401-412. Hofstede, G. (1991), Cultures and Organizations: Software of the Mind, Mc Graw-Hill. London.

Hrebiniak, L.G., Joyce, W.F. (1985), Organizational Adaptation: Strategic Choice and Environmentall Determinism, Administrative Science Quarterly, 30, 336-349.

Hunter, L., McGregor, A., Maclnnes, J., Sproull, A. (1993), The 'Flexible Firm': Strategy and Segmentation, British Journal of Industrial Relations, 31, 383-405. Hutt, M.D., Speh, T.W. 11986), Industrial Marketing Management: a Strategic View of Business Markets, 2nd edition, Dryden, Chicago. 
Itami, H., Numagami, T. (1992), Dynamic Interaction between Strategr and Technolagy, Strategic Management Journal, 13, 119-135.

Iterson, van A., Olie, R. (1992), European Business Systems: the Dutch Case, in: European Business Systems: Firms and Markets in their National Contexts. Whitley, R. (ed), Sage Publications, London.

Janssen, A.M.C. (1992), Knelpunten op de Arbeidsmarkt, Gids voor

Personeelsmanagement, 1, 8-11.

Jellinek, M., Goldhar, لا.D. 11984). The Strategic Implications of the Factory of the Future, Sloan Management Review, Summer, 29-37.

Johnson, G., Scholes, K. (1993), Exploring Corporate Strategy: Text and Cases, Prentice Hall. New York.

Kaplan, R.S., Norton, D.P. (1992), The Balanced Scorecard - Measures That Drive Performance, Harvard Business Review, Jan-Feb, 71.79.

Kaplan, R. S. Norton, D.P. (1993), Putting the Balanced Scorecard to Work, Marvard Business Review, Sept-Oct, 134-147.

Kaufman, L., Rousseeuw, P.J. (1990), Finding Groups in Data: An Introduction to Cluster Analysis, Wiley \& Sons, New York..

Kelley, M.R. (1989), Alternative Forms of Work Organization under Programmable

Automation, in: The Transformation of Work, Wood, S. (ed), Routledge. London.

Kerckhoffs, C., Neubourg de, C., Palm, F. 11994), The Determinants of Unemployment and Job Search Duration in the Netherlands, De Economist, 142, 21-42.

King, P. (1990), The Business Culture in the Netherlands, in: Business Cultures in Europe, Randlesome, C. (ed), Butterworth-Heinemann, Oxford.

Klink, van der M., Mulder, M. (1995), Human Resource Development and Staff Flow Policy in Europe, in: International Human Resource Management, Harzing, A-W., Ruysseveldt, van J. (eds), Sage, London.

Khuytmans, F. (1989). Tussen Verzakelijking and Vernieuwing: De Belofte van Human Resource Management, in: Human Resource Management: Verzakelijking of Vernieuwing ?, Kluijtmans, F. (ed), Kluwer Bedriffswetenchappen/Open Universiteit, Heerlen.

Kluytmans, F. (1990), Ontwikkelingen in het Personeelsmanagement: Ean Historische Schets, in: Leerboek Personeelsmanagement, Kluytmans, F. , Hancké, C. (eds), Kluwer Bedrijfswetenschappen/Open Universiteit, Deventer/Heerlen.

Katha, S., Orne, D. (1989), Generic Manufacturing Strategies: A Conceptual Synthesis, Strategic Management Journal, 10, 211-231.

Kotler, P. (1991), Marketing Management: Analysis, Planning, Implementation and Control, 7 th edition, Prentice Hall, Englewood Cliffs.

Lane, C. 11992), European Business Systems: Britain and Germany Compared, in: European Business Systems: Firms and Markets in their National Contexts. Whitley, R. (ed), Sage Publications, London. 
Lane, C. (1994), Industral Order and the Transformation of Industrial Relations: Britain, Germany and France Compared, in: New Frontiers in European Industrial Relations, Hyman, R., Ferner. A. (eds), Blackwell, Oxford.

Lawrence, P.R., Lorsch, J.W. (1967), Differentiation and Integration in Complex Organizations, Administrative Science Quarterly, 12, 1-4.7.

Lengnick-Hall, C.A., Lengnick-Hall, M.L. (1988), Strategic Human Resources Management: A Review of the Literature and a Proposed Typology, Academy of Management Review, 113, 454 470.

Mascarenhas, B. Aaker, D.A. (1989), Mobility Barriers and Strategic Groups, Strategic Management Journal, 10, 475-485.

Maurice, M., Sorge, A., Warner, M. (1980), Societal Differences in Organizing Manufacturing Units: A Comparison of France, West Germany, and Great Britain, Organization Studies, 1, 59-86.

Mayo, E. (1945). The Social Problems of an Industrial Civilization, Harvard University Graduate School of Business Administration, Boston.

McGuire, J., Schneeweis, T., Hill, J. 11986), An Analysis of Alternative Measures of Strategic Performance, Advances in Strategic Management, 4, 127-154.

Mckee, D.O., Rajan Varadarajan, P., Pride, W.M. 11989), Strategic Adaptability and Firm Performance: A Market Contingent Perspective, Journal of Marketing, 53 $21-35$.

McKinlay, A., Starkey, K. (1992), Strategy and Human Resource Management. International Journal of Human Resource Management, 3, 435-450.

Meredith, J. (1987). The Strategic Advantages of New Manufacturing Technologies for Small Firms, Strategic Management Journal, 8, 249-258.

Meredith, J., McTavish, R. (1992), Organized Manufacturing for Superior Performance, Lang Range Planning. 25, 63-71.

Miles, R.E., Snow, C.C. (1978), Organizational Strategy, Structure and Process, McGraw-Hill, New York.

Miles, R.E., Snow, C.C. (1984), Designing Strategic Human Resource Systems, Organizational Dynamics, Summer, 36.52.

Miller, A. (1988), A Taxonomy of Technological Settings, with Related Strategies and Performance Levels, Strategic Management Journal, 9, $239-254$.

Miller, A., Dess, G.G. (1993), Assessing Porter's (1980) Model in Terms of its Generalizability, Accuracy and Simplicity, Journal of Management Studies, 30. $553-585$.

Miller, D. (1986), Configurations of Strategy and Structure: Towards a Synthesis, Strategic Management Journal, 7, 233-249.

Miller, D. (1987a), Strategy making and Structure: Analysis and Implications for Performance, Academy of Management Journal, 30, 7-32.

Miller, D. (1987b), The Structural and Environmental Correlates of Business Strategy, Strategic Management Journal, 8, 55-76. 
Miller, D. (1988), Relating Porter"s Business Strategies to Environment and Structure: Analysis and Performance Implications, Academy of Management Jounal, 31. 280-308.

Miller, D., Friesen, P.H. 119841, A Longitudinal Study of the Corporate life Cycle. Management Science, 10, 1161-1183.

Miller, D., Friesen, P.H. (1986a), Porter's (1980) Generic Strategies and Performance: An Empirical Examination with American Data. Part 1: Testing Porter, Organization Studies, 7, 37-55.

Miller, D., Friesen, P.H. (1986b), Porter's (1980) Generic Strategies and Performance: An Empirical Examination with American Data. Part 2: Performance Implications, Organization Studies, 7, 255-261.

Miller, J.G., Roth, A.V. (1994), A Taxonomy of Manufacturing Strategies, Management Science, 40, 285-304.

Milliman, J., Von Glinow, M.A. Nathan, M. (1991), Organizational Life Cycles and Strategic International Human Resource Management: Implications for Congruence Theory, Academy of Management Review, 16, 318-339.

Mintzberg, H. (1983). Structure in Fives: Designing Effective Organizations, Prentice Hall, Englewood Cliffs.

Mintzberg, H. (1988), Opening up the definition of strategy, in: The Strategy Process:" Concepts, Contexts, and Cases, Quinn, J.B., Mintzberg, H., James, R.M. (eds). Prentice Hall International, London.

Morrison, A.J., Roth, K. (1992), A Taxonomy of Business-Level Strategies in Global Industries, Strategic Management Journal, 13, 399-418.

Murray, A.1.(1988), A Contingency View of Porter"s "Generic Strategies", Academy of Management Review, 13, 390-400.

Naman, J.L., Slevin, D.P. (1993), Entrepreneurship and the Concept of Fit: A Model and Empirical Tests, Strategic Management Journal, 14, 137-153.

Nemetz, P.L., Fry, L.W. (1988). Flexible Manufacturing Organizations: Implications for Strategy Formulation and Organization Design. Academy of Management Review, 17, 86-111.

Parker, B., Helms, M.M. (1992), Generic Strategies and Firm Performance in a Declining Industry, Management International Review, 32, 23-39.

Parthasarthy, R., Sethi, S.P. (1992). The Impact of Flexible Automation on Business Strategy and Organizational Structure, Academy of Management Review, 17, 86-111.

Parthasarthy, R., Sethi, S.P. (1993), Relating Strategy and Structure to Flexible: Automation: A Test of Fit and Performance Implications, Strategic Management Journal, 14, 529-549.

Pearce, J.A. Robinson, R.B.. (1985), Strategic Management: Strategy Formulationand Implementation, Irwin, Homewood, IL. 
Perrow, C. (1986), Complex Organizations: A Critical Essay, 3rd edition, Random House, New York.

Podsakoff, P.M., Organ, D.W. (1986), Self-Reports in Organizational Research:

Problems and Prospects, Journal of Management, 12, 531-544.

Porter, M.E. (1980), Competitive Strategy: Techniques for Analyzing Industries and Competitors. The Free Press, New York.

Porter, M.E. (1983), The Technological Dimension of Competitive Strategy, Research on Technological Innovation. Management and Policy: A Research Annual. Rosenbloom R.S. and Burgelman, R.A. (eds), JAl Press, Greenwich, CT.

Porter, M.E. (1985), Competitive Advantage: Creating and Sustaining Superior Performance, The Free Press, New York.

Porter, M.E. (1990). The Competitive Advantage of Nations, MacMillan, London.

Powell, T.C. 11992), Organizational Alignment as Competitive Advantage, Strategic Management Journal , 13, 119-134.

Pugh, D.S., Hickson, D.J. Hinings, C.R., Turner, C. 11968), Dimensions of Organization Structure, Adrministrative Science Quarterly, 13, 65-91.

Randlesome, C. (1990), The Business Culture in the United Kingdom, in: Business Cultures in Europe, Randlesome, C. (ed), Butterworth-Heinemann, Oxford.

Reger, R.K., Huff, A.S. (1993), Strategic Groups: a Cognitive Perspective, Strategic Management Journal, 14, 103-124.

Robinson, R.B., Pearce, J.A. (1988), Planned Patterns of Strategic Behavior and their Relationship to Business-Unit Performance, Strategic Management Journal, 9, $43-60$.

Roth, K. (1992), International Configuration and Coordination Archetypes for MediumSized Firms in Global Industries, Journal of International Business Studies, 3. 533-549.

Samson, R., Brongers, E.B. (1993), De Toekomst van de Europese Arbeidsverhoudingen, ESB, 26-05-93.

Scherer, F.M. Ross, D. (1990), Industrial Market Structure and Economic

Performance, Houghton Mifflin Company, Boston.

Schoonhoven, C. (1981), Problems with Contingency Theory: Testing Assumptions Hidden within the Language of Contingency "Theory". Administrative Science Quarterly, 26, 349-377.

Schreyögg, G. (1980), Contingency and Choice in Organization Theory, Organization Studies, 1, 305-326.

Schroeder, D.M. (1990), A Dynamic Perspective of the Impact of Process Innovation upon Competitive Strategies, Strategic Management Journal, 11, 25-41.

Schuler, R.S. (1987a), Personnel and Human Resource Management Choices and Organizational Strategy, Human Resource Planning, 10, 1-17.

Schuler, R.S. (1987b), Personnel and Human Resource Management, West, St. Paul, MN. 
Schuler, R.S. (1990), Repositioning the Human Resource Function: Transformation or Demise?, Academy of Management Executive, 4, 49-60.

Schuler, R.S. (1992), Strategic Human Resource Management: Linking the People with the Strategic Needs of the Business, Organizational Dynamics, Summer, 18-32.

Schuler, R.S., Jackson, S.E. (1987), Organizational Strategy and Organization Level as Determinants of Human Resource. Practices, Human Resource Planning, 10, $125-141$.

Schwan, R. (1993), Organisationskonfigurationen und Interne Arbeitsmärkte: Eine Theoretisch Empirische Untersuchung von Arbeitsorganisationen im Zeichen Interner Arbeitsmärkte, Universitaire Pers Maastricht, Maastricht.

Scott, W.R. (1987a), Organizations: Rational, Natural and Open Systems, 2nd edition, Prentice-Hall, Englewood Cliffs, NJ.

Scott, W.R. (1987b). The Adalescence of Institutional Theory, Administrative Science Quarterly, 32, 493-511.

Segev, E. (1989), A Systematic Comparative Analysis and Synthesis of Two Business. Level Strategic Typologies, Strategic Management Journal, 10, 487-505.

Shan, W. (1990), An Empirical Analysis of Organizational Strategies by Entrepreneurial High Technology Firms, Strategic Management Journal, 11, 129-139.

Shibata, T. (1993), Sony"s Successful Strategy for Compact Discs, Long Range Planning, 26/4, 16-21.

Skinner, W. (1969), Manufacturing: Missing Link in Corporate Strategy, Harvard Business Review,47, 136-145.

Sluijs, van E., Hertog, de F. (1992), Praktijkverkenning Personeelswetenschappen, MERIT, Research Memorandum 92-027, Maastricht.

Smith, K.G., Guthrie, J.P., Chen, M. (1989), Strategy, Size and Performance, Organization Studies, 10, 63-81.

Snell, S.A., Dean, J.W. (1992). Integrated Manufacturing and Human Resource Management: A Human Capital Perspective, Academy of Management Journal, $35,467-504$.

Snell, S.A. Dean, J.W. (1994), Strategic Compensation for Integrated Manufacturing: The Moderating Effects of Jobs and Organizational Inertia. Academy of Management Journal, 5, $1109-1140$.

Snaw, C.C., Hambrick, D.C. (1980), Measuring Organizational Strategies: some Theoretical and Methodological Problems, Academy of Management Review. $5 / 4,527-538$.

Sorge, A. (1989), An Essay on Technical Change: Its Dimensions and Social and Strategic Context, Organization Studies, 10, 23-44.

Sorge, A. (1991), Strategic Fit and the Societal Effect: Interpreting Cross-National Comparisons of Technology, Organization and Human Resources, Organization Studies, 12, 161-190. 
Sorge, A. (1992), Human Resource Management in The Netherlands, Employee Relations, 14, 71-84.

Sorge, A., Hartmann, G., Warner, M., Nicholas, I. (1983), Microelectronics and Manpower in Manufacturing, Gower, Aldershot.

SPSS-X Users's Guide (1988), SPSS-X User's guide, 3rd edition, SPSS Inc., Chicago.

Stacey, R.D. (1993), Strategic Management and Organisational Dynamics, Pitman, London.

Storey, J. (1992), Developments in the Management of Human Resources, Blackwell, Oxford.

Sutton, J. (1991), Sunk Costs and Market Structure: Price Competition, Advertising and the Evolution of Concentration, MIT Press, Cambridge, MA.

Tayeb, M. (1993), English Culture and Business Organization, in: Management in Western Europe: Societv, Cuiture and Organization in Twelve Nations, Hickson, D.u. (ed), De Gruyter, Berlin.

Taylor, F.W. (1911), Scientific Management, Harper, New York.

Thijssen, J.G.L. (1988), Bedrijfsopleidingen als Werkterrein. Een Oriëntatie, Vuga Uitgeverij, Den Haag.

Thomas, J.B., Clark, S.M., Gioia, D.A. (1993), Strategic Sensemaking and Organizationall Performance: Linkages among Scanning, Interpretation, Action and Outcomes, Academy of Management Journal, 36, 239-270.

Thompson, J.D. (1967), Organizations in Action, McGraw-Hill, New York.

Tirole, J. (1988), The Theory of Industrial Organization, MIT Press, Cambridge, Mass.

Tyson, S. (1993), Human Resource Management in the United Kingdom, in: Human Resource Management in Europe, Tyson, S., Lawrence, P., Poirson, P., Manzolini, L., Vincente, C.S. (eds), Kogan Page, London.

Venkatraman, N. (1989), The Concept of Fit in Strategy Research: Toward Verbal and Statistical Correspondence, Academy of Management Review, 14, 423-444.

Venkatraman, N., Camillus, J.C. (1984), Exploring the Concept of "Fit" in Strategic Management, Academy of Management Review, 9, 513-525.

Venkatraman, N., Prescott, J.E. (1990), Environment-Strategy Coalignment: An Empirical Test of its Performance Implications, Strategic Management Journal, $11,1-23$.

Venkatraman, N., Vasudevan Ramanujam (1986), Measurement of Business Performance in Strategy Research: A Comparison of Approaches, Academy of Management Review, 11, 801-814.

Visser, J. (1989). The Coming Divergence in Dutch Industrial Relations, paper presented at the Eighth World Congress of International Industrial Relations Association, Brussels, September.

Visser, J. (1992), The Netherlands: The End of an Era and the End of a System, in: Industrial Relations in the New Europe, Ferner, A. and Hyman, R. (eds), Blackwell, Oxford. 
Vonderembse, M.A., White, G.P. 119911, Operations Management: Concepts, Methods and Strategies, 2nd edition, West Publishing, St. Paul, MN.

Weber, M. (1947 trans.). The Theory of Social and Economic Organization, Henderson. A.H., Parsons, T. ledsh. The Free Press, Glencoe, IL.

Wheelwright, S.C., Hayes, R.H. (1985), Competing through Manufacturing, Harvard Business Review, 99-108.

White, R.E. (1986), Generic Business Strategies, Organizational Context and Performance: An Empirical Investigation, Strategic Management Journal. 7. $217 \cdot 231$.

Whitley, R. (1992), The Comparative Analysis of Business Systems: Societies, Firms, Markets: The Social Structuring of Business Systems, in: European Business Systems: Firms and Markets in their National Context, Whitley, R. (ed), Sage Publications, London.

Williams, J. (1992), How Sustainable is Your Competitive Advantage? California Management Review, Spring, 29-51.

Witteloostuijn, van A. (1994a), Contexts and Environments, in: International Encyclopedia of Business and Management, Warner, M. (ed), Routledge. London.

Witteloostuijn, van A. (1994b). The Study of Competition and Cooperation, in: Market Evolution: Competition and Cooperation, Witteloostuijn, van A. (ed), Kluwer Academic publishers, Dordrecht.

Wolfs, G. (1992), Firm Internal Labour Markets in the Netherlands: A Contract Theoretical Approach, Universitaire Pers Maastricht, Maastricht.

Woodward, J. (1965), Industrial Organization. Theory and Practice, Oxford University Press, New York.

Wright, P., Knoll, M. Tu, H., Helms, M. (1991), Generic Strategies and Business Performance: an Empirical Study of the Screw Machine Products Industry, British Journal of Management, 2, 57.65.

Zahra, S.A., Covin, J.G. (1993), Business strategy, Technology Policy and Firm Performance, Strategic Management Journal, 14, 451-478.

Zammuto, R.F." O'Connor, E.J. 11992), Gaining Advanced Manufacturing Technologies" Benefits: The Roles of Organization Design and Culture, Academy of Management Review, 17, 701-728. 



\section{SUCCES OF FALEN VAN ORGANISATIES}

\section{Generieke en specifieke strategieën in Groot Brittannië en Nederland}

De beslissingen die ondernemingen nemen ten aanzien van concurrentiefactoren in hun omgeving, zijn een bepalende factor in de vorming van hun strategieën. Het succes van deze strategieën is echter afhankelijk van de mate van consistentie in de genomen beslissingen. Een onderneming functioneert alleen als een coherent geheel wanneer de betrokkenen in de verschillende delen binnen de organisatie weten hoe hun beslissingem elkaar beïnloeden - met andere woorden: wanneer de samenhang tussen de interne en externe aspecten van strategie bekend is.

In dit onderzoek zijn vier van deze aspecten nader bestudeerd. In de eerste plaats is de concurrentie omgeving van de onderneming onder de loep genomen. De concurrentie-amgeving is gedefinieerd als het geheel van concurrentiefactoren waarmee de onderneming in direct contact staat. Te denken valt hierbij aan de klanten, leveranciers, financiers, aandeelhouders en concurrenten. Het tweede aspect is de generieke strategie van de onderneming. De generieke strategie geeft aan op basis waarvan de organisatie binnen een specifieke produkt-marktcombinatie een voordeel tracht te behalen op de concurrenten. Dit is bijvoorbeeld mogelijk op basis van het produceren tegen de laagste kosten (kostenleiderschap) of het creëren van een in de ogen van de consument uniek produkt (produktdifferentiatie). Het derde en vierde aspect tenslotte omvatten de specifieke strategieën op het gebied van produktietechnologie en human resource management. Deze specifieke strategieën geven aan hoe de generieke strategie wordt geimplementeerd op genoemde functionele gebieden.

Het doel van dit onderzoek is meer inzicht te verkrijgen in de relaties tussen de concurrentie-omgeving, de generieke strategie en de specifieke strategieën op het gebied wan produktietechnologie en human resource management. Deze relaties zijn onderzocht in een steekproef van chemische en voedingsmiddelenbedrijven in Groot-Brittannië en Nederland. De belangrijkste vraag die aan het onderzoek ten grondslag ligt, is: Presteren bedrijven die een optimale afstemming van bovengenoemde aspecten hebben weten te realiseren beter dan bedrijven zonder deze coherentie?

In hoofdstuk 1 wordt het onderzoek in het theoretisch kader van de (neo)contingentietheorie geplaatst. De contingentietheorie is ontwikkeld in de jaren zestig als reactie op de universele benaderingen van organisatie-onderzoek waarin getracht werd regels en richtlijnen te ontwikkelen waaraan iedere organisatie ongeacht haar specifieke kenmerken - zou moeten voldoen om succesivol te kuninen 
opereren. In de contingentietheorie wordt expliciet erkend dat het succesvol functioneren van een bedriff wordt bepaald door contextuele factoren, zoals bijvoorbeeld de concurrentie-omgeving. De neo-contingentietheorie voegt hieraan de rol van het management toe, door te stellen dat de karakteristieken van een organisatie deels worden bepaald door omgevingskenmerken en deels door bewuste keuzes van het management.

Eén van de belangrijkste veronderstellingen die ten grondslag liggen aan de (neo)-contingentietheorie is dat er een optimale afstemming lofwell fit) moet bestaan tussen de omgeving, structuur en strategie van de organisatie om succesvol te kummen functioneren. Het in dit proefschrift beschreven anderzoek is gebaseerd op deze veronderstelling en past daarmee binnen het (neo)contingentiedenken. De toegevoegde waarde van deze studie ligt voornamelijk in de aard van de steekproef (die besproken wordt in hoofdstuk 2) en het feit dat meerdere interne kenmerken - te weten de produktietechnologie en human resource management - gerelateerd worden aan de concurrentie-omgeving en strategie.

in hoofdstuk 2 wordt de onderzoekopzet behandeld. Het onderzoek is uitgevoerd in het kader van een Europees project - de 'International Organizational Observatory' (100) - waaraan zeven Europese onderzoekinstituten deelnemen. Dit internationale kader heeft grotendeels de aard van de steekproef en de methode van dataverzameling bepaald. In Nederland hebben 14 bedrijven, voornamelijk werkzaam in de chemische en voedingsmiddelensector, deelgenomen aan het onderzoek. In Groot-Brittannië omvatte de steekproef 24 bedrijven, verdeeld over verschillende industrieën waaronder de chemie en voedingsmiddelensector. De data zijn verzameld met behulp van een door de 100 ontworpen gestructureerde vragenlijst. Deze vragenlijst is ingevuld tijdens interviews met leden van het managementteam wan de betrokken divisies of business units.

In hoofdstuk 3 wordt de relatie tussen de concurrentie-omgeving en de generieke strategie in de Britse en Nederlandse steekproef geanalyseerd. De kernvraag in dit hoofdstuk is: Is in de onderzochte industrieèn sprake van consistente amgeving-strategiecombinaties? De analyse vindt plaats in drie stappen. Stap één bestaat wit het analyseren van de concurrentie-omgeving van de betrokken ondernemingen. Deze blijkt effectief weer te geven door middel van twee dimensies. De eerste omgevingsdimensie beschrijft een glijdende schaal van een 'noodzaak tot kostenbeheersing' tot een 'noodzaak tot innovatie'. De tweede omgevingsdimensie bestaat uit een glijdende schaal van een "noodzaak tot intensieve marketinginspanningen' tot een 'noodzaak tot het minimaliseren van de marketinginspanningen'. Stap twee omvat het bepalen van de generieke strategie van de bedrijven, terwijl in stap drie de omgevingskenmerken worden gekoppeld aan het strategieprofiel. Voor de bedrijven in de Britse en Nederlandse steekproef blijkt een bepaald strategieprofiel inderdaad samen te hangen met bepaalde omgevingskenmerken. Wanneer de omgeving noodzaakt tot innovatie volgen bedrijven 
voornamelijlk prospector-, analyticus- of verdedigerstrategieën. Strategieën op het gebied van kostenleiderschap, kostenleiderschap gecombineerd met een nisoriëntatie en combinatiestrategieën van kostenleiderschap, produktdifferentiatie en nisoriëntatie komen voornamelijk voor in een omgeving die aanleiding geeft tot kostenbeheersing. In een amgeving waar het minimaliseren van de marketinginspanningen noodzakelijk is, komen vooral kostenleiderschap. kostenleiderschap gecombineerd met een nisoriëntatie en (technische) produktdifferentiatie voor, terwijl in een omgeving waar intensieve marketinginspanningen belangrijk zijn, bedrijven voornamelijk concurreren op basis van een prospector-s analyticus- of combinatiestrategie van produktdifferentiatie, kostenleiderschap en nisoriëntatie. In de meeste onderzochte bedrijven blijken de bestaande omgeving-strategiecombinaties consistent. In zes bedrijven binnen de chemische en voedingsmiddelenindustrie is dit niet het geval.

In hoofdstuk 4 wordt de relatie tussen de specifieke strategieen op het gebied van produktietechnologie, de concurrentie-omgeving en de generieke strategie geanalyseerd. De kernvraag in dit hoofdstuk is: is er sprake van consistente omgeving-strategie-technologiecombinaties in de onderzochte industrieën in Groot Brittannië en Nederland? De analyse vindt plaats in twee delen. In het eerste deel wordt onderzocht of de traditionele produktiecategorieèn van stukproduktie, massaproduktie en continu-procesproduktie moeten worden aangepast wanneer de ondernemingen geavanceerde produktietechnologieën zoals bijvoorbeeld CAD、 CAM of FMS hebben geimplementeerd. Aangezien de implementatie van geavanceerde produktietechnologieën leidt tot significante verschillen in perceptie van de produktieomgeving, worden de traditionele categorieën aangepast. Binnen de categorieën van massaproduktie en continuprocesproduktie is daarom een glijdende schaal opgesteld die het spectrum van weinig tot veel flexibiliteit in produktie en integratie tussen de produktiefasen beslaat. Op basis van deze 'verfijnde' categorieën zijn de produktiesystemen van de bedrijven opnieuw geclassificeerd. In het tweede deel worden de verfijnde produktiecategorieën aan de concurrentie-omgeving en de generieke strategie gerelateerd. De meerderheid van de bedrijven in de steekproef blijkt consistente omgeving-strategie-technologiecombinaties te bezitten.

In hoofdstuk 5 wordt de relatie tussen de specifieke strategieèn op het gebied van human resource management (HRM), de concurrentie-omgeving en de generieke strategie besproken. De overkoepelende vraag in dit hoofdstuk is: Zijn de strategieen op het gebied van HRM zodanig geformuleerd dat ze de consistentie van de aanwezige combinatie van omgeving en generieke strategie ondersteunen? Aangezien de institutionele context en cultuur van Groot-Brittannië en Nederland de interpretatie van de afzonderlijke HRM componenten in beide landen beïnvloeden, zijn vier typen HRM strategieën onderscheiden waarop de institutionele context en cultuur van het land minder directe invloed hebben. Deze vier typen - een 'echte' 
HRM strategie, een 'opgelegde' HRM strategie, een 'zichzelf ontwikkelende' HRM strategie en traditioneel personeelsmanagement - verschillen in de mate van integratie van HRM met de generieke strategie en de mate van decentralisatie van HRM beslissingen. Bij de meeste bedrijven in de steekproef blijkt de geformuleerde HRM strategie de aanwezige combinatie van omgeving en generieke strategie te ondersteunen. Van de vijf bedrijven zonder deze consistentie wordt een beneden gemiddeld bedrijfsresultaat verwacht.

In hoofdstuk 6 wordt de relatie tussen de specifieke strategieën op het gebied van produktietechnologie en human resource management besproken. Ook in dit hoofdstuk geldt als leidraad de vraag of consistente technologie-HRMcombinaties aanwezig zijn. Om dit te onderzoeken wordt eerst per geavanceerde produktiemethode geanalyseerd hoe de implementatie daarvan de produktieomgeving van de onderzochte bedrijven beïnvloedt. Vervolgens worden de gevolgen van deze invloeden voor de organisatie van het produktiewerk en het management van (produktie)personeel geanalyseerd. De introductie van geavanceerde produktiemethoden blijkt in massaproduktiebedrijven de grootste veranderingen te veroorzaken. Dit komt voornamelijk doordat de massaproduktie bedrijven menen dat de implementatie van geavanceerde produktiemethoden de integratie tussen de verschillende produktiefasen versterkt en de voorraden gereed produkt en onderhanden werk doen afnemen. Dit impliceert ook dat de gevolgen voor human resource management in massaproduktiebedrijven groter zijn dan in bedrijven met een continu-proces. In massaproduktiebedrijven neemt de produktie-omgeving immers sterker toe in complexiteit. Het is dan ook niet verrassend dat de enige twee bedrijven die niet over een consistente technologie-HRM-combinatie beschikken, gebruik maken van massaproduktie. In maar liefst vijf continuprocesondernemingen was zelfs sprake van een 'over'investering in HRM. Om een consistente technologie-HRM-combinatie te verkrijgen had hier traditioneel personeelsmanagement volstaan. In de overige bedrijven is, volgens de theorie, sprake van een consistente technologie-HRM-combinatie.

In hoofdstuk 7 wordt per Brits en Nederlands bedrijf in zowel de chemische als de voedingsmiddelenindustrie het aantal consistente en inconsistente afstemmingen tussen de externe en interne aspecten van strategie geïnventariseerd. Deze worden vervolgens gekoppeld aan het bedrijfsresultaat. De zes mogelijke combinaties - die in de voorgaande vier hoofdstukken uitgebreid zijn besproken - betreffen de afstemming tussen: i) de concurrentie-omgeving en de generieke strategie, ii) de specifieke strategie op het gebied van produktietechnologie en de generieke strategie, iii) de specifieke strategie op het gebied van produktietechnologie en de concurrentie-omgeving, iv) de specifieke strategie op het gebied van HRM en de generieke strategie, v) de specifieke strategie op het gebied van HRM en de concurrentie-omgeving en vil de specifieke strategieën op het gebied van produktietechnologie en HRM. Het bedrijfsresultaat is gemeten als 
het rendement op omzet. De hypothese dat bedrijven waar bovengenoemde combinaties een coherent geheel vormen, boven gemiddeld presteren wordt bevestigd. Opvallend is dat bedrijven die volgens de theorie teveel investeren in geavanceerde produktiemethoden en HAM (een consistente combinatie had dus ook met minder investeren kunnen worden bereikt) eveneens boven gemiddeld presteren.

In hoofdstuk 8 tenslotte, worden de voornaamste conclusies uit de voorgaande hoofidstukken samengevat. Dit gebeurt in drie delen: de algemene empirische bevindingen, de verschillen tussen Groot Brittannië en Nederland en de verschillen tussen de chemische en voedingsmiddelenindustrie. Naast een aantal methodologische overwegingen wordt tenslotte een aanzet tot verder onderzoek geformuleerd. 



\section{CURRICULUM VITAE}

Mariëlle G. Heijltjes is op 5 mei 1968 geboren te Heerlen. In 1985 slaagde zij voor het eindexamen Gymnasium B, waarna zij Economie ging studeren aan de Rijksuniversiteit Limburg te Maastricht. Gedurende haar studie werkte zij als studentassistent bij het Center for European Studies in Maastricht. Het studiejaar 1989 bracht zij grotendeels in de Verenigde Staten door, waar zij haar afstudeerstage liep bij Dow Chemical USA in Michigan en een semester participeerde in het MBA-programma van de Indiana University Business School. Na het behalen van haar doctoraal diploma in augustus 1990, trad zij als assistent-inopleiding in dienst bij de sectie Organisatie van de Rijksuniversiteit Limburg. Sinds februari 1995 is zij als universitair docent verbonden aan dezelfde sectie van de vakgroep Managementwetenschappen van de Rijksuniversiteit Limburg te Maastricht.

Mariëlle G. Heijltjes, born on May 5th 1968 in Heerlen, studied (business) economics at the University of Limburg in Maastricht (the Netherlands) from 1985 until 1990. In the context of the Masters curriculum, she spent most of 1989 in the United States as an intern at Dow Chemical USA in Michigan (three months) and as a student at the Indiana University Business School (five months). During her studies she also worked as an assistant for the Center for European Studies in Maastricht. After accomplishing her Masters degree in (business) economics, she joined the department of Organization and Strategy Studies at the Faculty of Economics and Business Administration of the University of Limburg in Maastricht to write her doctoral thesis. From February 1995 she works as an assistant professor in this department. 